\title{
NEVADA TEST SITE WETLANDS ASSESSMENT
}

RECEIVED

DEC 241997 0 SAI

May 1997

Submitted to

U.S. Department of Energy

Nevada Operations Office

Environmental Protection Division

P.O. Box 98518

Prepared by Bechtel Ilevada

Ecological Services

P.O. Box 98521

.Las Vegas, NV 89193-8521 


\section{DISCLAIMER NOTICE}

"This Report was prepared as an account of work sponsored by an agency of the U.S. Government. Neither the U.S. Government nor any agency thereof, nor any of their employees, makes any warranty or representation, express or implied, or assumes any legal liability or responsibility for the accuracy, completeness, or usefulness of any information, apparatus, product, or process disclosed, or represents that its use would not infringe privately owned rights. Reference herein to any specific commercial product, process, or service by trade name, trademark, manufacturer, or otherwise does not necessarily constitute or imply its endorsement, recommendation, or favoring by the U.S. Government or any agency thereof. The views and opinions of authors expressed herein do not necessarily state or reflect those of the U.S. Government or any agency thereof."

This report has been reproduced from the best available copy.

Available to DOE and DOE contractors from the Office of Scientific and Technical Information, Post Office Box 62, Oak Ridge, Tennessee 37831. (423) 576-8401:

Available to the public from the National Technical Information Service, U.S. Department of Commerce, 5285 Port Royal Road, Springfield, VA 22161. (703) 487-4650. 


\section{DISCLAIMER}

Portions of this document may be illegible in electronic image products. Images are produced from the best available original document. 


\title{
NEVADA TEST SITE WETLANDS ASSESSMENT
}

\author{
By \\ Dennis J. Hansen \\ Paul D. Greger \\ Cathy A. Wills \\ W. Kent Ostler \\ May 1997 \\ WORK PERFORMED UNDER \\ CONTRACT NO. DE-AC08-9NV11718
}

Submitted to

U.S. Department of Energy

Nevada Operations Office

Environmental Protection Division

P.O. Box 98518 


\section{ACKNOWLEDGMENTS}

The authors wish to thank the following individuals who made significant contributions to this report. Dan C. Steen and Derek B. Hall produced the GIS-generated figures in this report. Dodie M. Witham assisted with the literature review and data management. 


\section{CONTENTS}

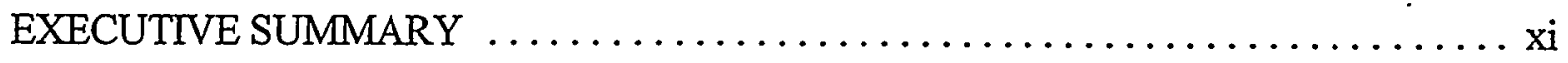

$1.0 \quad$ INTRODUCTION $\ldots \ldots \ldots \ldots \ldots \ldots \ldots \ldots \ldots \ldots \ldots \ldots \ldots \ldots \ldots \ldots \ldots \ldots$

1.1 Definition of a Wetland $\ldots \ldots \ldots \ldots \ldots \ldots \ldots \ldots \ldots \ldots \ldots \ldots \ldots \ldots \ldots \ldots \ldots$

$1.2 \quad$ Ecological Importance of Wetlands . . . . . . . . . . . . . . . . . . . 1

1.4 Need and Purpose for Wetlands Survey on the NTS ...............

1.5 Goals and Objectives of the NTS Wetlands Survey and Report .........

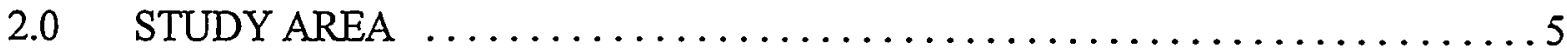

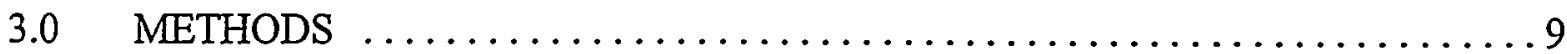

3.1 Literature Search to Identify Study Sites and Historical Use ..........9

3.2.1 Determining Wetland Site Coordinates ............... 10

3.2.2 Selecting Wetland Delineation Methods ................. 11

3.2.3 Delineating Wetland Boundaries ................... 12

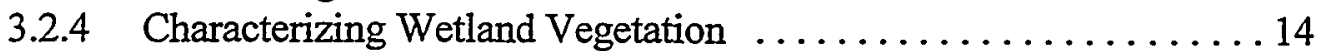

3.2.5 Characterizing Wetland Hydrology . . . . . . . . . . . . . . . . 15

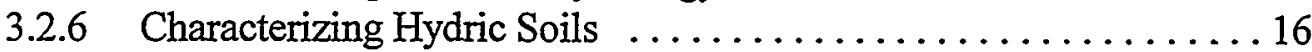

3.2.7 Delineating Jurisdictional Wetlands . . . . . . . . . . . . . . 18

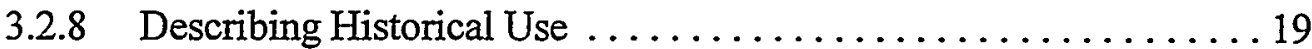

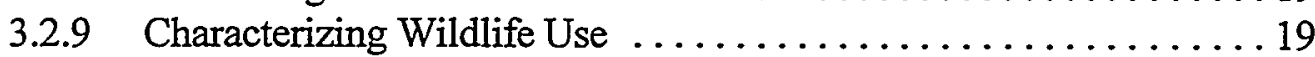

3.2.10 Photographing Wetlands ......................... 19

3.2.11 Creating a Wetlands Geospatial Database ............... 20

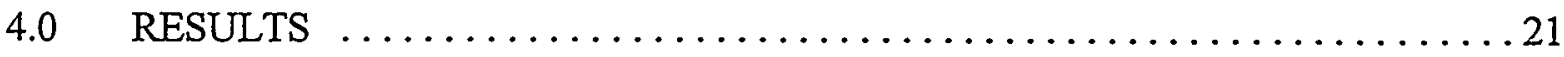

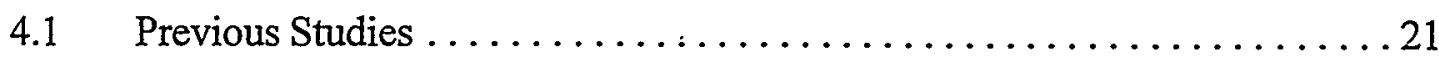

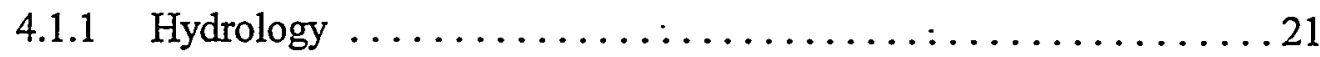

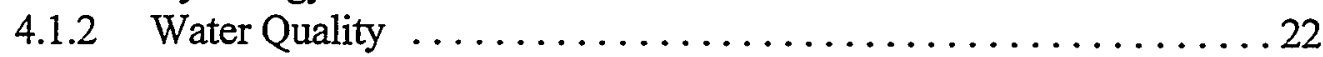

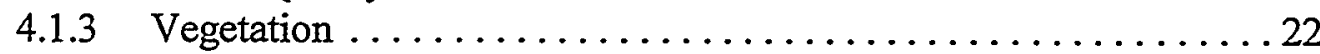

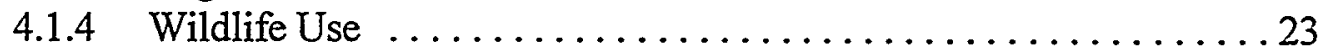

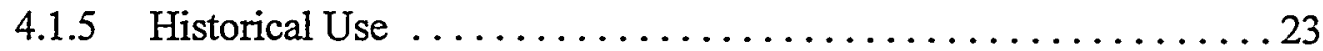

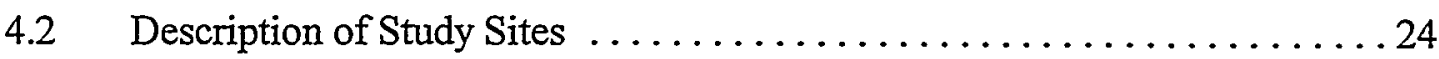

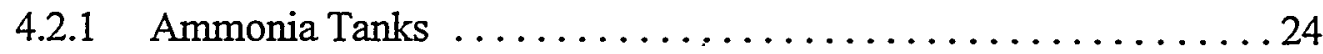

4.2.1.1 Site Description and Historical Use ............... 24

4.2.1.2 Hydrophytic Vegetation ....................24

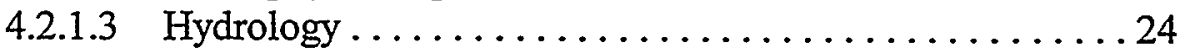

4.2.1.4 Hydric Soils . ......................... 27 


\section{CONTENTS}

4.2.1.5 Determination of Jurisdictional Status . . . . . . . . . 2 27

4.2.1.6 Wildlife Use ........................... 27

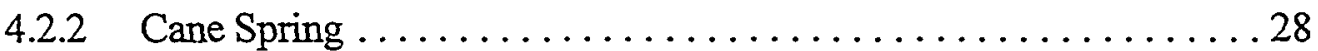

4.2.2.1 Site Description and Historical Use $\ldots \ldots \ldots \ldots \ldots 28$

4.2.2.2 Hydrophytic Vegetation ....................28 28

4.2.2.3 Wetland Hydrology and Water Quality ..............33

4.2.2.4 Hydric Soils . . . . . . . . . . . . . . . . . . . 33

4.2.2.5 Determination of Jurisdictional Status . . . . . . . . . 34

4.2.2.6 Wildlife Use ........................... 34

4.2.3 Captain Jack Spring $\ldots \ldots \ldots \ldots \ldots \ldots \ldots \ldots \ldots \ldots \ldots \ldots \ldots \ldots \ldots \ldots$

4.2.3.1 Site Description and Historical Use $\ldots \ldots \ldots \ldots \ldots . \ldots 34$

4.2.3.2 Hydrophytic Vegetation ....................... 36

4.2.3.3 Wetland Hydrology and Water Quality .............36

4.2.3.4 Hydric Soils ............................ 39

4.2.3.5 Determination of Jurisdictional Status . . . . . . . . . . 39

4.2.3.6 Wildlife Use .............................. 39

4.2.4 Cottonwood Spring $\ldots \ldots \ldots \ldots \ldots \ldots \ldots \ldots \ldots \ldots \ldots \ldots \ldots \ldots \ldots$

4.2.4.1 Site Description and Historical Use ............. 40

4.2.4.2 Hydrophytic Vegetation ................... 40

4.2.4.3 Wetland Hydrology and Water Quality $\ldots \ldots \ldots \ldots . . .43$

4.2.4.4 Hydric Soils ........................ 45

4.2.4.5 Determination of Jurisdictional Status . . . . . . . . . . 45

4.2.4.6 Wildlife Use ......................... 45

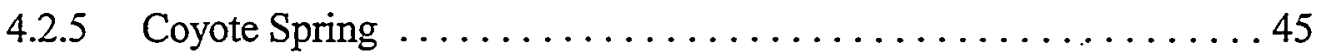

4.2.5.1 Site Description and Historical Use ............. 45

4.2.5.2 Hydrophytic Vegetation .................... 45

4.2.5.3 Wetland Hydrology and Water Quality ........... 48

4.2.5.4 Hydric Soils . ....................... 48

4.2.5.5 Determination of Jurisdictional Status . . . . . . . . . . 48

4.2.5.6 Wildlife Use ....................... 49

4.2.6 Fortymile Canyon Tanks ...................... 49

4.2.6.1 Site Description and Historical Use . . . . . . . . . . . . 49

4.2.6.2 Hydrophytic Vegetation ...................... . 49

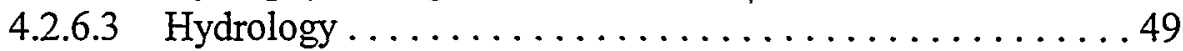

4.2.6.4 Hydric Soils ......................... 52 


\section{CONTENTS}

4.2.6.5 Jurisdictional Wetland Determination . . . . . . . . 52

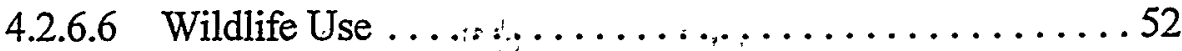

4.2.7 Gold Meadows Spring $\ldots \ldots \ldots \ldots \ldots \ldots \ldots \ldots \ldots \ldots \ldots \ldots \ldots \ldots$

4.2.7.1 Site Description and Historical Use $\ldots \ldots \ldots \ldots \ldots . \ldots 53$

4.2.7.2 Hydrophytic Vegetation ................ 53

4.2.7.3 Wetland Hydrology and Water Quality .......... 53

4.2.7.4 Hydric Soils . . . . . . . . . . . . . . . . 53

4.2.7.5 Determination of Jurisdictional Status . . . . . . . . 56

4.2.7.6 Wildlife Use .................... 56

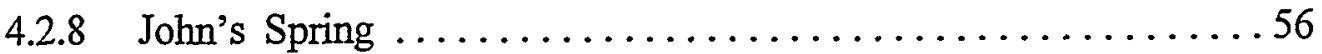

4.2.8.1 Site Description and Historical Use . . . . . . . . . . 56

4.2.8.2 Hydrophytic Vegetation . . . . . . . . . . . . . 59

4.2.8.3 Wetland Hydrology and Water Quality ........... 59

4.2.8.4 Hydric Soils ...................... 59

4.2.8.5 Determination of Jurisdictional Status . . . . . . . 60

4.2 .8 .6 Wildlife Use . . . . . . . . . . . . . . . . . 60

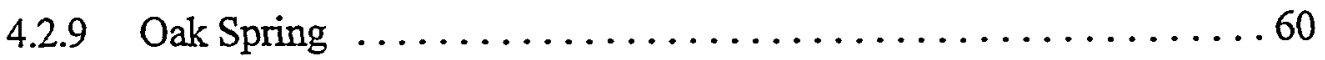

4.2.9.1 Site Description and Historical Use . . . . . . . . 60

4.2.9.2 Hydrophytic Vegetation ................. 61

4.2.9.3 Wetland Hydrology and Water Quality ........... 64

4.2.9.4 Hydric Soils . . . . . . . . . . . . . . . . 64

4.2.9.5 Determination of Jurisdictional Status . . . . . . . . 64

4.2 .9 .6 Wildlife Use ....................... 65

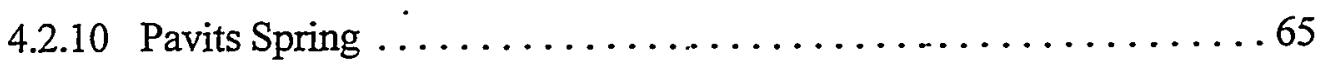

4.2.10.1 Site Description and Historical Use . . . . . . . . 65

4.2 .10 .2 Hydrophytic Vegetation . . . . . . . . . . . . 65

4.2.10.3 Wetland Hydrology And Water Quality . . . . . . . . 65

4.2 .10 .4 Hydric Soils . . . . . . . . . . . . . . . . 65

4.2.10.5 Determination of Jurisdictional Status . . . . . . . . 69

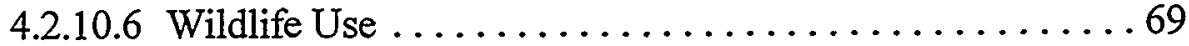

4.2 .11 Rainier Spring $\ldots \ldots \ldots \ldots \ldots \ldots \ldots \ldots \ldots \ldots \ldots \ldots \ldots \ldots \ldots \ldots \ldots . \ldots \ldots \ldots$

4.2.11.1 Site Description and Historical Use . . . . . . . . . 69

4.2 .11 .2 Hydrophytic Vegetation . . . . . . . . . . . . 72

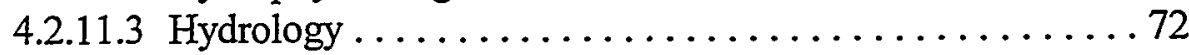

4.2 .11 .4 Hydric Soils $\ldots \ldots \ldots \ldots \ldots \ldots \ldots \ldots \ldots \ldots \ldots$ 


\section{CONTENTS}

4.2.11.5 Jurisdictional Wetland Determination .............73

4.2.11.6 Wildlife Use ......................... 73

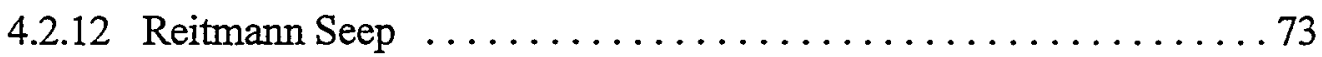

4.2.12.1 Site Description and Historical Use . . . . . . . . . . 73

4.2.12.2 Hydrophytic Vegetation . .................. 73

4.2.12.3 Wetland Hydrology and Water Quality . . . . . . . . . 76

4.2.12.4 Hydric Soils ........................ 76

4.2.12.5 Determination of Jurisdictional Status . . . . . . . . . 77

4.2.12.6 Wildlife Use $\ldots . \ldots \ldots \ldots \ldots \ldots \ldots . \ldots . \ldots . \ldots 77$

4.2.13 Rock Valley Tank ........................ 77

4.2.13.1 Site Description and Historical Use . . . . . . . . . . . 77

4.2.13.2 Hydrophytic Vegetation .................... 77

4.2 .13 .3 Hydrology $\ldots \ldots \ldots \ldots \ldots \ldots \ldots \ldots \ldots \ldots \ldots 77$

4.2.13.4 Hydric Soils ....................... 80

4.2.13.5 Jurisdictional Wetland Determination ............ 80

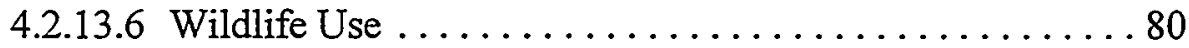

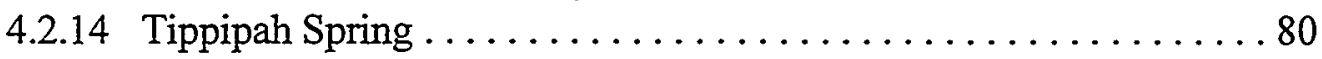

4.2.14.1 Site Description and Historical Use $\ldots \ldots \ldots \ldots . \ldots 80$

4.2.14.2 Hydrophytic Vegetation .................. 83

4.2.14.3 Wetland Hydrology and Water Quality . . . . . . . . . 83

4.2.14.4 Hydric Soils ........................ 88

4.2.14.5 Determination of Jurisdictional Status . . . . . . . . . . 88

4.2.14.6 Wildlife Use ........................... 89

4.2.15 Tongue Wash Tank ........................... 89

4.2.15.1 Site Description and Historical Use . . . . . . . . . . . . . 89

4.2.15.2 Hydrophytic Vegetation .................... 89

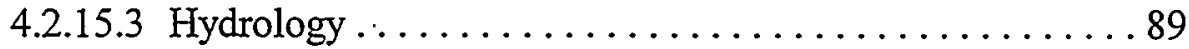

4.2.15.4 Hydric Soils . . . . . . . . . . . . . . . . . . . 89

4.2.15.5 Jurisdictional Wetland Determination ............ 89

4.2.15.6 Wildlife Use ....................... 92

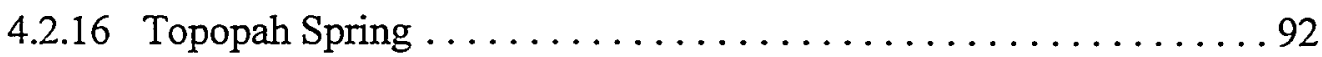

4.2.16.1 Site Description and Historical Use . . . . . . . . . . 92

4.2.16.2 Hydrophytic Vegetation ................... 92

4.2.16.3 Wetland Hydrology and Water Quality . . . . . . . . . . 98

4.2.16.4 Hydric Soils ........................... 98 


\section{CONTENTS}

4.2.16.5 Determination of Jurisdictional Status . . . . . . . . . . 98

4.2.16.6 Wildlife Use ............. $\ldots \ldots \ldots \ldots \ldots . .98$

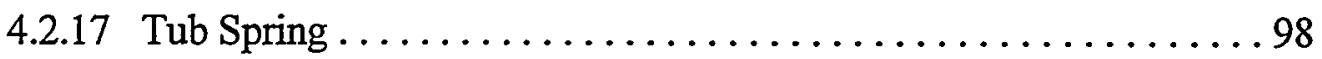

4.2.17.1 Site Description and Historical Use . . . . . . . . . . . . 98

4.2.17.2 Hydrophytic Vegetation .................... 101

4.2.17.3 Wetland Hydrology and Water Quality ........... 101

4.2.17.4 Hydric Soils ........................... 102

4.2.17.5 Determination of Jurisdictional Status ........... 102

4.2.17.6 Wildlife Use ........................ 102

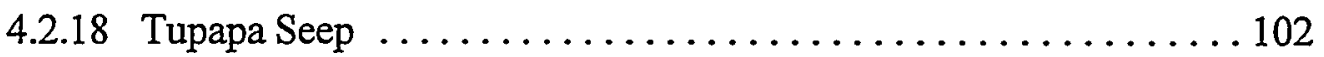

4.2.18.1 Site Description and Historical Use ............. 102

4.2.18.2 Hydrophytic Vegetation ................... 102

4.2.18.3 Wetland Hydrology and Water Quality ........... 102

4.2.18.4 Hydric Soils ........................... 105

4.2.18.5 Determination of Jurisdictional Status . . . . . . . . . 105

4.2.18.6 Wildlife Use ......................... 105

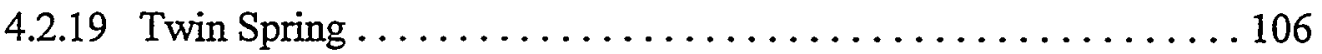

4.2.19.1 Site Description and Historical Use ............. 106

4.2.19.2 Hydrophytic Vegetation .................. 106

4.2.19.3 Wetland Hydrology and Water Quality ........... 109

4.2.19.4 Hydric Soils .......................... 110

4.2.19.5 Determination of Jurisdictional Status . . . . . . . . 110

4.2.19.6 Wildlife Use ....................... 110

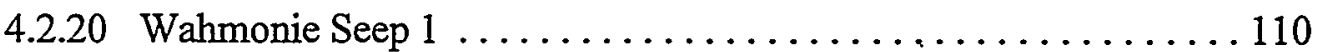

4.2.20.1 Site Description and Historical Use . . . . . . . . . . 110

4.2.20.2 Hydrophytic Vegetation ................... 110

4.2.20.3 Wetland Hydrology and Water Quality ........... 113

4.2.20.4 Hydric Soils . . . . . . . . . . . . . . . . . . . 113

4.2.20.5 Determination of Jurisdictional Status . . . . . . . . . . 114

4.2.20.6 Wildlife Use ........................ 114

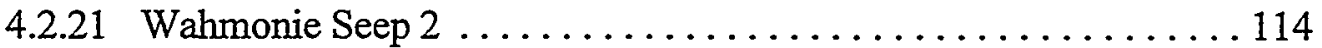

4.2.21.1 Site Description and Historical Use .............. 114

4.2.21.2 Hydrophytic Vegetation ..................... . 114

4.2.21.3 Wetland Hydrology and Water Quality ........... 114

4.2.21.4 Hydric Soils ........................... 117 


\section{CONTENTS}

4.2.21.5 Determination of Jurisdictional Status . . . . . . . 117

4.2 .21 .6 Wildlife Use . . . . . . . . . . . . . . . . 117

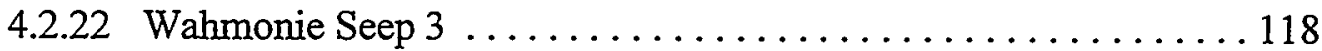

4.2.22.1 Site Description and Historical Use . . . . . . . . . 118

4.2.22.2 Hydrophytic Vegetation . . . . . . . . . . . . 118

4.2.22.3 Wetland Hydrology and Water Quality .... . . . . 118

4.2 .22 .4 Hydric Soils . . . . . . . . . . . . . . . . . 118

4.2.22.5 Determination of Jurisdictional Status . . . . . . . . 120

4.2 .22 .6 Wildlife Use . . . . . . . . . . . . . . . . 120

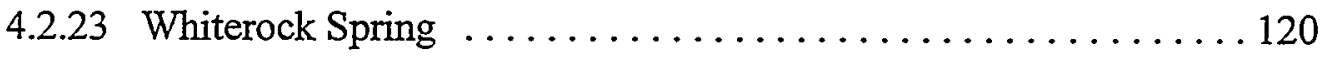

4.2.23.1 Site Description and Historical Use . . . . . . . . . 120

4.2.23.2 Hydrophytic Vegetation . . . . . . . . . . . . . . 122

4.2.23.3 Wetland Hydrology and Water Quality . . . . . . . . 122

4.2 .23 .4 Hydric Soils . . . . . . . . . . . . . . . . . . 126

4.2.23.5 Determination of Jurisdictional Status . . . . . . . . 126

4.2 .23 .6 Wildlife Use . . . . . . . . . . . . . . . . 126

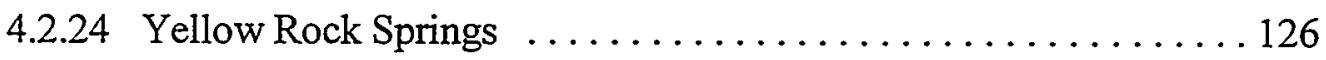

4.2.24.1 Site Description and Historical Use . . . . . . . 126

4.2.24.2 Hydrophytic Vegetation . . . . . . . . . . . . . 126

4.2.24.3 Wetland Hydrology and Water Quality . . . . . . . . . 129

4.2.24.4 Hydric Soils . . . . . . . . . . . . . . . . . . . 129

4.2.24.5 Determination of Jurisdictional Status . . . . . . . . . . 129

4.2 .24 .6 Wildlife Use . . . . . . . . . . . . . . . 130

4.2 .25 Yucca Playa Pond ......................... 130

4.2.25.1 Site Description and Historical Use . . . . . . . . . 130

4.2.25.2 Hydrophytic Vegetation . . . . . . . . . . . . . 130

4.2.25.3 Wetland Hydrology and Water Quality .......... 133

4.2.25.4 Hydric Soils . . . . . . . . . . . . . . . . 133

4.2.25.5 Determination of Jurisdictional Status . . . . . . . . 134

4.2 .25 .6 Wildlife Use . . . . . . . . . . . . . . . . . 134

4.2.26 Potential Man-Induced Wetlands . . . . . . . . . . . . . . . . 134

4.2.27 Waters of the United States . . . . . . . . . . . . . . . 135 


\section{CONTENTS}

5.0 DISCUSSION AND SUMMARY OF NTS WETLANDS $\ldots \ldots \ldots \ldots \ldots \ldots 137$

" 5.1 Jurisdictional Wetlands Determination ................... 137

$5.2 \quad$ Physical and Chemical Features ...................... 140

5.2.1 Physical Hydrology . . . . . . . . . . . . . . . . . . . . . . 140

5.2.2 Chemical Features ........................... 141

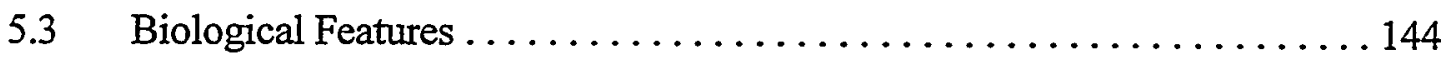

5.3.1 Wetland Plants ............................... 144

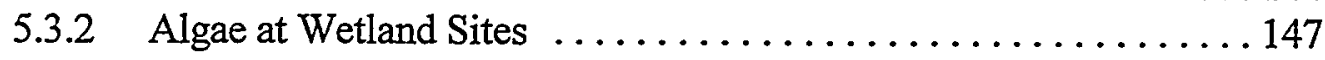

5.3.3 Wildlife Use .............................. 147

6.0 MANAGEMENT OF NTS WETLANDS $\ldots \ldots \ldots \ldots \ldots \ldots \ldots \ldots \ldots \ldots \ldots \ldots \ldots \ldots$

6.1 Protection as Important Biological Resources $\ldots \ldots \ldots \ldots \ldots \ldots \ldots 1$

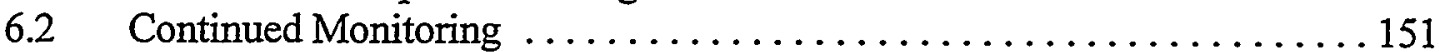

6.3 Identification and Evaluation of Other NTS Wetlands $\ldots \ldots \ldots \ldots \ldots 152$

6.4 Maintenance of Wetlands Geospatial Database ................. 152

6.5 Inclusion in Project Siting and Permitting Procedures ............ 152

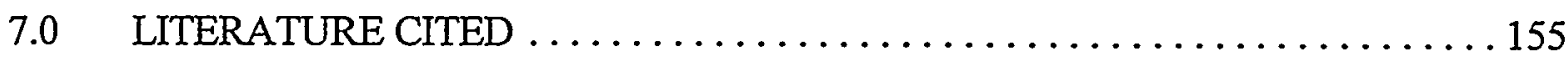

Appendix A List of Scientific and Common Plant Names ............... A-1

Appendix B Data Sheets for Routine Jurisdictional Wetland Determination ......... . B-1

Appendix C List of Algae and Algae-like Species Identified From Springs on the Nevada Test Site ..........................

Appendix D List of Animals Documented to Occur At NTS Wetlands and

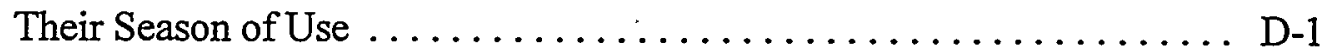

\section{List of Tables}

2-1 Attributes and location coordinates of NTS natural -water sources monitored in 1996 and 1997 . . . . . . . . . . . . . . . . . . . . 7

3-1 Steps for conducting an on-site routine wetland delineation survey . . . . . . 11

4-1 Ammonia Tanks wetland vegetation as surveyed on January 7, 1997 . . . . . 27

4-2 Cane Spring wetland vegetation as surveyed on June 19, $1996 \ldots \ldots \ldots \ldots 32$

4-3 Cane Spring wetland vegetation as surveyed on September $9,1996 \ldots \ldots \ldots 32$

4-4 Captain Jack Spring wetland vegetation as surveyed on June 19, 1996 . . . . . 39

4-5 Cottonwood Spring wetland vegetation as surveyed on December 12, 1996 . . 43

4-6 Coyote Spring wetland vegetation as surveyed on September 4, 1996 . . . . . 48

4-7 Fortymile Canyon Tanks wetland vegetation as surveyed on

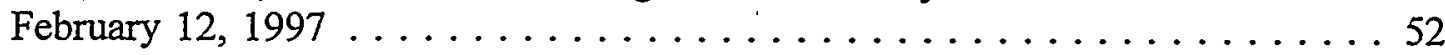




\section{CONTENTS}

\section{List of Tables}

4-8 Gold Meadows Spring wetland vegetation as surveyed on July 22, 1996 . . . . 56

4-9 John's Spring wetland vegetation as surveyed on December 12, $1996 \ldots \ldots$. . 60

4-10 Oak Spring wetland vegetation as surveyed on November 4, $1996 \ldots \ldots . .664$

4-11 Pavits Spring wetland vegetation as surveyed on September 4, 1996 . . . . . . 69

4-12 Rainier Spring wetland vegetation as surveyed on December 18, 1996 . . . . 72

4-13 Reitmann Seep wetland vegetation as surveyed on June 19, $1996 \ldots \ldots \ldots 76$

4-14 Rock Valley Tank wetland vegetation as surveyed on January 7, 1997 . . . . 80

4-15 Tippipah Spring wetland vegetation as surveyed on June $18,1996 \ldots \ldots \ldots 86$

4-16 Tippipah Spring wetland vegetation as surveyed on June 18, $1996 \ldots \ldots \ldots 87$

4-17 Tippipah Spring wetland vegetation as surveyed on June $18,1996 \ldots \ldots \ldots 88$

4-18 Topopah Spring wetland vegetation as surveyed on June $20,1996 \ldots \ldots$. . . 96

4-19 Topopah Spring wetland vegetation as surveyed on June 20, $1996 \ldots . . .997$

4-20 Tub Spring wetland vegetation as surveyed on November 7, 1996 . . . . . . . 101

4-21 Tupapa Seep wetland vegetation as surveyed on November $7,1996 \ldots \ldots$. . . 105

4-22 Twin Spring wetland vegetation as surveyed on December 12, 1996 . . . . . 109

4-23 Wahmonie Seep 1 wetland vegetation as surveyed on June $20,1996 \ldots \ldots .113$

4-24 Wahmonie Seep 2 wetland vegetation as surveyed on June 20, 1996 . . . . . 117

4-25 Wahmonie Seep 3 wetland vegetation as surveyed on June $20,1996 \ldots \ldots .120$

4-26 Whiterock Spring wetland vegetation as surveyed on June 18, 1996 . . . . . . 125

4-27 Whiterock Spring wetland vegetation as surveyed on June 18, 1996 . . . . . . 125

4-28 Yellow Rock Springs wetland vegetation as surveyed on December 19, 1996 . . . . . . . . . . . . . . . . . . . . . . . 129

4-29 Yucca Playa Pond wetland vegetation as surveyed on January 7, 1997 . . . . 133

5-1 Wetland hydrology data and jurisdictional wetland status of natural water sources surveyed June 1996 - February 1997 . . . . . . . . . . . . . . 139

5-2 Water quality measurements of natural water sources on the NTS surveyed June 1996 - February 1997 . . . . . . . . . . . . . . . . . 142

5-3 List of plants recorded at wetland sites on the NTS . . . . . . . . . 145

5-4 Number of vertebrate species recorded at each wetland study site on the NTS . . . . . . . . . . . . . . . . . . . . . . . 148

\section{List of Figures}

2-1 Location of NTS natural water sources monitored in 1996 and $1997 \ldots \ldots 66$

3-1 Form used to document field indicators for wetlands on the NTS . . . . . . 13

3-2 Form used to collect data on water quality and wildlife observations . . . . 17

4-1 Location of Ammonia Tanks . . . . . . . . . . . . . . . . . . . 25

4-2 Location and sketch of Cane Spring . . . . . . . . . . . . . 29

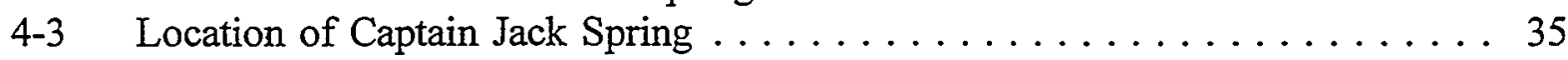

4-4 Location and sketch of Cottonwood Spring .............. 41

4-5 Location and sketch of Coyote Spring, Pavits Spring, and Tupapa Seep and sketch of Coyote Spring $\ldots \ldots \ldots \ldots \ldots \ldots \ldots \ldots \ldots$ 


\section{CONTENTS}

\section{List of Figures}

4 Location of Fortymile Canyon Tanks $\ldots \ldots \ldots \ldots \ldots \ldots \ldots \ldots \ldots$

4-7 Location of Gold Meadows Spring . . . . . . . . . . . . . . . . . 54

4-8 Location of John's Spring . . . . . . . . . . . . . . . . . . . 57

$4-9$ Location of Oak Spring . . . . . . . . . . . . . . . . 62

4-10 Location of Pavits Spring . . . . . . . . . . . . . . . 66

4-11 Location of Rainier Spring . . . . . . . . . . . . . . . 70

4-12 Location of Reitmann Seep . . . . . . . . . . . . . . . . . 74

4-13 Location of Rock Valley Tank ... . . . . . . . . . . . 78

4-14 Location and sketch of Tippipah Spring . . . . . . . . . . . . . . . 81

4-15 Location of Tongue Wash Tank ................... . 90

4-16 Location and sketch of Topopah Spring ................ 93

4-17 Location of Tub Spring . . . . . . . . . . . . . . . . 99

4-18 Location of Tupapa Seep . . . . . . . . . . . . . . . . . . . . . . 103

4-19 Location of Twin Spring . . . . . . . . . . . . . . . . . . . . 107

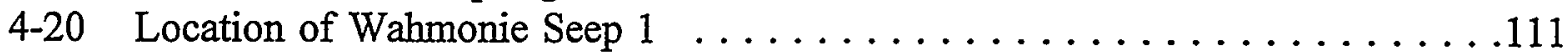

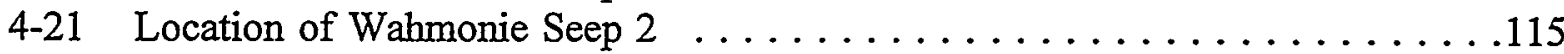

4-22 Location of Wahmonie Seep 3 . . . . . . . . . . . . . . . . . 119

4-23 Location and sketch of Whiterock Spring . . . . . . . . . . . . . 121

4-24 Location of Yellow Rock Springs . . . . . . . . . . . . . . . . . 127

4-25 Location and aerial photo of Yucca Playa Pond . . . . . . . . . . . . 131

5-1 Water sources identified as jurisdictional wetlands at the NTS $\ldots \ldots \ldots \ldots 138$

\section{List of Photographs}

4-1 Upland vegetation around the upper tank at Ammonia Tanks on

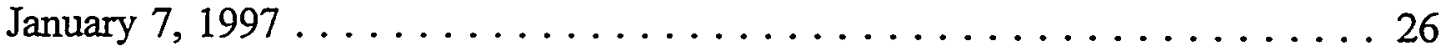

4-2 Lower tank at Ammonia Tanks looking northeast on January 7, $1997 \ldots \ldots 26$

4-3 Cane Spring area looking southeast on June 19, $1996 \ldots \ldots \ldots \ldots \ldots \ldots$

4-4 Cave pool and outflow at Cane Spring on June 19, $1996 \ldots \ldots \ldots \ldots . \ldots 30$

4-5 Reservoir at Cane Spring looking east in $1963 \ldots \ldots \ldots \ldots . \ldots . \ldots 31$

4-6 Dry reservoir at Cane Spring looking east on November 14, $1996 \ldots \ldots . .31$

4-7 Pool at Captain Jack Spring on September 10, $1996 \ldots \ldots \ldots \ldots \ldots \ldots$

4-8 Vegetation along spring outflow at Captain Jack Spring on

September 10,1996 ............................ 37

4-9 Horses at Captain Jack Spring in June 1989 . . . . . . . . . . . . . . . . . 38

4-10 Horse damage at Captain Jack Spring on November 21, $1988 \ldots \ldots \ldots . . .38$

4-11 Cottonwood Spring looking northeast on January 8, $1997 \ldots \ldots \ldots \ldots$. . . . 42

4-12 Vegetation on rock face at Cottonwood Spring on January $8,1997 \ldots \ldots$. . . 42

4-13 Spring pool at Cottonwood Spring on January 8, $1997 \ldots \ldots . . . \ldots \ldots 44$

4-14 Pool in rocky wash at Cottonwood Spring on January 8, $1997 \ldots \ldots \ldots \ldots 44$

4-15 Habitat at Coyote Spring on September 4, $1996 \ldots . . \ldots \ldots . . . \ldots 47$

4-16 Closeup of vegetation at Coyote Spring on September 4, $1996 \ldots . . . \ldots .44$ 


\section{CONTENTS}

\section{List of Photographs}

4-17 Habitat at Fortymile Canyon Tanks looking east on February 12, $1997 \ldots$. . . 51

4-18 Vegetation at Fortymile Canyon Tanks on February 12, 1997 . . . . . . . 51

4-19 Emergent vegetation in Gold Meadows Spring on June 10, $1992 \ldots \ldots \ldots$. . . 55

4-20 Dry pond at Gold Meadows Spring on December 10, $1990 \ldots . . . \ldots . .55$

4-21 John's Spring below the rocky outcrop looking north on February 24, 1997 . . 58

4-22 Wetland vegetation at John's Spring on February 24, $1997 \ldots \ldots \ldots \ldots . .58$

4-23 Vegetation at Oak Spring looking south on November 4, $1996 \ldots . . \ldots .663$

4-24 Closeup of wetland vegetation at Oak Spring on November 4, $1996 \ldots \ldots \ldots 63$

4-25 Habitat of Pavits Spring looking north on September 9, $1988 \ldots \ldots \ldots \ldots 67$

4-26 Wash vegetation around Pavits Spring looking northeast on

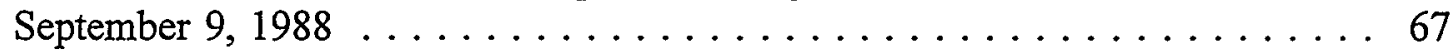

4-27 Pavits Spring pool with water on September 9, $1988 \ldots \ldots \ldots \ldots \ldots 68$

4-28 Dry pool at Pavits Spring on September 4, $1996 \ldots \ldots \ldots \ldots \ldots \ldots . \ldots 68$

4-29 Habitat at Rainier Spring looking north on February 20, 1997 . . . . . . . 71

4-30 Closeup of vegetation at Rainier Spring on February 20, 1997 . . . . . . . 71

4-31 Habitat of Reitmann Seep looking southwest on June 2, $1989 \ldots \ldots \ldots \ldots 75$

4-32 Pool at Reitmann Seep on June 2, $1989 \ldots \ldots \ldots \ldots \ldots \ldots$. . . . . . . 75

4-33 Habitat in the vicinity of Rock Valley Tank looking northwest on

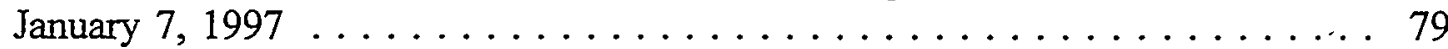

4-34 Tank opening (center) at Rock Valley Tank looking west on

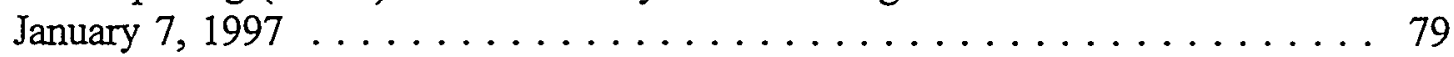

4-37 Tippipah Spring channel nearly dry, with drought-stressed vegetation, looking north on November $29,1990 \ldots \ldots \ldots \ldots \ldots \ldots \ldots$. . . 84

4-38 Upper reach of Tippipah Spring channel showing recovery of vegetation following drought, looking north on June $4,1992 \ldots \ldots \ldots \ldots$. . . 84

4-39 Middle reach of Tippipah Spring channel looking southwest on

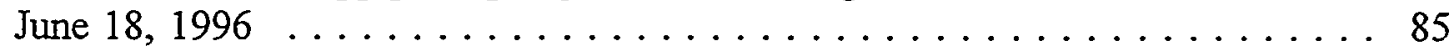

4-40 Lower reach of Tippipah Spring channel looking northwest on

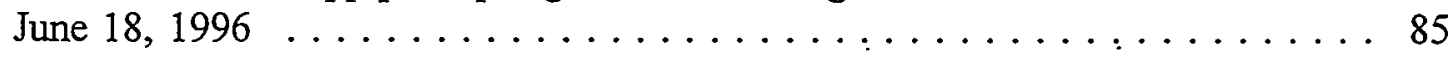

4-41 Cave opening at Tongue Wash Tank looking south on January 10, 1997 . . . 91

4-42 Tank inside cave at Tongue Wash Tank on January 10, $1997 \ldots \ldots$. . . . 91

4-43 Topopah Spring wetland area looking north on June 27, $1988 \ldots \ldots \ldots \ldots .94$

4-44 Vegetation of Topopah Spring cave pool on April 18, $1989 \ldots \ldots \ldots \ldots 94$

4-45 Outflow pipe at Topopah Spring on September 9, $1996 \ldots \ldots$. . . . . 95

4-46 Hillside meadow at Topopah Spring looking north on June 20, $1996 \quad \ldots \ldots 95$

4-47 Habitat at Tub Spring looking northwest on November 10,1988 . . . . . . . 100

4-48 Vegetation around Tub Spring on August 24, $1996 \ldots \ldots \ldots 0$

4-49 Habitat around Tupapa Seep looking north on September 4, 1996 . . . . . . 104

4-50 Closeup of vegetation at Tupapa Seep looking east on November 4, $1996 \quad$. 104

4-51 Habitat around Twin Spring looking east on January 8, $1997 \ldots \ldots \ldots$. . . 108

4-52 Wetland vegetation at Twin Spring looking north on January 8, $1997 \ldots \ldots 108$

4-53 Wahmonie Seep 1 looking north on June 20, $1996 \ldots \ldots \ldots \ldots 112$

4-54 Wahmonie Seep 2 looking south on June $20,1996 \ldots \ldots \ldots \ldots \ldots 112$ 


\section{CONTENTS}

\section{List of Photographs}

4-55 Wetland vegetation at Wahmonie Seep 2 looking south on June $20,1996 \ldots 116$

4-56 Wahmonie Seep 3 looking north on June 20, $1996 \ldots \ldots \ldots \ldots \ldots . .116$

4-57 Whiterock Spring with grazed vegetation looking north about $1968 \ldots \ldots \ldots 123$

4-58 Whiterock Spring without grazing looking north on June $18,1996 \quad \ldots \ldots \ldots 123$

4-59 Emergent vegetation in the east cave of Whiterock Spring on December $7,199.0$. . . . . . . . . . . . . . . . . . . . . . . . . 124

4-60 Surface pool at Whiterock Spring looking north on December $7,1990 \quad \ldots .124$

4-61 Habitat around Yellow Rock Spring looking southeast on January 29, 1997 . . 128

4-62 Drainage channel at Yellow Rock Spring looking southeast on January 29,1997 . . . . . . . . . . . . . . . . . . . . . . . . . 128

4-63 Emergent vegetation at Yucca Playa Pond looking north on January 7,1997 . . . . . . . . . . . . . . . . . . . . . . . 132

4-64 Drainage channel entering Yucca Playa Pond looking northwest on

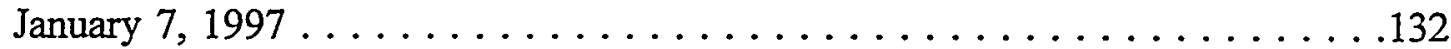




\section{ACRONYMS}

BN Bechtel Nevada

CWA Clean Water Act

DOE/NV U.S. Department of Energy, Nevada Operations Office

DRI Desert Research Institute

EA Environmental Assessment

EGIS Ecosystem Geographic Information System

EIS Environmental Impact Statement

EMAC Environmental Monitoring and Compliance Program

EPA U.S. Environmental Protection Agency

FAC Facultative wetland plants that occur in wetlands between 33 to $67 \%$ of the time

FACU Facultative upland plants that occur in wetlands less than $33 \%$ of the time

FACW Facultative wetland plants that occur in wetlands greater than 67 to $99 \%$ of the time

FWS U.S. Fish and Wildlife Service

GIS Geographic Information System

GPS Global Positioning System

ITIS Integrated Technical Information System

NEPA National Environmental Policy Act

NTS Nevada Test Site

NWI National Wetland Inventory

OBL Obligatory wetland plants that occur in wetlands greater than $99 \%$ of the time

PDOP Precision Dilution of Perception

RMP Resource Management Plan

TDS Total Dissolved Solids

TIRC Technical Information Resource Center

USACE U.S. Army Corps of Engineers

USDA U.S. Department of Agriculture

USGS U.S. Geological Service

UTM Universal Transverse Mercator 


\section{EXECUTIVE SUMMARY}

Twenty-five natural sources of water on the U.S. Department of Energy's (DOE) Nevada Test Site (NTS) were visited from June 1996 through January 1977. These water sources included 15 springs, 5 seeps, 4 tank sites (natural rock depressions that catch and hold : surface runoff), and 1 ephemeral playa pond. They are rare, localized habitats on the NTS that are important to regional wildlife and to isolated populations of water-tolerant plants and aquatic organisms. One purpose of the site visits was to identify those water sources which may be classified as "jurisdictional wetlands" and "waters of the United States" regulated under the Clean Water Act of 1977 (CWA). Section 404 of the CWA authorizes the U.S. Army Corps of Engineers (USACE) to issue permits for the discharge of dredged or fill material into waters of the United States, including wetlands. No field investigations on the NTS have been conducted in the past to identify those natural water sources which would be protected as rare habitats and which may fall under regulatory authority of the CWA.

This report identifies 16 NTS natural water sources that may be classified by the USACE as jurisdictional wetlands and 8 that may be classified as waters of the United States. Foreknowledge of these classifications will expedite project planning. If DOE proposes to impact jurisdictional wetlands or waters of the United States, a Section 404 CWA permit from USACE will be required. This report also identifies and summarizes previous studies of NTS natural water sources; describes the known physical, chemical, and biological features of these water sources; and identifies the current DOE management practices related to the protection of NTS wetlands.

Water sources on the NTS which were excluded as study sites were those created and sustained by artificial means. They include, for example, ponds adjacent to water wells that would dry up if the wells were shut down. Treatment ponds and lagoons also are not considered waters of the United States, and were excluded as study sites.

The method used to delineate wetland boundaries at each study site on the NTS was the Routine Wetland Determination method described in the U.S. Army Corps of Engineers Wetlands Delineation Manual (Environmental Laboratory, 1987). This method is used to delineate jurisdictional wetlands based on the presence of field indicators for three parameters: (1) hydrophytic (water tolerant) vegetation, (2) wetland hydrology, and (3) hydric soils. Data collected at each study site included a description of the wetland field indicators present at each site, the location and size of each wetland, observed wildlife usage, and photographs. At selected sites, cursory physical and chemical water quality data were also collected.

Sixteen of the 25 NTS water sources surveyed met the three required criteria to be considered jurisdictional wetlands. They included Cane Spring, Captain Jack Spring, Cottonwood Spring, Coyote Spring, Gold Meadows Spring, John's Spring, Oak Spring, Reitmann Seep, Tippipah Spring, Topopah Spring, Twin Spring, Wahmonie Seep 1, Wahmonie Seep 2, Wahmonie Seep 3, Whiterock Spring, and the vegetated margins of Yucca Playa Pond. 
Nine study sites had unvegetated pools of water which did not meet the criteria for jurisdictional wetlands, but which may be classified as waters of the United States. They include cave pools at four spring sites (Cane, Tippipah, Tub, and Whiterock springs), the pools of water in natural rock depressions at four sites (Ammonia Tanks, Fortymile Canyon Tanks, Rock Valley Tank, and Tongue Wash Tank), and the periodically inundated area of Yucca Playa Pond, the ephemeral pond that holds surface runoff from Yucca Lake playa.

All 16 of the study sites that may be classified as jurisdictional wetlands had field indicators for hydrophytic vegetation. Twenty-three species of plants had 10 percent or greater absolute cover at one or more study sites. These dominant species were used in determining if field indicators for hydrophytic vegetation were present at a site. Seventeen of the 23 dominant species were obligate wetland species or facultative wetland species.

Twenty-three of the 25 study sites had field indicators of wetland hydrology which included standing water, saturated soils, and evidence of periodic inundation such as water lines or dried algal mats. The only two sites which lacked these field indicators of wetland hydrology were Rainier Spring and Tupapa Seep. The source of water at most of the study sites is groundwater discharge from seeps and springs. Surface runoff from precipitation was found at Yucca Playa Pond and at the four tank sites.

Nineteen of the 25 study sites had field indicators for hydric soils which included saturated or inundated soils, dark-colored soils due to high organic matter content, and soil mottling. Field indicators were scarce at the 19 sites and were often inferred from site hydrology and past observations of surface water or saturated soils. Four of the six sites lacked saturated soils or other field indicators for hydric soils (Pavits Spring, Rainier Spring, Rock Valley Tank, and Tupapa Seep). Two of the six sites lacked soils altogether because they were located in bedrock (Fortymile Canyon Tanks and Tongue Wash Tank).

Eleven of the springs and seeps surveyed have surface flow of water all year long. These sites are Cane Spring, Captain Jack Spring, Cottonwood Spring, John's Spring, Oak Spring, Reitmann Seep, Tippipah Spring, Topopah Spring, Tub Spring, Twin Spring, and Whiterock Spring. The remaining 15 sites are ephemeral; they may dry up at some period of time during the year or during dry years. The sizes of the NTS wetlands are very small. With the exception of Tippipah Spring, Whiterock Spring, and Yucca Playa Pond, most were less than 300 square meters $\left(\mathrm{m}^{2}\right)\left(3,228\right.$ square feet $\left.\left[\mathrm{ft}^{2}\right]\right)$. They varied in size from less than $1 \mathrm{~m}^{2}\left(10.8 \mathrm{ft}^{2}\right)$ at Reitmann Seep to approximately $3,400 \mathrm{~m}^{2}\left(37,000 \mathrm{ft}^{2}\right)$ along the edges of Yucca Playa Pond, based on the area of hydrophytic vegetation. Water levels were generally shallow at all study sites, ranging from 3 to 200 centimeters $(\mathrm{cm})$ (1.2 to 78.7 inches [in.]). Flow rates of NTS springs measured during 1996 were very low, ranging from $0.0-3.0$ liters $/$ minute $(\ell / \mathrm{min})(0.0$ to 0.80 gallons $[\mathrm{gal}] / \mathrm{min})$.

Eighty-one species of vascular plants have been recorded in or near the NTS wetland sites based on the results of the 1996 and 1997 field surveys and on past NTS studies. Most of the species in NTS wetlands are forbs (33 species, 41 percent) followed by grasses, rushes, and sedges combined ( 30 species, 37 percent), and trees and shrubs combined (18 species, 22 percent). This is very different from the general flora of the NTS, where forbs make up approximately 74 percent of the total number of species. Grasses, rushes, and sedges 
make up only 12 percent while trees and shrubs make up 14 percent (Beatley, 1976). No plant species listed as threatened or endangered under the Endangered Species Act occur at any of the NTS natural water sources.

A total of 138 species of animals have been documented at NTS wetland sites, including various classes of animals such as mammals, birds, reptiles, and terrestrial insects. The largest group of vertebrates using NTS wetlands is birds (100 species). Passerine birds comprise the majority of birds recorded ( 80 species). Waterfowl use of NTS springs is negligible, probably due to the small surface areas of open water. Cane Spring and Yucca Playa Pond are the only natural NTS wetland sites that are known to attract migratory waterfowl. Many freshwater invertebrates occur in NTS natural water sources. They include nonparasitic nematodes (roundworms), oligochaetes (segmented worms), crustaceans (fairy shrimp, tadpole shrimp, clam shrimp, seed shrimp, copepods, water fleas), hydrobiid gastropods (springsnails), and chironomids (midge larvae). Use of wetland habitats on the NTS by federally listed threatened or endangered animals is negligible. Scat of the threatened desert tortoise have been found at the Rock Valley Tank site.

Executive Order 11990 (Federal Register, 1977) specifies that each federal agency "shall provide leadership and shall take action to minimize the destruction, loss or degradation of wetlands, and to preserve and enhance the natural and beneficial values of wetlands in carrying out the agency's responsibilities." DOE has taken several actions to ensure compliance with this Order. Data included in this report on NTS wetland locations, boundaries, sizes, animal usage, and presence of field indicators for jurisdictional wetlands classification will be used by DOE to better define the "natural and beneficial values" of NTS wetlands and to develop appropriate ecosystem management goals.

DOE has developed several tools to manage biological resources, including wetlands, on the NTS. These tools include a Geographic Information System (GIS) wetlands database which will be linked with other resource databases during development and implementation of land and facility use management goals. This report presents management goals specific for NTS wetlands that incorporate the intent of existing wetlands legislation, the principles of ecosystem management, and the interests of regional land managers and other stakeholders. Specific management goals presented in this report include (1) avoiding wetland impacts whenever possible, (2) minimizing all unavoidable wetland impacts, (3) restoring the biological integrity of wetlands if degradation occurs, and (4) preserving and enhancing the natural and beneficial values of NTS wetlands. Other recommendations pertaining to the management of NTS natural water sources are discussed in the final chapter of this report. 
This Page Intentionally Left Blank 


\subsection{INTRODUCTION}

\subsection{Definition of a Wetland}

There are 15 known springs and 5 known seeps on the U.S. Department of Energy's (DOE's) Nevada Test Site (NTS) in southern Nevada. Springs are sites where water flows from soil or rock creating noticeable surface flows. Seeps are sites where water also flows, but at much slower rates than springs resulting in saturated soils without noticeable surface flow. Other wet areas on the NTS include tanks (natural rock basins) and playas (plains of silt or mud, covered with water seasonally). Water flow and saturated soils on these sites may create habitat that supports hydrophytic vegetation or aquatic organisms, characteristic features of wetlands. The reference definition of a wetland is ". . . an ecosystem that depends on constant or recurrent, shallow inundation or saturation at or near the surface of the substrate. The minimum essential characteristics of a wetland are recurrent, sustained inundation or saturation at or near the surface and the presence of physical, chemical, and biological features reflective of recurrent, sustained inundation or saturation. Common diagnostic features of wetlands are hydric soils and hydrophytic vegetation. These features will be present except where specific physicochemical, biotic, or anthropogenic factors have removed them or prevented their development." (Nuclear Regulatory Commission [NRC], 1995).

\subsection{Ecological Importance of Wetlands}

Identifying and characterizing wetlands is important because of their value to local and regional ecosystems. Wetlands are known to have three major functions: (1) habitat maintenance and food web support; (2) short- and long-term storage of water; and (3) cycling of nutrients, removal of dissolved substances, and accumulation of inorganic sediments. The ecological and societal value of these functions include flood damage control, maintaining water quality, maintaining biodiversity, and providing habitat and forage for nongame and game species such as fish, fur-bearers, and waterfowl.

Wetlands within desert ecosystems are distinctly different.from the familiar examples of large marshlands, peatlands, and river floodplains within other physiographic regions of the nation. Desert springs and seeps are often too small in size to affect local or regional surface water flow or nutrient cycling. However, they do provide wildlife habitat, freestanding water, and forage which are regionally rare. They may increase the biodiversity of desert ecosystems, provide habitat and forage to migratory species passing through desert ecosystems, or help to determine the home range of resident wildlife species and the size of resident wildlife populations dependent on drinking water.

\subsection{Legal Status of Wetlands}

Wetlands are federally regulated throughout the nation on both private and public lands. The Clean Water Act (CWA) of 1977 (42 U.S. Code [USC] 1251, et seq. [amendments to the Federal Water Pollution Control Act of 1972]) was enacted to maintain and restore the chemical, physical, and biological integrity of the "waters of the United States." Section 404 of the Act authorizes the U.S. Army Corps of Engineers (USACE) to issue permits 
for discharging dredged or fill material into the waters of the United States, including wetlands. Since 1977, the USACE's regulatory authority has been expanded through numerous judicial decisions to include permitting for any disturbance to the size or water quality of wetlands, not just permitting for discharging dredged or fill materials into wetlands. The USACE (Federal Register [FR], 1982) and the U.S. Environmental Protection Agency (EPA) (FR, 1980) have jointly defined wetlands to aid in the delineation of "jurisdictional wetlands," i.e., those regulated under the CWA. Similar to the reference definition above, they define wetlands as "Those areas that are inundated or saturated by surface or ground water at a frequency and duration sufficient to support, and that under normal circumstances do support, a prevalence of vegetation typically adapted for life in saturated soil conditions. Wetlands generally include swamps, marshes, bogs, and similar areas."

The National Environmental Policy Act (NEPA) of 1969 (42 USC 4321) requires federal agencies to evaluate the impact of proposed actions on the environment. The broad intent of NEPA includes promoting "... efforts which will prevent or eliminate damage to the environment and biosphere and ... enrich the understanding of the ecological systems and natural resources important to the Nation ..." Documents produced in compliance with NEPA, including Environmental Assessments (EAs) and Environmental Impact Statements (EISs) routinely identify wetlands as unique components of the ecosystem which are described and discussed as part of the impact analysis.

In furtherance of NEPA, the Carter administration issued Executive Order 11990, Protection of Wetlands, in 1977 (42 FR 26961, May 24, 1977) to ". . a avoid to the extent possible the long and short term adverse impacts associated with the destruction or modification of wetlands and to avoid direct or indirect support of new construction in wetlands wherever there is a practicable alternative." This Order requires governmental agencies to minimize the destruction, loss, or degradation of wetlands and preserve and enhance the natural and beneficial values of wetlands in carrying out the agency's responsibilities, including managing federal lands and facilities.

\subsection{Need and Purpose for Wetlands Survey on the NTS}

No field investigations have been conducted in the past to identify all natural water sources on the NTS. Only nine springs have been routinely visited by NTS researchers such as hydrologists, biologists, and archeologists over the past 30 years. However, prior to 1996,12 other NTS seeps and springs and numerous ephemeral ponds which collect surface runoff on NTS playas remained scarcely studied and largely undocumented in available literature. These lesser-known natural water sources are equally rare and unique NTS habitats important to regional wildlife and localized populations of aquatic organisms and water-dependent vegetation. Their identification is essential for proper management and protection of natural resources on the NTS.

DOE/Nevada Operations Office (NV) has for the past two decades implemented an ecological monitoring program on the NTS to monitor various components of the ecosystem and to provide baseline data needed to identify and protect rare biological resources and federal- and state-protected plants and animals. The monitoring of wildlife 
use at selected NTS springs has been a long-term component of this program. This survey, aimed at identifying and describing all the natural water sources on the NTS, was conducted in 1996 and 1997 through DOE/NV's Ecological Monitoring and Compliance (EMAC) program.

The pertinent ecological data gathered on wetlands during this survey will be incorporated into an NTS resource management plan. DOE's Land- and Facility-Use Management Policy (O'Leary, 1994) is “. . . to manage all of its land and facilities as valuable national resources . . . based on the principles of ecosystem management and sustainable development. [DOE] will integrate mission, economic, ecologic, social, and cultural factors in a comprehensive plan for each site that will guide land and facility decisions .... This policy will result in land and facility uses that support the Department's critical missions, stimulate the economy, and protect the environment." The principles of ecosystem management is an approach to sustain the production of natural resources and the ecosystems on which those resources depend. This resource management plan will identify the rare and unique habitats of the NTS, such as wetlands, and how they will be managed based on ecosystem principles.

This wetlands survey is also helpful for compliance with NEPA. In the Final Environmental Impact Statement for the Nevada Test Site and Off-Site Locations in the State of Nevada (EIS) (DOE, 1996a), several alternative DOE activities proposed for the NTS over the next ten years were analyzed for their impacts on the existing environment, which included ten known springs and seeps. None of the proposed activities were expected to negatively affect these water sources. Information regarding all the natural water sources, however, even those that are more remote or are ephemeral, may be needed during NEPA impact analyses and siting suitability analyses for new NTS projects developed during, and well beyond, the next ten years.

Due to their federal regulatory status, this survey was designed to provide a preliminary delineation of jurisdictional wetlands that occur on the NTS. If a proposed project would impact a jurisdictional wetland, a permit from the USACE would need to be obtained before construction could begin. This survey also identifies those natural water sources which do not qualify as jurisdictional wetlands, but which may be protected as waters of the United States. Examples of waters of the United States are springs, seeps, tanks, and playas that do not support hydrophytic vegetation, but which have standing water for long periods. The permitting process for projects which may impact these waters is similar to that for jurisdictional wetlands. This survey of natural NTS water sources may expedite project siting, permitting, and construction by identifying up front those sites that may be regulated under Section 404 of the CWA.

\subsection{Goals and Objectives of the NTS Wetlands Survey and Report}

The goals and objectives of the 1996-1997 NTS wetlands field survey and this summary report are to

- identify and summarize all previous studies of NTS natural water sources;

- describe the physical, chemical, and biological features of these water sources; 
- determine if NTS natural water sources have the potential for classification as jurisdictional wetlands or waters of the United States; and

- identify current DOE management practices related to the protection of NTS wetlands 


\subsection{STUDY AREA}

The NTS is located in Nye County in southwestern Nevada. The NTS encompasses 3,496 square kilometers $\left(\mathrm{km}^{2}\right)\left(1,350\right.$ square miles [mi $\left.\left.{ }^{2}\right]\right)$ and is situated along the transition zone between the Mojave Desert and Great Basin Desert. The topography of the eastern and southern NTS is typical of the Great Basin, with numerous north/south-trending mountain ranges and intervening alluvial basins. In the northwestern portion of the NTS, the physiography is dominated by the volcanic highlands of Pahute and Rainier mesas. There are three primary valleys on the NTS: Yucca Flat, Frenchman Flat, and Jackass Flats. Elevation on the NTS ranges from less than 1,000 meters $(\mathrm{m})(3,281$ feet [ft]) above sea level in Frenchman Flat and Jackass Flats to about 2,340 m (7,600 ft) on Rainier Mesa.

Both Yucca Flat and Frenchman Flat are closed basins, while Jackass Flats is open with surface water drainage via Fortymile Wash into Amargosa Valley southwest of the NTS. Streams on the NTS are ephemeral. Runoff results from snowmelt and from precipitation during storms that occur most commonly in winter. Localized summer thunderstorms can also produce runoff events. Much of the runoff quickly infiltrates into rock fractures or into the dry soils, some is carried down alluvial fans in arroyos, and some drains onto playas in Yucca and Frenchman flats where it may stand for weeks as lakes.

Elevation is the most obvious factor affecting the distribution of plant and animal communities on the NTS. Mojave Desert plant communities are found at lower elevations, Great Basin Desert plant communities at the higher elevations, and transitional communities are found in the bottom of closed basins.

There are 20 known springs and seeps, 4 tanks, and 1 ephemeral pond on the NTS which occur over a range of elevations and habitats (Figure 2-1, Table 2-1). Eleven of the springs are the only natural sources of perennial surface water on the NTS. These include Cane Spring, Captain Jack Spring, Cottonwood Spring, John's Spring, Oak Spring, Reitmann Seep, Tippipah Spring, Topopah Spring, Tub Spring, Twin Spring, and Whiterock Spring. Most water discharged from NTS springs and seeps travels only a short distance from the source before evaporating or infiltrating into the ground. In contrast, there are at least 23 man-made impoundments on the NTS (Greger and Romney, 1994a) which are sources of perennial surface water. Most of these reservoirs are scattered through the valley bottoms.

The only biological communities on and around the NTS that are not widespread are those associated with the natural wetlands and man-made water sources. Many of the birds on the NTS, including almost all of the waterfowl and shorebirds; use the playas in Frenchman and Yucca flats, artificial ponds at springs, and sewage lagoons during their migration or during winter (Hayward et al., 1963). Bats have been observed feeding and drinking at one natural spring and at five man-made ponds on the NTS and often seek food and water at these water sources (Bechtel Nevada [BN], 1996). The distribution of about 60 wild horses (Equus caballas) living on or near Rainier Mesa appear to be directly related to the location of natural and man-made ponds (Greger, 1995).

A more detailed description of the physiography, geology, climate, and vegetation of the NTS has been presented in Beatley (1976) and O'Farrell and Emery (1976). 


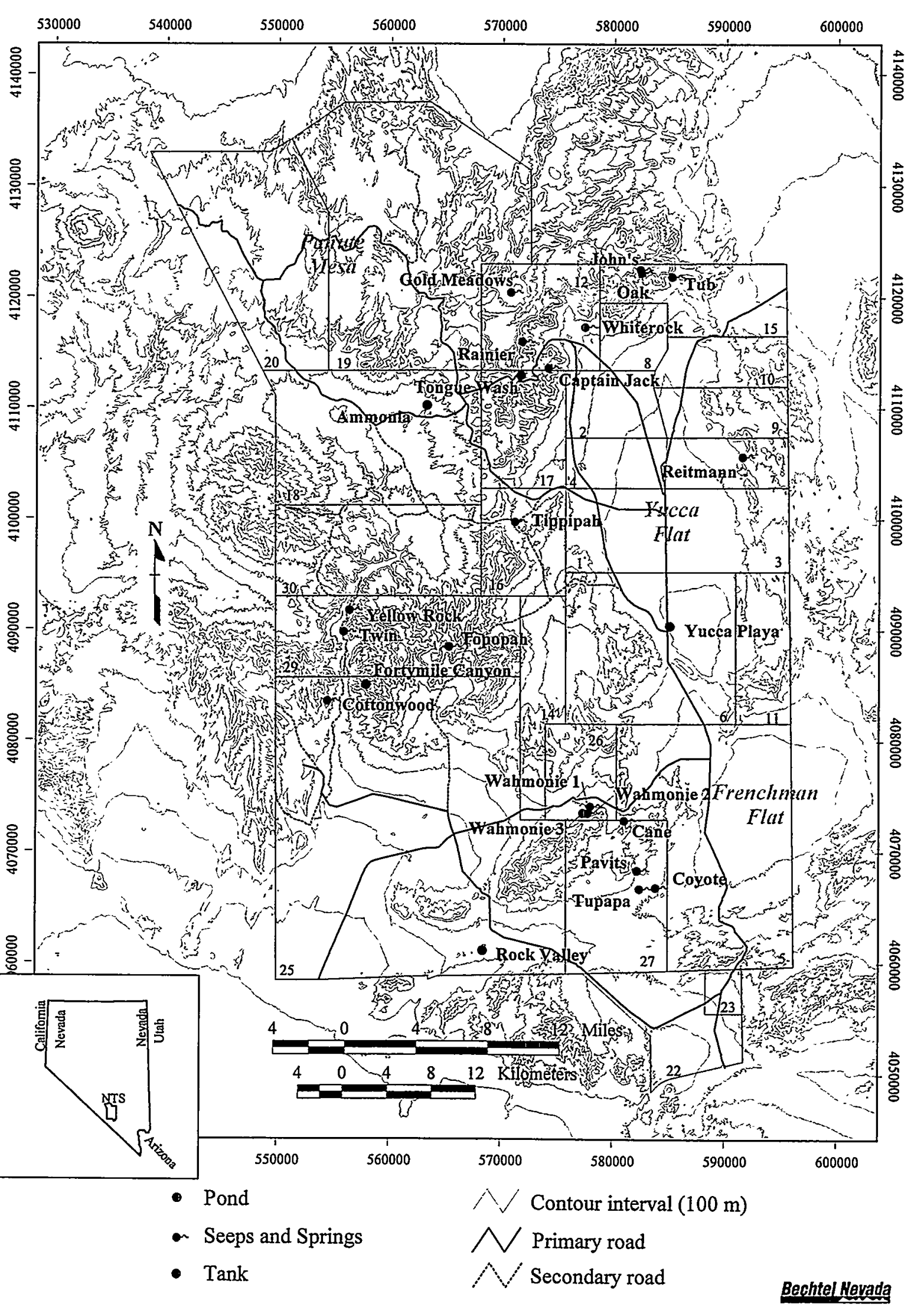

Figure 2-1 Location of NTS natural water sources monitored in 1996 and 1997 
Table 2-1 Attributes and location coordinates of NTS natural water sources monitored in 1996 and 1997

\begin{tabular}{|c|c|c|c|c|c|c|}
\hline Water Source & $\begin{array}{l}\text { NTS } \\
\text { Area }\end{array}$ & $\begin{array}{c}\text { Elevation } \\
(\mathrm{m})\end{array}$ & Habitat type $e^{2}$ & Geology/Age & $\begin{array}{c}\text { UTM } \\
\text { Easting }\end{array}$ & $\begin{array}{c}\text { UTM } \\
\text { Northing }\end{array}$ \\
\hline Ammonia Tanks & 19 & 1615 & Sagebrush & Ash flow tuff/Miocene & 562850 & 4110240 \\
\hline Cane Spring & 5 & 1237 & Blackbrush & Lava flows/Miocene & 580750 & 4072641 \\
\hline Captain Jack Spring & 12 & 1792 & Pinyon-Juniper & $\begin{array}{l}\text { Ash fall tuff/Miocene- } \\
\text { Oligocene }\end{array}$ & 573834 & 4113579 \\
\hline Cottonwood Spring & 25 & 1292 & Rabbitbrush & $\begin{array}{l}\text { Rhyolitic lava flows-bedded } \\
\text { tuff/Miocene }\end{array}$ & 554045 & 4083726 \\
\hline Coyote Spring & 27 & 1085 & Creosote & Lava flows/Miocene & 583594 & 4066568 \\
\hline $\begin{array}{l}\text { Fortymile Canyon } \\
\text { Tanks }\end{array}$ & 25 & 1396 & Rabbitbrush & $\begin{array}{l}\text { Rhyolitic lavas-tuffaceous } \\
\text { beds/Miocene }\end{array}$ & 557500 & 4085000 \\
\hline $\begin{array}{l}\text { Gold Meadows } \\
\text { Spring }\end{array}$ & 12 & 2048 & Pinyon-Juniper & $\begin{array}{l}\text { Ash fall tuff/Miocene- } \\
\text { Oligocene }\end{array}$ & 570415 & 4120398 \\
\hline John's Spring & 15 & 1840 & Sagebrush-Oak & $\begin{array}{l}\text { Ash fall tuff/Miocene- } \\
\text { Oligocene }\end{array}$ & 582100 & 4122490 \\
\hline Oak Spring & 15 & 1783 & Sagebrush-Oak & $\begin{array}{l}\text { Ash fall tuff/Miocene- } \\
\text { Oligocene }\end{array}$ & 582208 & 4122209 \\
\hline Pavits Spring & 27 & 1203 & Creosote & Lava flows/Miocene & 581931 & 4068118 \\
\hline Rainier Spring & 12 & 1890 & Pinyon-Juniper & $\begin{array}{l}\text { Ash fall tuff/Miocene- } \\
\text { Oligocene }\end{array}$ & 571463 & 4116050 \\
\hline Reitmann Seep & 7 & 1402 & Blackbrush & Ash fall tuff/Miocene & 591278 & 4105578 \\
\hline Rock Valley Tank & 25 & 1048 & Creosote & $\begin{array}{l}\text { Limestone, } \\
\text { dolomites/Upper-Mid } \\
\text { Cambrian }\end{array}$ & 568070 & 4061000 \\
\hline Tippipah Spring & 16 & 1585 & Sagebrush & $\begin{array}{l}\text { Ash fall tuff/Miocene- } \\
\text { Oligocene }\end{array}$ & 570857 & 4099671 \\
\hline Tongue Wash Tank & 12 & 1950 & Pinyon-Juniper & Ash fall tuff/Miocene & 571360 & 4113050 \\
\hline Topopah Spring & 29 & 1774 & Blackbrush & Ash flow tuff/Miocene & 564973 & 4088339 \\
\hline Tub Spring & 15 & 1594 & Sagebrush & $\begin{array}{l}\text { Ash fall tuff/Miocene- } \\
\text { Oligocene }\end{array}$ & 584925 & 4121850 \\
\hline Tupapa Seep & 27 & 1140 & Creosote & Lava flows/Miocene & 582129 & 4066459 \\
\hline Twin Spring & 29 & 1310 & Rabbitbrush & Rhyolitic lavas/Miocene & 555484 & 4089984 \\
\hline Wahmonie Seep 1 & 26 & 1286 & Blackbrush & Lava flows/Miocene & 577679 & 4073923 \\
\hline Wahmonie Seep 2 & 26 & 1347 & Blackbrush & Lava flows/Miocene & 577471 & 4073319 \\
\hline Wahmonie Seep 3 & 26 & 1341 & Blackbrush & Lava flows/Miocene & 577044 & 4073349 \\
\hline
\end{tabular}


Table 2-1 (continued)

\begin{tabular}{|l|c|c|l|l|l|l|}
\hline \multicolumn{1}{|c|}{ Water Source } & $\begin{array}{c}\text { NTS } \\
\text { Area }\end{array}$ & $\begin{array}{c}\text { Elevation } \\
(\mathbf{m})\end{array}$ & Habitat type $^{\mathrm{a}}$ & \multicolumn{1}{|c|}{ Geology/Age $^{\mathrm{b}}$} & $\begin{array}{c}\text { UTM } \\
\text { Easting }\end{array}$ & $\begin{array}{c}\text { UTM } \\
\text { Northing }\end{array}$ \\
\hline Whiterock Spring & 12 & 1539 & Blackbrush & $\begin{array}{l}\text { Ash fall tuff/ Miocene- } \\
\text { Oligocene }\end{array}$ & 577099 & 4117282 \\
\hline $\begin{array}{l}\text { Yellow Rock } \\
\text { Springs }\end{array}$ & 30 & 1298 & Blackbrush & Rhyolitic lava flow/Miocene & 555979 & 4091944 \\
\hline Yucca Playa Pond & 6 & 1189 & Salt cedar & Alluvium/Holocene-Pliocene & 584805 & 4090584 \\
\hline
\end{tabular}

${ }^{2}$ Dominant perennial vegetation surrounding each site.

${ }^{b}$ Taken from Frizzell and Shulters (1990). 


\subsection{METHODS}

\subsection{Literature Search to Identify Study Sites and Historical Use}

To identify the study sites at which field surveys would be conducted, 30 U.S. Geological Service (USGS) 7.5-Minute Series quadrangle maps were examined for seep and spring sites and a literature search was conducted. Potential wetlands on Frenchman and Yucca flats were identified by examining aerial photographs and looking for vegetated sites on and along the edge of the playas. The literature search identified (1) names of natural water sources which were unnamed on the maps; (2) locations of springs, seeps, and tanks that were not found on the maps; and (3) pertinent studies and historical accounts of wetland sites on the NTS. Many sites that were located on maps or identified in available literature were specifically excluded from this study, including water sources that were created and are sustained by artificial means and would therefore be disqualified as both jurisdictional wetlands and waters of the United States. For example, many wells on the NTS have adjacent ponds that support hydrophytic vegetation and aquatic organisms, but they would dry up if the wells were shut down. Also, treatment ponds or lagoons, although they have standing water for long periods of time, are not waters of the United States as defined by the CWA.

Several internal databases were searched including the BN ecological library database and an annotated ecological bibliography for the NTS (O'Farrell and Emery, 1976). Searches were conducted by the DOE/NV Technical Information Resource Center (TIRC) using their in-house Tech-Lib library database, the Oak Ridge National Laboratory database named ITIS (Integrated Technical Information System), and the University of Nevada System library database. Other agencies and institutions which assisted in literature search efforts by providing bibliographies, references, and documents included Desert Research Institute (DRI), Las Vegas and the EPA, Las Vegas. Internet searches were conducted on DOE and USGS web site databases. The following key words were used in these searches: NTS, springs, wetlands, water quality, water chemistry, hydrology, groundwater, flow rates, and perched water table. Historic information on springs and seeps was collected using additional key words such as historic, prospectors, ranching, mining, prehistoric, artifacts, ethno-history, Native Americans, and cultural resources.

Subject matter experts employed by BN, DOE/NV, and DRI with experience in geology and hydrology were also contacted to find pertinent reports referencing NTS natural water sources. Also, all historical data files and reports created in support of ecological tasks conducted by DOE/NV through the EMAC were referenced to identify past plant or wildlife animal observations at NTS springs and seeps.

The results of the literature searches provided information on spring hydrology, water quality, wildlife use, species inventories, and documented anthropogenic disturbances. These data were summarized and presented in this report, along with the results of the field surveys conducted in 1996-1997. 


\subsection{Field Surveys}

Biologists conducted surveys at 25 natural water sources on the NTS (Figure 2-1, Table 2-1) from June 1996 through February 1997. Three seeps were discovered in the summer of 1996 during field surveys conducted to map desert tortoise (Gopherus agassizii) habitat on the NTS. These seeps were not identified on USGS maps or in the available literature. They are located in washes south of Cane Spring Road in Area 26 and are referred to in this report as Wahmonie Seep 1, 2, and 3 (Figure 2-1).

Field surveys were conducted in coordination with other field and office tasks supported by DOE/NV. Therefore, not all springs were surveyed at the same time and many were visited multiple times. In June, biologists visited ten sites: Cane Spring, Captain Jack Spring, Reitmann Seep, Tippipah Spring, Topopah Spring, Tub Spring, Whiterock Spring, and Wahmonie Seep 1, 2, and 3. In July, Gold Meadows Spring and Reitmann Seep were visited. In September, biologists visited 12 sites: Cane Spring, Captain Jack Spring, Coyote Spring, Pavits Spring, Reitmann Seep, Tippipah Spring, Topopah Spring, Tongue

Wash Tank, Tub Spring, Tupapa Seep, Whiterock Spring, and Wahmonie Seep 1. In November, biologists visited five sites: Cane Spring, Oak Spring, Reitmann Seep, Tippipah Spring, and Tupapa Seep, and in December six sites were visited: Cottonwood Spring, Fortymile Canyon Tanks, John's Spring, Rainier Spring, Twin Spring, and Yellow Rock Springs. In January 1997, Ammonia Tanks, Rock Valley Tank, Yellow Rock . Springs, and Yucca Playa Pond were visited, and in February 1997, Fortymile Canyon Tanks, John's Spring, and Rainier Spring were visited.

Data were collected at each site to (1) identify the location and size of each wetland (i.e., delineate wetland boundaries); (2) describe the vegetation, hydrology, and soils to delineate jurisdictional wetland boundaries; (3) collect cursory physical and chemical water quality data; (4) document wildlife usage; and (5) document wetland habitat with photographs.

\subsubsection{Determining Wetland Site Coordinates}

The coordinates identifying the field location of each study site (Table 2-1) were recorded using hand-held Global Positioning System (GPS) units (Magellan ${ }^{\text {TM }}$ ProMark V). Coordinates were recorded as Universal Transverse Mercator (UTM) system values (Zone 11, North American datum) based on an average of 20 GPS readings and an average PDOP for all 20 readings of 10 or less. PDOP is defined as the precision dilution of perception and refers to the three-dimensional spacing of satellites. If satellites are properly spaced (indicated by a low PDOP, where PDOPs of six or less are recommended), the resulting coordinate readings are more accurate. The GPS coordinates for each site were not corrected for degradation by the U.S. Department of Defense and are believed to be accurate to within $100 \mathrm{~m}$ ( $328 \mathrm{ft}$ ) of the true location. The UTM coordinates of each NTS wetland site were then cross-checked with coordinates from the appropriate USGS 7.5-Minute Series quadrangle maps. 


\subsubsection{Selecting Wetland Delineation Methods}

The method used to delineate wetland boundaries at each site on the NTS was the Routine Wetland Determination method (Table 3-1) published in the U.S. Army Corps. of Engineers Wetlands Delineation Manual (1987 Manual) (Environmental Laboratory, 1987). There are two other wetland delineation methods, the use of National Wetland Inventory (NWI) maps prepared by the U.S. Fish and Wildlife Service (FWS) and the Comprehensive Wetland Determination method. The three methods vary in intensity of field effort and their applicability to the NTS.

Table 3-1 Steps for conducting an on-site routine wetland delineation survey

- Locate the project area

- Determine whether an atypical situation exists

- Identify the plant community types

- Determine whether normal environmental conditions are present

- Select representative observation points

- Characterize each plant community type

- Record indicator status of dominant species

- Determine whether hydrophytic vegetation occurs

- Apply wetland hydrologic indicators

- Determine whether wetland hydrology is present

- Determine whether soils must be characterized

- Dig a soil pit

- Apply hydric soil indicators *

- Determine whether hydric soils are present

- Make wetlands determination

- Determine wetland-nonwetland boundary

- Sample other transects and synthesize data

\footnotetext{
* Munsell color chart classifications were not applied in describing soils; only the presence or absence of mottling was recorded. Table is cited from the methods described in U.S. Army Corps of Engineers Wetlands Delineation Manual (Environmental Laboratory, 1987).
} 
NWI wetland maps provide classification and identification of general categories or types of wetlands (e.g., lake-based wetlands, riverine wetlands, palustrine wetlands, estuary wetlands, coastal wetlands, and marine or saltwater wetland types) (Cowardin et al., 1979). The only wetland type applicable to the NTS wetlands is the palustrine (inland) wetland type. Because of the scale size of the maps $(1: 24,000$ or $1: 100,000)$, many or most areas less than 2 hectares [ha] (5 acres [ac]) in size, such as those on the NTS, are not identified or distinguishable. Furthermore, these maps do not distinguish between jurisdictional and nonjurisdictional wetlands. Apparently, because of the small size and infrequent occurrence of wet areas on the NTS, no NWI maps have been produced, and hence, identification of wetlands or approximate wetland boundaries using these maps was not done.

The Comprehensive Wetland Determination method is used to delineate jurisdictional wetlands based on the presence of field indicators for three parameters: (1) wetland hydrology (flooded or saturated), (2) hydric soils (formed in a low-oxygen environment), and (3) hydrophytic (water tolerant) vegetation. The same three parameters are also used in the Routine Wetland Determination method; however, the Comprehensive Wetland Determination method uses more precise and quantitative methods of determining canopy cover such as line-point transects for estimating the canopy cover of dominant plants and for identifying hydrophytic vegetation.

Comprehensive determinations are only to be used when the project area is very complex (especially large wetlands) or when the determination requires rigorous documentation (e.g., if litigation is anticipated, or when the presence of one parameter such as hydrology, hydric soils, or hydrophytic vegetation is disputed). This method was not deemed appropriate because the NTS EIS did not identify any proposed actions that would impact NTS wetlands (DOE, 1996a), nor were there any disputes or controversies identified associated with the NTS wetlands.

The Routine Wetland Determination method delineates jurisdictional wetlands based on the presence of the same field indicators as does the comprehensive method. However, the vegetation sampling methods are not as stringent. Ocular estimates of canopy cover of dominant species of plants can be taken to characterize and identify hydrophytic vegetation. The Routine Wetland Determination method was selected for use because it is a rapid, yet effective and accepted method to identify jurisdictional wetlands. The data collected at each site to identify the presence of hydrophytic vegetation, wetland hydrology, and hydric soils were recorded on a data form (Figure 3-1) similar to the USACE Form 1 (Environmental Laboratory, 1987).

\subsubsection{Delineating Wetland Boundaries}

The aerial extent of each wetland was determined by identifying the boundary between wetland and upland vegetation. This boundary was determined by comparing plant species composition of the plant community in or immediately surrounding the seep or spring with plant species composition of the upland plant community more distant from the seep or spring. Changes in vegetation, in both species presence and abundance, were generally obvious (e.g., green vegetation versus brown vegetation), and transitions between the two 


\section{Routine Jurisdictional Wetland Determination}

Name:

Location:

Date:

\section{Hydrology}

Type: Seep ___ Spring ___ Pond Source: Natural Man-enhanced Date of construction/Period of flow:

Disturbance type (if any) and date:

Inundated: Yes _ No

Other field indicators:

Atypical situation:

Basis:

\section{Vegetation}

List 3 dominant species, percent cover in bold, in each vegetation layer (5 if only 1 or 2 layers are present)

\section{Trees}

\section{Species}

1.

2.

3.

4.

5.

Shrubs

1.

2.

3.

4.

5.

Herbs

1.

2.

3.

4.

5.

6.

7.

8.

9.

10.

Other field indicators:

Percentage of species that are OBL, FACW, and/or FAC:

Basis:

Hydric Soils

Field indicators:

Jurisdictional Wetland Determination : Wetland

Hydric Soils: Yes Nonwetland
Northing:
Wetland Unit:

UTM Coordinates Easting:
Detention basin Man-made
Stream Ephemeral
Mechanically contained Permanent Saturated: Yes No

Wetland hydrology: Yes Indicator Status

\% Cover
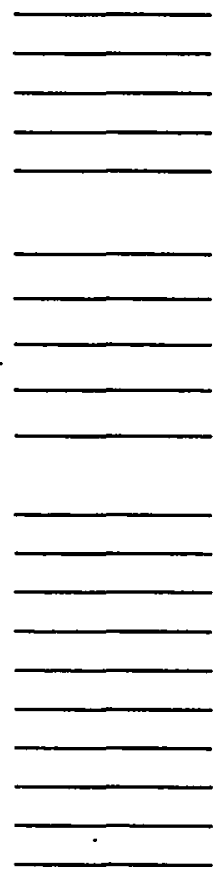

\%; Hydrophytic vegetation: Yes

-

Depth to saturation. No
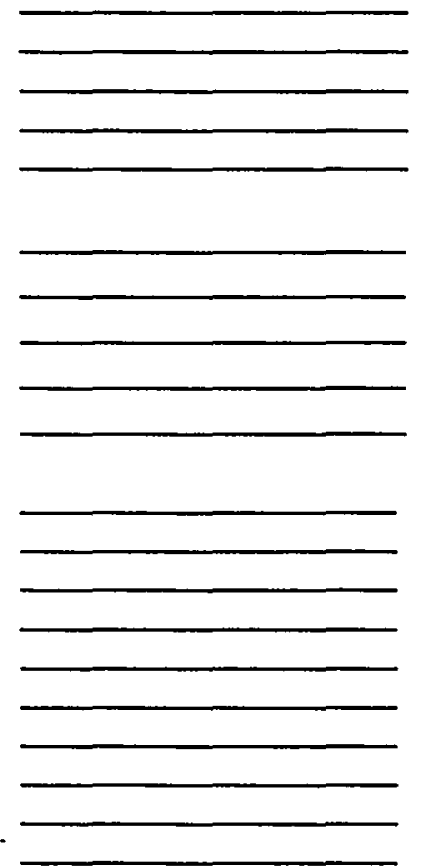
No 
community types were rather abrupt (e.g., less than $1 \mathrm{~m}$ [3.3 $\mathrm{ft}]$ wide). Wetland areas were identified by. the presence of plant species such as hydrophytic grasses, sedges, rushes, and shrubs that are characteristically restricted to moist habitats. Upland areas were identified by the presence of plant species characteristic of dry, arid soils. The boundaries of the wetland areas were then paced off to estimate the approximate dimensions of the wetland area.

To identify the boundaries of jurisdictional wetlands, in accordance with the Routine Wetland Delineation method, a further field analysis of plant communities within the wetland (non-upland) areas was required. The wetland area at each site was subdivided into zones. Areas with standing water, or evidence of historic standing water (e.g., presence of dried algae or waterlines), were distinguished as one zone. Transitional areas between the very wet zone and the dry uplands were divided into one or more zones based on changes in species composition. The NTS wetlands were very small, often less than $0.4 \mathrm{ha}(1 \mathrm{ac})$, and many only a few square meters in size. Therefore, usually only one wetland vegetation zone was identified per site. Within each major zone, a sample plot (also referred to as an "observation point") of approximately $1.5 \mathrm{~m}(5 \mathrm{ft}$ ) radius was selected. Plot size was smaller for small wetlands having less area. Tippipah Spring and Whiterock Spring were large wetlands where a mosaic of mesic habitats occurred or where a long linear wetland habitat occurred which had different vegetation characteristics downslope from the springhead. Within such larger wetland mosaics, boundaries of wetland zones that were patchy, discontinuous, or represented a changing linear corridor were sketched on a site map showing the relative position of site features. Approximate dimensions of each distinct wetland zone were recorded. The exact location of boundaries was difficult to document in the field because of a lack of aerial photos or maps with sufficient resolution or detail to permit determining their precise spacial locations.

\subsubsection{Characterizing Wetland Vegetation}

At each NTS site, one representative observation point per wetland zone was selected to examine field indicators for hydrophytic vegetation. The presence of hydrophytic vegetation is one of three parameters used to define a jurisdictional wetland. Vascular plants were identified and, using an ocular estimate (a visual projection of the plant canopy to the ground surface), were assigned an absolute percent cover estimate in each vegetation layer present (i.e., tree, shrub, herb). Plants in each vegetation layer with a 10 percent or greater cover value were defined as dominant species. All plants were classified as to their wetland status. To classify them, the National List of Plant Species That Occur in Wetlands Intermountain (Region 8) (Reed, 1996) was used. The plant names used are according to the National Plant Database (NRCS, 1996a). This list has assigned species to one of the following classes. A suffix of "-" or "+" is often used with the following codes to indicate that the plant is found on either the lower or higher ends of the range of probabilities that define each class. An asterisk $(*)$ following a regional indicator identifies tentative assignments based on limited information from which to determine the indicator status.

- UPL - Upland plants, occur almost exclusively in upland environments

- FACU - Facultative upland plants, occur in wetlands less than 33 percent of the time 
- FAC - Facultative wetland species, occur in wetlands between 33 to 67 percent of the time

- FACW - Facultative wetland plants, occur in wetlands between 67 to 99 percent of the time

- OBL - Obligatory wetland species, occur in wetlands greater than 99 percent of the time

- NI - No indicator, or not sufficient information to classify this species at this time

- NL - Not listed in the National List of Plant Species That Occur In Wetlands: Intermountain (Region 8) because they occur in wetlands less than 1 percent of the time

One additional classification was assigned to some plants found at NTS study sites:

- UNKN - Unknown status because plants lacked taxonomic characteristics needed to determine the genus and species.

Those wetland zones in which greater than 50 percent of the dominant plants are classified as $\mathrm{FAC}, \mathrm{FACW}$, or $\mathrm{OBL}$ were considered to possess hydrophytic vegetation per the USACE guidelines (Environmental Laboratory, 1987). In situations where there were equal numbers of dominant hydrophytic and upland species (e.g., four dominant hydrophytic and four dominant upland species), an alternative method for establishing dominance, recommended in a USACE memorandum (Williams, 1992), was used. This method was presented in a 1989 interagency manual produced by the USACE, FWS, and the U.S. Department of Agriculture (USDA) and uses a comparison of the proportion of canopy cover due to hydrophytic versus upland species. If the canopy cover at a site due to hydrophytic plants is greater than 50 percent, then the site would be considered as having field indicators for hydrophytic vegetation. The presence of filamentous algae and moss, although they are not vascular plants used to define wetlands, also were recorded when observed at study sites.

To conform to USACE convention, the Latin scientific names of plants are used throughout the text of this report. The common name of each plant species is presented once in the text the first time it is discussed, and thereafter the genus and species name of each plant is used. To assist the reader, Appendix A presents a table of both the scientific and common names of all plants presented in the text or tables of this report.

\subsubsection{Characterizing Wetland Hydrology}

Wetland hydrology encompasses all hydrologic characteristics of areas that are periodically inundated or have soils saturated to the surface for some duration during the growing season, usually about 12.5 percent of the growing season (Environmental Laboratory, 1987). At the NTS, this is about 14 to 21 days depending on elevation. The presence of natural surface water or saturated soils (i.e., not derived from human intervention or construction of such things as wells or sumps) in the late summer or fall was considered sufficient evidence of wetland hydrology at each NTS study site. Because 1996 was a rather dry year with little precipitation, most of the water at the springs and seeps was assumed to be from subsurface flows rather than from runoff. Data from past visits to these sites were also used as evidence of perennial supplies of spring water. 
At each wetland site, the maximum depth of standing water was measured with a meter stick. The areal extent of standing water was estimated by pacing off the area using a known stride. Depth to saturation was recorded as zero at all sites with pools or where the surface soils were saturated. The presence of saturated soils was determined by squeezing free water from a soil sample by hand or by observing water seeping into a 46-cm- (18-in-)-deep soil pit upon excavation. Soil pits were dug at very few study sites to avoid disturbing the sites. Therefore, depth to saturation was commonly not measured in wetland zones where surface soils were dry. One exception was in a wetland zone downslope of the springhead at Whiterock Spring. Here, a meter stick was inserted into a previously installed vertical pipe and the distance to water was recorded. At those NTS sites where standing water was absent, field indicators for wetland hydrology, including water marks on rocks and the presence of dried algae and other field indicators were recorded, as described in the 1987 Manual (Environmental Laboratory, 1987) (Figure 3-1).

Spring flow rate $(\ell / \mathrm{min})$ was measured at sites where water flowed through previously installed pipes (Reitmann Seep, Topopah Spring, Tub Spring, and Whiterock Spring) or where stream flow could be directed through a hand-held pipe (Cane, Captain Jack, Cottonwood, John's Oak, and Tippipah springs, and Fortymile Canyon Tanks) and measured in a graduated beaker per unit time. Flow rate measurements were replicated three or more times, and the average rate was recorded (Figure 3-2):

At 11 NTS sites, water quality parameters that may be important to aquatic animals and wildlife were measured by a simplified, rapid technique. These parameters included water temperature, dissolved oxygen, $\mathrm{pH}$, conductivity, and total dissolved solids (TDS). Handheld probes (Corning Checkmate System, Corning Scientific Products, Inc.) were used to take measurements at a depth of $5 \mathrm{~cm}$ (2 in). Readings were taken from one or more microhabitats (e.g., open pools, cave pools, man-made containers) where water was at least $5 \mathrm{~cm}(2 \mathrm{in})$ deep. Water quality probes were calibrated with known standard solutions prior to use and frequently checked against these standard solutions while in the

field. Automatic endpoint readings from the meter were used to determine when a particular value had stabilized. The stabilized values were recorded (Figure 3-2).

\subsubsection{Characterizing Hydric Soils}

A hydric soil is "A soil that is saturated, flooded, or ponded long enough during the growing season to develop anaerobic conditions that favor the growth and regeneration of the hydrophytic vegetation." (Environmental Laboratory, 1987). Biologists dug one or more soil pits $46 \mathrm{~cm}$ (18 in) deep at 7 of the 25 NTS study sites to identify indicators of hydric soils. The presence of organic matter was noted and the general thickness and texture of soils (e.g., rocky, gravelly) was recorded (Figure 3-1). Soil mottling was visually determined to be present or absent from the soil pits and also was recorded.

A complete soil analysis as prescribed by the Routine Wetland Determination method was not completed at the majority of the NTS wetland sites. For example, soil pits were not dug at 18 of the sites with smaller wetland zones, and a Munsell Color Chart (Munsell, 1992) was not used to classify mottling of mineral deposits in the soil horizons or in any dark chroma observed. A determination was made that digging a soil pit would create too much disturbance at small sites and that complete soil analyses would be unnecessary to 
Location: — Date:

Observer(s)

Location notes:

Water Temp $\left({ }^{\circ} \mathrm{C}\right)$

1)

2)

3)

Max Depth of surface water: Rel. Depth to water table: Water Temp $\left({ }^{\circ} \mathrm{C}\right)$

$$
\text { 1) }
$$

2)

3)

Max depth of cave water

Filamentous algae/moss Dissolved Oxygen (ppm)

Time: Start

Weather:

TDS (ppm)

1)

2)

3)

3)

Surface area of spring:

1) 1

2)

2)

3)

Location notes:

Finish

Cloud Cover:

\section{Cond $/(\mu \mathrm{S})$}

1)

2)

3)

Spring flow rate:

\section{TDS (ppm) \\ Cond $/(\mu \mathrm{S})$}

Dissolved Oxygen (ppm)

1)—_ 1)

2)

3)

Surface area of cave pool:
1) 1)

3)
1)____ 1)

2) 2) 2)

3)

3)
2)

Invertebrates

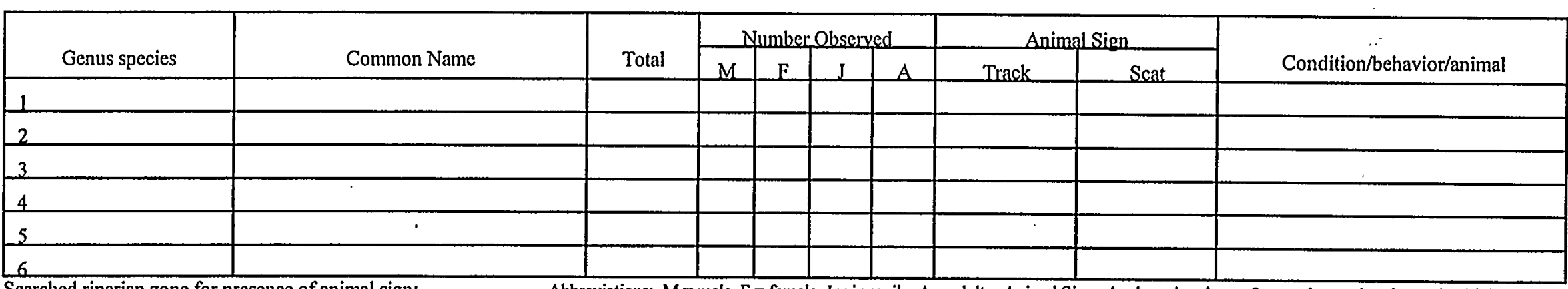

Searched riparian zone for presence of animal sign:

Abbreviations: $M=$ male, $F=$ female, $J=$ juvenile,$A=$ adult. Animal Sign: $I=$ low abundance, $2=$ moderate abundance, $3=$ high abundance. Cloud cover $=\%$ visual estimates; $0-25 \%=10 \overline{2}, 25=75 \%=$ moderate, $75-100 \%=$ high. Filamentous Algae: absent, minimal, abundant, or heavy growth.

Notes, UTMS, Slope, Drawings: 
delineate sites as jurisdictional wetlands. It is known that the USACE regards desert springs and seeps to be sites where "atypical situations" often occur in regards to the presence of hydric soil indicators (personal communication with Nancy Kang, USACE, Reno, Nevada Office, November 21, 1996). An atypical situation, as defined by the USACE, is an occasion where one or more field indicators for wetlands (i.e., hydrophytic vegetation, hydrology, hydric soils) have been sufficiently altered by natural events or by recent human activities to preclude their presence (Section F., Atypical Situations, in Environmental Laboratory, 1987). NTS wetlands that support hydrophytic vegetation and have surface hydrology are considered by the USACE to possess hydric soils, even though the field indicators for hydric soils are absent. Such sites would be classified by the USACE as atypical situations and would still be classified as jurisdictional wetlands.

Soils in sites that are ponded or saturated for a long duration (seven days to one month) or a very long duration (>one month) during the growing season (NRCS, 1996b) are also defined as hydric soils according to the 1987 Manual. The growing season is defined in the 1987 Manual as the portion of the year when soil temperatures at $50 \mathrm{~cm}(19.7 \mathrm{in})$ below the soil surface are higher than biologic zero $\left(5\right.$ degrees Celsius $\left[{ }^{\circ} \mathrm{C}\right] \cdot\left[41^{\circ}\right.$ Fahrenheit $[F]$ ) (for ease of determination, this period is usually approximated by the number of frost-free days). Because there had been only trace amounts of precipitation at the NTS prior to and during the fall of 1996, the presence of saturated soils or the presence of surface water, together with the presence of filamentous algae (which requires several weeks to grow), was interpreted as evidence to support the conclusion that the water must have persisted at least seven days and perhaps for several weeks or months. This water would have been present during a frost-free period (i.e., the growing season) and would therefore meet the criteria used to verify the presence of hydric soils.

\subsubsection{Delineating Jurisdictional Wetlands}

After field data about field indicators were collected, a determination was made as to which area(s) within each site would be considered jurisdictional wetlands regulated by the USACE. Wetland plant community zones that were dominated by hydrophytic vegetation, hydric soils, and that had wetland hydrology were considered jurisdictional wetlands. Because of the small size of the jurisdictional wetlands on the NTS, it was not always possible to accurately depict boundaries on site sketches or aerial photographs (i.e.,

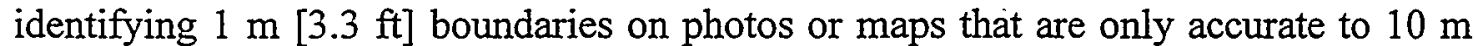
[32.8 ft]) or through narrative descriptions. The original intent of the wetland surveys was merely to identify NTS wetlands that had jurisdictional wetland areas that would require future field work to precisely identify boundaries. It is anticipated that if future development plans require disturbance of wetlands with areas considered jurisdictional, then the exact boundaries of the jurisdictional and nonjurisdictional areas would be surveyed and appropriate scale maps produced.

All boundaries of jurisdictional wetlands within this report should be considered approximate and managers directing future development activities within or near these areas should recognize that additional field work will be required to accurately identify jurisdictional boundaries. The size of these areas, and associated boundaries, probably 
fluctuate over time along with the amount of groundwater surfacing at each site. Because detailed aerial photos or surveys were not available, the relative location of areas (plant communities) that are considered jurisdictional wetlands is communicated through site sketches or narrative descriptions. The USACE usually conducts a site visit to verify field boundaries and site conditions, and locating jurisdictional boundaries may.be adjusted by " the USACE at the time of the site visit.

\subsubsection{Describing Historical Use}

Sites with prior historical use or natural events that obscure positive wetland field indicators require additional field techniques for delineating wetland boundaries. These altered sites are referred to as "atypical situations." Unique delineation procedures for these atypical situations are described in the 1987 Manual. These procedures attempt to determine site conditions prior to alteration by observing field evidence remaining at the site. Historical use at each potential wetland site was reviewed in the field and in the literature to determine if human alteration of a site occurred. Such alterations might include the removal of soils while attempting to improve water sources or while constructing stream channels. Each site was also evaluated to determine if natural events such as floods, fires, or landslides may have altered site conditions. Evidence of atypical situations, when found, is presented in the appropriate subsections of Section 4.2, "Site Description and Historical Use."

\subsubsection{Characterizing Wildlife Use}

Biologists recorded all sightings of animals, presence of tracks, and scat observed at each wetland site. On approach to a site, biologists first observed and counted any fleeing animals. Biologists then walked the complete perimeter of the vegetated wetland zones to locate any tracks and scat. Tracks and scat were identified with the aid of Murie (1974). The spring pools were also inspected for the presence of selected aquatic invertebrate groups (e.g., snails, ostracods, copepods). After vegetation, hydrology, soils, wildlife signs, and aquatic animal data were collected, a stationary observation point was chosen where birds, attracted to the wetland site, were observed and counted for a period of 30 minutes. All animal use data from these 1996 and 1997 surveys were recorded (Figure 3-2), compiled, and added to an existing historical database of similar data collected at NTS springs and seeps from 1988 to 1994.

The common names of animals are used throughout this report. The-Latin genus and species name for each animal is presented only once in the text the first time the animal is mentioned. Appendix D presents a table which includes both the common and scientific names of all animals mentioned in this report.

\subsubsection{Photographing Wetlands}

An historical database of over 550 photographs taken on and near the NTS wetland sites between 1960 and 1996 was searched. Recent photographs which best showed the boundary of the wetlands and the characteristic vegetation and hydrology of each site were retrieved and compared with historical photographs dating to 1960 . These comparisons were made to identify any trends in wetland attributes over time. Where needed, 
biologists took 35-mm photographs during these 1996 surveys to show the current conditions and specific microhabitats of NTS wetlands.

\subsubsection{Creating a Wetlands Geospatial Database}

ArcView GIS ${ }^{T M} 3.0$ software was used to organize information about NTS wetlands into a geospatial database. This database is part of a larger geospatial database developed by BN called the Ecosystem Geographic Information System (EGIS). EGIS operates on a Pentium $^{\oplus}$-based (166 MHZ, $32 \mathrm{Mb}$ RAM) IBM PC-compatible computer. EGIS was structured to access and display spatial information about NTS ecosystem resources and features such as UTM coordinates of site locations, topographic data, roads, NTS site boundaries, tabular site data, text files, digital photographs, other images (e.g., aerial digital photographs and satellite images), and biological data. Topographic data for the wetlands geospatial database were created from USGS Digital Elevation Model data sets. Road and site boundary data were created from NTS site facilities datasets. Wetland photographs $(10 \times 15 \mathrm{~cm}[4 \times 6 \mathrm{in}])$ were scanned at a file size ranging from 300 bytes to 3 megabytes and stored as digital image files in a tagged image file format (TIFF) format. Several GIS project files were created for the wetlands geospatial database and stored in computer files at BN's North Las Vegas Facility. Layouts (figures) were developed for each wetland site and printed on an Epson Stylus Pro $\mathrm{XL}^{\mathrm{TM}}$ printer. 


\subsection{RESULTS}

\subsection{Previous Studies}

The hydrologic conditions of the NTS have been studied extensively and have probably received more scientific scrutiny than any other area in Nevada. DOE/NV has funded studies of surface water and groundwater in order to best predict the impact of their missions on these resources and to develop project siting and operating criteria which will protect these resources. Some of these investigations have examined springs on and near the NTS and have provided some information on the physical hydrology, recharge and discharge rates, hydrochemistry, water quality, historical use, plant communities, and wildlife usage of NTS springs.

\subsubsection{Hydrology}

NTS springs are generally located in volcanic lavas and tuff formations of Miocene age (Table 2-1). Water flow derives from perched water tables in these formations (Moore, 1961; Ingraham et al., 1990). NTS springs are not believed to be restricted to any single lithologic unit (Clebsch, 1960), suggesting that they are fed by several different perched zones of saturation throughout the NTS. The area of any one perched aquifer may be only as large as a few square miles (Clebsch, 1960). Springs from perched water are characterized by highly variable discharge and by variable temperature, usually less than $21^{\circ} \mathrm{C}\left(70^{\circ} \mathrm{F}\right)$ (Winograd and Thordarson, 1975). No springs on the NTS emerge from the valley-fill or the lowercarbonate aquifers found on the floor of valleys in the region, such as Big Spring in Ash Meadows. That type of spring, in contrast to perched groundwater springs, represents discharge points of a regional zone of saturation and are characterized by high and uniform discharge and uniform temperatures, generally from $24^{\circ} \mathrm{C}$ to $35^{\circ} \mathrm{C}\left(75^{\circ} \mathrm{F}\right.$ to $\left.95^{\circ} \mathrm{F}\right)$ (Winograd and Thordarson, 1975).

Discharges from springs, seeps, and aquifers in the region range from less than one to several thousands of gallons per minute (DOE, 1996a). Recorded flow rates from springs and seeps at NTS are all very low, generally less than $10 \mathrm{l} / \mathrm{min}$ (2.6 gal/min) (Ball, 1907; Moore, 1961; Thordarson and Robinson, 1971; DOE, 1988; Lyles et al., 1990; Ingraham et al., 1991). Moore (1961) reported estimates of discharge rates for eight springs on the NTS taken from 1958 to 1960. The highest discharge rates were observed at Cane Spring (7.6-11.4 l/min [2-3 $\mathrm{gal} / \mathrm{min}])$ and Whiterock Spring (3.8-7.6 $\mathrm{l} / \mathrm{min}$ [1-2 gal/min]). The other six NTS springs (Captain Jack, Oak, Rainier, Tippipah, Topopah, and Tub) have recorded maximum discharge rates less than $1.7 \mathrm{l} / \mathrm{min}(0.4 \mathrm{gal} / \mathrm{min}$ ) (Moore, 1961; Lyles et al., 1990).

Cane and Whiterock springs are two of the most studied springs, and the variation in their flow rates over time has been examined. Between 1981 and 1988, discharges varied from 1.1 to $6.0 \mathrm{l} / \mathrm{min}$ (0.3 to $1.5 \mathrm{gal} / \mathrm{min}$ ) at Cane Spring and from 0.5 to $4.4 \mathrm{l} / \mathrm{min}(0.1$ to 1.2 $\mathrm{gal} / \mathrm{min}$ ) at Whiterock Spring (Ingraham et al., 1991; Lyles et al., 1990). Such changes in discharge rates are most likely affected by changes in the volume of local precipitation. Recharge of the perched water tables that feed NTS springs occurs by infiltration of rain or snowmelt through unsaturated, fractured rock. Two mechanisms of infiltration are 
thought to affect spring discharges: slow infiltration to the perched water table through unsaturated rock, and rapid infiltration through the rock fractures. During periods of moderate precipitation, water infiltrates slowly through the pores of the rock resulting in longer residence time of the recharging water and in reduced fluctuations in spring discharge rates. During large precipitation events, water infiltrates rapidly, primarily by fracture flow, allowing the water a short-circuit path to the springs. This mechanism of recharge and discharge is thought to explain observed increases in discharge at Cane Spring and Whiterock Spring within two to three months after heavy rains (Ingraham et al., 1991). Thordarson (1965) has also documented increased infiltration and discharge at Whiterock Spring after heavy rains. Through oxygen isotopic analyses of rainwater and discharge water from Cane and Whiterock springs, Ingraham et al. (1991) concluded that both summer and winter precipitation are responsible for recharging the perched groundwater. Ingraham et al. (1991) determined the residence time of groundwater at Cane Spring to be approximately 600 years. Lyles et al. (1990) suggested a mean residence time of about 30 years for groundwater at Whiterock Spring. Long-term trends (over several decades) in discharge rates of NTS springs and seeps have not been studied.

\subsubsection{Water Quality}

To understand the regional movement of groundwater, numerous chemical analyses have been conducted at selected springs on or near the NTS by Schoff and Moore (1964), Taylor and Giles (1979), Winograd and Thordarson (1975), and Lyles et al. (1990). Various kinds of water quality data also have been collected at selected springs on the NTS. Moore (1961) recorded water temperature, $\mathrm{pH}$, selected cations and anions, conductivity, alkalinity, and dissolved solids at eight springs. As part of a study of algae, Taylor and Giles (1979) measured various water quality data including $\mathrm{pH}$, water temperature, total alkalinity, total phosphorus, ammonia, and nitrate nitrogen at eight NTS springs. Lyles et al. (1990) recorded water temperature, electrical conductivity, $\mathrm{pH}$, selected cations, and anions at Cane Spring and Whiterock Spring to examine how precipitation events influence temporal water chemistry of springs. Romney and Greger (1992) measured selected cations and 20 mineral elements in spring water from ten sites on the NTS. Stetzenbach (1995) also measured selected anions, cations, and 73 trace metals at three NTS springs.

Moore (1961) measured radioactivity at eight springs on the NTS. Beginning in 1965, DOE began long-term monitoring of radioactivity in four to eight springs on the NTS (Lewis et al., 1965). This monitoring still occurs annually (Davis et al., 1996). Taylor and Giles (1979) measured the uptake of tritium and gamma-emitting radionuclides by algae in eight NTS springs. All of these investigations have reported negligible levels of radioactivity, commensurate with natural background levels or indicative of regional and global fallout as a result of historic aboveground nuclear testing.

\subsubsection{Vegetation}

No systematic inventory of vascular or aquatic plants has been conducted at springs on the NTS. Past botanical surveys have been conducted at only a few of the known springs. They provide lists of species present at or near springs, but the location of hydrophytic 
versus upland plants, relative to the spring source or standing water, has not been clearly documented. The most thorough listing of plants can be found for Cane Spring. Drouet (1960) and Shields and Drouet (1962) recorded 16 aquatic species of algae at Cane Spring. Taylor and Giles (1979) also conducted an algae survey at Cane Spring and at seven other NTS springs. Fifty-two individual species were documented, of which 29 were found at only a single spring. Allred et al. (1963) surveyed four NTS springs (Cane, Tippipah, Topopah, and Whiterock) and listed 33 species of vascular plants located at or near these springs. Beatley (1976) lists 35 species of plants occurring at or near six springs on the NTS.

\subsubsection{Wildlife Use}

The most thorough surveys of selected NTS springs to record the presence of both invertebrates and vertebrates were conducted in the 1960 s by researchers from Brigham Young University (Allred et al., 1963; Jorgensen and Hayward, 1965). Of the four springs surveyed, Cane Spring was studied most extensively. Allred et al. (1963) recorded 5 species of lizards, 5 species of mammals, 18 species of insects, and 70 species of birds at Cane Spring. Hayward et al. (1963) reported 35 species of birds from Cane Spring and only 7,2, and 3 species of birds from Tippipah, Topopah, and Whiterock springs, respectively. Castetter and Hill (1979 and unpublished field notes) reported 45 species of birds observed at Cane Spring from 1975 to 1977.

Giles (1976) examined eight NTS springs to assess the potential costs of improving the availability of water for wildlife at the springs and provided some anecdotal comments on wildlife use at springs. Most wildlife species which were noted as using the sites included mule deer (Odocoileus hemionus), mourning doves (Zenaida macroura), black-tailed jackrabbits (Lepus californicus), coyotes (Canis latrans), and mountain lions (Felix concolor). In 1987, researchers from the University of California at Los Angeles were funded by DOE and began to collect wildlife use data from nine springs on the NTS. A total of 46 vertebrate species, including reptiles, birds, and mammals were observed across all nine springs (Romney and Greger, 1992; Greger and Romney, 1994a,b). · An undescribed species of aquatic snail was observed at Cane Spring during these wildlife use surveys (Greger and Romney, 1994a).

\subsubsection{Historical Use}

Worman (1969) has provided the most extensive historical account of human activities around the NTS springs. Seven springs that occur east and north of the Yucca Mountain area have been identified as important Native American sites (Stoffle et al., 1990a,b; Henton and Pippin, 1988). Also, ethnobotanical studies have been conducted on the NTS which document how Native Americans in the region used numerous wetland plant species (Stoffle et al., 1989). From the available literature, it is known that over 15 NTS springs, seeps, and tanks were used by either miners, homesteaders, or Native Americans. Of these, over 11 springs have been modified in an attempt to increase or contain water flow. The site-specific information on the historical usage of each NTS natural water source,

obtained from these citations, is presented in the following descriptions of each study site. 


\subsection{Description of Study Sites}

This section includes a description of all 25 NTS study sites, including all known springs, seeps, tanks, and natural ponds. The sites are presented in alphabetical order. The data collected at each site are presented so as to clearly describe the presence or absence of field indicators which determine the jurisdictional status of wetlands to facilitate USACE's use of this document as reference material if needed in the future for permitting purposes.

\subsubsection{Ammonia Tanks}

\subsubsection{Site Description and Historical Use}

The Ammonia Tanks are located in a side canyon at the lower end of Stockade Wash, approximately $1 \mathrm{~km}(0.6 \mathrm{mi})$ north of Airport Road (Figure 4-1) and $3 \mathrm{~km}(1.9 \mathrm{mi})$ west of Pahute Mesa Road in Area 18. The site consists of two large natural rock basins (tanks) located below bedrock areas that collect surface runoff and several smaller tanks along a wash channel that drains from these basins. These tanks retain water for a limited time during the year. The Ammonia Tanks site was used by Native Americans from before the 1820 s until about 1950. A fall festival (possibly to harvest wild grains, pinyon nuts, and conduct rabbit drives) was held at the Ammonia Tanks and drew people from Oasis Valley and other areas (Stoffle et al., 1990a). Euroamericans used the tanks around 1900. Man-made rock walls have been added to a large fire-blackened rock shelter near the tanks. The rock walls narrow the entrance of the shelter and form a door opening. Numerous inscriptions occur on the rock wall near the upper tank (Photo 4-1). Some inscriptions of names date to 1904. Old tin cans litter the area around the rock shelter. There appears to be little evidence, however, of human manipulation of the water source.

\subsubsection{Hydrophytic Vegetation}

A routine wetlands survey was conducted at this site on January 7, 1997. Baltic rush (Juncus balticus) was the only wetland species observed at the observation point at the pool of the upper tank and comprised about 8 percent of the cover (Table 4-1). Louisiana sagewort (Artemisia ludoviciana) was the dominant plant species growing at the water source and comprised about 30 percent of the absolute cover. Basin wildrye (Leymus cinereus) and brittlebush (Encelia sp.) also occurred in lesser amounts near the water tank, 5 percent and 2 percent, respectively. The total vegetated area near the two largest tanks was estimated to be about $12 \mathrm{~m}^{2}\left(108 \mathrm{ft}^{2}\right)$. Other plants in the surrounding upland area included big sagebrush (Artemisia tridentata), redstem stork's bill (Erodium cicutarium), mormon tea (Ephedra viridis), cheatgrass (Bromus tectorum), green rabbitbrush (Chrysothamnus viscidifloris), flax (Linum sp.), and antelope bitterbrush (Purshia tridentata). The lower tank had very little vegetation with no hydrophytic species of plants.

\subsubsection{Hydrology}

The site consists of two large tanks and several smaller tanks that vary in size. Two of the largest tanks were each approximately $3 \mathrm{~m}$ by $5 \mathrm{~m}(9.8 \mathrm{ft}$ by $16.4 \mathrm{ft}) \mathrm{ft}$ ) and had estimated depths of $100 \mathrm{~cm}$ (39 in) (Photo 4-2). The tanks fill with water primarily from 


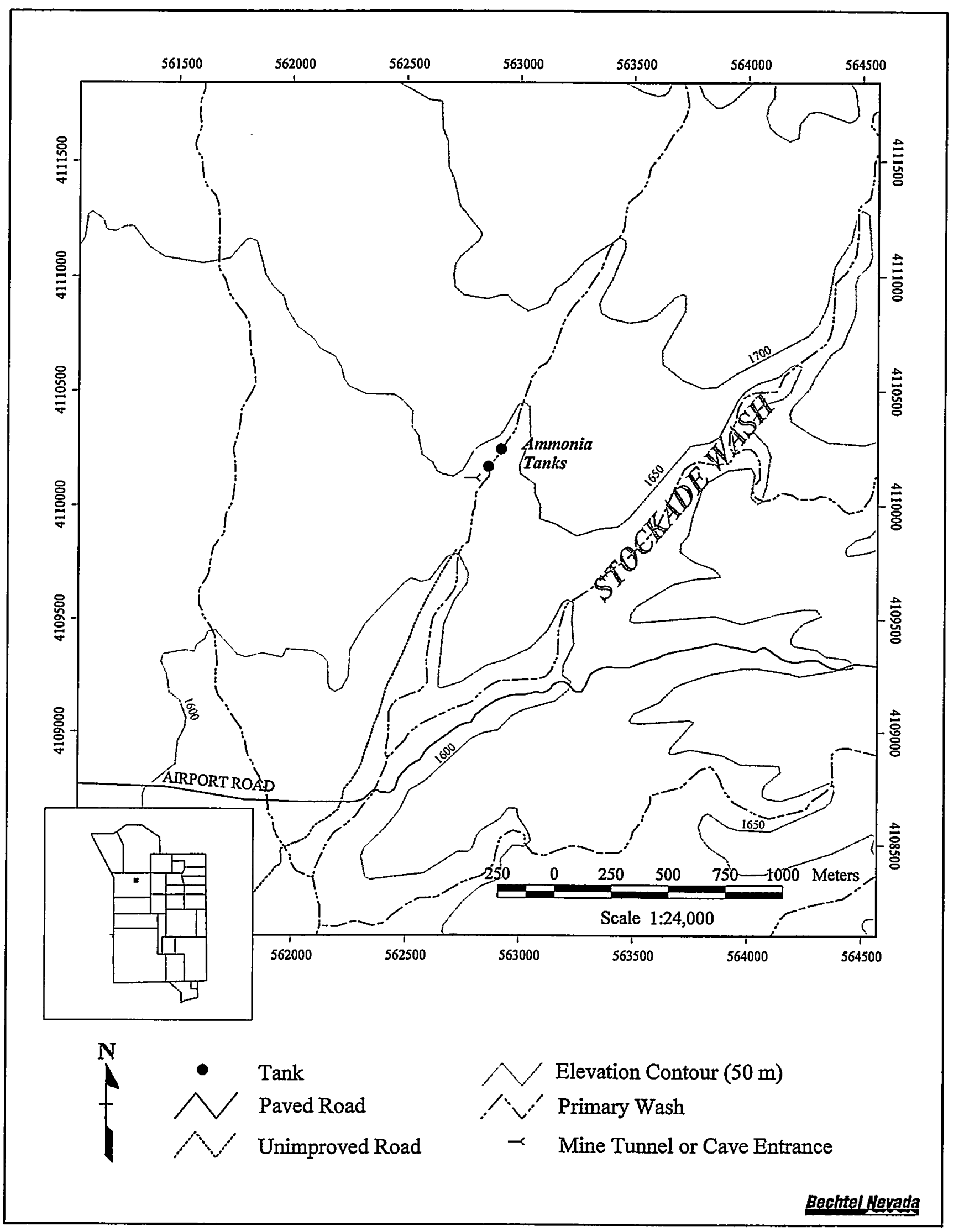

Figure 4-1 Location of Ammonia Tanks 


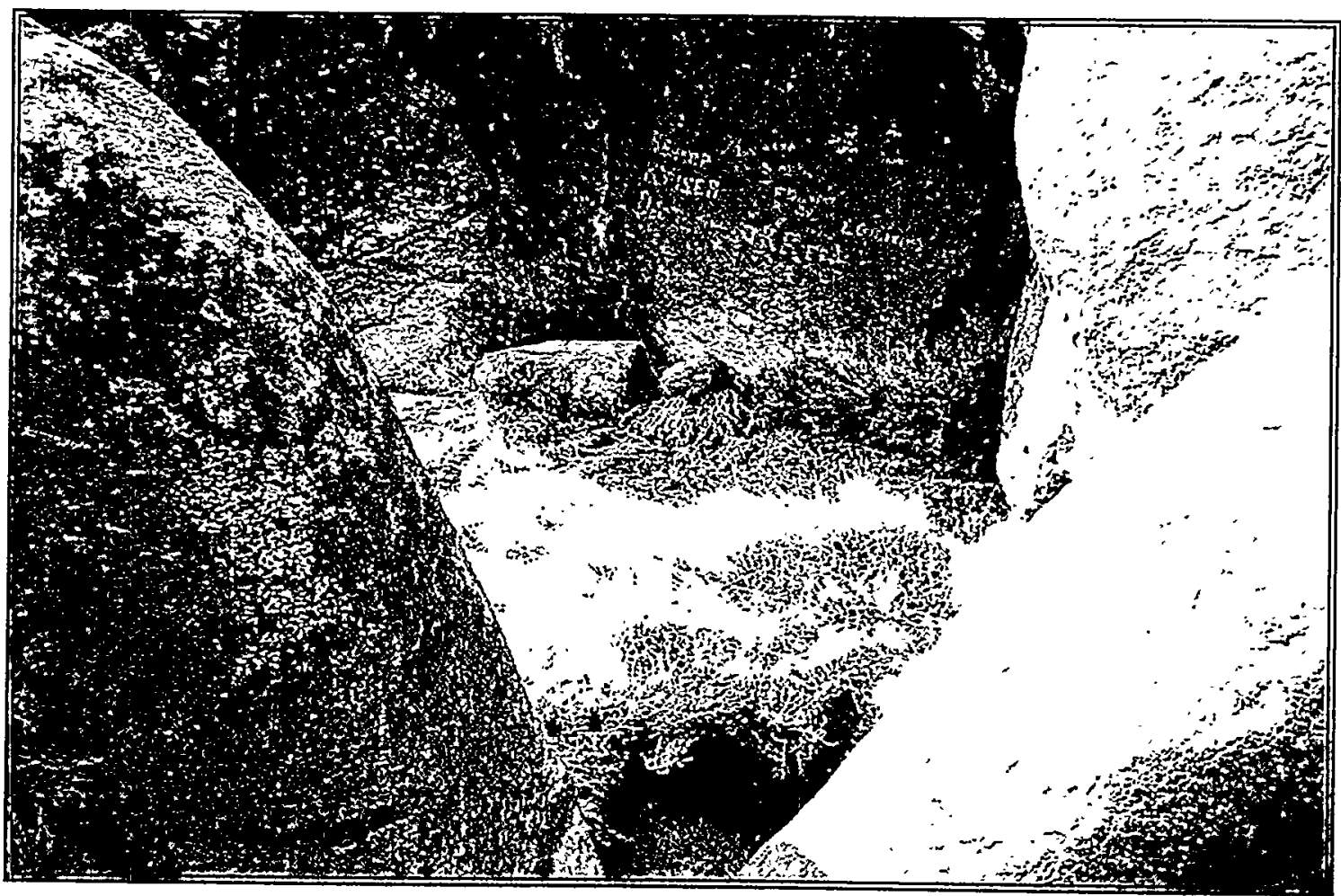
Photo 4-1. Upland vegetation around the upper tank at Ammonia Tanks on January 7, 1997.
(WS346-16.TIF)

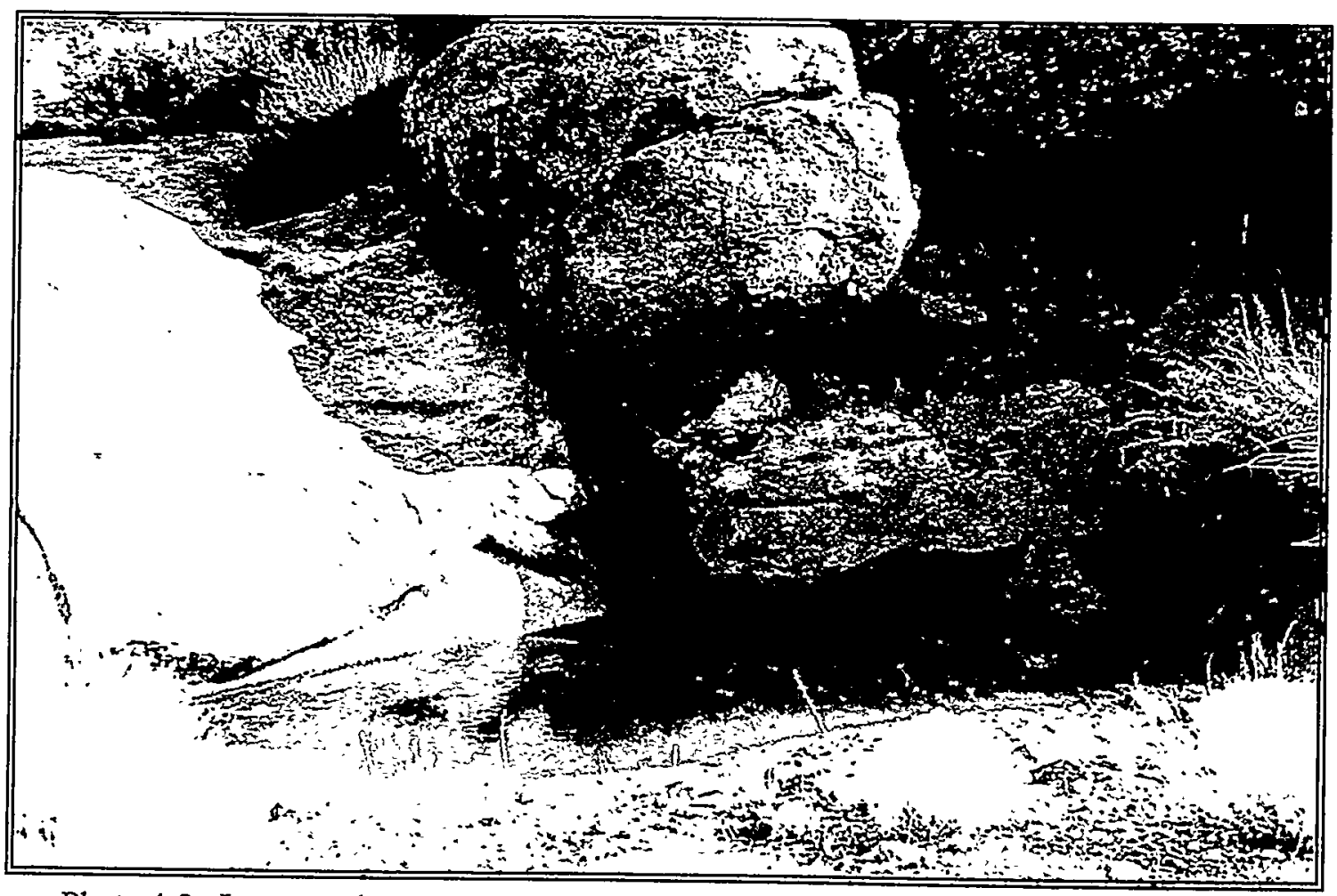

Photo 4-2. Lower tank at Ammonia Tanks looking northeast on January 7, 1997. (WS346-18.TIF) 


\author{
Habitat: Wash Pool

\begin{tabular}{l} 
Species \\
\hline Tree Layer: \\
no species \\
Shrub Layer: \\
no species \\
Herb Layer: \\
Artemisia ludoviciana \\
Encelia sp. \\
Juncus balticus \\
Leymus cinereus
\end{tabular}

\author{
Common Name
}

Indicator Status ${ }^{\mathbf{a}}$

Absolute \% Cover

Percentage of dominant species that are OBL, FACW, or FAC indicator status: Dominant plant species are indicated by bold Absolute \% Cover values.

$\begin{array}{lcc}\text { Louisiana sagewort } & \text { FACU } & 30 \\ \text { unidentified brittlebush } & \text { UNKN } & 2 \\ \text { Baltic rush } & \text { FACW } & 8 \\ \text { basin wildrye } & \text { FACU } & 5\end{array}$

${ }^{\mathrm{a}}$ For Region 8 indicator status codes for plants, see Section 3.2.4.

Hydrophytic vegetation:

No

surface flow. They are located in a narrow, rocky wash with moderate amounts of exposed bedrock upstream. No surface flow from the tanks was observed. No water quality measurements were taken.

\subsubsection{Hydric Soils}

Field indicators of hydric soils were restricted to small accumulations of soil fines located downslope of the tank above bedrock where soil appeared to be saturated for at least seven days during the growing season, indicating the presence of hydric soils.

\subsubsection{Determination of Jurisdictional Status}

Because of a lack of hydrophytic vegetation at Ammonia Tanks, this site would probably not be considered a jurisdictional wetland.

\subsubsection{Wildlife Use}

Little is known of wildlife use of the area; however, deer and coyote scat and tracks were observed near the water source, suggesting use by these species. 


\subsubsection{Cane Spring}

\subsubsection{Site Description and Historical Use}

Cane Spring is located at the northeast end of Skull Mountain near the junction of Cane Spring Road and Area 27 Road, south of Cane Spring Wash (Figure 4-2). The Cane Spring site (Photo 4-3) has a moderate slope (30 percent) with a north-facing aspect. Native Americans occupied the site and cultivated corn and squash (Stoffle et al., 1990a). Present historical structures on site include an old rock and wood house with a corral built to hold relay horses for a freight line that ran from Utah to southern Nevada prior to 1900 (Worman, 1969). A tunnel was excavated into the spring, apparently by ranchers or miners, to improve the flow of water, forming a horizontal shaft (an adit) and cave pool (Photo 4-4). The adit is about $3 \mathrm{~m}(9.8 \mathrm{ft})$ wide, more than $1 \mathrm{~m}(3.3 \mathrm{ft})$ in diameter, and of undetermined length into the hillside. Water from this site was hauled to the mining camp (tent town) of Wáhmonie in 1928. A local gravesite near the spring dates to 1922. Livestock and some feral horses occupied the area until at least 1976 (Giles, 1976) and probably grazed heavily on wetland vegetation.

Water from the cave pool flows through a drainage channel about $30 \mathrm{~m}(98 \mathrm{ft})$ north to a man-made reservoir (Figure 4-2). This reservoir is known to fill with water during wet years (Photo 4-5), but was dry during site visits in 1996 (Photo 4-6). The reservoir was apparently created by early ranchers who constructed an earthen berm across the drainage channel. The berm also functions as a road. Spring water also flows intermittently from a seep adjacent to a large Goodding's willow (Salix gooddingii) tree inside a fenced area to the east of the cave pool (Figure 4-2). This area was fenced by DOE in the early 1970 s to protect largeflower suncup (Cane Spring evening primrose) (Camissonia megalantha) from grazing by feral horses (this plant was believed to be locally rare and threatened on the NTS [Rhoads and Williams, 1977]). Water flows from this seep through another drainage channel into the reservoir (Figure 4-2). A wooden flow gauge box has been installed about $20 \mathrm{~m}(66 \mathrm{ft}$ ) downslope from the cave pool (Figure 4-2) and is fed water through a PVC (polyvinyl chloride) pipe. An existing bladed road into the Cane Spring site was barricaded by DOE some time in the 1970s to protect this historical site from future human disturbance.

\subsubsection{Hydrophytic Vegetation}

A mosaic of small wetland habitats comprise the Cane Spring site as shown in Figure 4-2. Wetland plant species observed at the site include Baltic rush, rabbitsfoot grass (Polypogon monspeliensis), Goodding's willow, and saltcedar (Tamarix ramosissma). On a hill slope above the pool (Photo 4-3), a small $70-\mathrm{m}^{2}$ (753- $\mathrm{ft}^{2}$ ) delta, with an accumulation of over $2 \mathrm{~m}(6.6 \mathrm{ft})$ of fines, supports a mixture of Baltic rush and basin wildrye. A small stand $\left(25 \mathrm{~m}^{2}\right.$ [269 $\left.\left.\mathrm{ft}^{2}\right]\right)$ of southern cattail (Typha domingensis) stalks occurs below the flow gauge box. Four to five large (5 to $15 \mathrm{~m}$ [16.4 to $49.2 \mathrm{ft}$ ] tall) Goodding's willow trees on the site offer significant cover to wildlife. Southern cattails were recorded growing in the seep under these willows in September of 1996. Common upland plant species growing in the area include fourwing saltbush (Atriplex canescens), foxtail brome (Bromus rubens), cheatgrass, rubber rabbitbrush (Ericameria [Chrysothamnus] nauseosa), and blackbrush (Coleogyne ramosissima. Largeflower suncup (Cane Spring evening primrose) was first described from Cane Spring (Beatley, 1976). Two additional wetland 


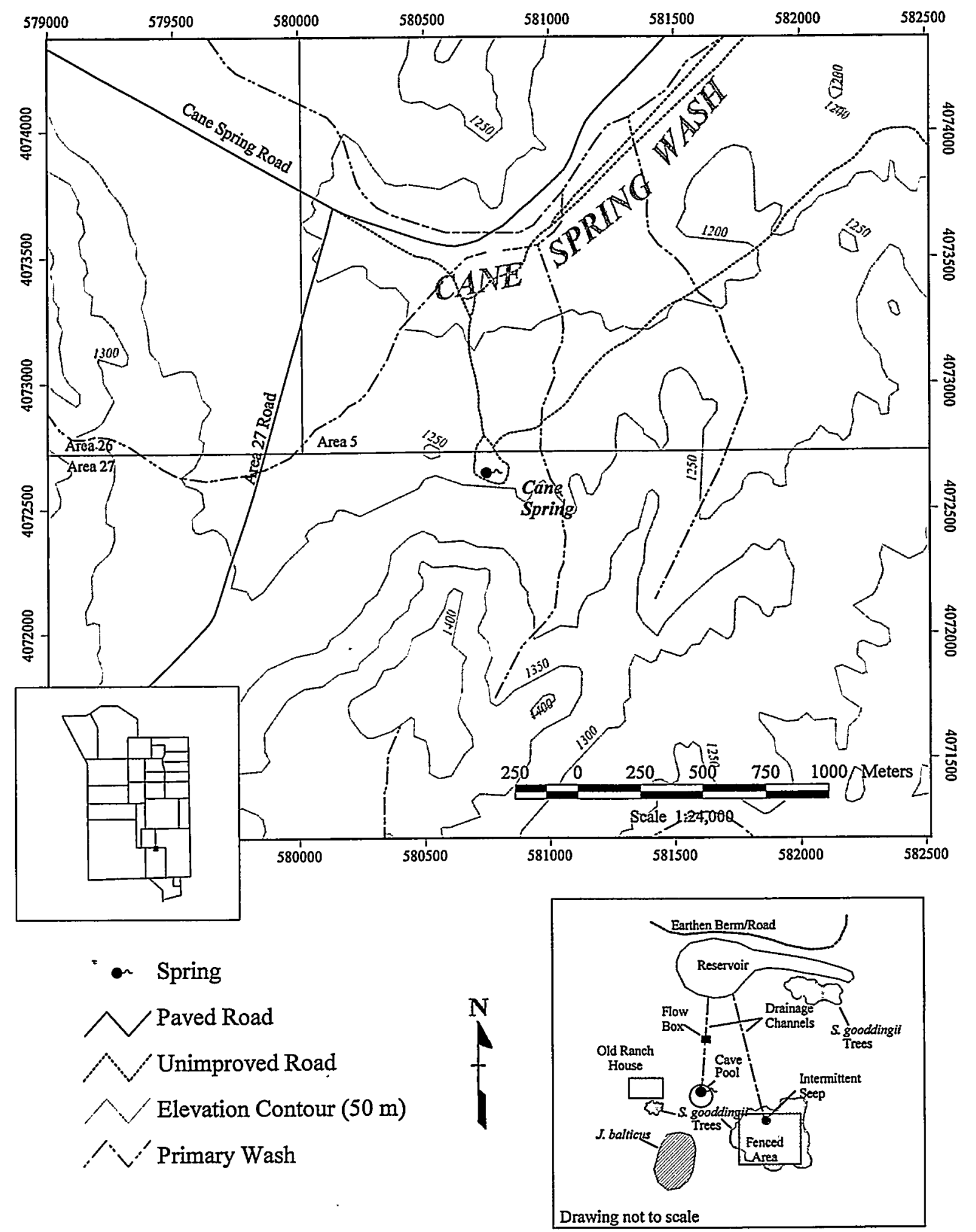

Bechtel Nevada

Figure 4-2 Location and sketch of Cane Spring 


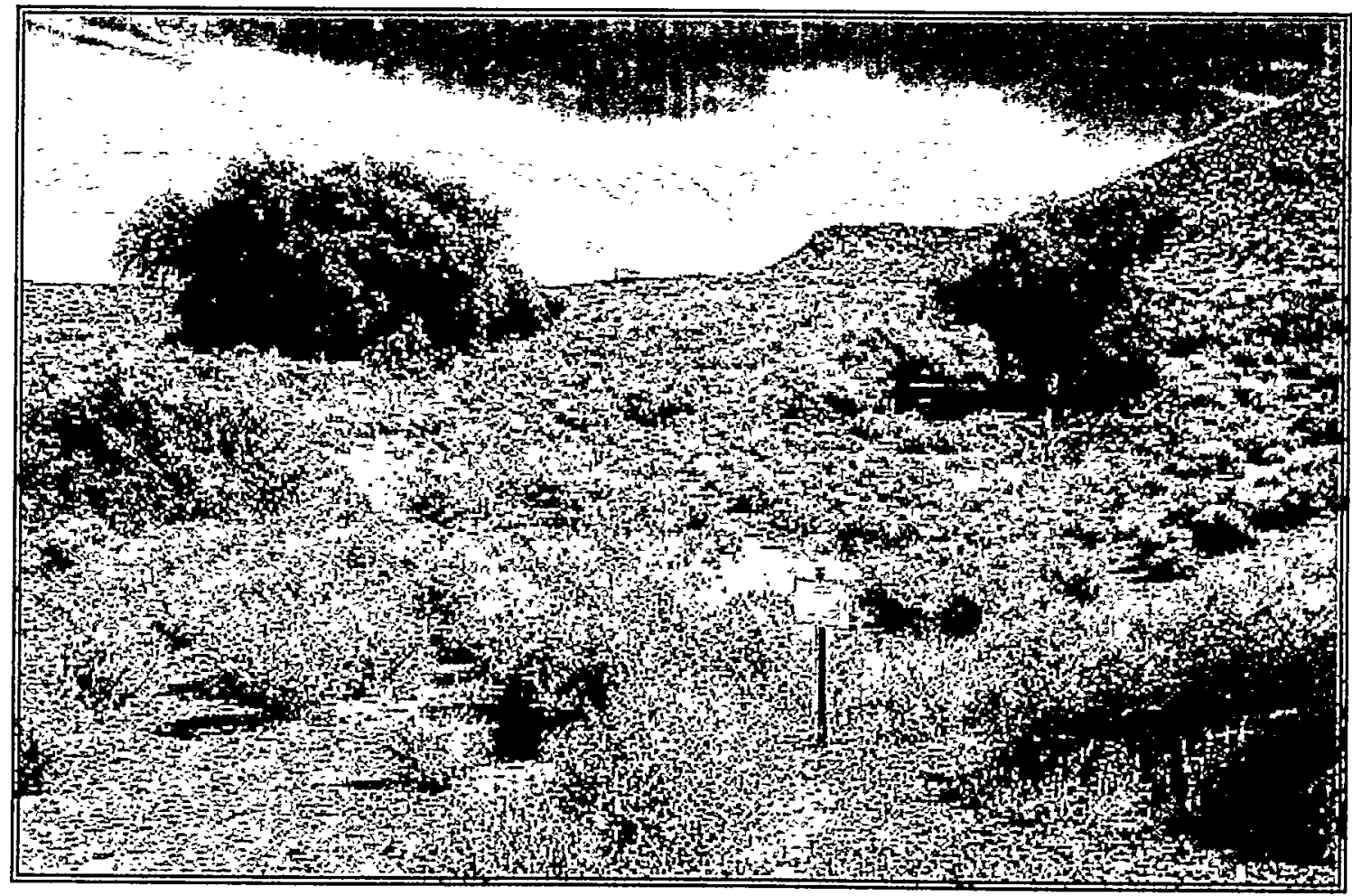

Photo 4-3. Cane Spring area, looking southeast on June 19, 1996. (WS339-08.TIF)

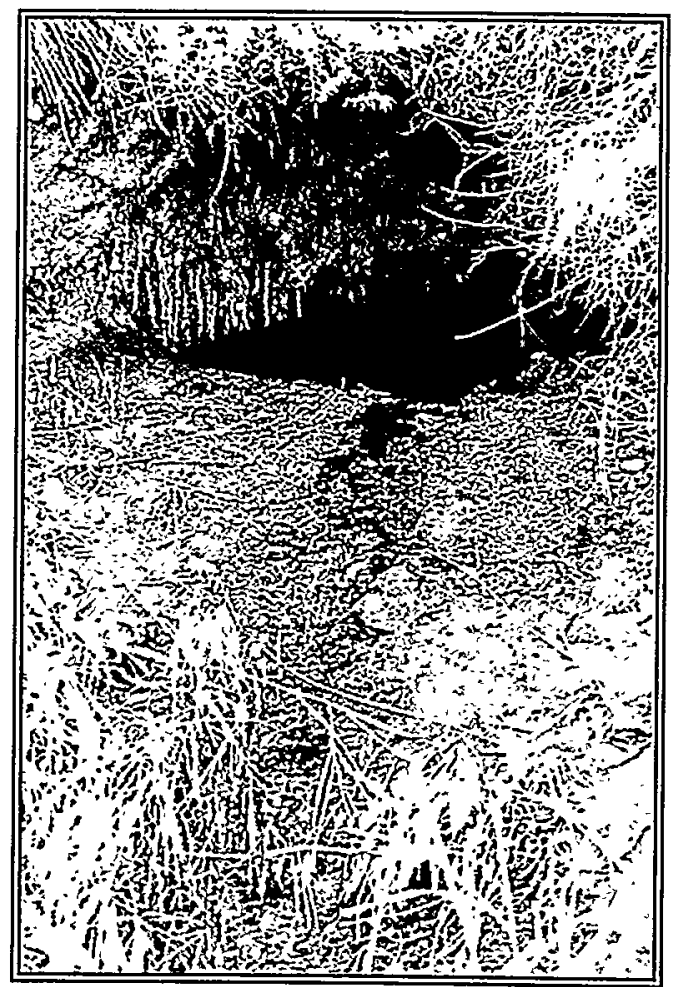

Photo 4-4. Cave pool and outflow at

Cane Spring on June 19, 1996. (WS34419.TIF) 


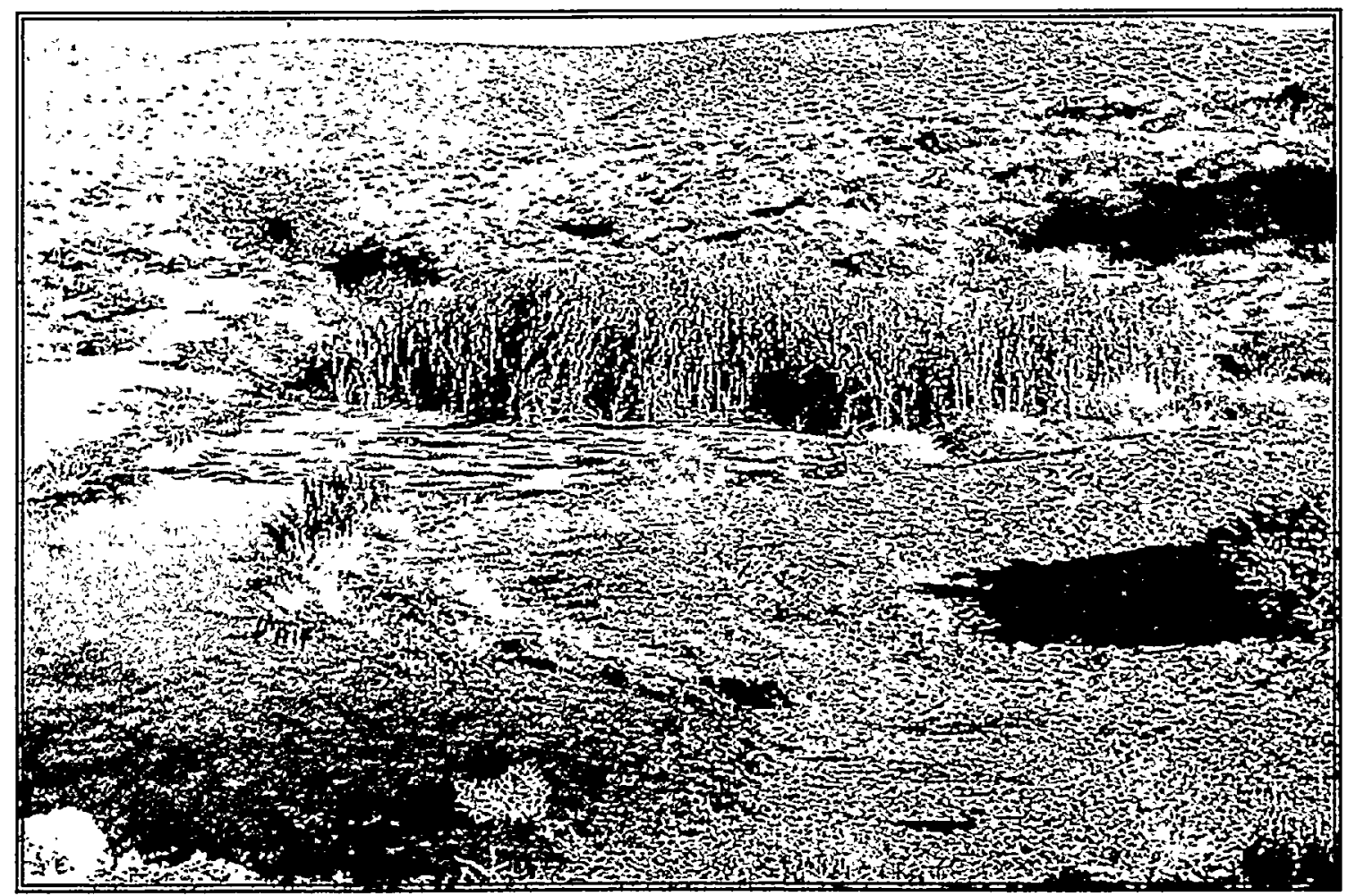

Photo 4-5. Reservoir at Cane Spring, looking east in 1963 (Allred et al., 1963). (WS500-01.TIF)

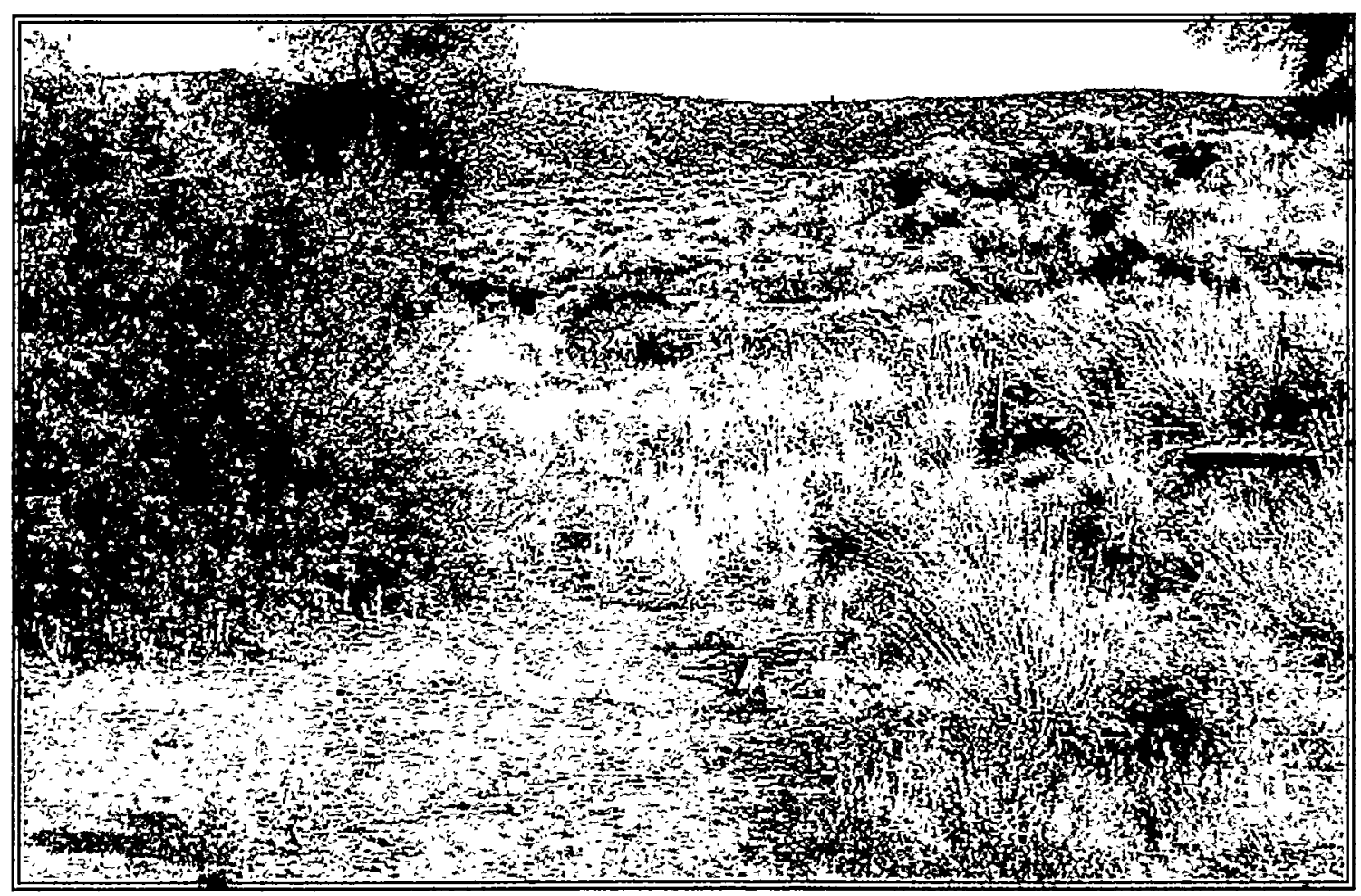

Photo 4-6. Dry reservoir at Cane Spring, looking east on November 14, 1996. (wS501-01.TIF) 
species were reported to occur at Cane Spring in 1988 that were not observed during the 1996 field survey: common reed (Phragmites australis) and western honey mesquite (Prosopis glandulosa) (Stoffle et al., 1989). Beatley (1976) stated that three small western honey mesquite trees were apparently planted at Cane Spring and that they were not known to flower.

A wetland plant survey was conducted in the drainage channel $5 \mathrm{~m}(16.4 \mathrm{ft})$ directly down slope from the cave pool on June 19, 1996. In this area, approximately 33 percent of the dominant plants observed were hydrophytic, a value too low for the area downslope from the cave pool to be considered a jurisdictional wetland (Table 4-2). The seep site, however, had a dominance of hydrophytic plants ( $>51$ percent) when surveyed in September 1996 (Table 4-3). These hydrophytic plants included Baltic rush, southern cattail, and Goodding's willow which were growing in saturated soils. This area of about $230 \mathrm{~m}^{2}\left(2,475 \mathrm{ft}^{2}\right)$ (Table 5-1, Section 5.0) has field indicators positive for hydrophytic vegetation.

Table 4-2 Cane Spring wetland vegetation as surveyed on June 19, 1996

\section{Habitat: Drainage Channel Below Cave Pool}

\begin{tabular}{|c|c|c|c|}
\hline Species & Common Name & Indicator Status ${ }^{2}$ & Absolute $\%$ Cover \\
\hline $\begin{array}{l}\text { Tree Layer: } \\
\text { no species }\end{array}$ & & & \\
\hline $\begin{array}{l}\text { Shrub Layer: } \\
\quad \text { Atriplex canescens }\end{array}$ & fourwing saltbush & UPL & 15 \\
\hline $\begin{array}{l}\text { Herb Layer: } \\
\text { Leymus cinereus } \\
\text { Rumex salicifolius }\end{array}$ & $\begin{array}{l}\text { basin wildrye } \\
\text { willow dock }\end{array}$ & $\begin{array}{l}\text { FACU } \\
\text { FACW* }\end{array}$ & $\begin{array}{l}40 \\
15\end{array}$ \\
\hline
\end{tabular}

Percentage of dominant species that are OBL, FACW, or FAC indicator status: $33 \%$. Dominant plant species are indicated by bold Absolute \% Cover values.

${ }^{\mathrm{a}}$ For Region 8 indicator status codes for plants, see Section 3.2.4.

Hydrophytic vegetation:

No

Table 4-3 Cane Spring wetland vegetation as surveyed on September 9, 1996

\section{Habitat: Seep Under Willow Trees}

\begin{tabular}{|c|c|c|c|}
\hline Species & Common Name & Indicator Status ${ }^{\mathrm{a}}$ & Absolute \% Cover \\
\hline $\begin{array}{l}\text { Tree Layer: } \\
\quad \text { Salix gooddingii }\end{array}$ & Goodding's willow & FACW & 90 \\
\hline $\begin{array}{c}\text { Shrub Layer: } \\
\text { no species }\end{array}$ & & & \\
\hline
\end{tabular}




\section{Habitat: Seep Under Willow Trees}

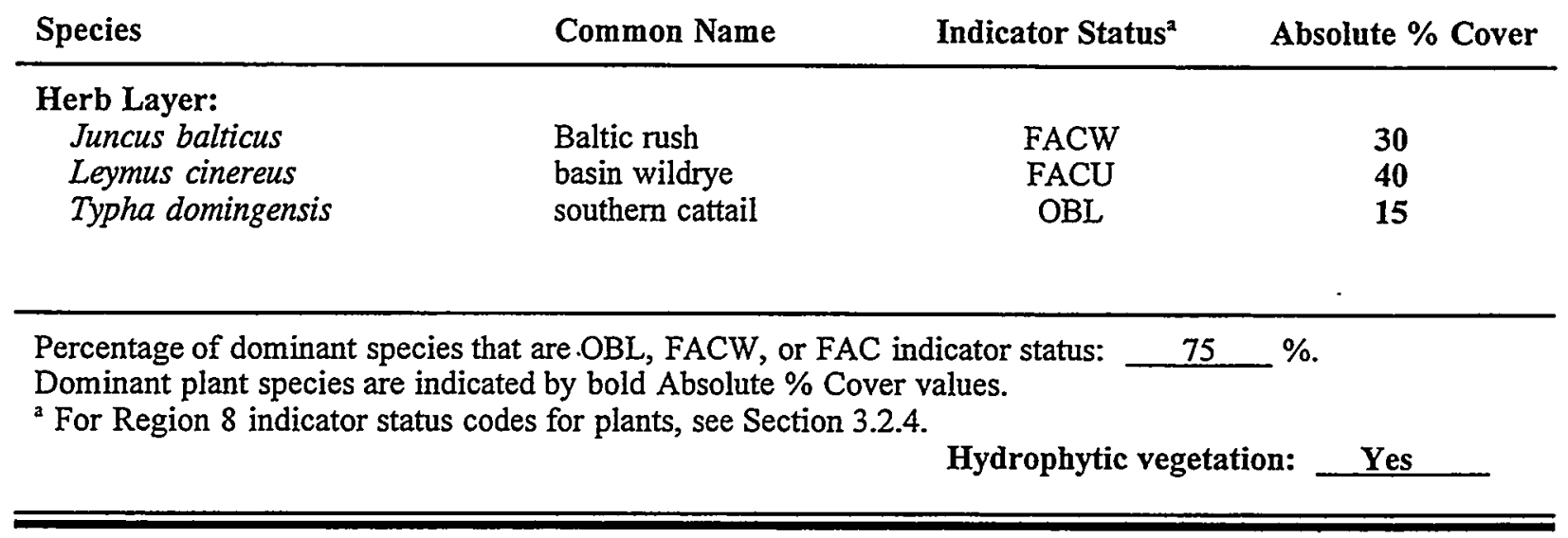

\subsubsection{Wetland Hydrology and Water Quality}

Areas observed to have field indicators of wetland hydrology included the cave pool and the seep area inside the fence to the east of the cave pool. The amount of surface water increased visibly from June to November 1996 due to precipitation. On June 19, 1996, surface water was observed only in the cave pool and in the flow gauge box. On September 9, 1996, surface water was seeping through the earthen dam forming saturated soils below the cave pool and was also flowing from the seep within the fenced area under the Goodding's willow tree, forming a 4- $\mathrm{m}^{2}\left(43-\mathrm{ft}^{2}\right)$ inundated area. On November 14 , 1996, water was flowing over the cave dam and had inundated a small area 1 to $2 \mathrm{~m}^{2}$ (11 to $21 \mathrm{ft}^{2}$ ) and 10 to $15 \mathrm{~cm}$ (4 to $6 \mathrm{in}$ ) deep just below the cave dam in the main drainage channel.

The flow rates of surface water at Cane Spring also increased from June to November. During June, no flow was observed into the flow gauge box from the cave pool via an existing PVC pipe. In September, the flow rate into the box was $0.015 \mathrm{l} / \mathrm{min}(0.004$ $\mathrm{gal} / \mathrm{min}$ ). In November, water was flowing over the cave dam at a measured rate of $3 \mathrm{l} / \mathrm{min}(0.8 \mathrm{gal} / \mathrm{min})$. The flow rate of water into the flow gauge box was not noticeably greater, however, than in September, but it was not measured.

The depth of water in the cave pool also increased from June to November. The cave pool is about $2 \mathrm{~m}(6.6 \mathrm{ft})$ inside the cave opening. On June 6, 1996, water depth of the pool was about $60 \mathrm{~cm}(24 \mathrm{in})$. In September, the water level rose about $10 \mathrm{~cm}(4 \mathrm{in})$, but had not overflowed the cave dam. In November, the water depth measured was greater

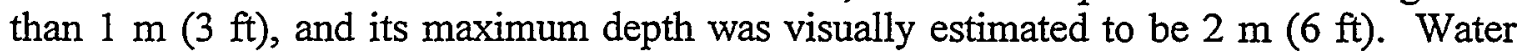
quality data were taken at the cave pool and the flow box in June, September, and November 1996. These water quality data are presented in Table 5-2 (Section 5.0).

\subsubsection{Hydric Soils}

Several field indicators of hydric soils were found at the cave pool and the seep area inside the fence and included dark (low-chroma) organic profiles, mottling, and evidence 
of saturated soils. Soil, eroding by sheet erosion from slopes adjacent to the site, appears to have collected or been trapped by the dense vegetation of sedges and grasses growing at the seep. This has resulted in the accumulation of soil fines to a moderate depth of 2 to 3 $\mathrm{m}$ (6.6 to $9.8 \mathrm{ft}$ ) (based on comparisons with adjacent topographic contours) which has apparently accumulated over hundreds or perhaps thousands of years. The strongest evidence of hydric soils is the occurrence of soils that appear to have been saturated or inundated for greater than seven days during the plant growing season (see Section 3.2.6).

\subsubsection{Determination of Jurisdictional Status}

Portions of the Cane Spring site may qualify as jurisdictional wetlands because they have field indicators for all three required parameters: hydrophytic vegetation, wetland hydrology, and hydric soils. The seep area within the fenced area which supports Goodding's willow, Baltic rush, and southern cattail qualifies as a jurisdictional wetland. While the area directly downslope from the cave pool did not have a dominance of hydrophytic vegetation during the surveys, it is likely that during wetter periods of time, this area would also have more hydrophytic species and would probably be considered a jurisdictional wetland. The size of these two areas fluctuates with seepage and will vary over time. The cave pool was unvegetated and therefore did not meet the criteria of a jurisdictional wetland. However, the pool may be considered by the USACE to be waters of the United States protected under the CWA.

\subsubsection{Wildlife Use}

The area is used heavily for drinking and resting sites by numerous migrating birds including passerines (perching song birds), mourning doves, and resident species such as chukar (Alectoris chukar) and Gambel's quail (Callipepla gambelii) (Table 5-4, Section 5.0). The large Goodding's willow trees provide nesting sites for common ravens (Corvus corax) and long-eared owls (Asio otus). Bobcats (Lynx rufus), coyotes, mountain lions, and mule deer are some common mammals that use the area. Mule deer tracks at the cave pool entrance indicate the opening is large enough for this species to access the pool.

An undescribed species of hydrobiid snail (Pyrgulopsis sp.) occurs at Cane Spring. From June through November 1996, the snail was found on several algal mats in the cave pool nearest the tunnel entrance. Previous field records show that the snail occurred in the east channel (Paul Greger, unpublished data, 1988) and was collected from the wooden flow gauge box in 1992. The east channel was dry and had no snails in June 1996. Other invertebrates including both ostracods and copepods occur at this spring.

\subsubsection{Captain Jack Spring}

\subsubsection{Site Description and Historical Use}

Captain Jack Spring (Figure 4-3) occurs in a rocky, remote area at the northeastern end of the Eleana Range on steep slopes with a southeast-facing aspect. Native American cultural sites, including two rock shelters and various other artifacts, are located at short distances from the spring (Worman, 1969). The area was occupied and named after an early Native American explorer who carried mail from Utah to the Groom Mine (Worman, 1969). Livestock was kept in the area as evidenced by the presence of an old corral. Remnants of old livestock watering tanks and old pipes occur about $30 \mathrm{~m}$ (98 ft) 


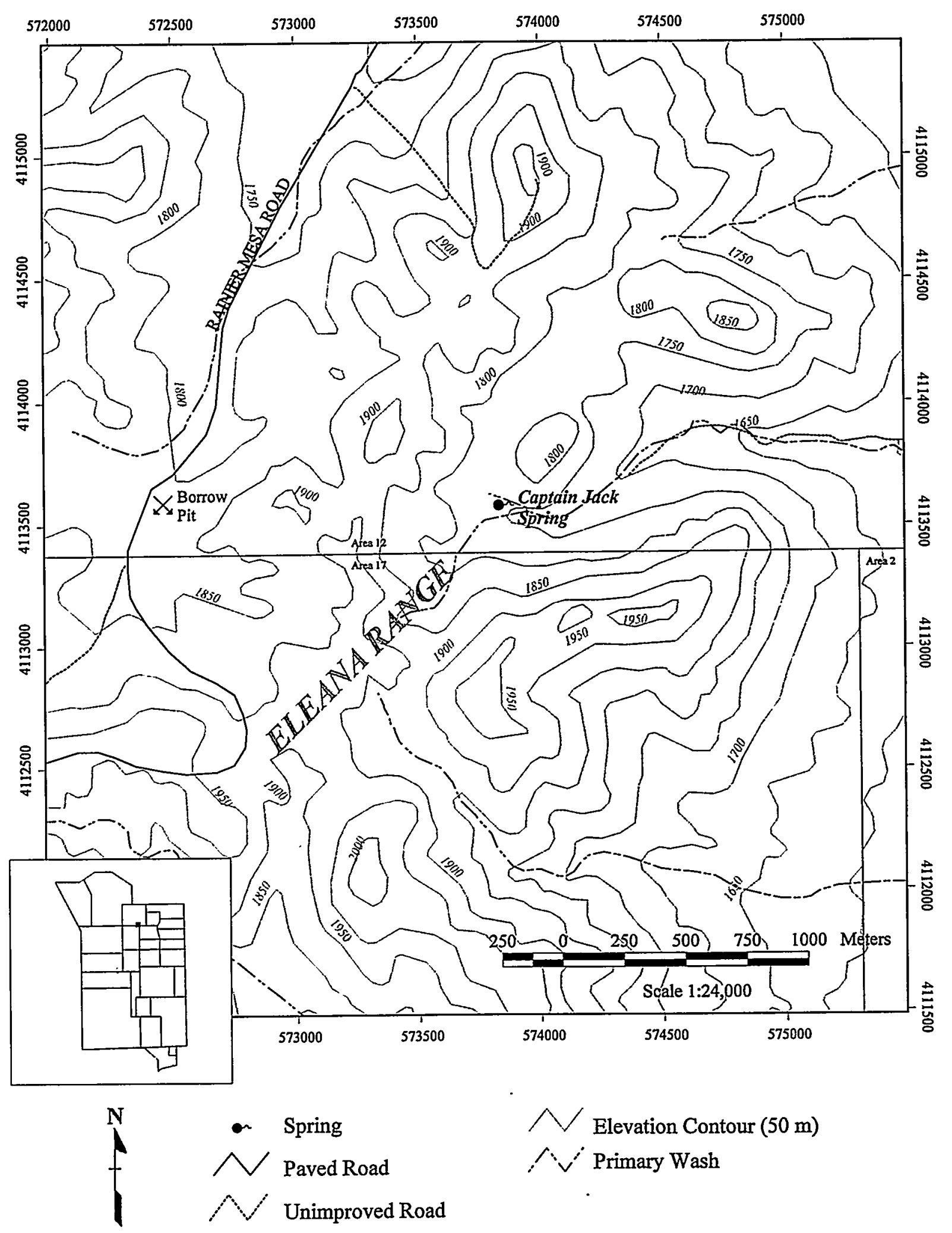

Bechtel Hevada

Figure 4-3 Location of Captain Jack Spring 
below the spring pool. The old pipes (not functional) apparently fed water to the tanks for livestock. After flood damage, new pipes were installed and a new watering tank was bolted to the bedrock (Smith et al., 1979).

Water flows from the base of a narrow rocky box canyon which is about $5 \mathrm{~m}(16.4 \mathrm{ft})$ wide by $15 \mathrm{~m}(49.2 \mathrm{ft})$ long. The water forms a pool $61 \times 76 \mathrm{~cm}(24 \times 30 \mathrm{in})$ which is about $20 \mathrm{~cm}$ ( 8 in) deep (Photo 4-7). This pool drains downslope through a channel. This small stream of water was about $30 \mathrm{~m}$ (131 ft) long and $20 \mathrm{~cm}(8 \mathrm{in})$ wide. The drainage channel is at times thickly vegetated with aquatic plants (Photo 4-8). A small herd of about 20 feral horses occupies the area (Photo 4-9) (Greger and Romney, 1994b). Use of the spring by horses varies with the season, and heavy grazing and trampling by horses results in seasonal reductions in the absolute cover of wetland vegetation at the site (Photo 4-10).

\subsubsection{Hydrophytic Vegetation}

Captain Jack Spring occurs in typical pinyon-juniper habitat where localized patches of Gambel's oak (Quercus gambelii) are common around the base of rocky ledges. Upland species include Louisiana sagewort, big sagebrush, foxtail brome, cheatgrass, mormon tea, eastern Mojave buckwheat (Eriogonum fasciculatum), Utah juniper (Juniperus osteosperma), basin wildrye, singleleaf pinyon (Pinus monophyla), and bluegrasses (Poa spp.). Wetland plant species in the area around the spring and within the drainage channel include seep monkeyflower (Mimulus guttatus), biennial cinquefoil (Potentilla biennis), willow dock (Rumex salicifolius), water speedwell (Veronica anagallis-aquatica), and bridge penstemon (Penstemon rostriflorus).

On June 19, 1996, the spring drainage channel was nearly denuded of aquatic vegetation for most of its length coincident with heavy horse usage. On September 19, 1996, vegetation had regrown and there was extensive growth of aquatic vegetation throughout the total length of the drainage channel and the pool. This vegetated area was approximately $30 \mathrm{~m}^{2}$ (323 $\mathrm{ft}^{2}$ ) (Photo 4-8). A wetland vegetation survey was conducted in the drainage channel of Captain Jack Spring about $25 \mathrm{~m}$ (82 ft) downslope of the spring pool. Results showed that 100 percent of the dominant species observed were hydrophytic plants indicating that field indicators for hydrophytic vegetation are present at Captain Jack Spring (Table 4-4).

\subsubsection{Wetland Hydrology and Water Quality}

Areas observed to have field indicators of wetland hydrology included the spring pool and the drainage channel below the pool. Water flow rate was approximately $0.9 \mathrm{l} / \mathrm{min}(0.2$ $\mathrm{gal} / \mathrm{min}$ ) on September 10, 1996 (Table 5-1, Section 5.0). The total inundated area at Captain Jack Spring was about $7 \mathrm{~m}^{2}\left(75 \mathrm{ft}^{2}\right)$ during September 1996. The spring pool is less than $0.5 \mathrm{~m}^{2}\left(4.9 \mathrm{ft}^{2}\right)$ in surface area and contains an estimated volume of about $70 \mathrm{~L}$ (18.5 gal). Surface water and saturated soils were present at Captain Jack Spring on both visits during June and September 1996. Water quality data were taken during both visits and are presented in Table 5-2 (Section 5.0). 


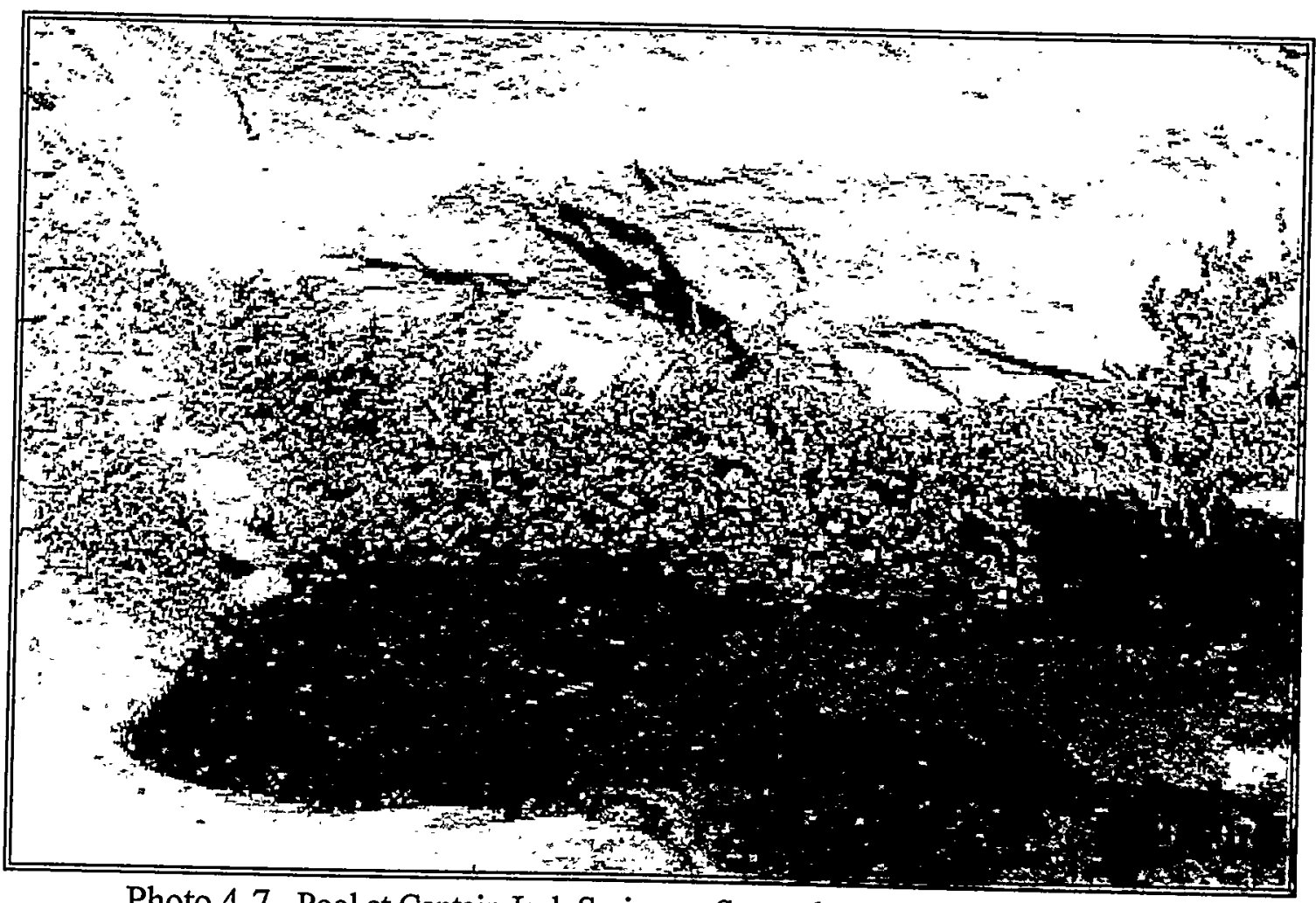

Photo 4-7. Pool at Captain Jack Spring on September 10, 1996. (WS340-19.TIF)

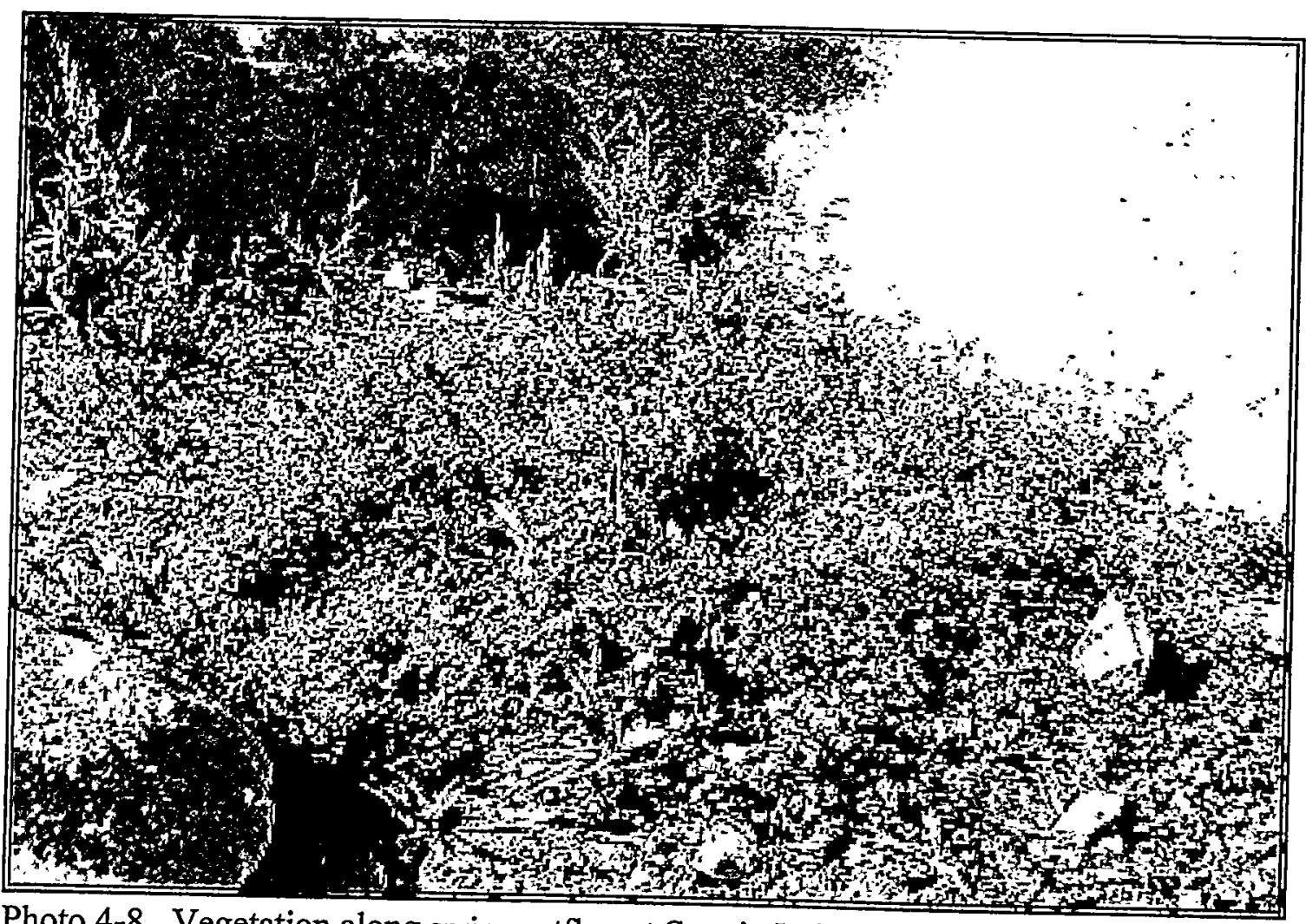

Photo 4-8. Vegetation along spring outflow at Captain Jack Spring on September 10, 1996.
(WS340-18.TIF) 


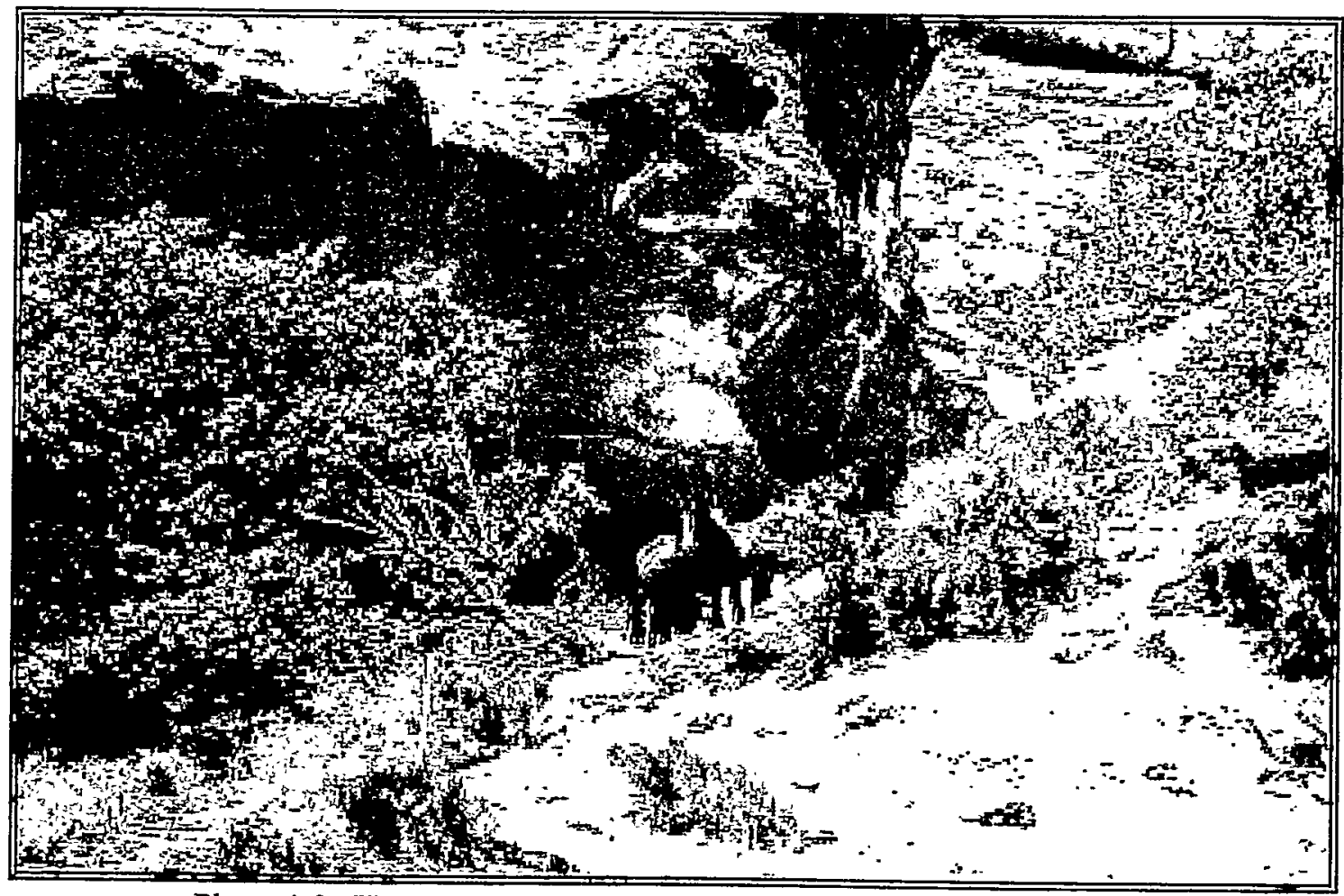

Photo 4-9. Horses at Captain Jack Spring on June 1989. (WS112-16.TIF)

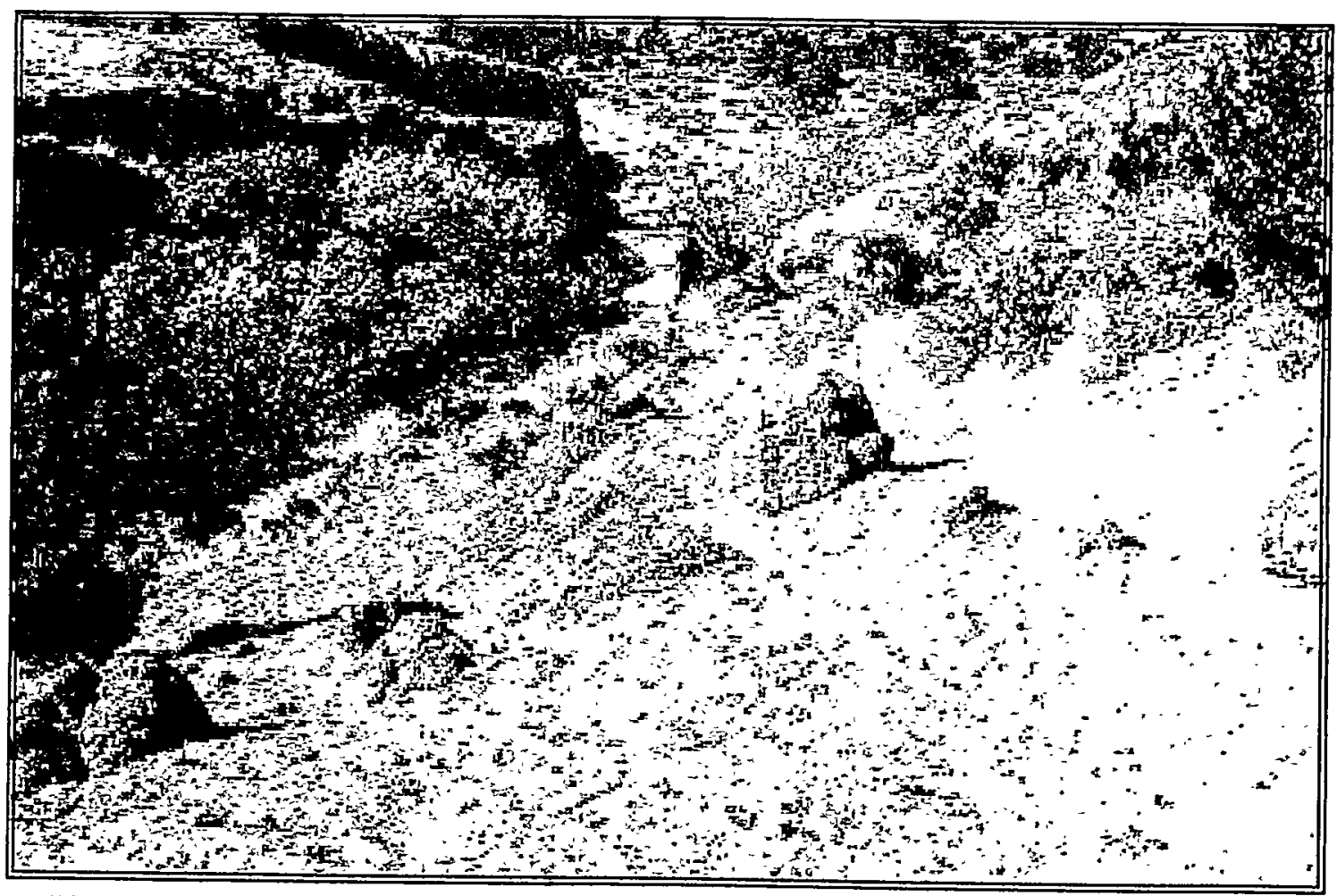

Photo 4-10. Horse damage at Captain Jack Spring on November 21, 1988. (Ws104-04.TIF) 


\begin{tabular}{|c|c|c|c|}
\hline Species & Common Name & Indicator Status ${ }^{2}$ & Absolute $\%$ Cover \\
\hline \multicolumn{4}{|l|}{$\begin{array}{l}\text { Tree Layer: } \\
\text { no species }\end{array}$} \\
\hline $\begin{array}{l}\text { Shrub Layer: } \\
\text { no species }\end{array}$ & & & \\
\hline \multicolumn{4}{|l|}{ Herb Layer: } \\
\hline Mimulus guttatus & seep monkeyflower & OBL & 10 \\
\hline Potentilla biennis & biennial cinquefoil & FAC & 5 \\
\hline Rumex salicifolius & willow dock & FACW* & $\mathbf{5 0}$ \\
\hline Veronica anagallis-aquatica & water speedwell & OBL & 10 \\
\hline
\end{tabular}

Percentage of dominant species that are OBL, FACW, or FAC indicator status: $100 \%$.

Dominant plant species are indicated by bold Absolute \% Cover values.

${ }^{a}$ For Region 8 indicator status codes for plants, see Section 3.2.4.

Hydrophytic vegetation:

Yes

\subsubsection{Hydric Soils}

Field indicators of hydric soils were limited at this site. Soils were poorly developed, shallow, and sandy in this region with low amounts of organic matter. Areas identified as having hydric soils were confined to the spring pool and the narrow drainage channel where the soils appeared to be saturated for seven or more days during the growing season, indicating the presence of hydric soils.

\subsubsection{Determination of Jurisdictional Status}

Two areas at Captain Jack Spring (the spring pool and the narrow drainage channel below the pool) would probably qualify as jurisdictional wetlands because they had field indicators for all three required parameters: hydrophytic vegetation, wetland hydrology, and hydric soils.

\subsubsection{Wildlife Use}

This spring is commonly used by coyotes, feral horses, mountain lions, mule deer, and large numbers of upland game birds such as chukar, Gambel's quail, and mourning doves. Sixteen or more species of passerine birds have been recorded using the spring habitat (Table 5-4, Section 5.0). Raptors are also common in this area, including the Cooper's hawk (Accipiter cooperii) and the sharp-shinned hawk (Accipiter striatus). Tiny freshwater crustaceans such as ostracods and copepods are common in the spring pool. 


\subsubsection{Cottonwood Spring}

\subsubsection{Site Description and Historical Use}

Cottonwood Spring is located northwest of Calico Hills about $1 \mathrm{~km}(0.6 \mathrm{mi})$ west of Fortymile Canyon (Figure 4-4). This spring occurs in an east-facing wash at the top of a steep (40 percent) slope. It flows from fractures in rock ledges at approximately a 1,292$\mathrm{m}(4,240-\mathrm{ft})$ elevation and is visible from a distance because three cottonwood trees (Populus fremontii) occur at the spring (Photo 4-11). The spring is marked on the Topopah Spring NW USGS 7.5-Minute Series quadrangle map (1961), but is not named. This spring is the only site on the NTS where a cottonwood tree exists; therefore, the spring was named "Cottonwood Spring." The spring was used by Native Americans, as evidenced by a temporary camp site which is located just above the spring on the ridge face at $1,310 \mathrm{~m}(4,300 \mathrm{ft})$. This site has three rock shelters and one rock alignment (Henton and Pippin, 1988). Prospecting and mining occurred in Fortymile Canyon near this spring. A surviving Forty-Niner emigrant claimed to have found some ore in Fortymile Canyon near a spring with a cottonwood tree close to the junction of several Native American trails (Stoffle et al., 1990a). A prospector set out to find the spring in 1880 and was attacked by Native Americans and driven away (Stoffle et al., 1990a).

There appears to be little evidence of human disturbance at this spring. A few pieces of iron pipe were located in the wash about $100 \mathrm{~m}(328 \mathrm{ft}$ ) below the spring, suggesting that water was piped down the wash. A few pieces of metal rebar were also found near the cottonwood trees.

\subsubsection{Hydrophytic Vegetation}

A wetland vegetation survey was conducted on December 12, 1996. Within the sampling area (observation point), 66 percent of the dominant plants were hydrophytic species indicating that hydrophytic vegetation was present at Cottonwood Spring (Table 4-5). Seep monkeyflower was the dominant species growing throughout the entire habitat; however, most of these individuals were very young plants of $1 \mathrm{~cm}(0.5 \mathrm{in})$ in height or less (Photo 4-12). Old flowering stalks of last year's plants remained. Mosses and western goldfern (Pentagrama triangularis) were also widely distributed throughout the habitat. Plant species along the border of the delineated wetland area included wormwood (Artemisia dracunculus), Louisiana sagewort, and New Mexico thistle (Cirsium neomexicanum). Plants observed in the upland areas surrounding the drainage channels included green rabbitbrush, needle-leaf rabbitbrush (Ericameria teretifolia), eastern Mojave buckwheat, mormon tea, Cooper's heathgoldenrod (Ericameria cooperi), and Mexican bladdersage (Salazaria mexicana). An approximate $40-\mathrm{m}^{2}\left(430-\mathrm{ft}^{2}\right)$ area near the cottonwood trees had accumulated deep soils, but the soils were not saturated. Roots from the trees appeared to extend into the adjacent spring pool area where saturated soils were present. A small pile of runoff debris in the dry wash near the cottonwoods suggested previous surface water flow through this area. The surface area delineated by hydrophytic plants was estimated to be approximately $130 \mathrm{~m}^{2}\left(1,399 \mathrm{ft}^{2}\right)$ (Table 5-1, Section 5.0). 


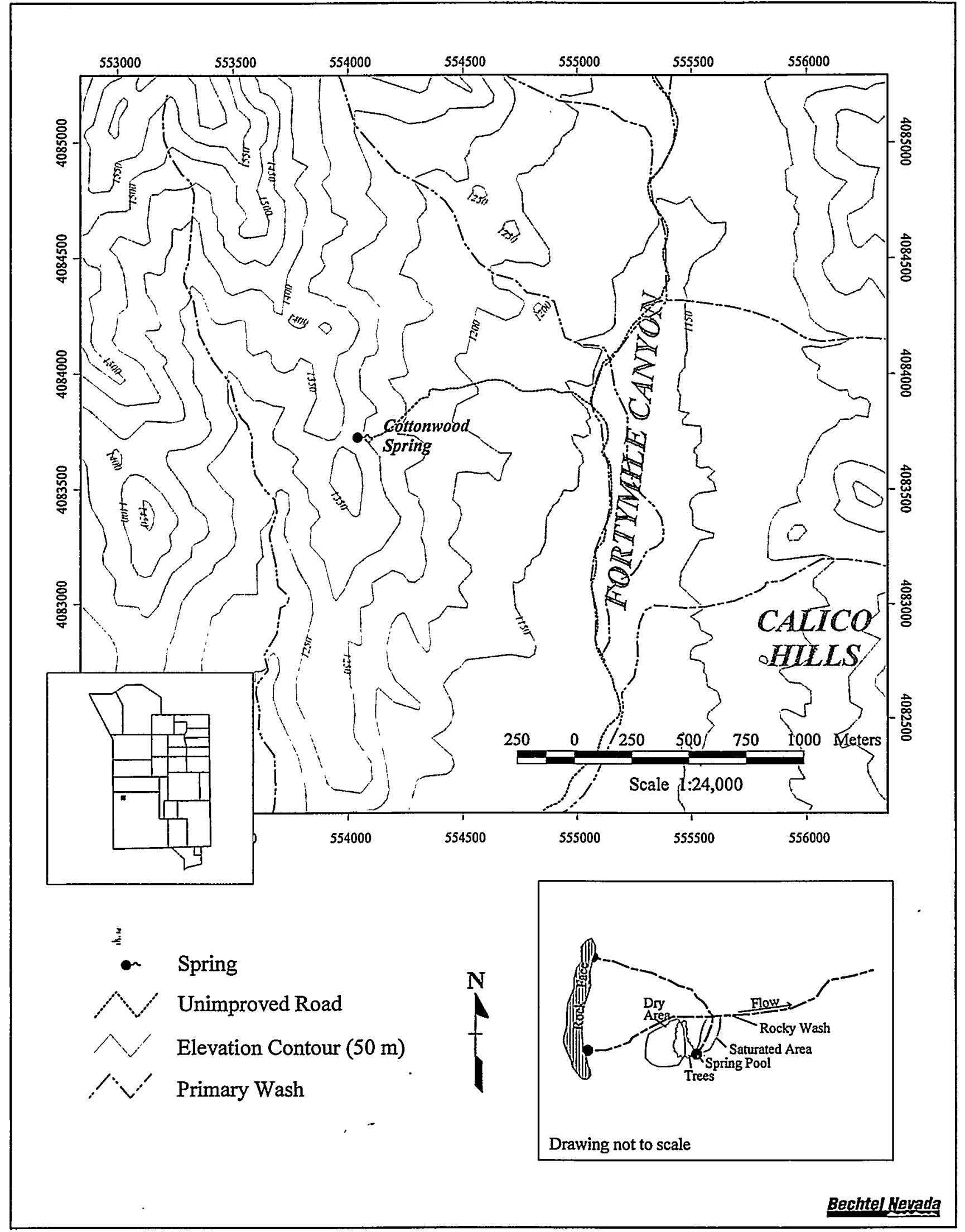

Figure 4-4 Location and sketch of Cottonwood Spring 


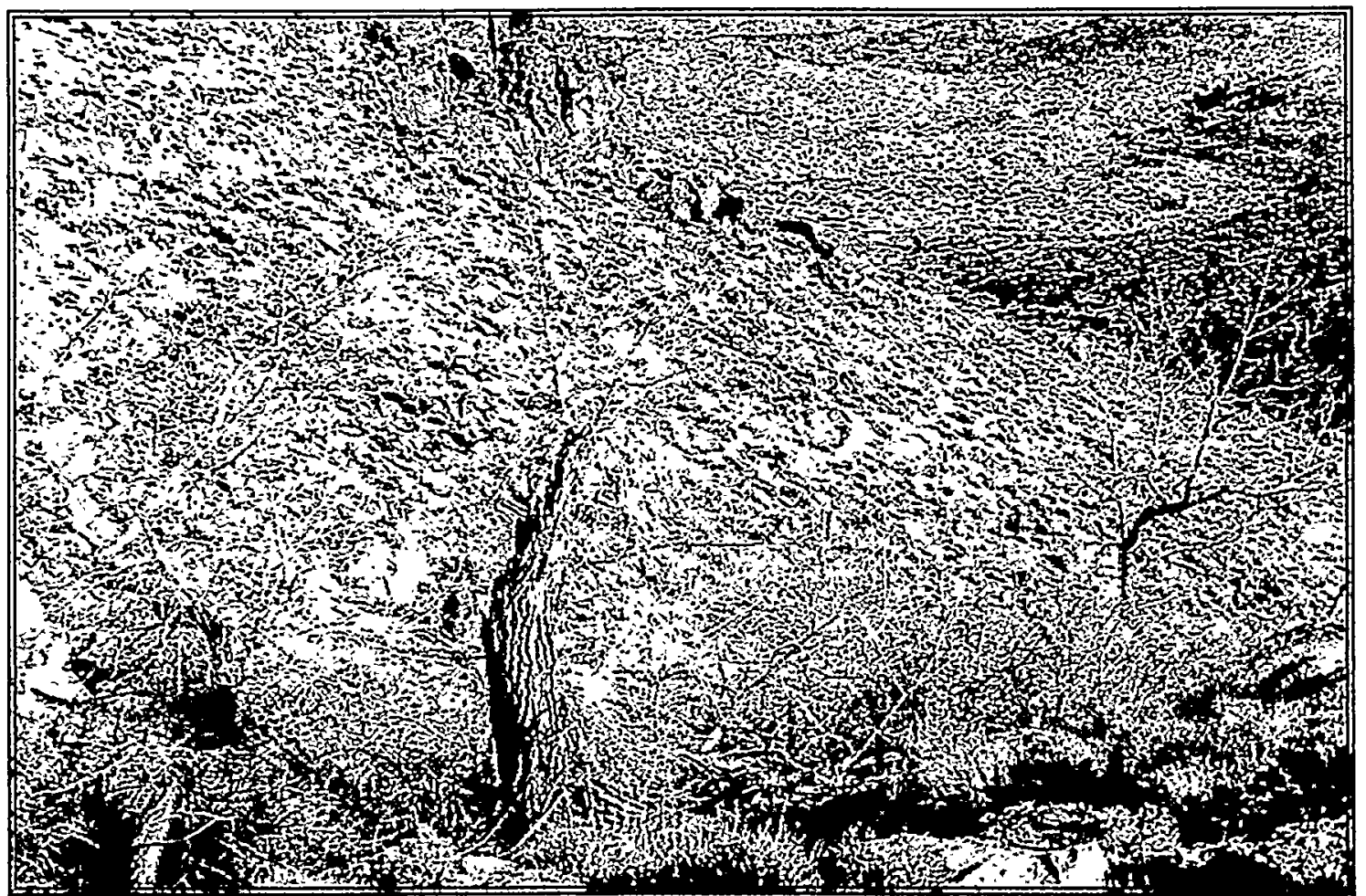

Photo 4-11. Cottonwood Spring looking northeast on January 8, 1997. (WS347-11.TIF)

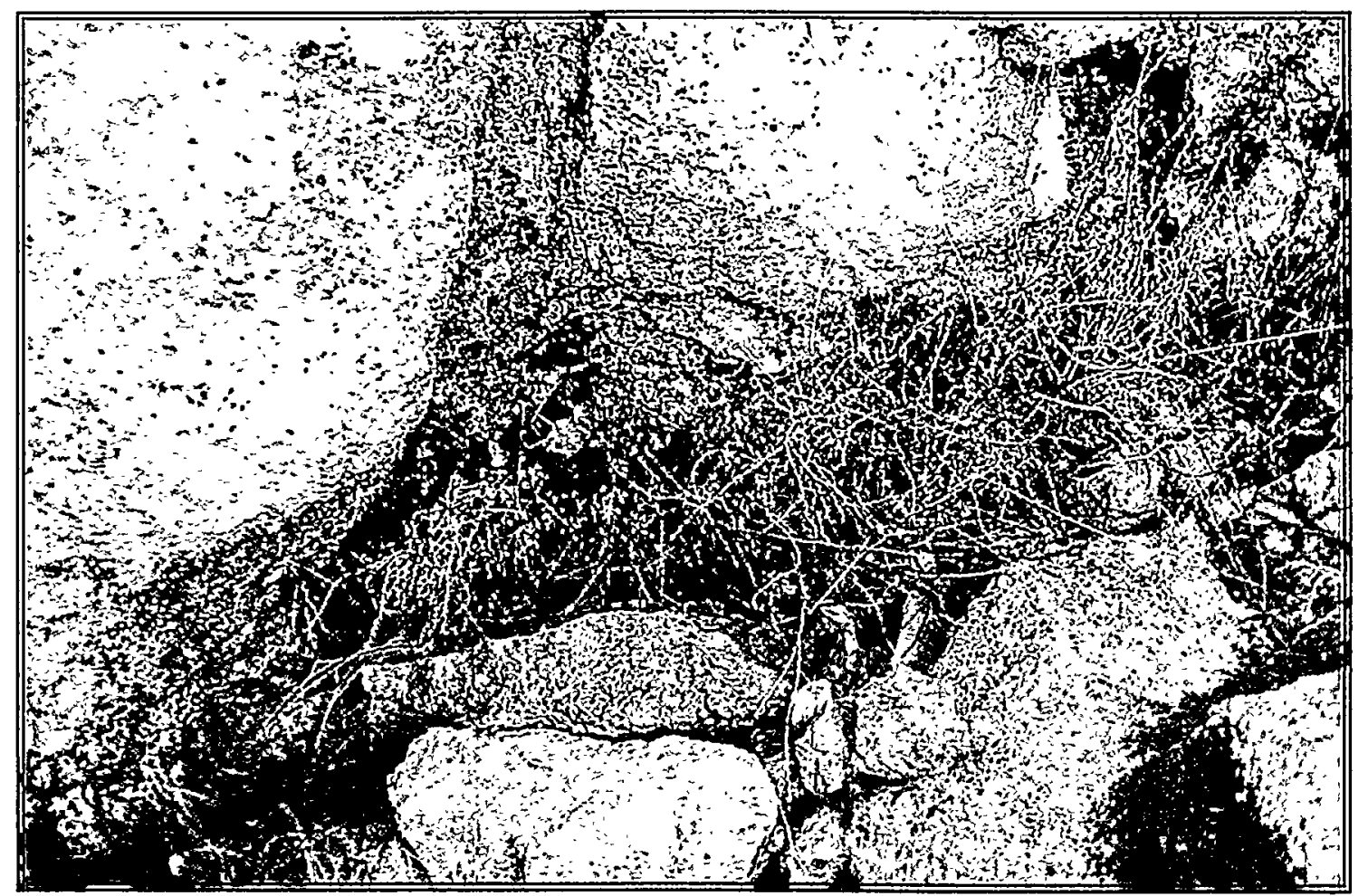

Photo 4-12. Vegetation on rock face at Cottonwood Spring on January 8, 1997. (WS347-09.TIF) 


\section{Habitat: Drainage Channel}

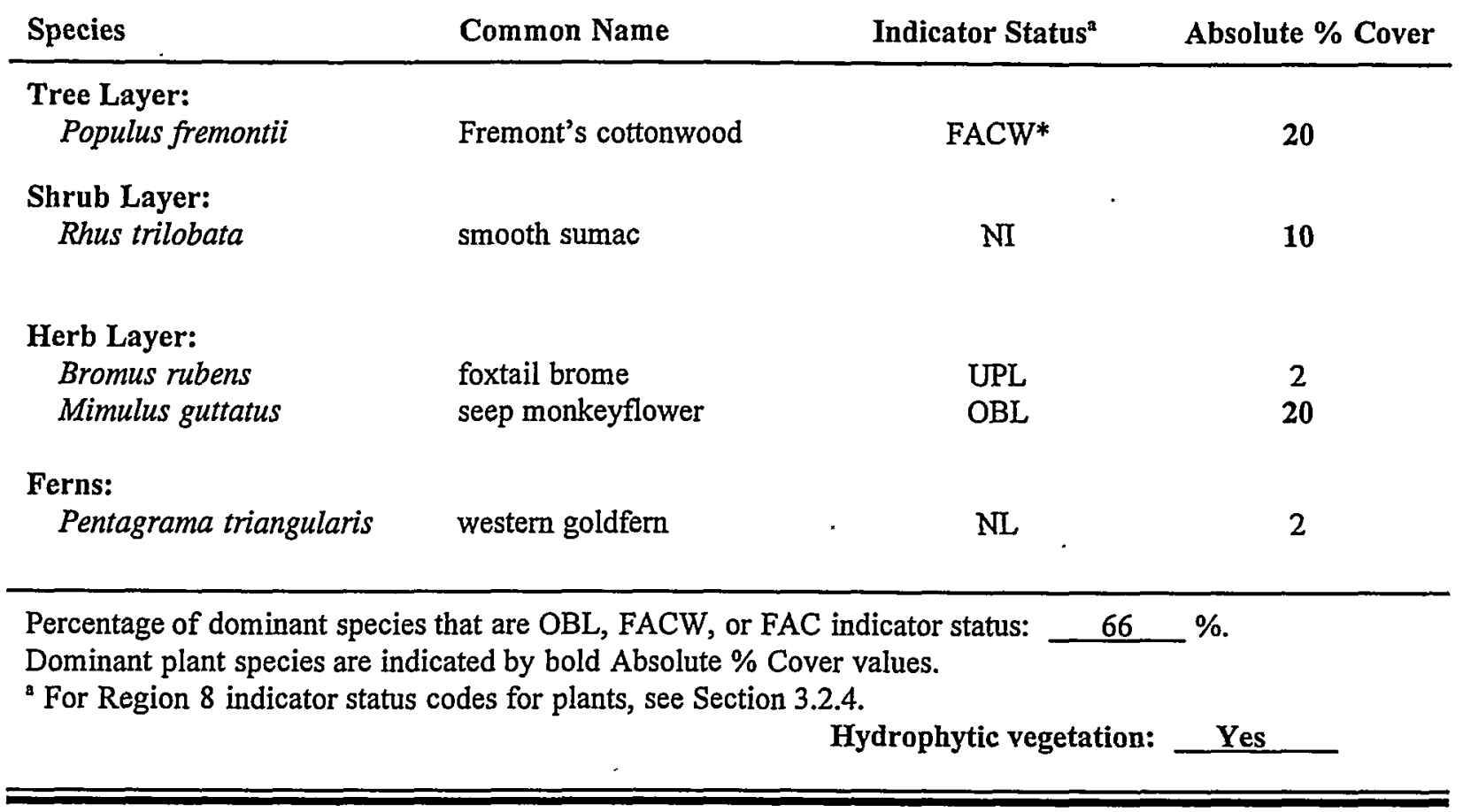

\subsubsection{Wetland Hydrology and Water Quality}

Areas observed to have field indicators of wetland hydrology included the spring pool, a seep area below the spring pool, and intermittently wet areas within two drainage channels below the spring pool. The spring pool, about $1 \mathrm{~m}^{2}\left(10.8 \mathrm{ft}^{2}\right)$ in area and about $25 \mathrm{~cm}(10$ in) deep, was located just below the three cottonwood trees (Photo 4-13). Growths of filamentous algae were abundant in the spring pool. Below the spring pool is a seep area. Water also flows from two other locations (Figure 4-4) along a rock face (Photo 4-12) covered with mosses, ferns, and other hydrophytic plants. Most inundated areas in the habitat were shallow, about $3 \mathrm{~cm}(1 \mathrm{in})$ deep. The seep area and two channels near the spring had surface flow in December 1996 and formed a confluence about $70 \mathrm{~m}(230 \mathrm{ft})$ below the cliff face (Figure 4-4). These channels cut through rock and formed pools of

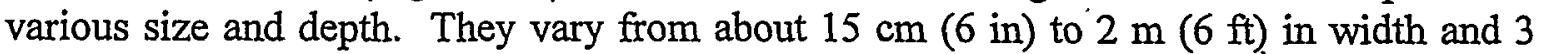
$\cdot \mathrm{cm}(1 \mathrm{in})$ to about $25 \mathrm{~cm}$ (10 in) in depth (Photo 4-14). The flow rate measured in December 1996 in the wash below the confluence of the two channels was approximately $1 \mathrm{\ell} / \mathrm{min}(0.3 \mathrm{gal} / \mathrm{min}$ ) (Table 5-1, Section 5.0). The area of surface inundation was about $90 \mathrm{~m}^{2}\left(969 \mathrm{ft}^{2}\right)$. Water quality data were taken in January 1997 and are presented in Table 5-2 (Section 5.0). 


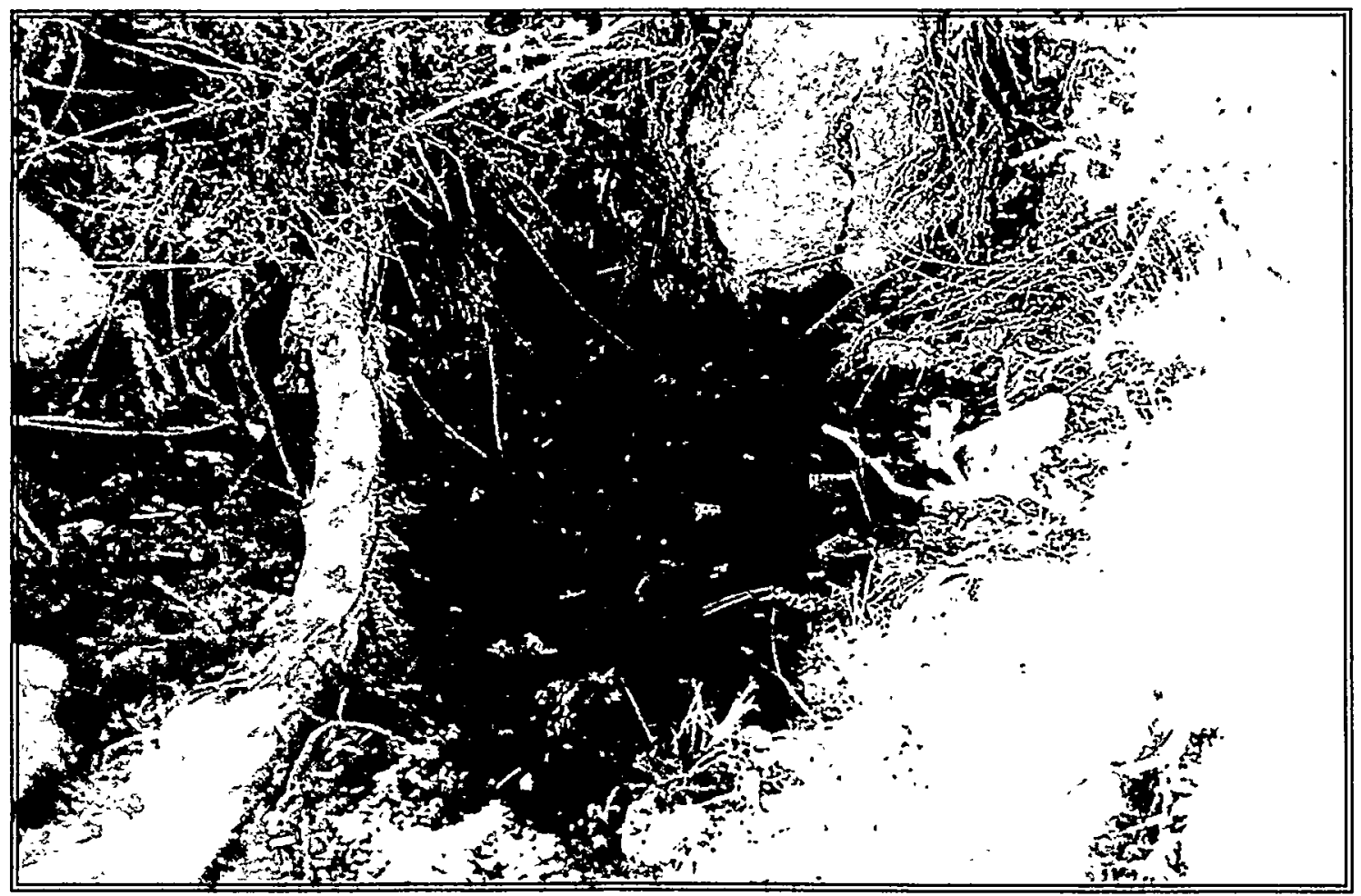

Photo 4-13. Spring pool at Cottonwood Spring on January 8, 1997. (WS347-08.TIF)

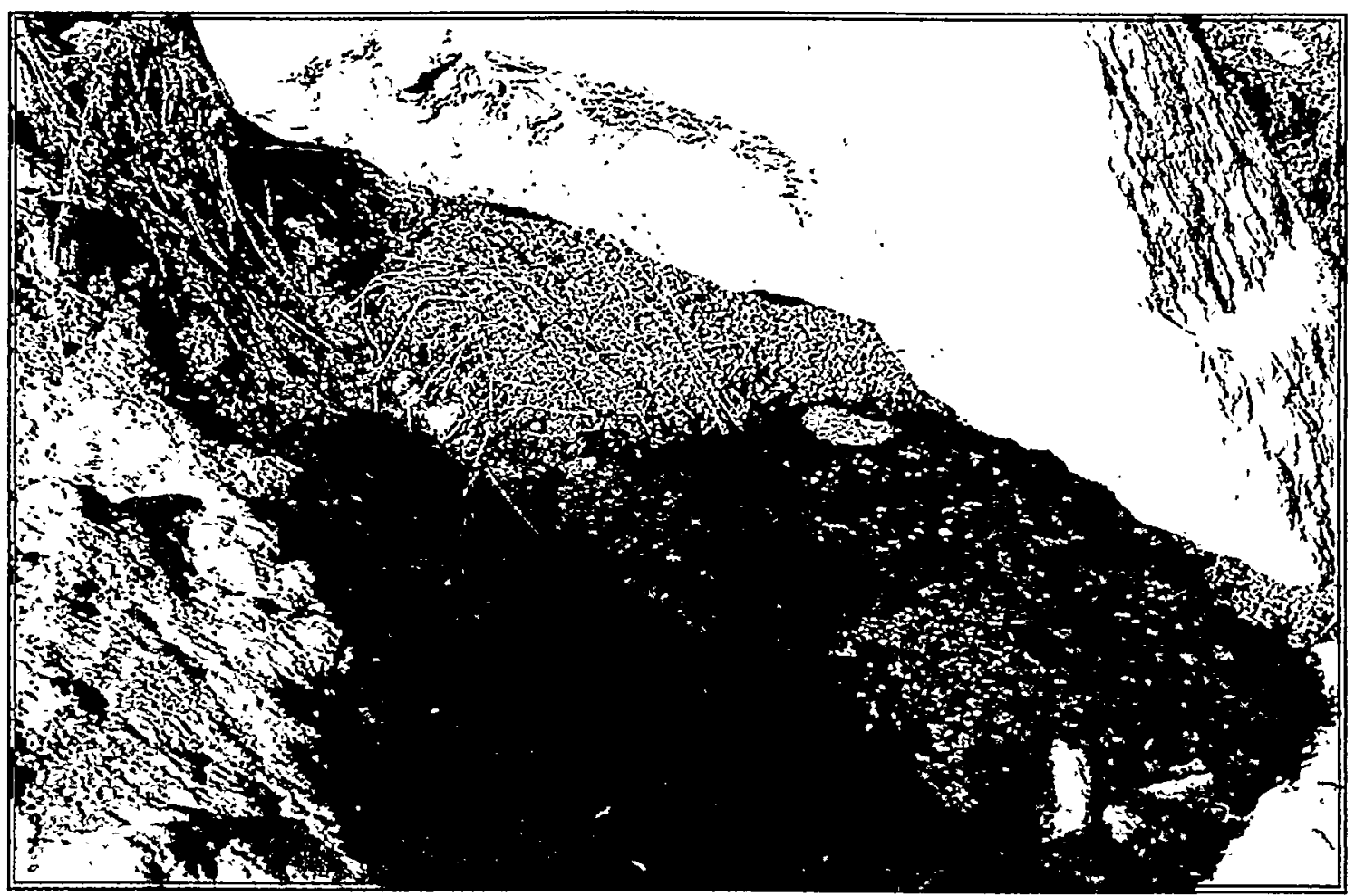

Photo 4-14. Pool in rocky wash at Cottonwood Spring on January 8, 1997. (WS347-05.TIF) 


\subsubsection{Hydric Soils}

Hydric soils appear to be present at Cottonwood Spring and were confined to the seep below the spring pool, and in pools and saturated soils within the two drainage channels. These soils appeared to be saturated for at least seven days during the growing season, indicating the presence of hydric soils.

An area with deeper soils directly under the three cottonwood trees did not appear to have

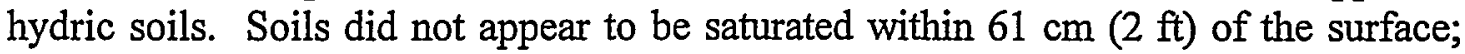
however, no soil pits were dug at this site.

\subsubsection{Determination of Jurisdictional Status}

Several areas around Cottonwood Spring would probably be considered jurisdictional wetlands because they have field indicators of all three required wetland parameters: hydrophytic vegetation, wetland hydrology, and hydric soils. These areas include the spring pool, the seep or saturated area below the spring pool, and intermittent pools or wet areas within the two drainage channels located about $70 \mathrm{~m}$ (230 ft) upslope and about 150 $\mathrm{m}(492 \mathrm{ft})$ downslope from the confluence of the drainage channels.

\subsubsection{Wildlife Use}

No previous monitoring of wildlife use has been conducted at this spring. Little is known about wildlife use of the spring. Mule deer scat was observed in the vicinity of the spring at the time of the wetland survey. Aquatic invertebrates observed in the spring pool in December 1996 included crustaceans (ostracods and copepods).

\subsubsection{Coyote Spring}

\subsubsection{Site Description and Historical Use}

Coyote Spring (Figure 4-5) is located about $3 \mathrm{~km}$ (2 mi) southeast of Hampel Hill and approximately 3 to $5 \mathrm{~km}$ ( 2 to $3 \mathrm{mi}$ ) southwest of Frenchman Flat. The site (Photo 4-15) is within a wash in an area that is distant from any roads and shows no evidence of disturbạnce by man.

\subsubsection{Hydrophytic Vegetation}

A wetland vegetation survey of Coyote Spring was conducted on September 4, 1996. Coyote Spring consists of three seep areas (Figure 4-5) that either currently or previously supported wetland vegetation. In September, only one of these three areas was dominated by hydrophytic vegetation (Table 4-6, Photo 4-16). This area was the furthest downslope and was dominated by inland saltgrass (Distichlis spicata), a wetland plant species which covered a surface area of about $160 \mathrm{~m}^{2}\left(1,722 \mathrm{ft}^{2}\right)$. A second seep area is about $40 \mathrm{~m}^{2}$ $\left(430 \mathrm{ft}^{2}\right)$ in size and is located on the adjacent hill side. It was dominated by common kochia (Kochia scoparia) and soils there were moist and dark-colored. No vegetation occurred on the third area which had dark-colored and moist soils and was located west of. the other seep areas. 


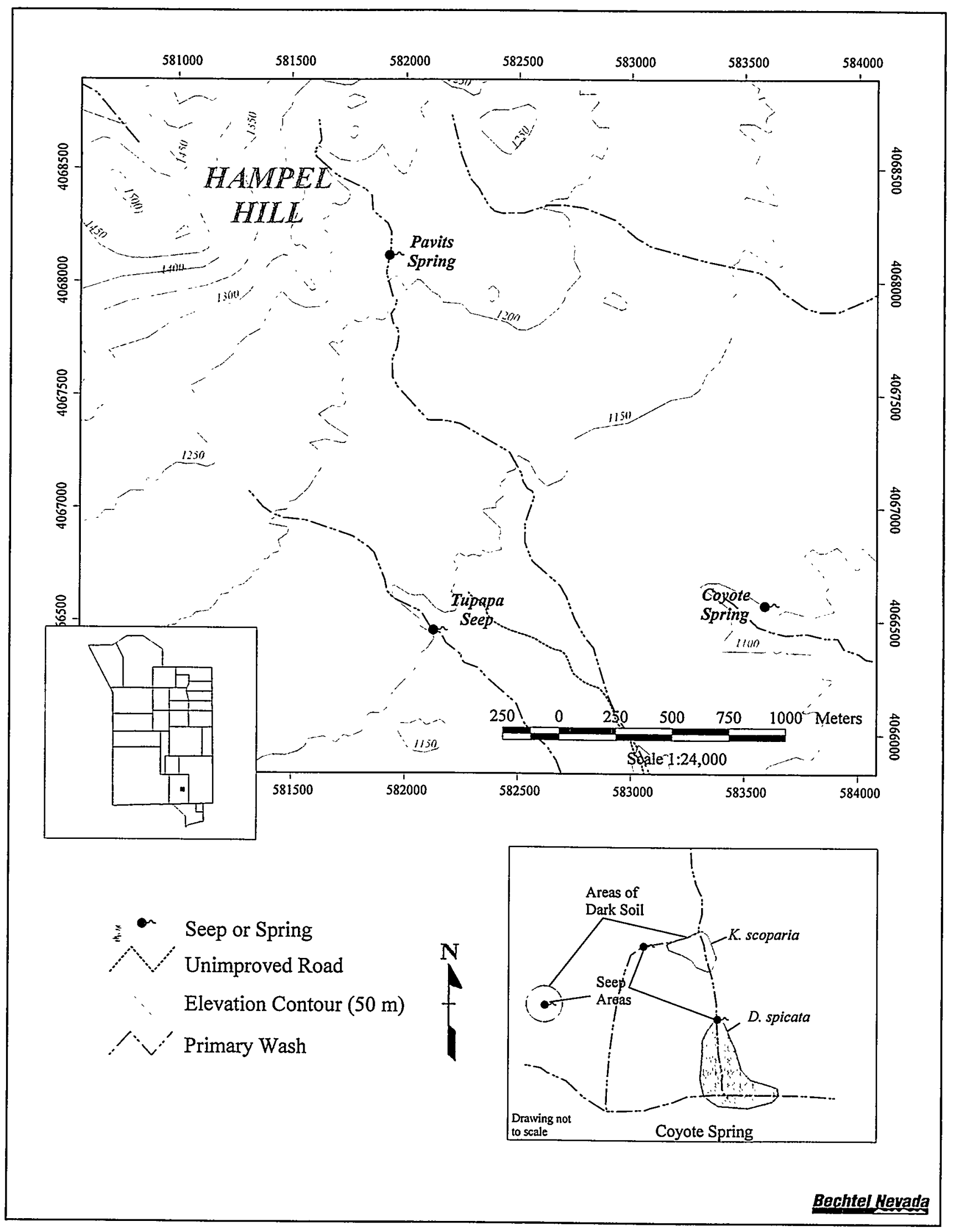

Figure 4-5 Location and sketch of Coyote Spring, Pavits Spring, and Tupapa Seep and sketch of Coyote Spring 


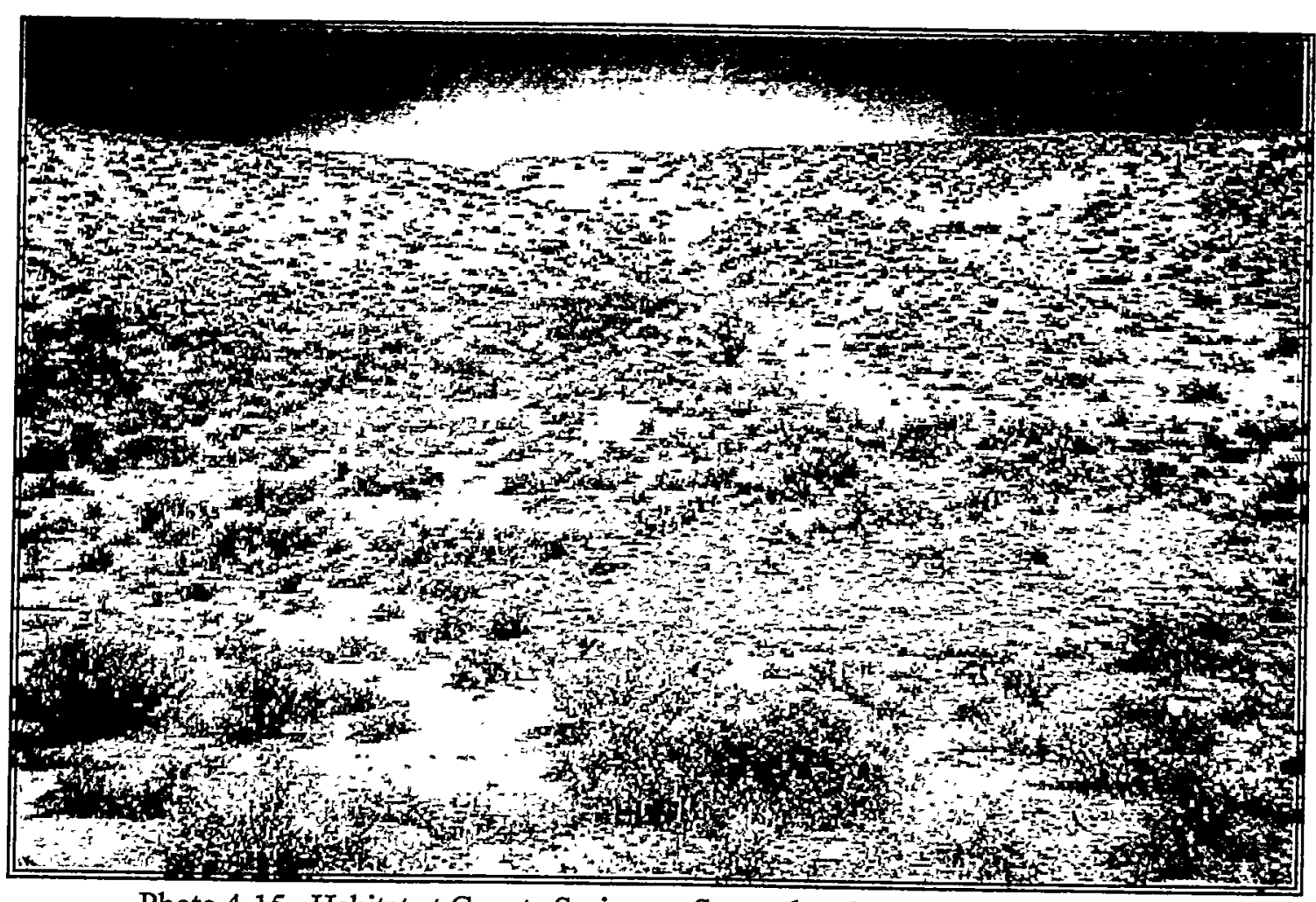

Photo 4-15. Habitat at Coyote Spring on September 4, 1996. (WS503-02.TIF)

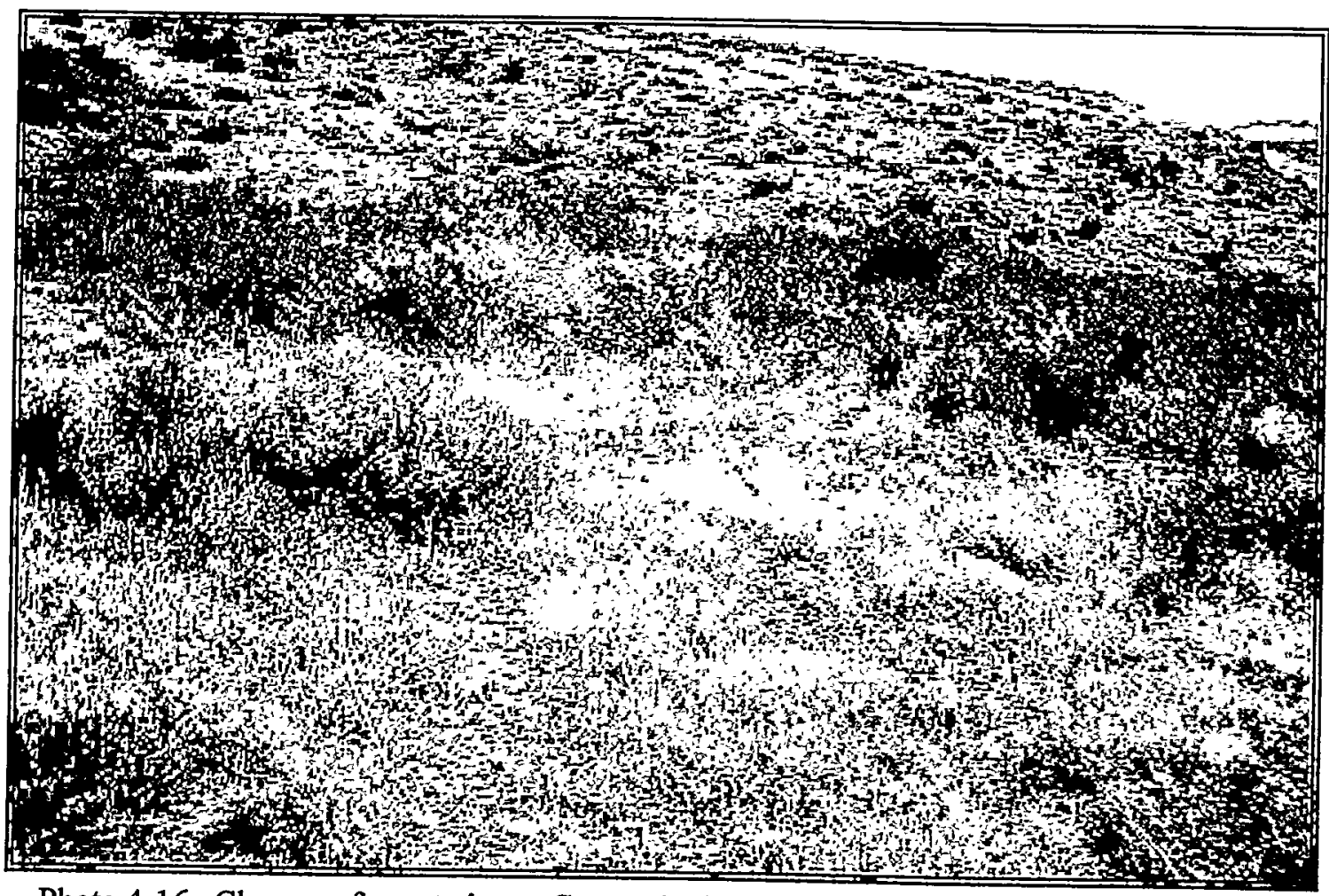

Photo 4-16. Closeup of vegetation at Coyote Spring on September 4, 1996. (WS504-01.TIF) 


\begin{tabular}{|c|c|c|c|}
\hline Species & Common Name & Indicator Status ${ }^{\mathrm{a}}$ & Absolute $\%$ Cover \\
\hline \multicolumn{4}{|l|}{$\begin{array}{l}\text { Tree Layer: } \\
\text { no species }\end{array}$} \\
\hline \multicolumn{4}{|l|}{$\begin{array}{l}\text { Shrub Layer: } \\
\text { no species }\end{array}$} \\
\hline $\begin{array}{l}\text { Herb Layer: } \\
\quad \text { Distichlis spicata }\end{array}$ & inland saltgrass & $\mathrm{FAC}+*$ & 60 \\
\hline
\end{tabular}

Percentage of dominant species that are OBL, FACW, or FAC indicator status: $100 \%$.

Dominant plant species are indicated by bold Absolute \% Cover values.

${ }^{a}$ For Region 8 indicator status codes for plants, see Section 3.2.4.

Hydrophytic vegetation: Yes

Other upland plants in the area included shadscale saltbush (Atriplex confertifolia), largeflower suncup (Cane Spring evening primrose), bottlebrush squirreltail (Elymus elymoides), and basin wildrye.

\subsubsection{Wetland Hydrology and Water Quality}

The only area observed to have field indicators of wetland hydrology was the seep area farthest downslope, although no standing water was observed at this site. Seasonal water availability at Coyote Spring is poorly understood; however, the presence of facultative wetland vegetation (inland saltgrass) and dark-colored soils are evidence of prior wetland hydrology. The unvegetated area of $6 \mathrm{~m}^{2}\left(65 \mathrm{ft}^{2}\right)$ located in the wash also had darkcolored and wet surface soils. Observations made in September 1996 may not be representative of conditions during wetter years. No water quality data were collected at the time of the field survey.

\subsubsection{Hydric Soils}

Field indicators for hydric soils appeared to be present in the area dominated by inland saltgrass (i.e., the seep area furthest down slope). These indicators included dark-colored soils which appeared to have been saturated for periods of at least seven days during the growing season. No soil pits were dug. The other two seep areas also had dark-colored moist soils, but did not have evidence of saturated soils.

\subsubsection{Determination of Jurisdictional Status}

Coyote Spring has one area that would probably qualify as a jurisdictional wetland (the area dominated by inland saltgrass) because it had all three required parameters: 
hydrophytic vegetation, wetland hydrology, and hydric soils. Field indicators from the other two areas suggest that these areas could also support hydrophytic vegetation after a period of normal precipitation when seep flows would be higher. However, at the time of the survey, these other two seep areas did not have field indicators that would meet criteria to be considered jurisdictional wetlands.

\subsubsection{Wildlife Use}

Coyotes, mule deer, and game birds such as Gambel's quail are common vertebrates in the area and likely use the seep areas during winter and spring when flow rates are expected to be highest. No previous monitoring of wildlife use has been conducted at these seeps. No birds or other wildlife signs were observed at the seeps during limited observations conducted as part of the wetland survey.

\subsubsection{Fortymile Canyon Tanks}

\subsubsection{Site Description and Historical Use}

Several unnamed tanks and a small seep, identified as "Seep" on the Topopah Spring USGS 7.5 Minute Series quadrangle map (1961), are located in a side wash about $2 \mathrm{~km}$ (1.2 mi) east of Fortymile Canyon (Figure 4-6). The tanks and seep are located in a narrow section of the canyon with steep barren slopes on either side (Photo 4-17). There is no reported evidence of human occupation or use of this site.

\subsubsection{Hydrophytic Vegetation}

A wetland vegetation survey of Fortymile Canyon Tanks was conducted on February 12, 1997. Most of the tanks at this site have no vegetation associated with them. One area did have some limited soil and vegetation (Photo 4-18). Cover on this area was low at approximately 11 percent (Table 4-7). Louisiana sagewort and foxtail brome dominated the site. One other species, seep monkeyflower, occurred at the site, but averaged only 1 percent cover. No other species were found at this site. Because only 33 percent of the species identified from the observation point were classified as obligate or facultative wetland species, the site would be classified as not having hydrophytic vegetation. Plant species observed in the upland area were Stansbury cliffrose (Purshia stansburiana), skunkbush sumac (Rhus trilobata), green rabbitbrush, roundleaf rabbitbrush (Ericameria teretifolia), mormon tea, Nevada jointfir (Ephedra nevadensis), and big sagebrush.

\subsubsection{Hydrology}

This site consists of seven water tanks located in bedrock and a small seep at the head of the tanks. The tanks are located in a narrow rocky wash and they vary in size. The two largest ones were approximately $1 \mathrm{~m}$ by $3 \mathrm{~m}$ ( $3 \mathrm{ft}$ by $9 \mathrm{ft}$ ), and the water in this tank was about $20 \mathrm{~cm}(8 \mathrm{in})$ deep. All tanks were filled with water at the time of the survey in February 1997. The estimated total area of surface water was $8 \mathrm{~m}^{2}\left(86 \mathrm{ft}^{2}\right)$ (Table 5-1, Section 5.0). Bedrock is exposed about $30 \mathrm{~m}(98 \mathrm{ft})$ up both sides of the canyon, which 

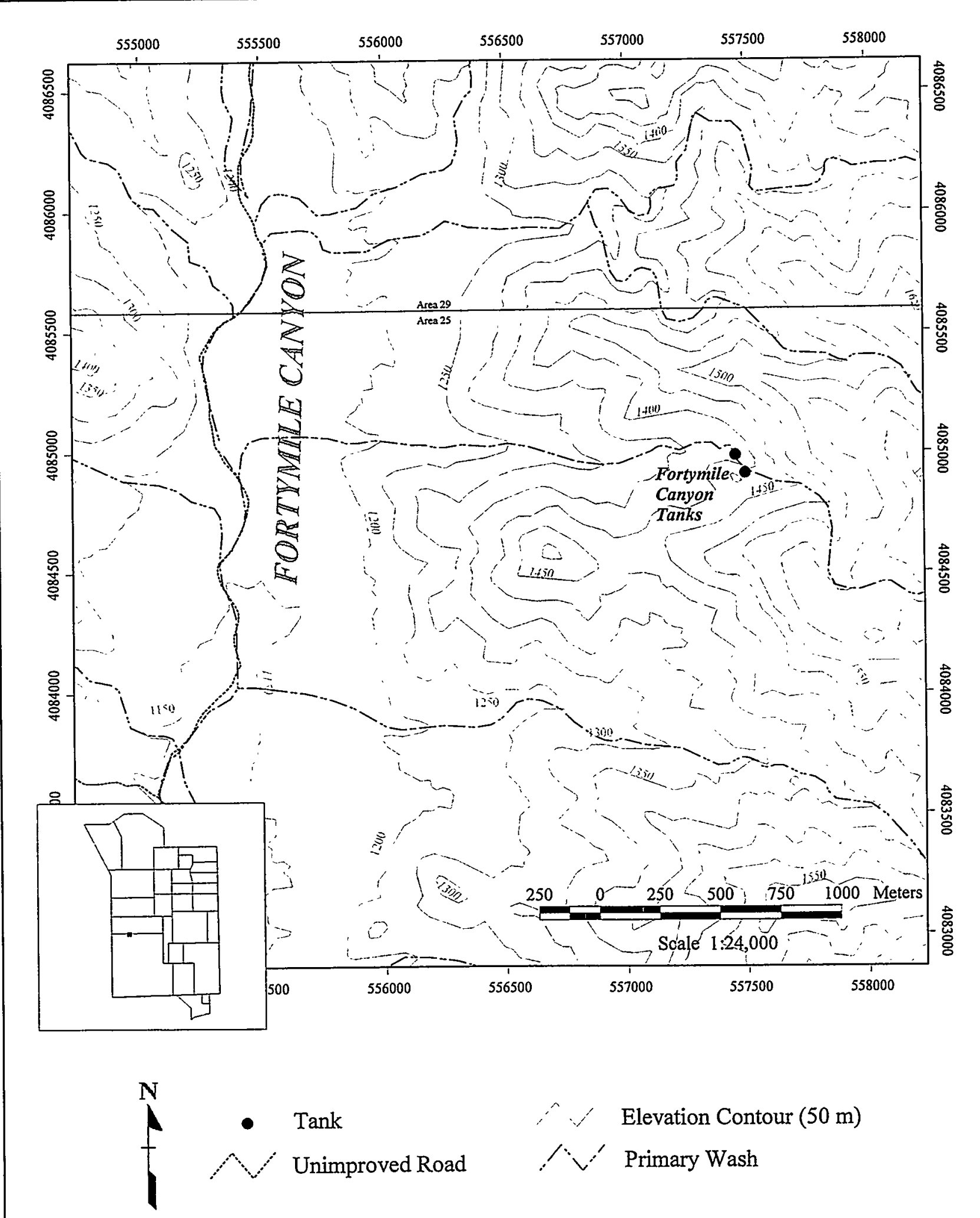

Bechtel Nevada 


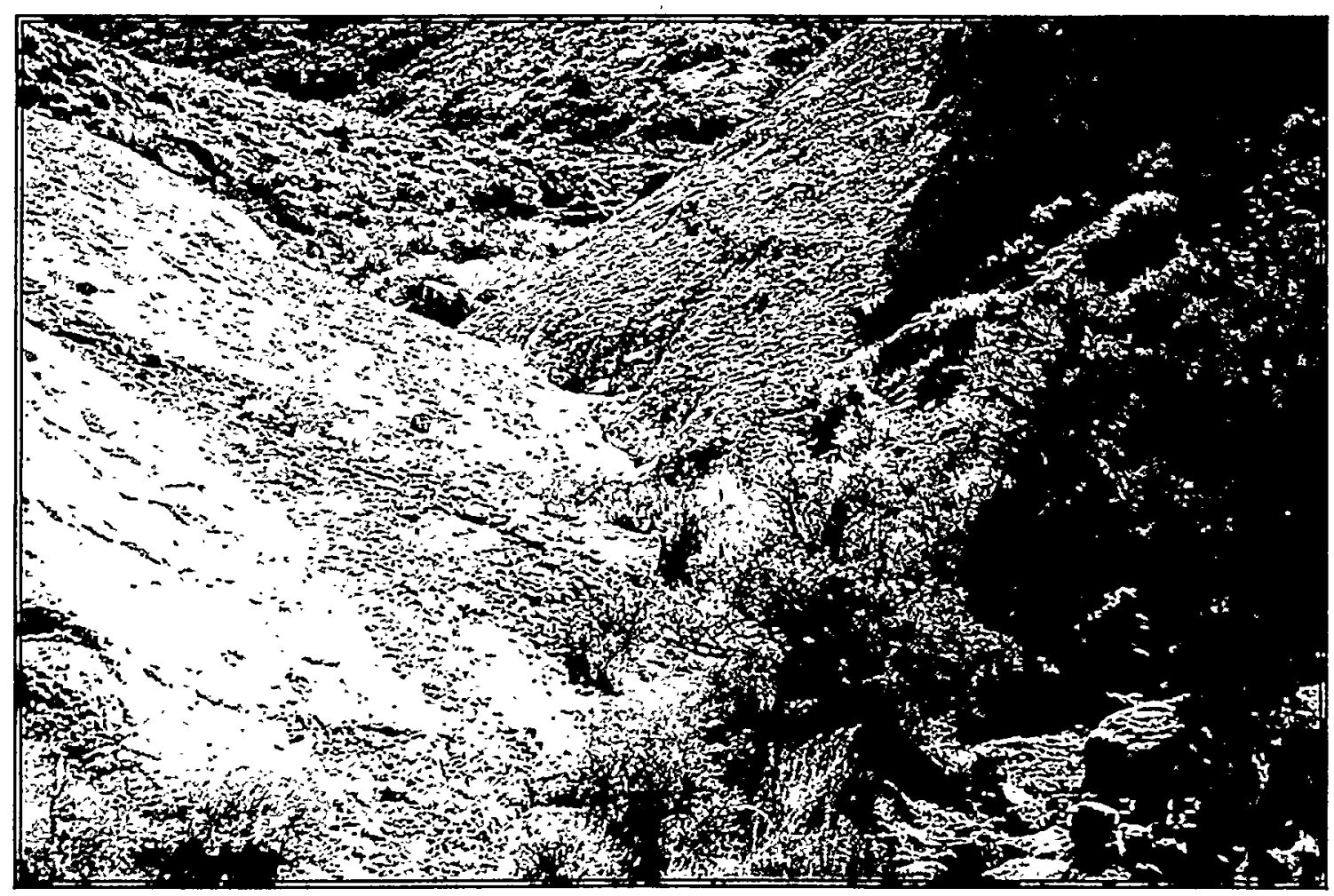

Photo 4-17. Habitat at Fortymile Canyon Tanks looking east on February 12, 1997. (40MILE1.TIF)

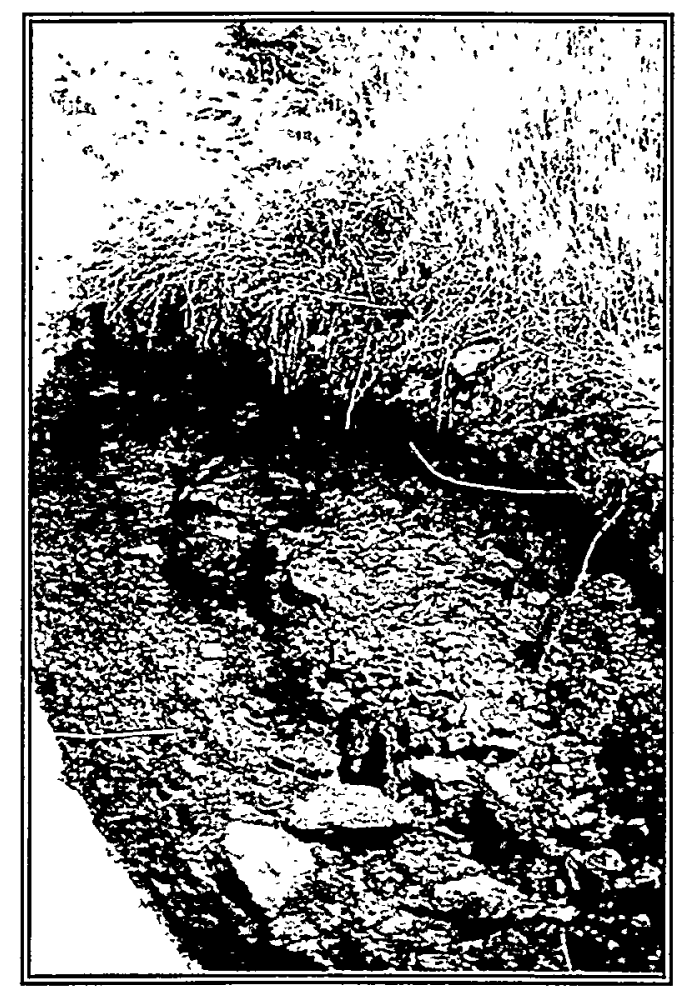

Photo 4-18. Vegetation at Fortymile

Canyon Tanks on February 12, 1997. (40MILE2.TIF) 
Table 4-7 Fortymile Canyon Tanks wetland vegetation as surveyed on February 12, 1997

\begin{tabular}{llll}
$\begin{array}{l}\text { Habitat: Third Tank Downslope from Seep } \\
\text { Common Name }\end{array}$ & Indicator Status $^{\mathbf{a}}$ & Absolute \% Cover $^{\text {Species }}$ \\
\hline $\begin{array}{l}\text { Tree Layer: } \\
\text { no species }\end{array}$ & & & \\
Shrub Layer: & & & \\
no species & & & 5 \\
Herb Layer: & & FACU & 5 \\
Artemisia ludoviciana & Louisiana sagewort & UPL & 1 \\
$\begin{array}{l}\text { Bromus rubens } \\
\text { Mimulus guttatus }\end{array}$ & foxtail brome & OBL & \\
\hline
\end{tabular}

Percentage of dominant species that are OBL, FACW, or FAC indicator status: $33 \%$.

Dominant plant species are indicated by bold Absolute \% Cover values.

${ }^{a}$ For Region 8 indicator status codes for plants, see Section 3.2.4.

Hydrophytic vegetation:

hastens runoff and aids in the collection of water in the tanks on the canyon bottom. The tanks appear to collect surface runoff from precipitation and from water flow from the seep. At the time of the survey, water was seeping from under a large boulder at the head of the tanks at a measured rate of $0.2 \mathrm{l} / \mathrm{min}(0.05 \mathrm{gal} / \mathrm{min})$. No water quality measurements were taken.

\subsubsection{Hydric Soils}

This site occurs primarily on bedrock which has no soil development. However, one small $\left(4 \mathrm{~m}^{2}\left[43 \mathrm{ft}^{2}\right]\right)$ area had shallow soils which appeared to be saturated for at least seven days during the growing season, indicating the presence of hydric soils.

\subsubsection{Jurisdictional Wetland Determination}

This site would not be considered a jurisdictional wetland because it lacks hydrophytic vegetation.

\subsubsection{Wildlife Use}

Little is known of wildlife use of this water source, although mule deer and coyotes are common in the area and their scat were observed in the adjacent wash area. During the survey, three golden eagles were observed soaring in the canyon above the tanks. 


\subsubsection{Gold Meadows Spring}

\subsubsection{Site Description and Historical Use}

Gold Meadows Spring is located near the base of a wash in Gold Meadows (Figure 4-7) about $3 \mathrm{~km}(2 \mathrm{mi})$ north of Rainier Mesa. It is about $100 \mathrm{~m}$ (328 ft) from Kawich Valley Road. Native American artifacts have been recovered from the Gold Meadows area, indicating there were Native American camps in the area (Worman, 1969). Gold Meadows Spring has an ephemeral pond during the spring which dries up in late summer of most years. Gold Meadows Spring appears to have been used by ranchers to water livestock in recent times. An earthen berm was constructed on the southwest side of the pond apparently to improve water storage. During years of abundant rainfall (e.g., 1992), the pond measures about $10 \times 40 \mathrm{~m}(33 \times 131 \mathrm{ft})$ (Photo 4-19).

\subsubsection{Hydrophytic Vegetation}

From the survey observation point located within the pond area, 100 percent of the dominant plants were wetland species (Baltic rush; Table 4-8) indicating that hydrophytic vegetation was present at this site. Baltic rush, a facultative wetland species, was the only plant species recorded at the Gold Meadows Spring observation point during July of 1996. This species covered an area about $45 \mathrm{~m}^{2}\left(484 \mathrm{ft}^{2}\right)$. Plant species bordering the perimeter of the pond (then dry) were primarily big sagebrush and basin wildrye. The upland habitat was dominated by the trees Utah juniper and singleleaf pinyon.

\subsubsection{Wetland Hydrology and Water Quality}

The only area observed to have field indicators of wetland hydrology was the ephemeral pond. During the winter and spring of most years, water in the pond is present (based on observations in 1989 to 1996). By summer, the pond usually dries up (Photo 4-20); however, in 1992 the pond remained all year. Although surface water was not present at the time of the field survey on July 22,1996, previous field observations of ponded water and water lines on rocks in the pond area indicated that the site had wetland hydrology: No water quality data were able to be taken at the time of the 1996 survey.

\subsubsection{Hydric Soils}

Soils at this site were shallow, about $20 \mathrm{~cm}$ ( 8 in) deep and had a dark-colored surface layer (probably because of high levels of organic matter). No evidence of soil mottling was observed. This site may have been periodically dug out by man to deepen the pond, and excavated soils were probably used to build up the existing berm. Therefore, an atypical situation occurred where hydric soils have been removed or disturbed. At the time of the survey, no saturated soils were observed (Table 5-1, Section 5.0); however, because the pond soils appeared to have been flooded or saturated for at least seven days during the growing season of each year, it seems that the site had hydric soils. This estimated area of saturated soils coincides with the area where Baltic rush was found (45 $\left.\mathrm{m}^{2}\left[484 \mathrm{ft}^{2}\right]\right)$. 


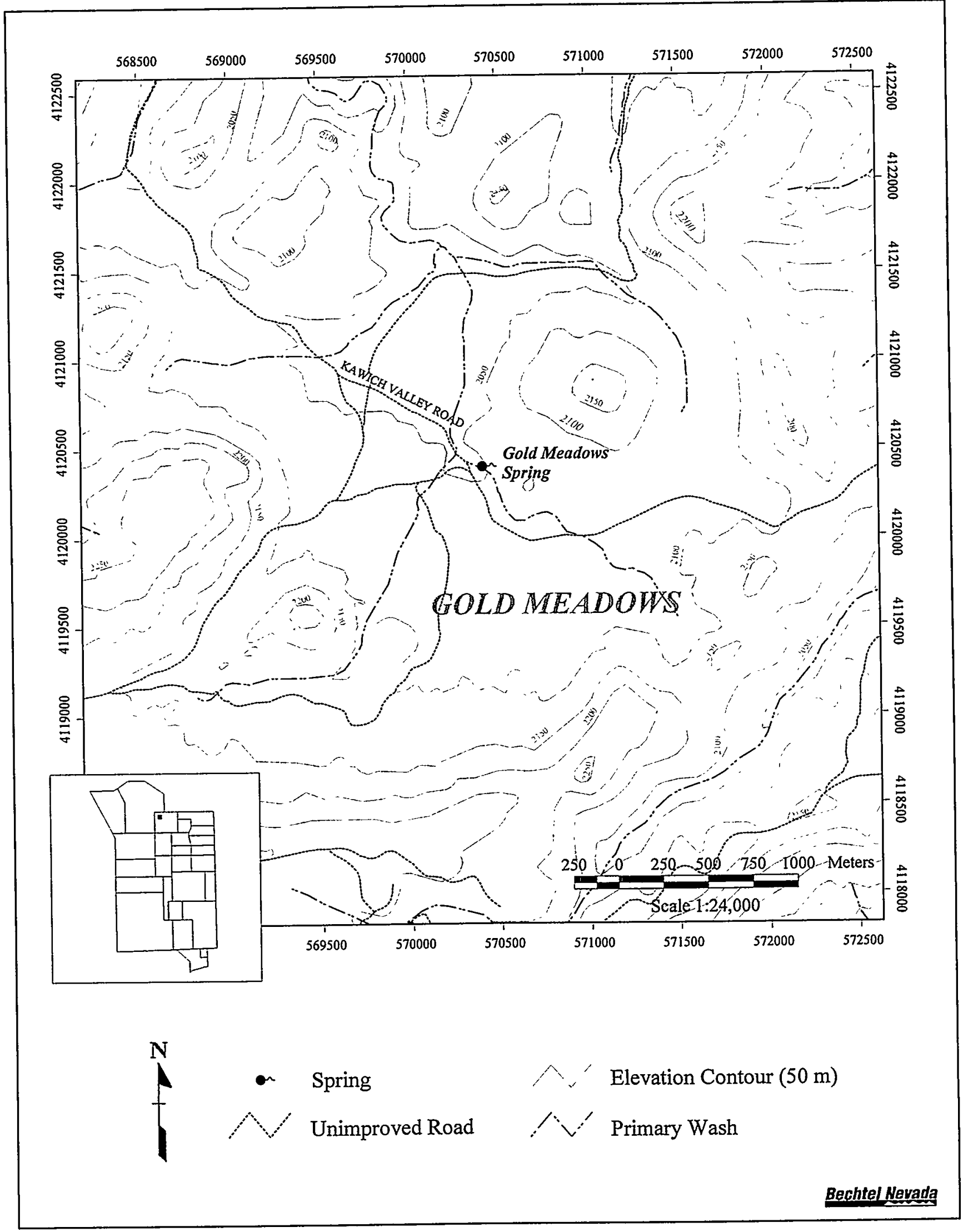

Figure 4-7 Location of Gold Meadows Spring 


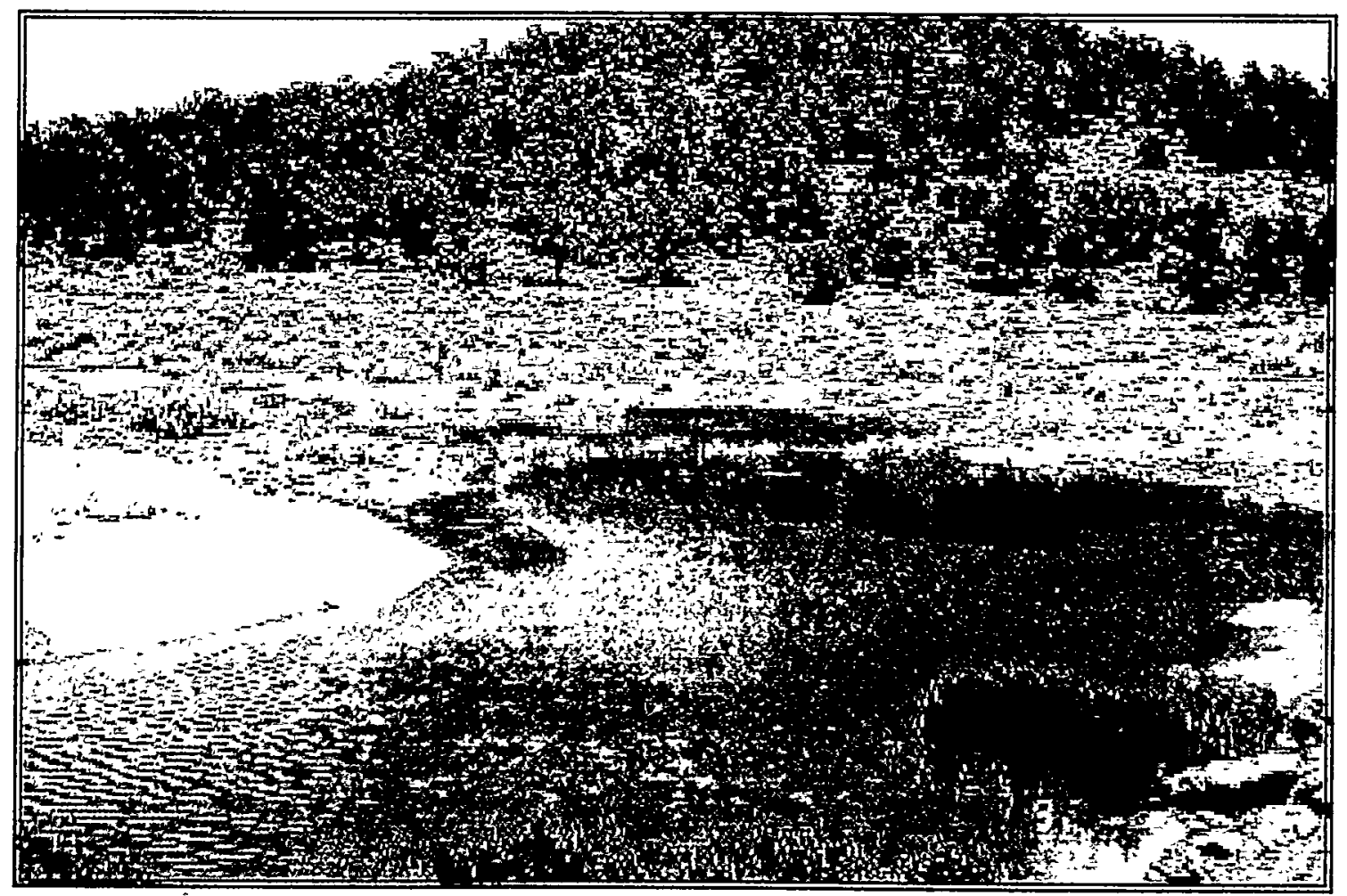

Photo 4-19 Emergent vegetation in Gold Meadows Spring on June 10, 1992 (WS310-12.TIF)

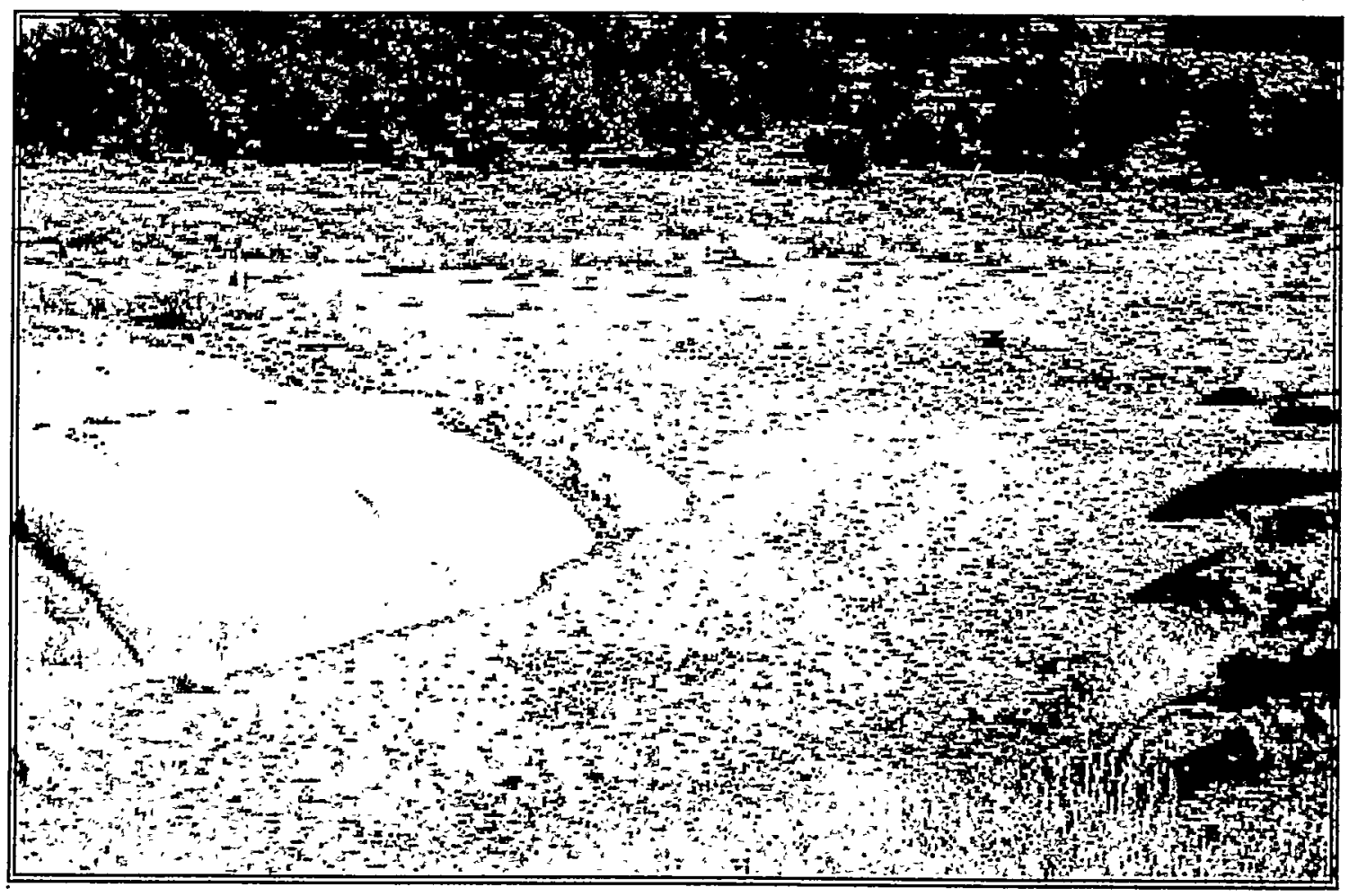

Photo 4-20 Dry pond at Gold Meadows Spring on December 10, 1990 (WS213-23.TIF) 


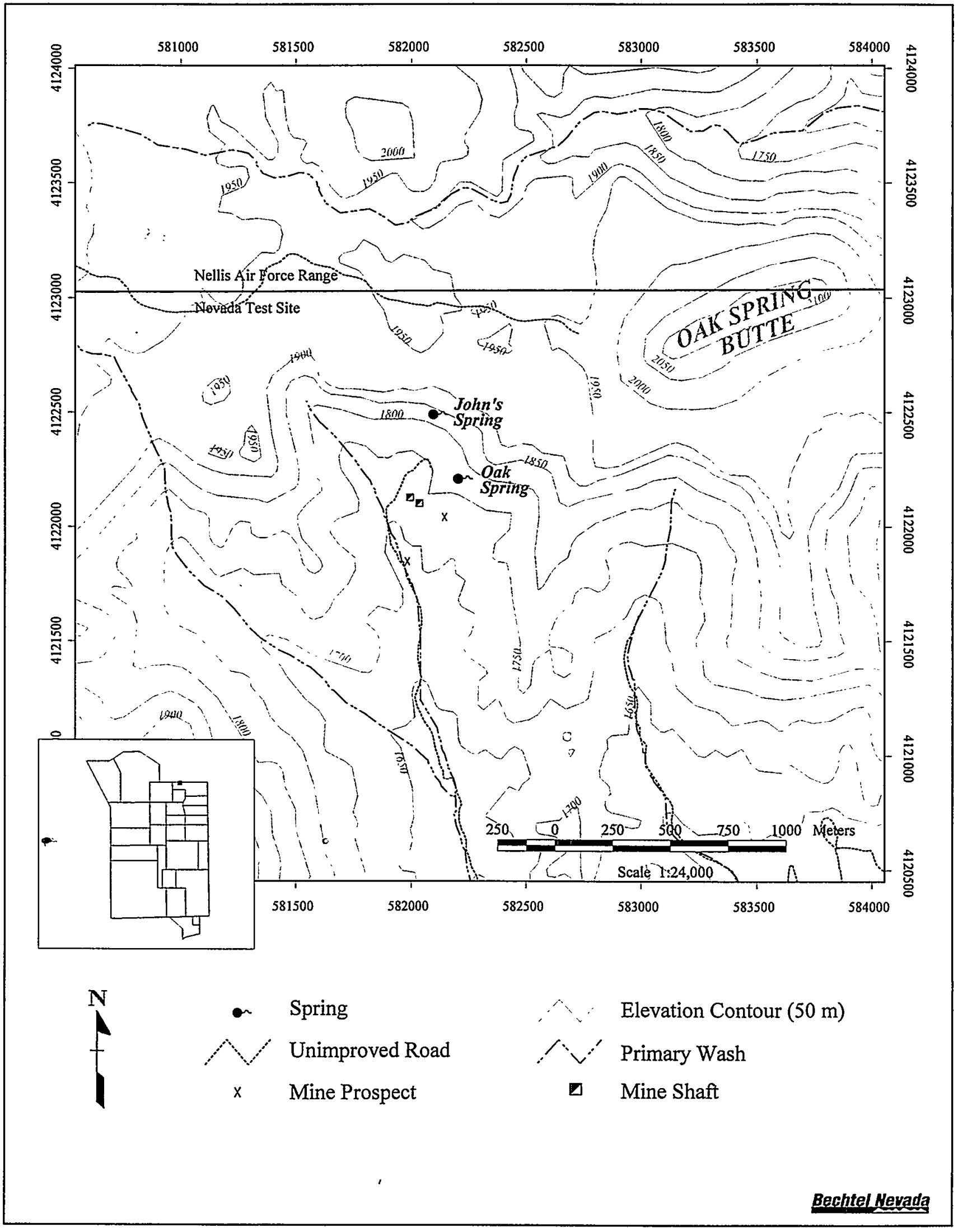

Figure 4-9 Location of Oak Spring 


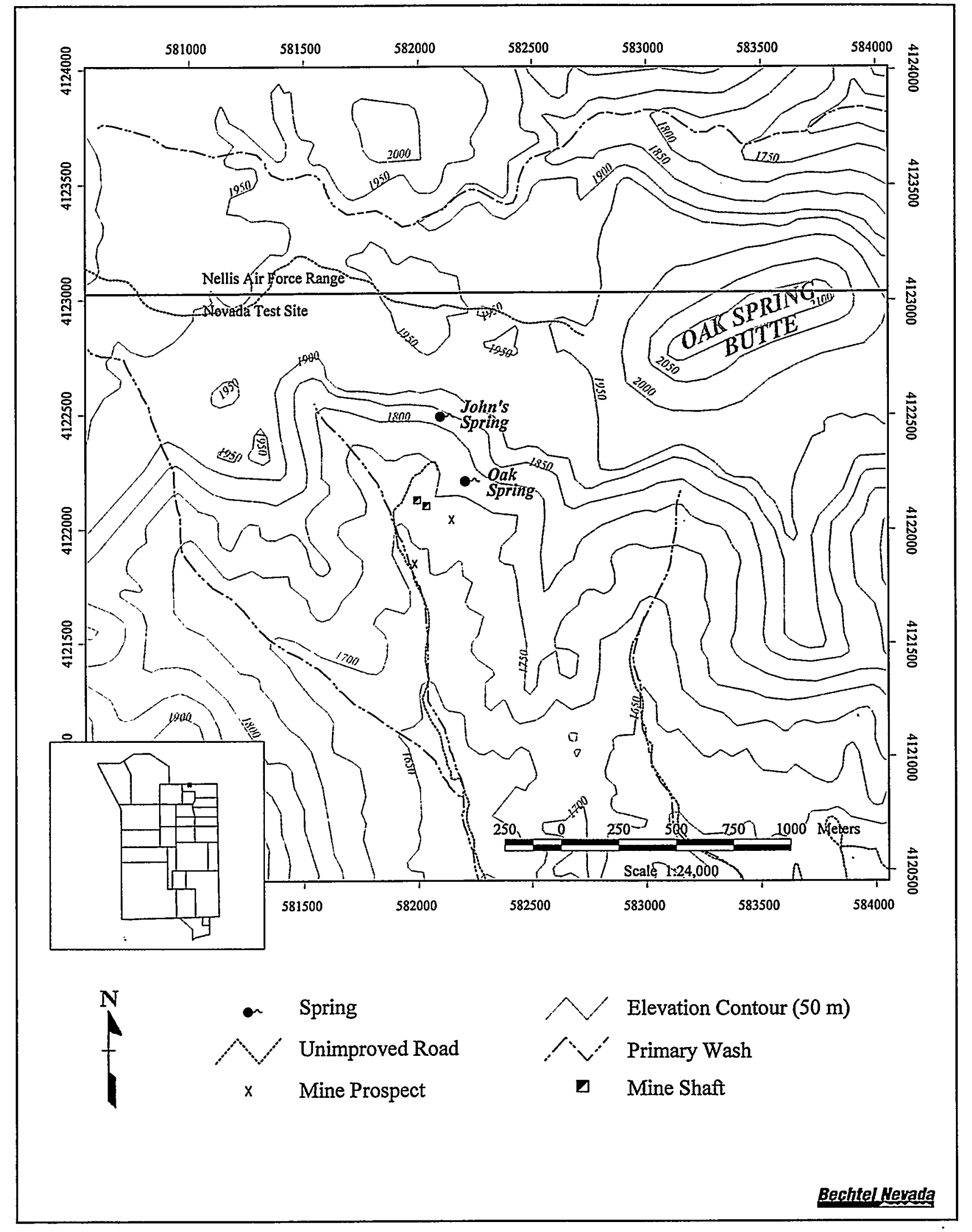

Figure 4-8 Location of John's Spring 


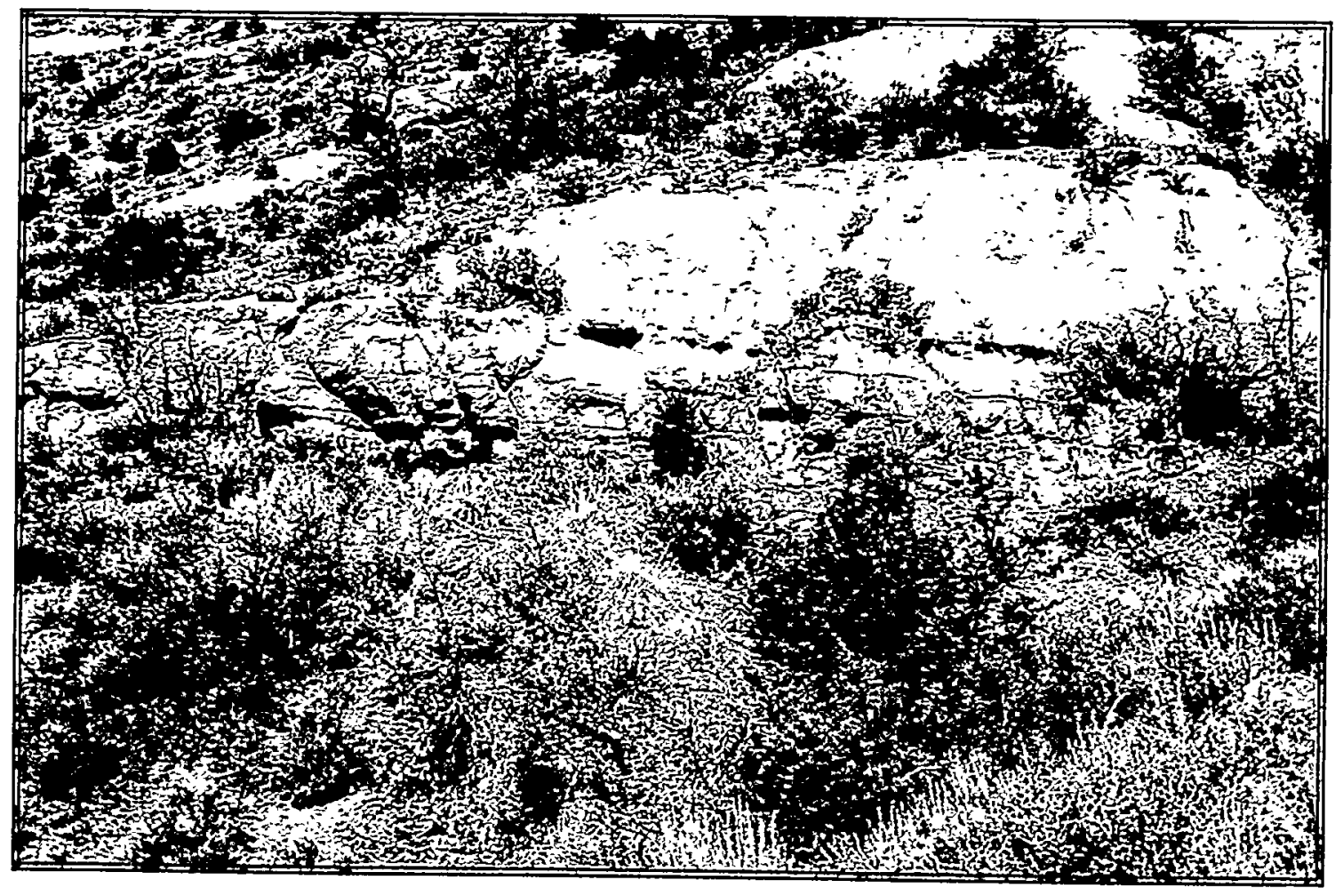

Photo 4-21 John's Spring below the rocky outcrop looking north on February 24, 1997 (JOHNS1.TIF)

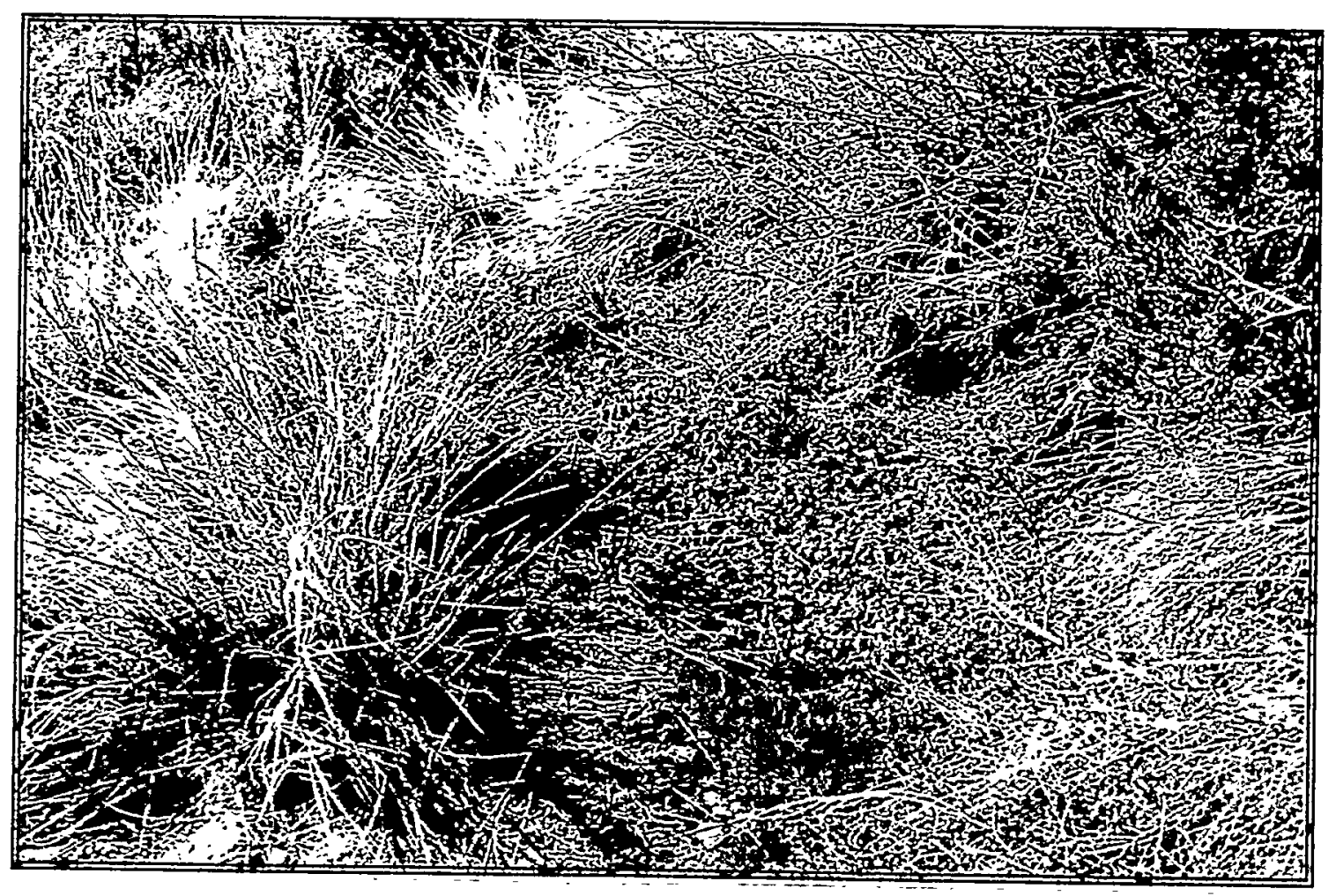

Photo 4-22 Wetland vegetation at John's Spring on February 24, 1997 (JOHNS2.TIF) 
wood embedded in the ground near the spring. It is likely that this spring was used by Native Americans because of its proximity to Oak Spring, where Native Americans had winter camps (Stoffle et al., 1990a). This spring appears to have been minimally impacted from mining activities in comparison to Oak Spring (see Section 4.2.9).

\subsubsection{Hydrophytic Vegetation}

A wetland vegetation survey was conducted at John's Spring in December 1996. From the observation point located at the ledge pool just below the rock face, 100 percent of the dominant plants were hydrophytic species, indicating that hydrophytic vegetation was present at this site (Table 4-9). Mosses and filamentous algae were common along the wet cliff face. Tufted evening primrose (Oenothera cespitosa var. marginata), although categorized as an "NL" species (see Methods, Section 3.2.4), was found primarily in seep areas of the rock face. Dominant hydrophytic species included clustered field sedge (Carex praegracilis) and seep monkeyflower which comprised about 80 percent of the cover of the ledge pool area. Other species such as stickywilly (Galium aparine) and an unidentified penstemon constituted plant species with less than 1 percent cover. An adjacent transitional area between the jurisdictional wetland and the upland was comprised of basin wildrye and smooth sumac. Within this transitional area, basin wildrye constituted about 60 percent cover and smooth sumac constituted about 20 percent cover. Species in the adjacent upland area included big sagebrush, fourwing saltbush, cheatgrass, mormon tea, singleleaf pinyon, desert bitterbrush (Purshia glandulosa), and Gambel's oak. The total area of the wetland habitat dominated by hydrophytic species was estimated to be about $50 \mathrm{~m}^{2}\left(538 \mathrm{ft}^{2}\right)$ (Table 5-1, Section 5.0) and was restricted to seep areas along the rock face and the ledge pool below the rock face.

\subsubsection{Wetland Hydrology and Water Quality}

Areas observed to have field indicators of wetland hydrology included seeps located in the rock face and a surface pool at the base of the rock face. Water seeps out of the rock face in numerous locations across a distance of about $25 \mathrm{~m}(82 \mathrm{ft})$ and flows down a steep slope for about $5 \mathrm{~m}(16 \mathrm{ft})$. Flow rate was measured at $0.4 \mathrm{\ell} / \mathrm{min}(0.01 \mathrm{gal} / \mathrm{min})$ in December 1996 (Table 5-1, Section 5.0). A 2-cm- (1-in)-deep surface pool exists on a relatively flat area at the base of the rock face. The surface area of this pool is about 5 $\mathrm{m}^{2}\left(54 \mathrm{ft}^{2}\right)$ and is covered with a dense growth of seep monkeyflower (Photo 4-22). Water quality measurements were not taken at this site.

\subsubsection{Hydric Soils}

Hydric soils at John's Spring were confined to the seep areas at the base of the rocky cliff and the ledge pool, and comprised about $50 \mathrm{~m}^{2}\left(538 \mathrm{ft}^{2}\right)$. Soils in these areas appeared to be saturated for at least seven days during the growing season, indicating the presence of hydric soil. 
have had winter camps at Oak Spring during the late 1800 s or early 1900 s (Stoffle et al., 1990a). Gold and silver mining activities occurred around 1905 in the Oak Spring area (Stoffle et al., 1990a). Historic disturbances at the site include depressions and excavation of soil from around the spring on the hillside, flattening of the slope just below the spring to provide space for small water drums, and old 5-cm- (2-in)-diameter metal pipes laid from the spring down the hillside. These disturbances suggest that Oak Spring was developed to provide water for these local mining activities. The metal pipe apparently provided water to living quarters and an old corral located about $1.6 \mathrm{~km}(1 \mathrm{mi})$ south of the spring (Giles, 1976). In the 1970s, DOE modified the site to enhance water availability to wildlife (Smith et al., 1978). An existing pipe, inserted in the ground below the spring, apparently directed water to two small converted 55-gallon (208- $\ell$ ) drum guzzlers (one with an animal-escape ladder). At the time of the survey on November 4, 1996, the mouth of the spring was a small opening or depression in the soil less than 0.5 $\mathrm{m}(2 \mathrm{ft})$ wide with observable flow, and both guzzlers were dry.

\subsubsection{Hydrophytic Vegetation}

Wetland vegetation around the saturated soils of the spring. was primarily a thick growth of small sandbar willow (Salix exigua) (Photo 4-24). Basin wildrye and smooth sumac also occurred in the adjacent moist soils. The willows comprised about a $40-\mathrm{m}^{2}\left(430-\mathrm{ft}^{2}\right)$ area around the spring outflow. Upland vegetation nearby was big sagebrush, fourwing saltbush, cheatgrass, green rabbitbrush, mormon tea, singleleaf pinyon, desert bitterbrush, and Gambel's Oak.

From the survey observation point, located at the spring pool, nearly 100 percent of the dominant plant species were wetland species (sandbar willow) indicating that hydrophytic vegetation was present (Table 4-10). Beatley (1976) reported five additional wetland plant species from Oak Spring (Table 5-3, Section 5.0) that were not detected during the survey: sturdy sedge (Carex alma), beardless wildrye (Leymus [Elymus] triticoides), seep monkeyflower, and beardless rabbitsfoot grass (Polypogon viridis). All of these species are obligate or facultative wetland species. It is probable that some of these species reestablish during periods of greater spring flow and moist soil conditions. Seeds of some of these plants might readily disperse to the site from plants growing at John's Spring about $250 \mathrm{~m}(820 \mathrm{ft})$ away. 


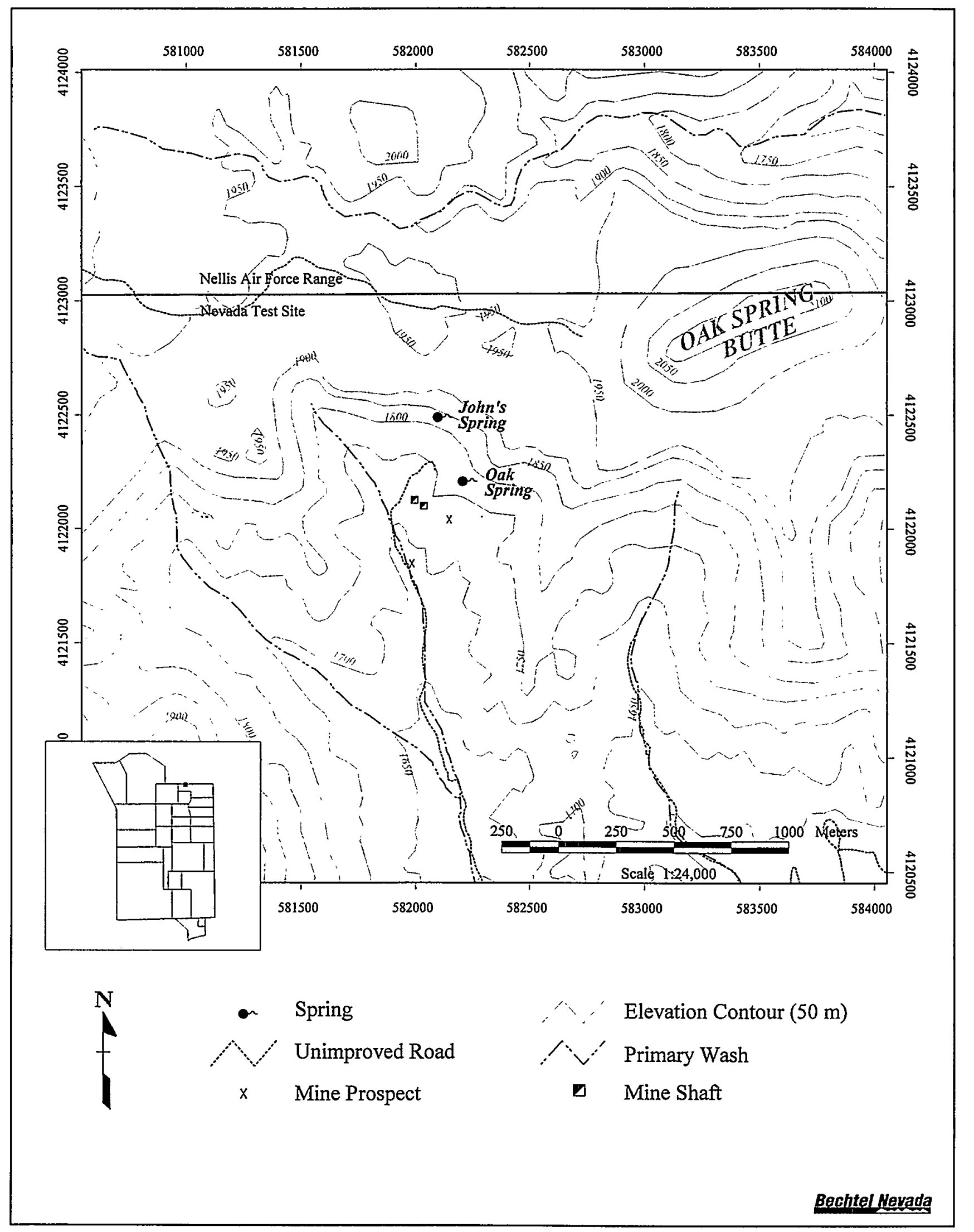

Figure 4-9 Location of Oak Spring 


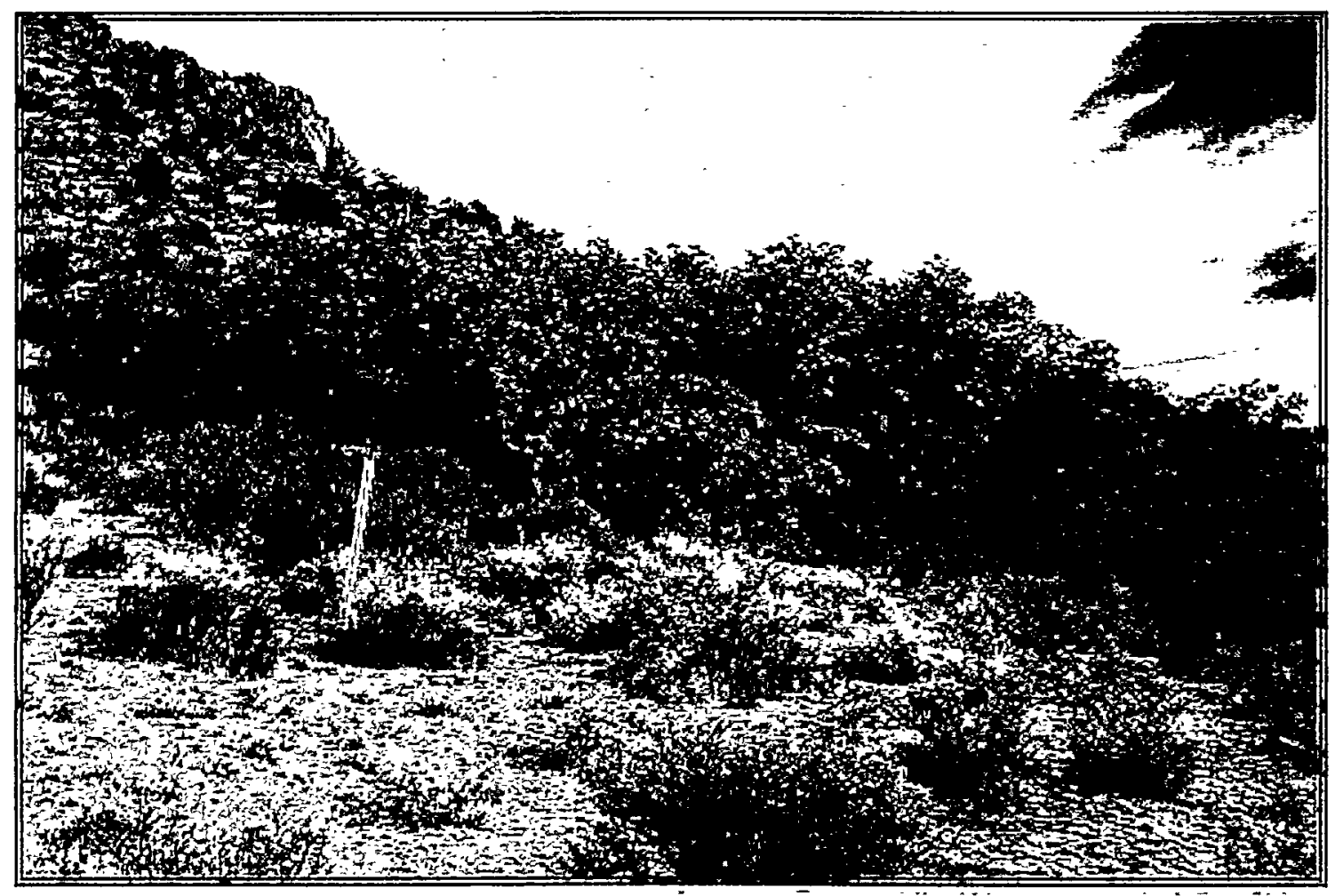

Photo 4-23 Vegetation at Oak Spring looking south on November 4, 1996 (WS343-13.TIF)

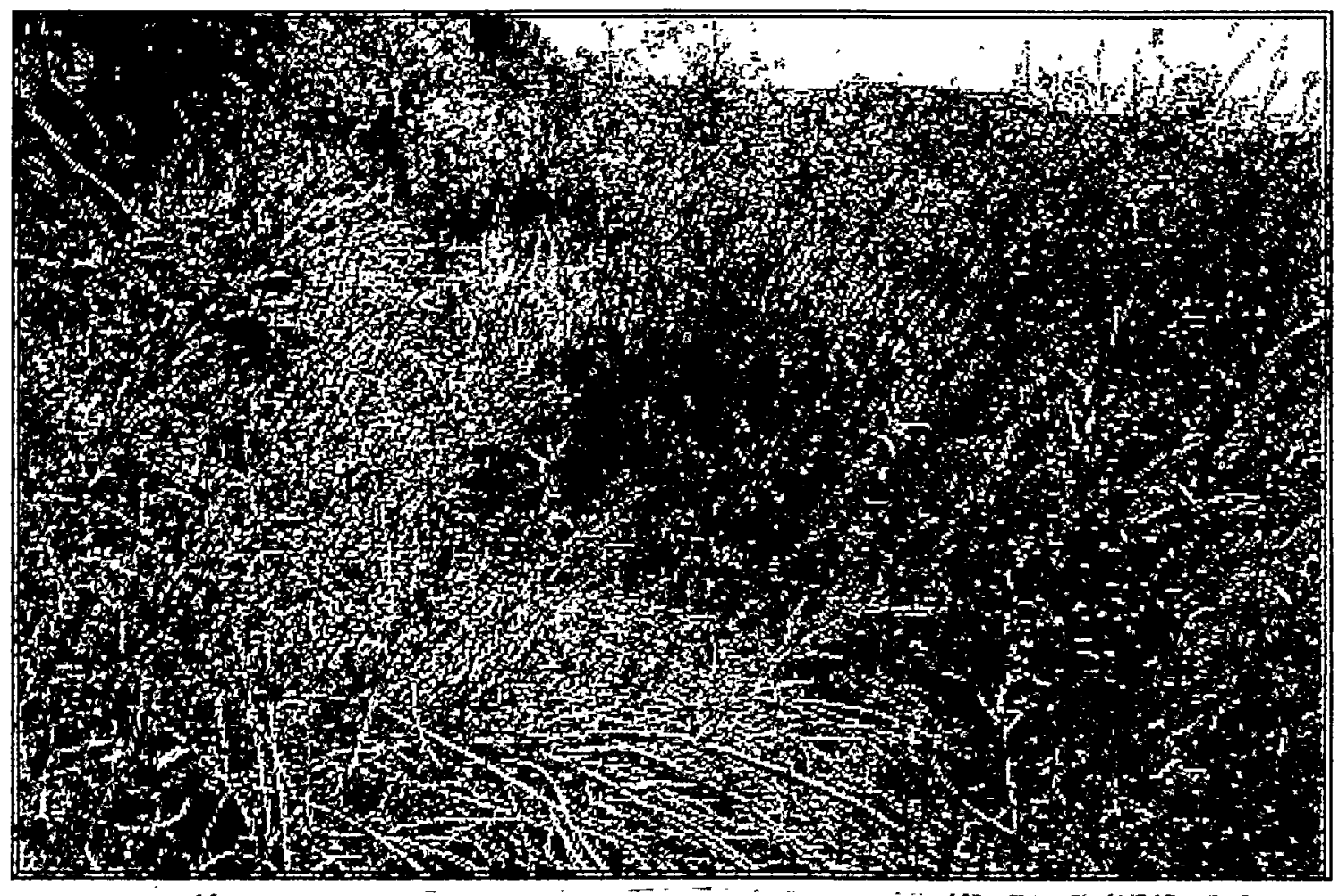

Photo 4-24 Closeup of wetland vegetation at Oak Spring on November 4, 1996 (WS343-16.TnF) 


\section{Habitat: Spring Outflow}

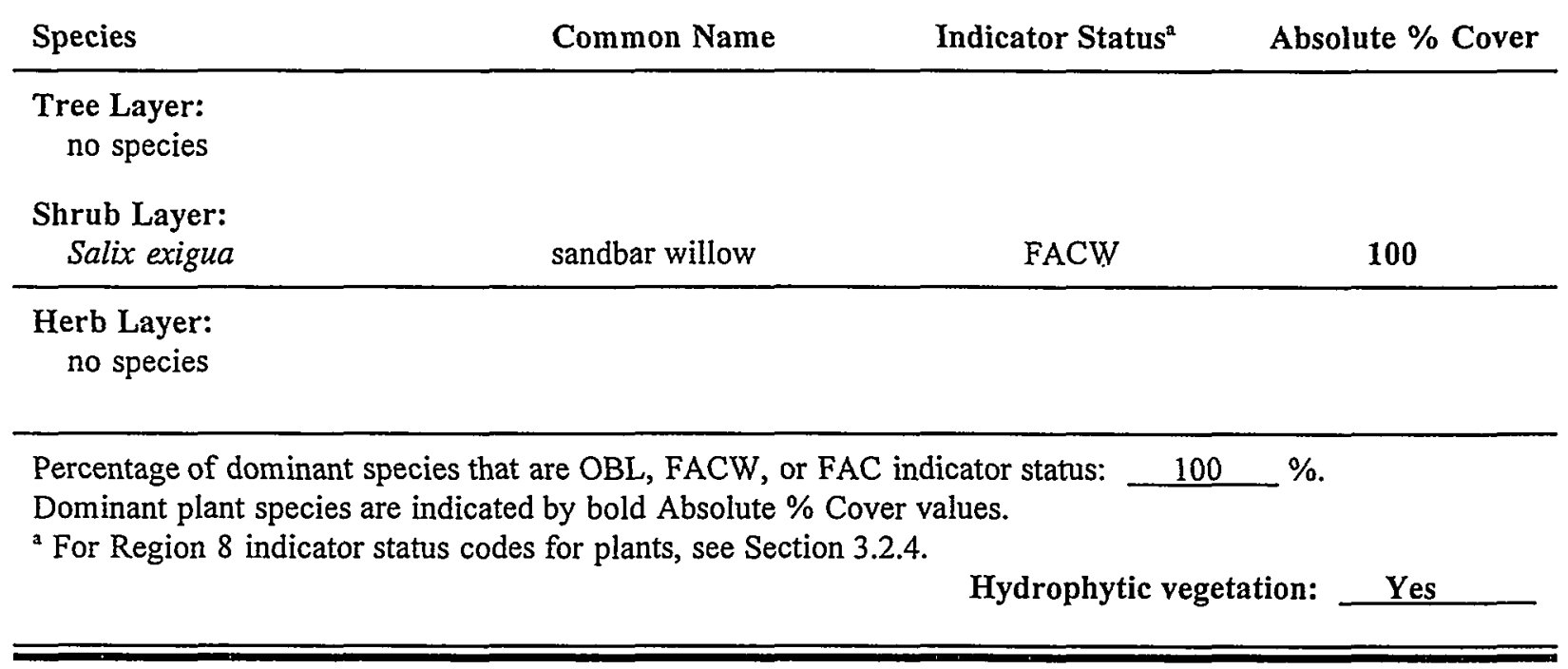

An adjacent transitional area between the jurisdictional wetland and upland areas was comprised of basin wildrye and smooth sumac. Within this transitional area, basin wildrye constituted about 30 percent cover and smooth sumac about 5 percent.

\subsubsection{Wetland Hydrology and Water Quality}

Field indicators of wetland hydrology were restricted to one area during the wetland survey in November 1996. This area was a small pool of surface water less than $1 \mathrm{~m}^{2}$ (11 $\left.\mathrm{ft}^{2}\right)$ in area and about $2.5 \mathrm{~cm}(1 \mathrm{in})$ deep. Flow out of this pool was measured at 0.4 $\ell / \mathrm{min}(0.1 \mathrm{gal} / \mathrm{min}$ ) in December 1996 (Table 5-1, Section 5.0). No water quality measurements were taken at the site.

\subsubsection{Hydric Soils}

Field indicators for hydric soils were restricted to saturated soils at the surface pool at Oak Spring. Soils were fairly shallow and limited in areal extent. Soil mottling was not observed in the soil pit that was dug; however, soils had a moderate amount of dark organic matter and were saturated for what appeared to have been greater than seven days during the growing season, indicating the presence of hydric soils. The spring had apparently been excavated and soils may have represented an atypical situation.

\subsubsection{Determination of Jurisdictional Status}

Only the small area at Oak Spring occupied by sandbar willow met the criteria to be considered as a jurisdictional wetland because it had field indicators for all three required 
parameters: hydrophytic vegetation, wetland hydrology, and hydric-soils. Other areas lacked field indicators for hydrophytic vegetation.

\subsubsection{Wildlife Use}

Few observations of wildlife have been made at this site due to its remote location. Mule deer are common in the area as evidenced by the presence of scat near the spring. Other species which have been observed in the past include black-tailed jackrabbits, mourning doves, common ravens, and scrub jays (Aphelocoma coerulescens). The grove of Gambel's oak probably offers significant cover for many species of wildlife.

\subsubsection{Pavits Spring}

\subsubsection{Site Description and Historical Use}

Pavits Spring is located in a remote area east of Hampel Hill in a wash bottom about 3.2 km (2 mi) southwest of Frenchman Flat (Figure 4-10; Photos 4-25 and Photo 4-26). There is no evidence that indicates this spring has been modified by man. Surface water was observed in a small pool about $20 \mathrm{~cm}$ (8 in) deep at Pavits Spring during previous visits to this spring on February.2, March 23, and September 9, 1988 (Photo 4-27). However, during the September 1996 visit, the spring pool was dry (Photo 4-28).

\subsubsection{Hydrophytic Vegetation}

The only wetland plant species recorded at Pavits Spring during September 1996 was alkali sacaton (Sporobolus airoides). This species was confined to an area less than $1 \mathrm{~m}^{2}$ $\left(11 \mathrm{ft}^{2}\right.$ ). Upland species in the area include creosotebush (Larrea tridentata), white burrowbush (Ambrosia dumosa), rubber rabbitbrush, orchardgrass (Dactylus glomerata), blugrasses, and largeflower suncup (Cane Spring evening primrose).

From the survey observation point located at the dry wash pool, only 33 percent of the dominant plant species were wetland species (Table 4-11), indicating that field indicators for hydrophytic vegetation were not present at Pavits Spring.

\subsubsection{Wetland Hydrology And Water Quality}

Field indicators for wetland hydrology consisted of water marks on the sides of the dry spring pool. Surface water did not exist at Pavits Spring during the wetland survey in September 1996 (Photo 4-28). The spring pool (dry during the September 1996 survey) is located at the bottom of a hill and adjacent to a drainage channel. No water quality measurements were taken at this site.

\subsubsection{Hydric Soils}

Field indicators for hydric soils were not observed at this site. Soil pits were not dug because of the potential to disturb the small pool site. Soils at this site are poorly developed, with little organic matter. 


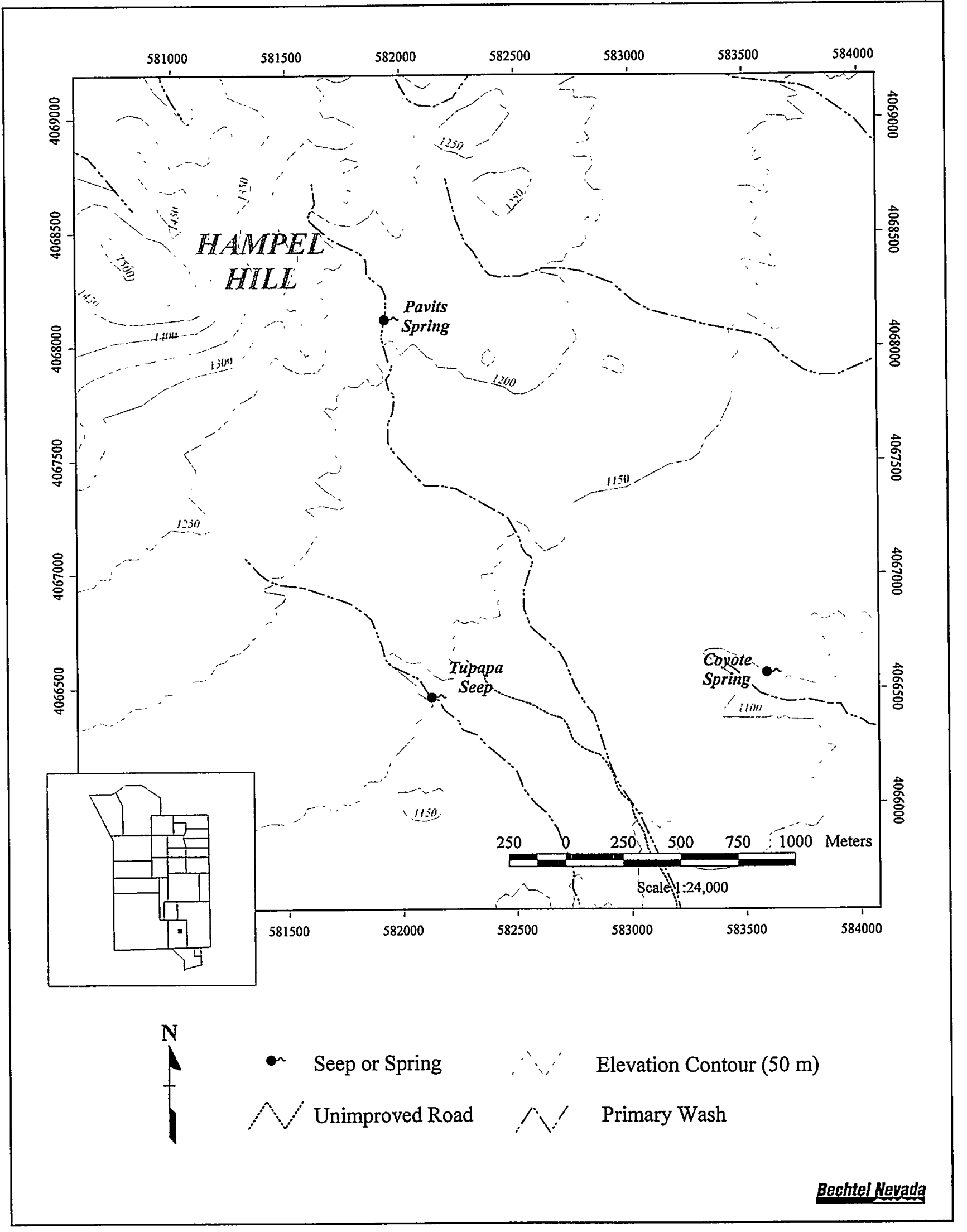

Figure 4-10 Location of Pavits Spring 


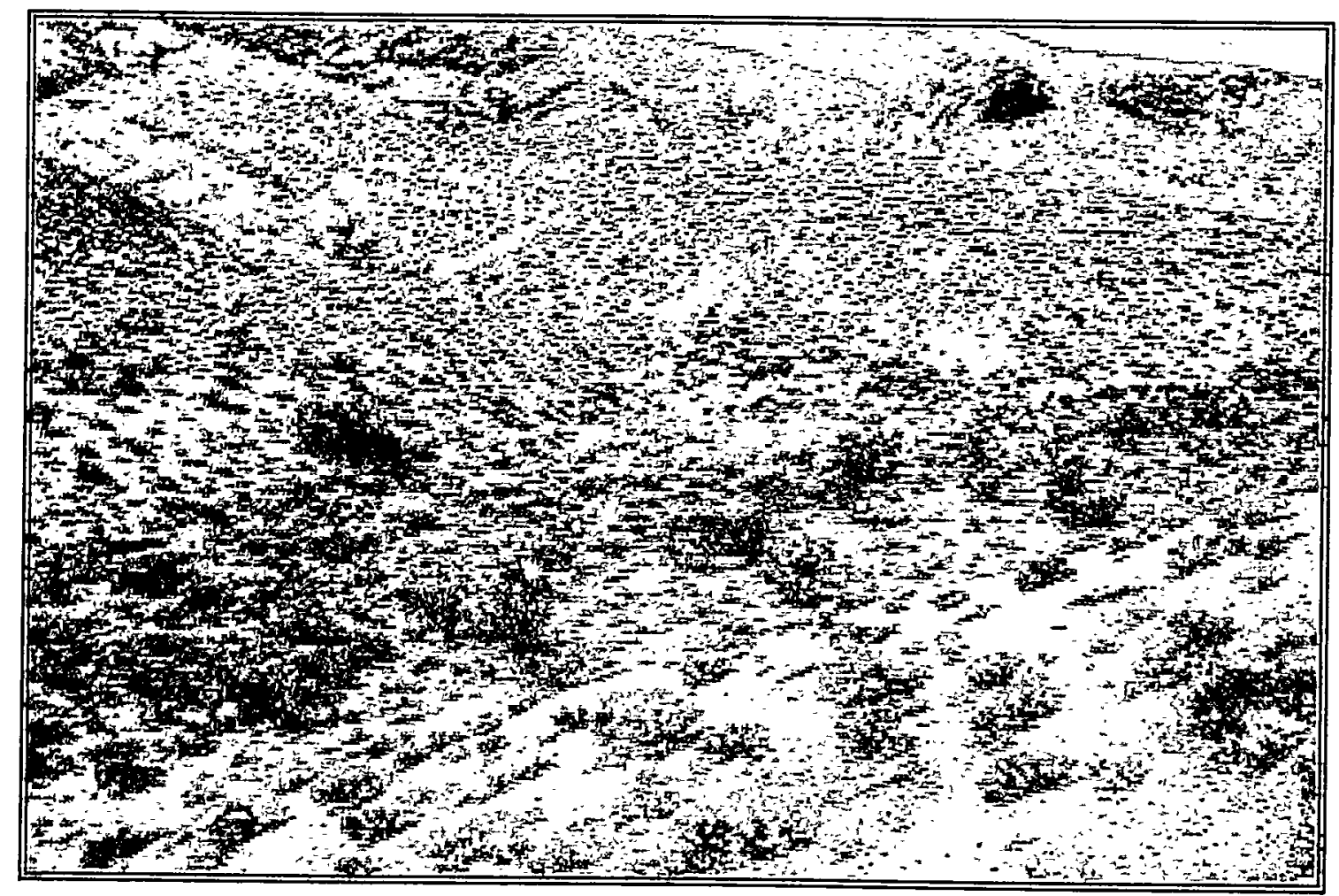

Photo 4-25 Habitat of Pavits Spring looking north on September 9, 1988 (WS036-17.TIF)

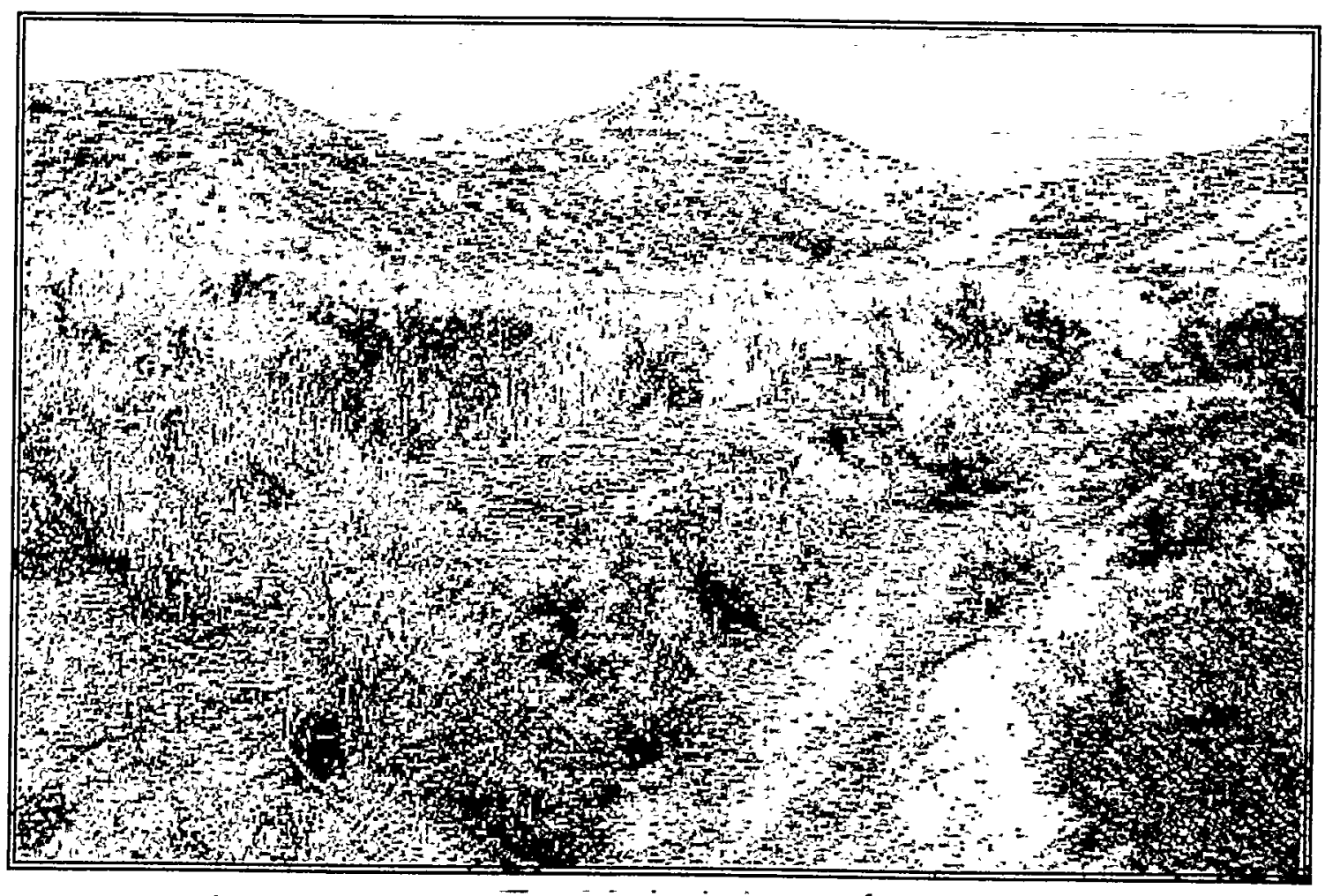

Photo 4-26 Wash vegetation around Pavits Spring looking northeast on September 9, 1988 (WS036-14.TIF) 


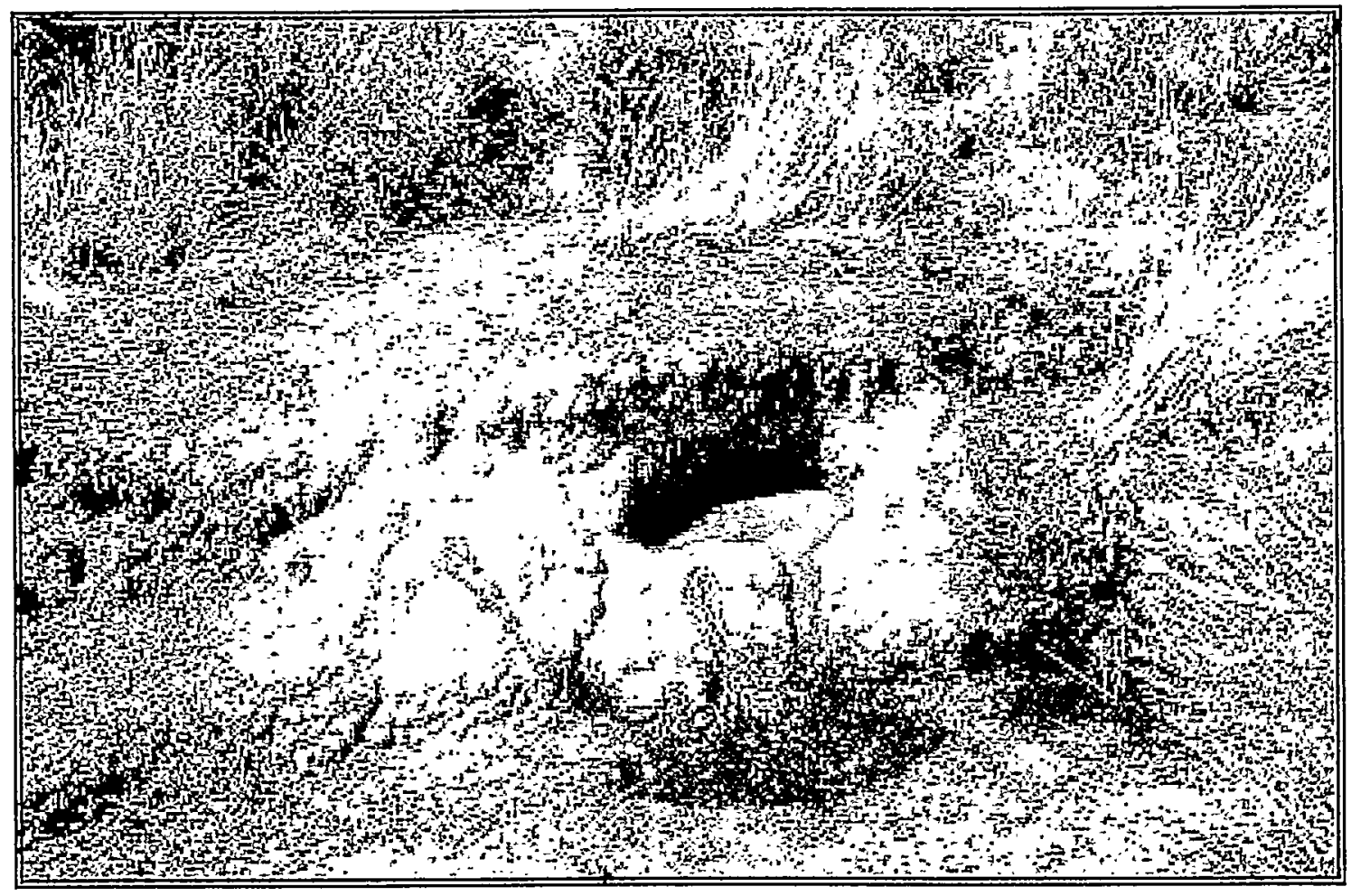

Photo 4-27 Pavits Spring pool with water on September 9, 1988 (WS036-10.TIF)

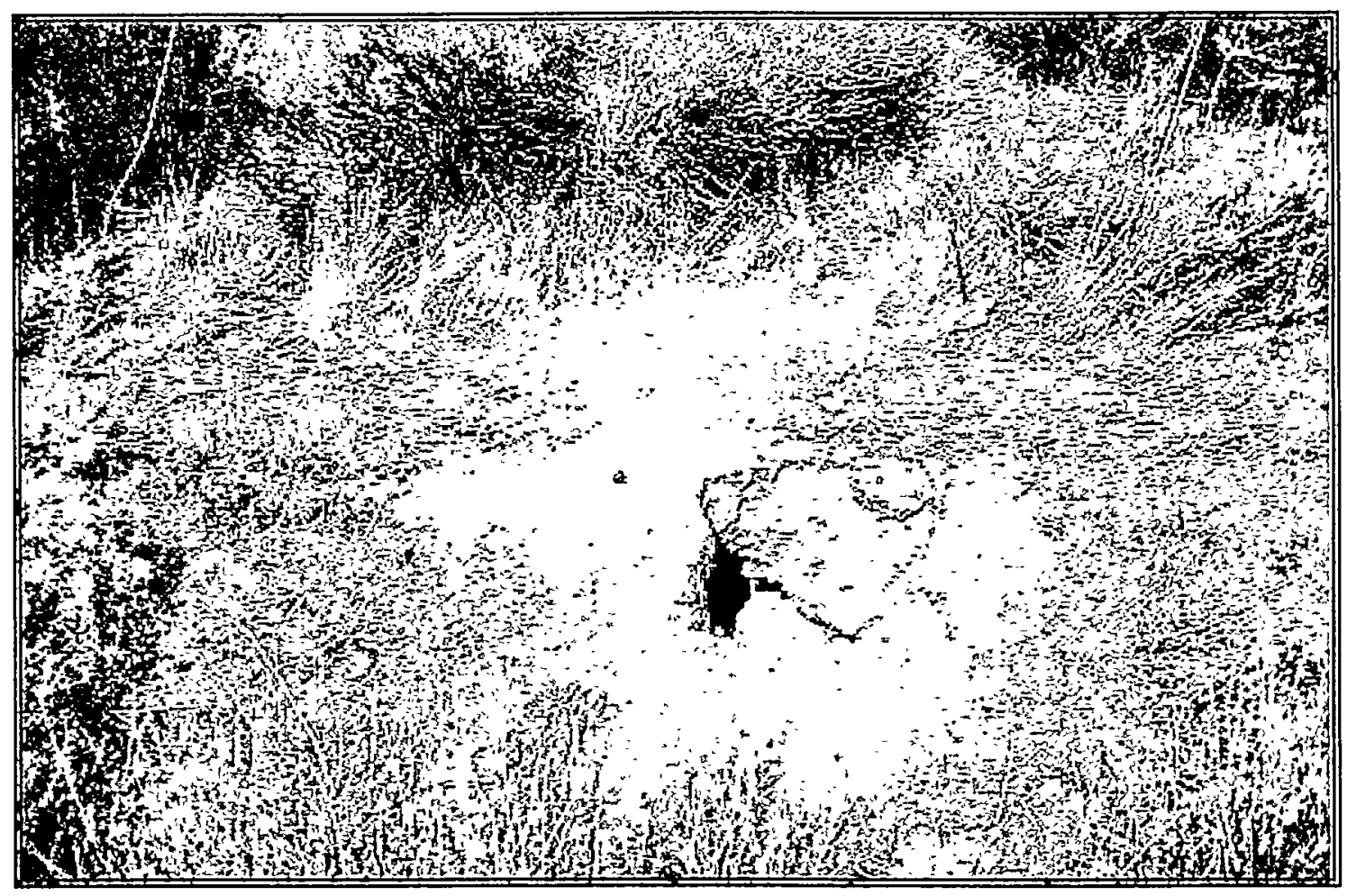

Photo 4-28 Dry pool at Pavits Spring on September 4, 1996 (WS502-01.TIF) 
Table 4-11 Pavits Spring wetland vegetation as surveyed on September 4, 1996

\section{Habitat: Dry Wash Pool}

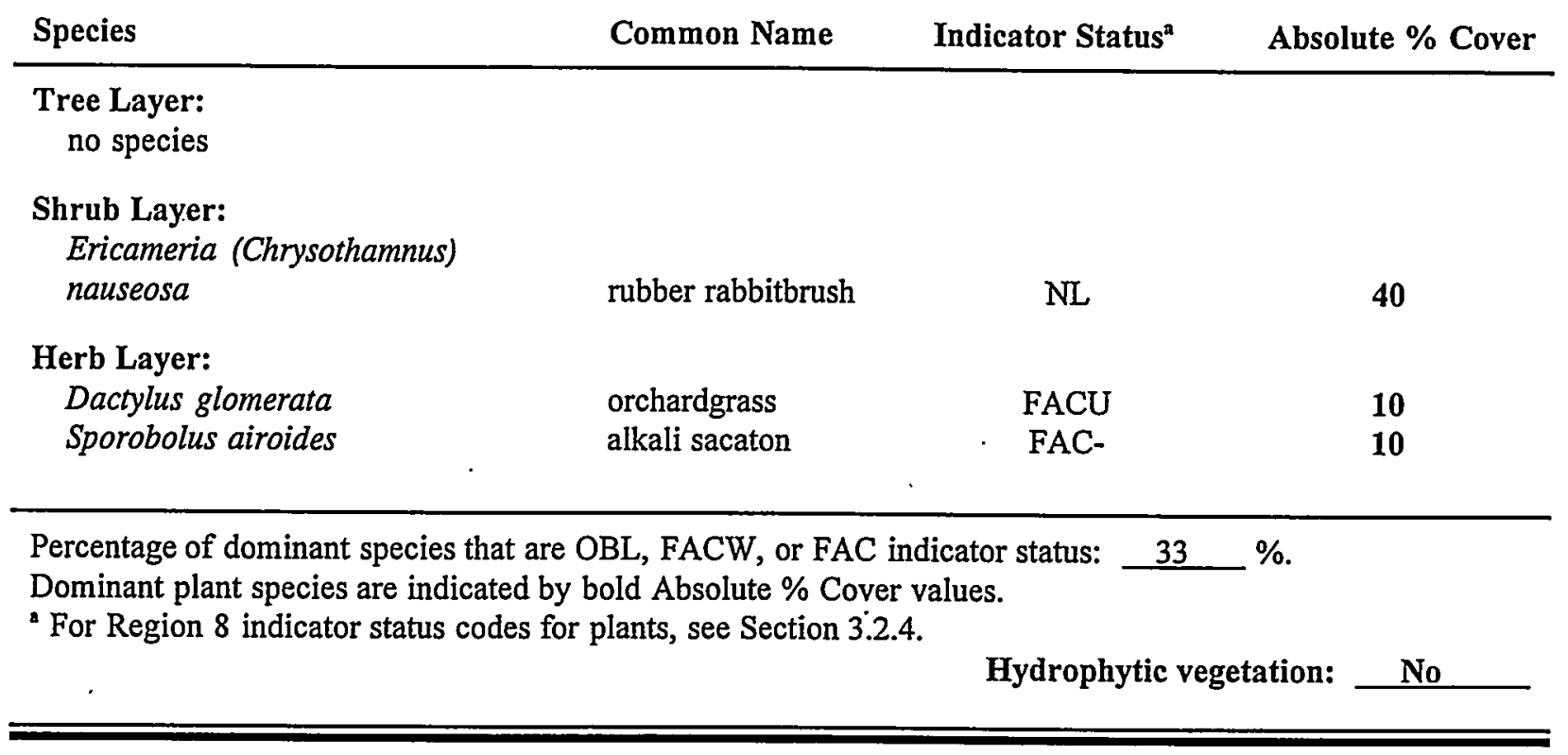

\subsubsection{Determination of Jurisdictional Status}

Because of the lack of hydrophytic vegetation and hydric soils, it is probable that Pavits Spring would not be considered a jurisdictional wetland.

\subsubsection{Wildlife Use}

Wildlife which use Pavits Spring include desert cottontails (Sylvilagus audobonii), coyotes, Gambel's quail, hummingbirds, and mule deer. Invertebrate groups recorded from water samples from Pavits Spring in 1988 (Greger, unpublished notes) include chironomids (aquatic midges), cladocerans (water fleas), oligochaetes (aquatic earthworms), and nematodes (round worms).

\subsubsection{Rainier Spring}

\subsubsection{Site Description and Historical Use}

Rainier Spring is located in a wash adjacent to a dirt road approximately $300 \mathrm{~m}(984 \mathrm{ft})$ north of E Tunnel Portal (Figure 4-11, Photo 4-29). This site was apparently used in the 


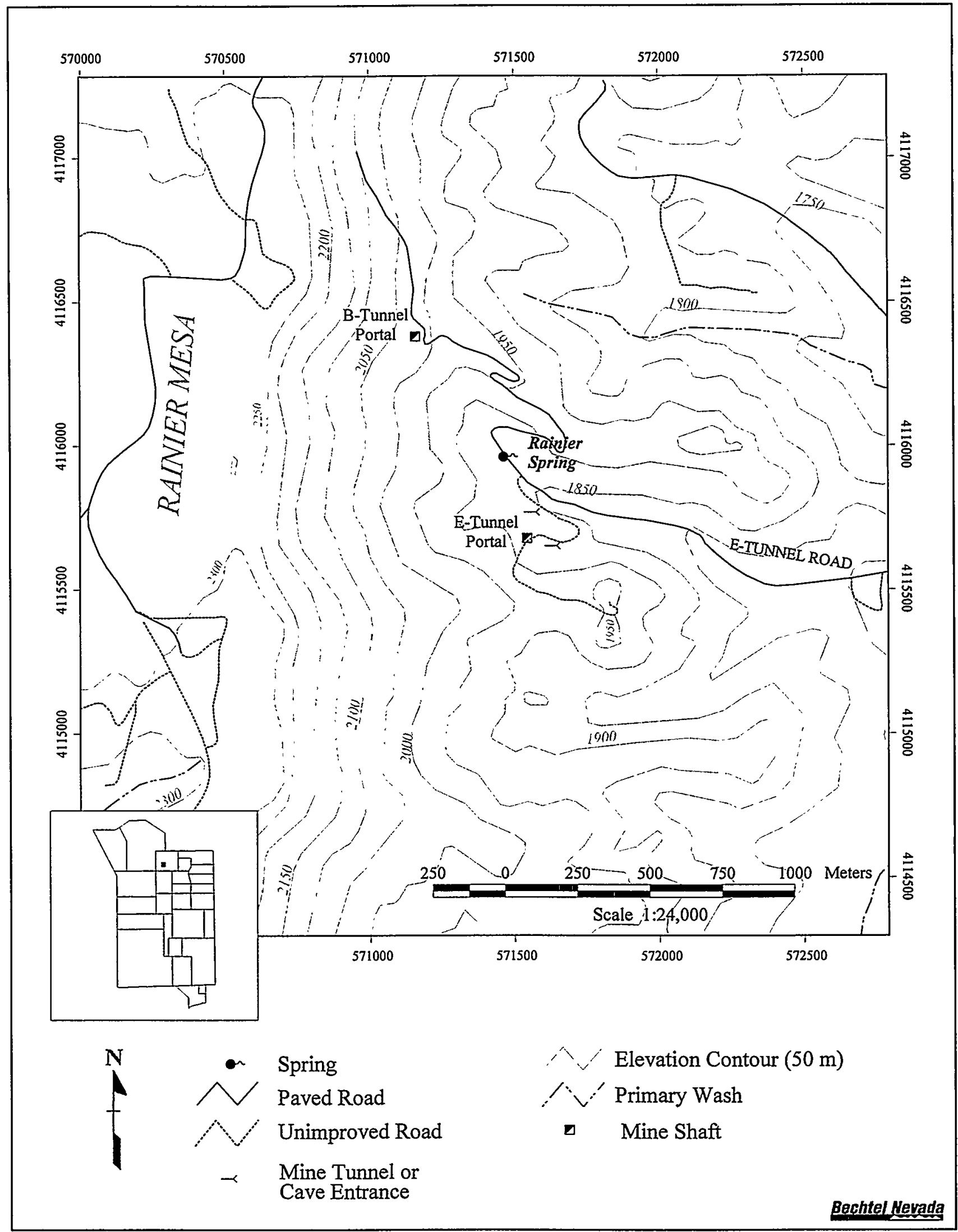

Figure 4-11 Location of Rainier Spring 


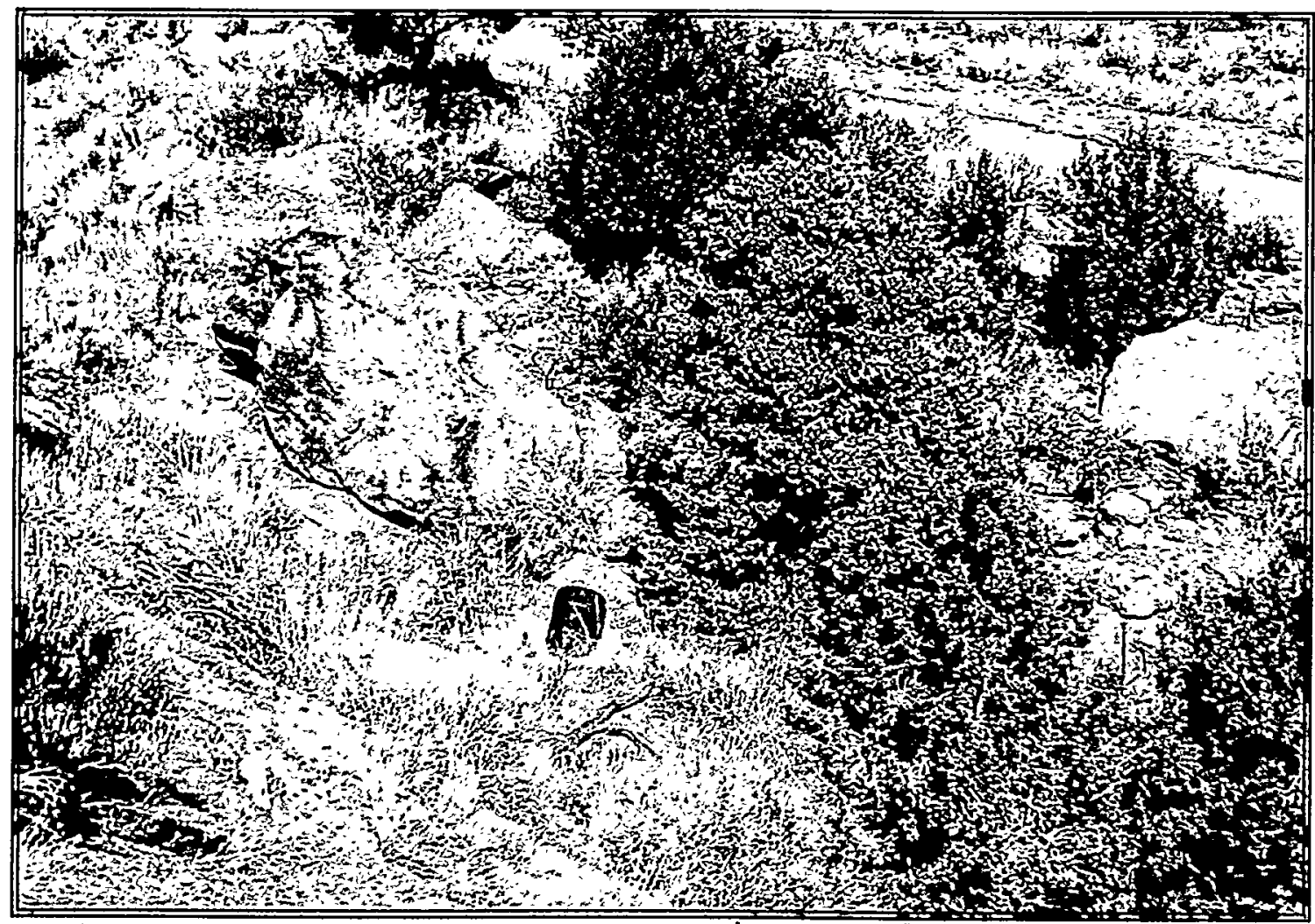

Photo 4-29 Habitat at Rainier Spring looking north on February 20, 1997 (RAINIER1.TIF)

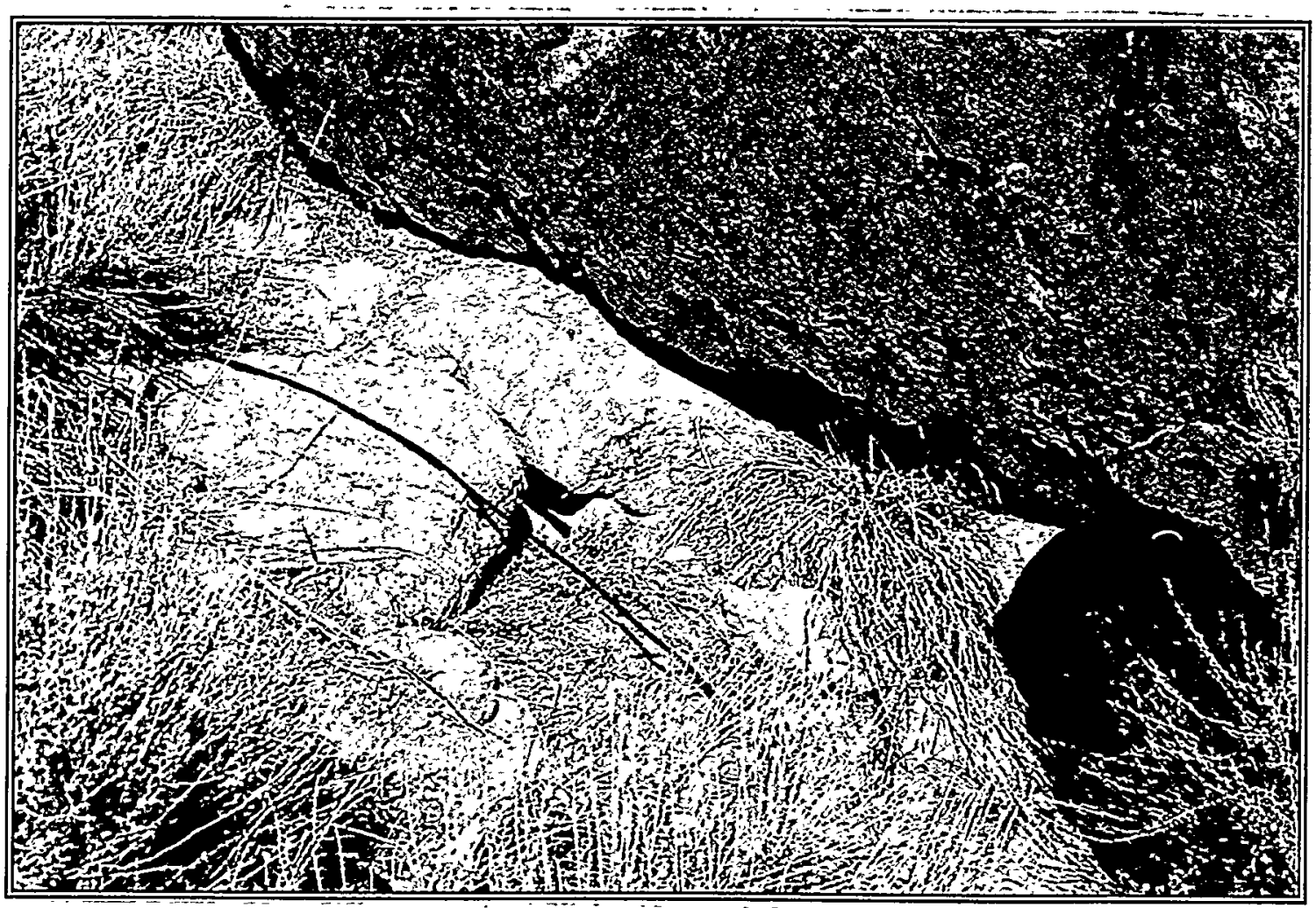

Photo 4-30 Closeup of vegetation at Rainier Spring on February 20, 1997 (RAINIER2.TIF) 
1900s to water livestock, as evidenced by the presence of metal water tanks. Several metal pipes exist in the wash. One outflow pipe was inserted into the rocks about $10 \mathrm{~m}$ (33 ft) above several water guzzlers which were made from 55-gallon (208- $\ell$ ) drums and were filled partially with sediment (Photo 4-30). A wooden post was inserted into the wash sediment apparently to secure or stabilize one of the tanks. An overturned stock tank about $1.8 \mathrm{~m}(6 \mathrm{ft})$ long $\times 0.6 \mathrm{~m}(2 \mathrm{ft})$ wide was located about $10 \mathrm{~m}(33 \mathrm{ft})$ further down the wash from the drums.

\subsubsection{Hydrophytic Vegetation}

The wetlands survey performed on December 18, 1996, showed that basin wildrye, a nonhydrophytic plant, was the only dominant plant species present in the wash at Rainier Spring and comprised about 30 percent of the cover in the wash (Table 4-12). The area of the wash where basin wildrye occurred was about $22 \mathrm{~m}^{2}\left(237 \mathrm{ft}^{2}\right)$. Plant species in the surrounding upland included big sagebrush, mormon tea, rubber rabbitbrush, Utah juniper, and singleleaf pinyon. It was concluded that hydrophytic vegetation did not occur at this site at the time of the survey, although basin wildrye is indicative of mesic areas elsewhere on the NTS.

Table 4-12 Rainier Spring wetland vegetation as surveyed on December 18, 1996

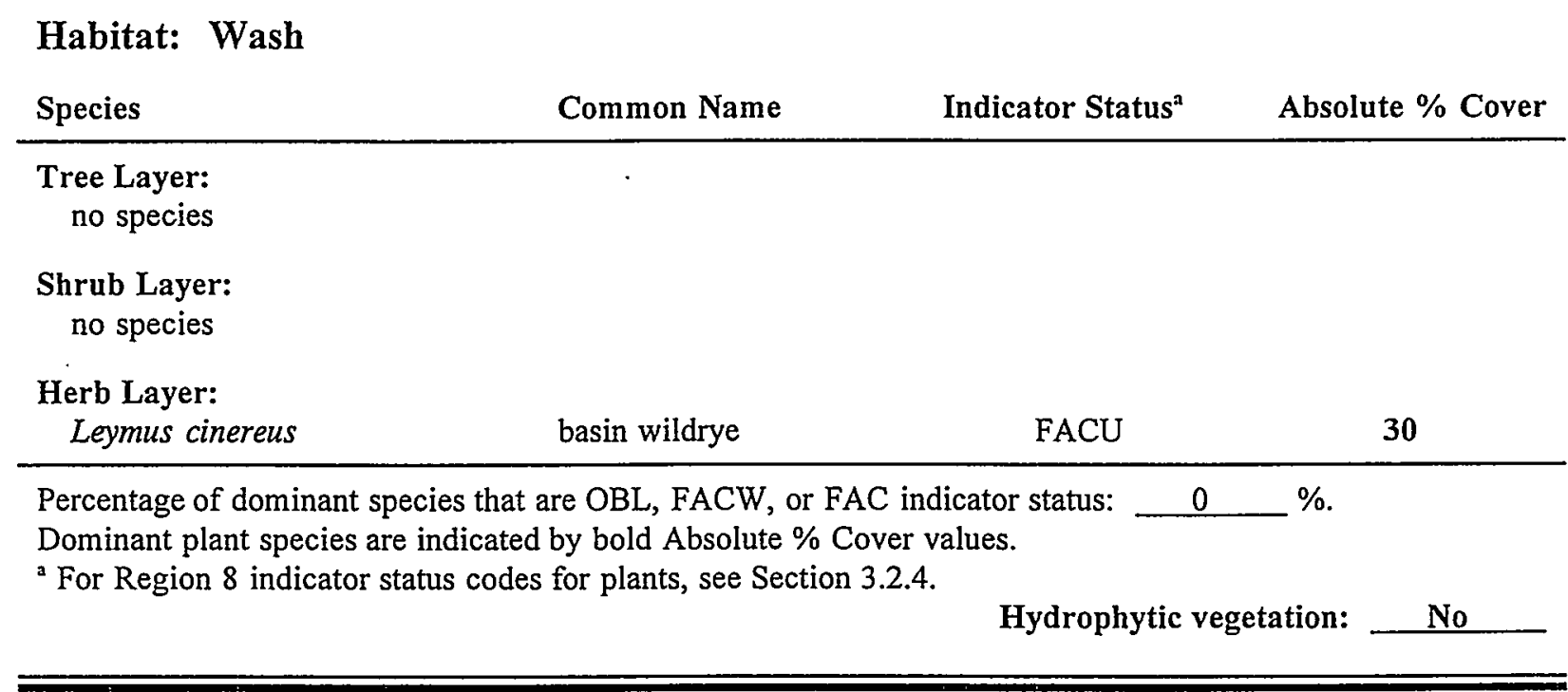

\subsubsection{Hydrology}

Rainier Spring was reported to have water on September 18, October 4, and October 15, 1957 (Moore, 1961). This site was sampled for water quality and radioactivity at that time. Rainier Spring was reported to be dry on November 10, 1960 (Moore, 1961). No flow was observed from the outflow pipe in 1996. A dirt road leading to B Tunnel exists within $20 \mathrm{~m}(66 \mathrm{ft})$ of the spring site. The construction of this road may have influenced 
drainage and recharge patterns of the area by intercepting rainfall and directing water flow down the road. This could have decreased spring discharge. Surface water was absent at Rainier Spring on December 18, 1996, and no water quality measurements were taken.

\subsubsection{Hydric Soils}

No field indicators of hydric soils (such as surface water or saturated soils) were observed at Rainier Spring.

\subsubsection{Jurisdictional Wetland Determination}

Rainier Spring would probably not be considered a jurisdictional wetland because it lacked all three characteristics of a jurisdictional wetland: hydrophytic vegetation, wetland hydrology, and hydric soils.

\subsubsection{Wildlife Use}

The Rainier Spring site has little value for wildlife use because it lacks surface hydrology. No wildlife or their sign were observed at the site during the wetland survey.

\subsubsection{Reitmann Seep}

\subsubsection{Site Description and Historical Use}

Reitmann Seep was also known as Green Spring (Giles, 1976); however, this site is unnamed (i.e., referred to as "spring") on the Paiute Ridge USGS 7.5-Minute Series quadrangle map (1986). The name "Reitmann Seep" has been commonly used in past DOE reports. It is about $3 \mathrm{~km}(2 \mathrm{mi})$ east of Yucca Flat and southwest of Slanted Buttes (Figure 4-12, Photo 4-31). The seep forms a very small pool (Photo 4-32) and contains about $23 \ell$ (6 gal) of water throughout the year (Giles, 1976). The pool and surrounding vegetation have an area of about $1 \mathrm{~m}^{2}\left(11 \mathrm{ft}^{2}\right)$. The slope above Reitmann Seep is moderately steep and heavy rainfall commonly fills the pool with sediment. Little information on historical use of Reitmann Seep by humans is known. The seep was improved by man during recent times, apparently for the purpose of supplying water to wildlife. A 55-gallon (208- $\ell$ ) drum (now heavily rusted) is cut open on one side and

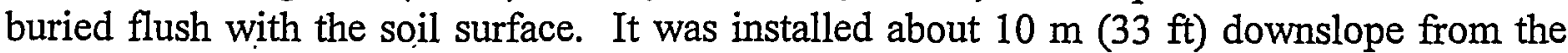
spring pool and is fed water through a pipe. The pipe from the pool to the drum is buried in a narrowly excavated channel.

\subsubsection{Hydrophytic Vegetation}

Wetlands vegetation at Reitmann Seep includes Parish's spikerush (Eleocharis parishii) and annual rabbitsfoot grass. From the survey observation point at the spring pool, about 66 percent of the dominant plant species around the seep were wetland species (Table 4-13), indicating that hydrophytic vegetation was present at Reitmann Seep. This area of 


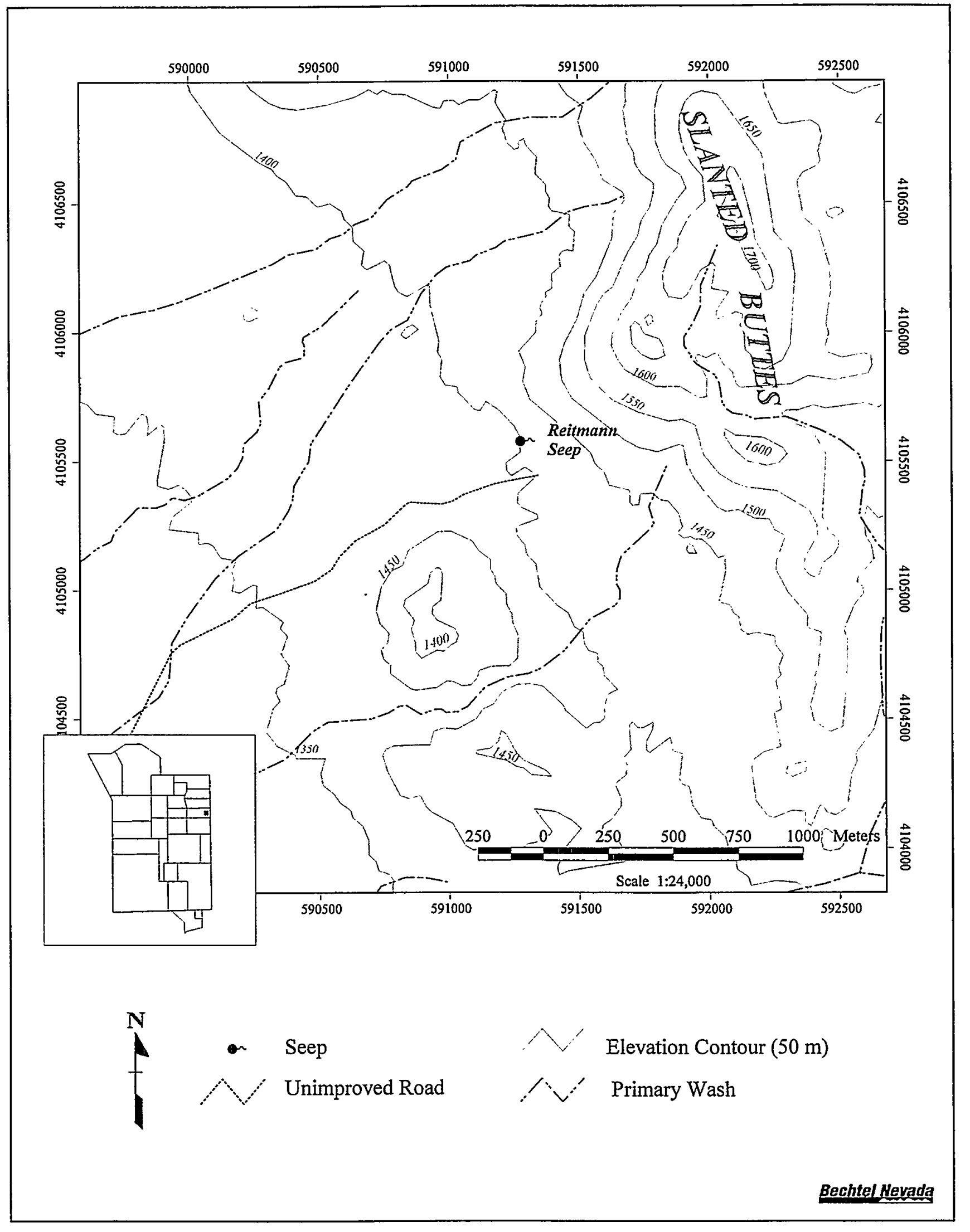

Figure 4-12 Location of Reitmann Seep 


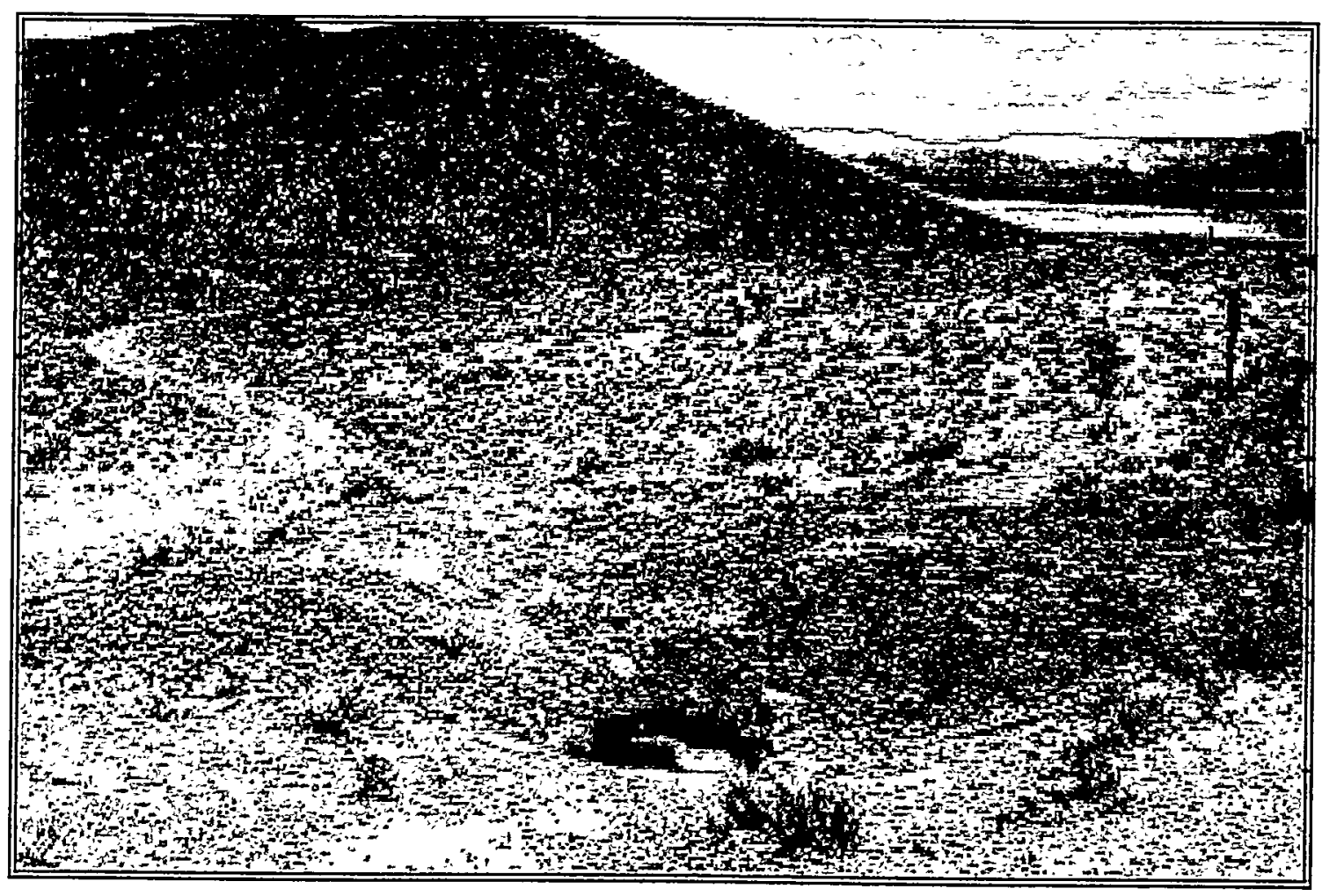

Photo 4-31 Habitat of Reitmann Seep looking southwest on June 2, 1989 (WS110-22.TIF)

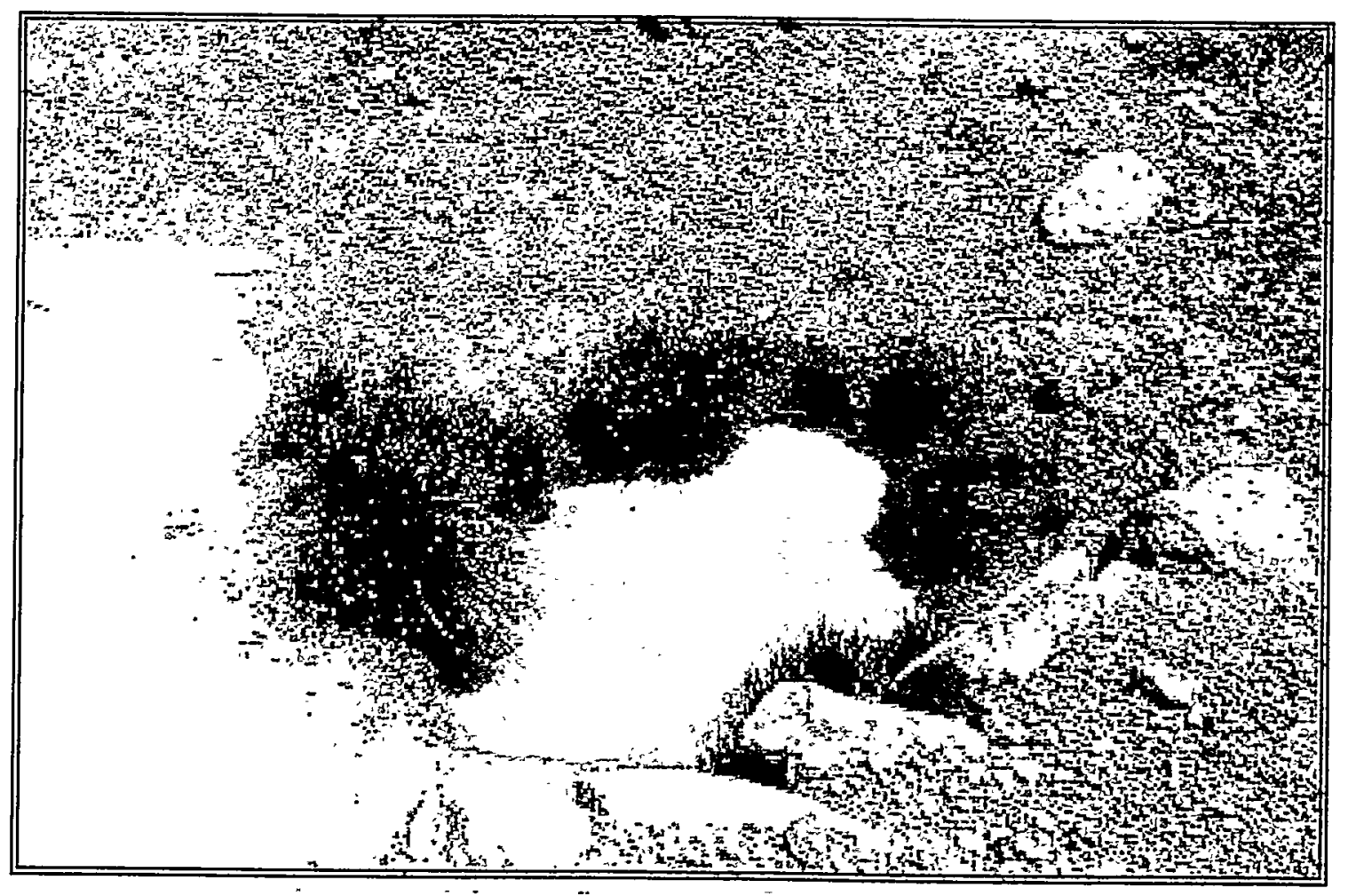

Photo 4-32 Pool at Reitmann Seep on June 2, 1989 (WS110-23.TIF) 


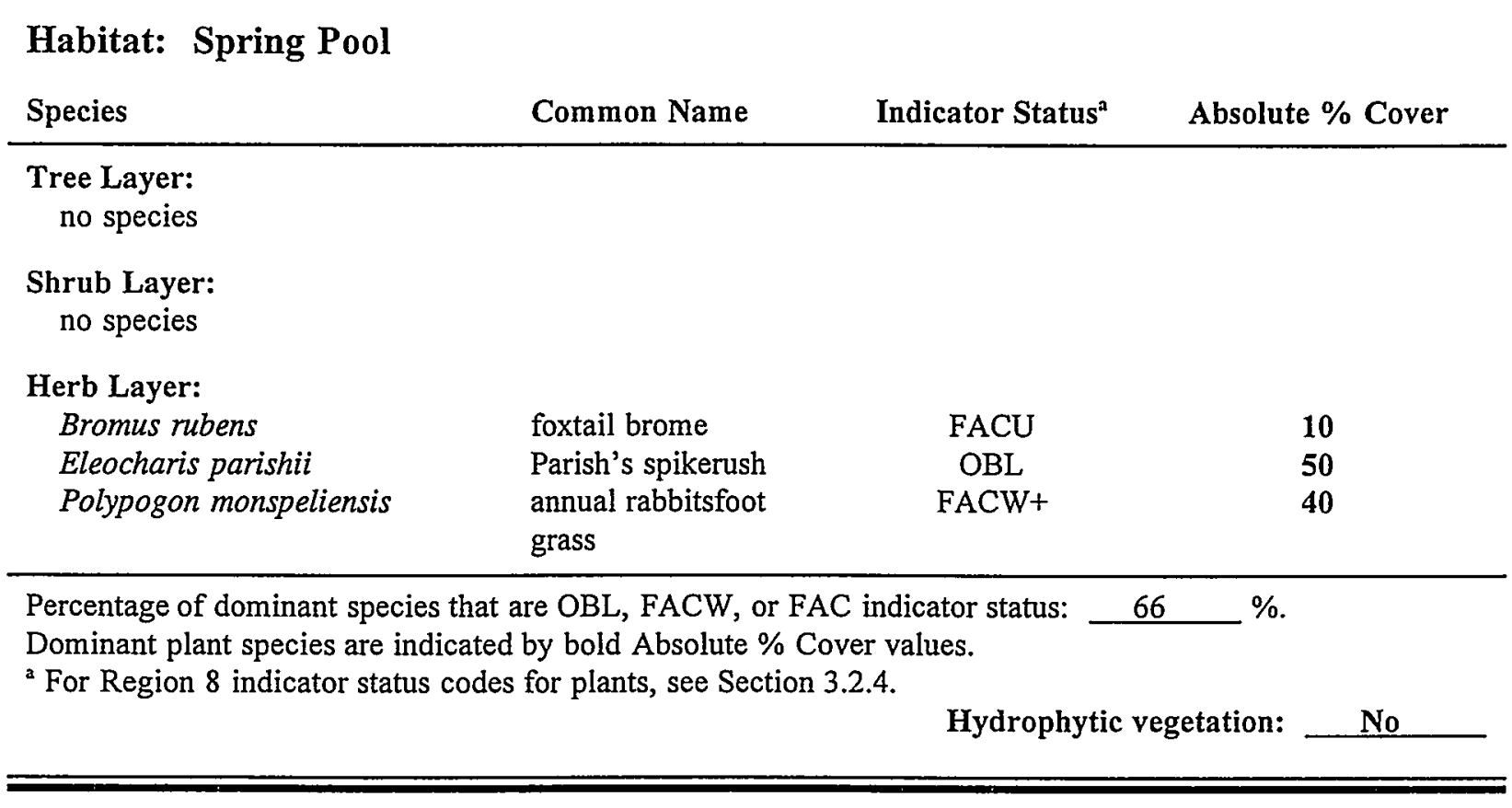

wetland vegetation is very small (about $1 \mathrm{~m}^{2}\left[11 \mathrm{ft}^{2}\right]$ ). Vegetation of the upland plant community adjacent to the wetland included fourwing saltbush, foxtail brome, blackbrush, and Joshua tree (Yucca brevifolia).

\subsubsection{Wetland Hydrology and Water Quality}

Surface water is present throughout the year at Reitmann Seep in a small pool and a guzzler whose combined area is approximately $1.5 \mathrm{~m}^{2}\left(12 \mathrm{ft}^{2}\right)$. The pool is located at the base of a fractured, rocky hillside in an earthen basin that appears to have been formed by runoff water from the hillside above the pool. Flow rates measured from an existing pipe inserted into the ground at the spring were low and varied from $0.03 \mathrm{l} / \mathrm{min}(0.007$ $\mathrm{gal} / \mathrm{min}$ ) in September 1996 to $0.2 \mathrm{\ell} / \mathrm{min}(0.05 \mathrm{gal} / \mathrm{min}$ ) in November 1996 (Table 5-1, Section 5.0). Water quality measurements were taken in June, July, September, and November 1996. Data are presented in Table 5-2 (Section 5.0).

\subsubsection{Hydric Soils}

Hydric soils were restricted to the saturated soils at the spring pool at Reitmann Seep. These soils appear to be saturated for more than seven days during the plant growing season, indicating the presence of hydric soil. Soils are very black and appear high in decaying organic matter, most of which appears to be plant litter that has blown into the pool from adjacent upland vegetation. 


\subsubsection{Determination of Jurisdictional Status}

The spring pool at Reitmann Seep, although very small in size, meets the criteria to be considered a jurisdictional wetland based on the presence of all three required parameters: wetland hydrology, hydrophytic vegetation, and hydric soils.

\subsubsection{Wildlife Use}

Wildlife commonly using Reitmann Seep include coyotes, mule deer, mourning doves, Gambel's quail, and passerine birds such as sage sparrows (Amphispiza belli). Invertebrates observed at the site include ostracods.

\subsubsection{Rock Valley Tank}

\subsubsection{Site Description and Historical Use}

Rock Valley Tank is located at the western edge of Rock Valley near the base of a limestone ridge (Figure 4-13, Photo 4-33). Little is known about human use of this water tank. It is likely that Native Americans used the site because Native American artifacts occur within $3 \mathrm{~km}$ (1.9 mi of the water source near the southwest base of Skull Mountain (Colleen Beck [DRI], personal communication, 1992). Little evidence of human disturbance was observed at this site. Near the water source, some rocks had been moved and stacked into a pile.

\subsubsection{Hydrophytic Vegetation}

- Hydrophytic vegetation was absent from the Rock Valley Tank site. Foxtail brome was the dominant plant growing in dark soils near the tank (Table 4-14). This mesic area below the tank covered about $25 \mathrm{~m}^{2}\left(269 \mathrm{ft}^{2}\right)$ surface area. Plant species in the surrounding upland area included white burrobush, Nevada jointfir, and creosotebush.

\subsubsection{Hydrology}

Surface water was present at the Rock Valley Tank on January 7, 1997, and was observed in the small rock opening measuring about $20 \times 30 \mathrm{~cm}(8 \times 12$ in) at the base of a limestone ridge (Photo 4-34). No water flow from the rock cavity was observed. The depth of water inside the rock cavity near the surface was about $30 \mathrm{~cm}(1 \mathrm{ft})$. The water-filled cavity extended more than $1 \mathrm{~m}(3.3 \mathrm{ft})$ horizontally into the rock formation. It appears that the cavity may have been formed by a combination of standing water from runoff gradually dissolving the rock substrate, freezing and thawing of the water in the winter, and perhaps by water seeping through fractures in the rock formation. In the rock formation above the tank, several small $0.03-\mathrm{m}^{3}\left(1-\mathrm{ft}^{3}\right)$ depressions appear to have been formed by similar processes, and water in these depressions may seep through the rock to. the tank below. Narrow erosion channels in the rock were also frequently observed in the area along fractures. No water quality measurements were taken. 


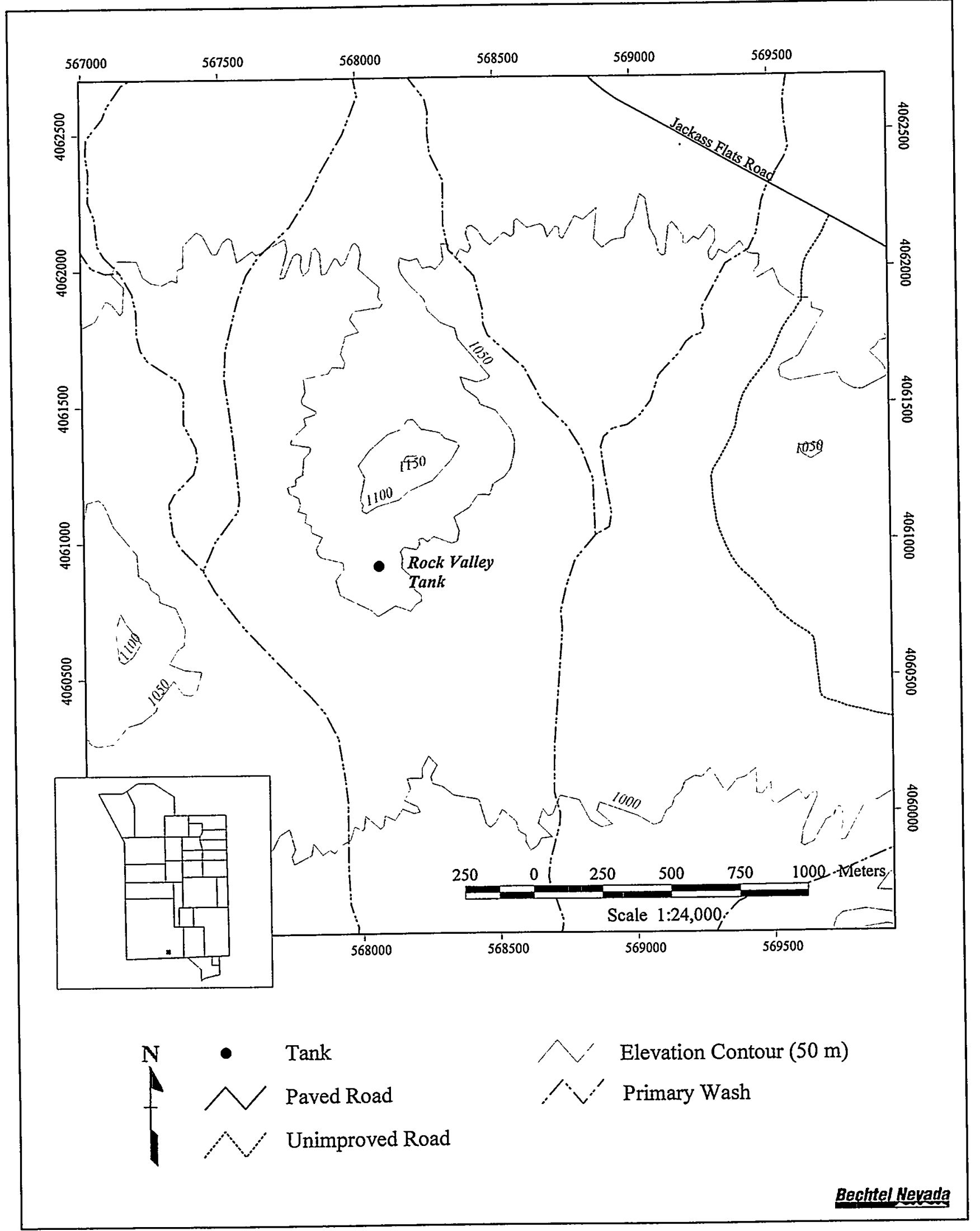

Figure 4-13 Location of Rock Valley Tank 


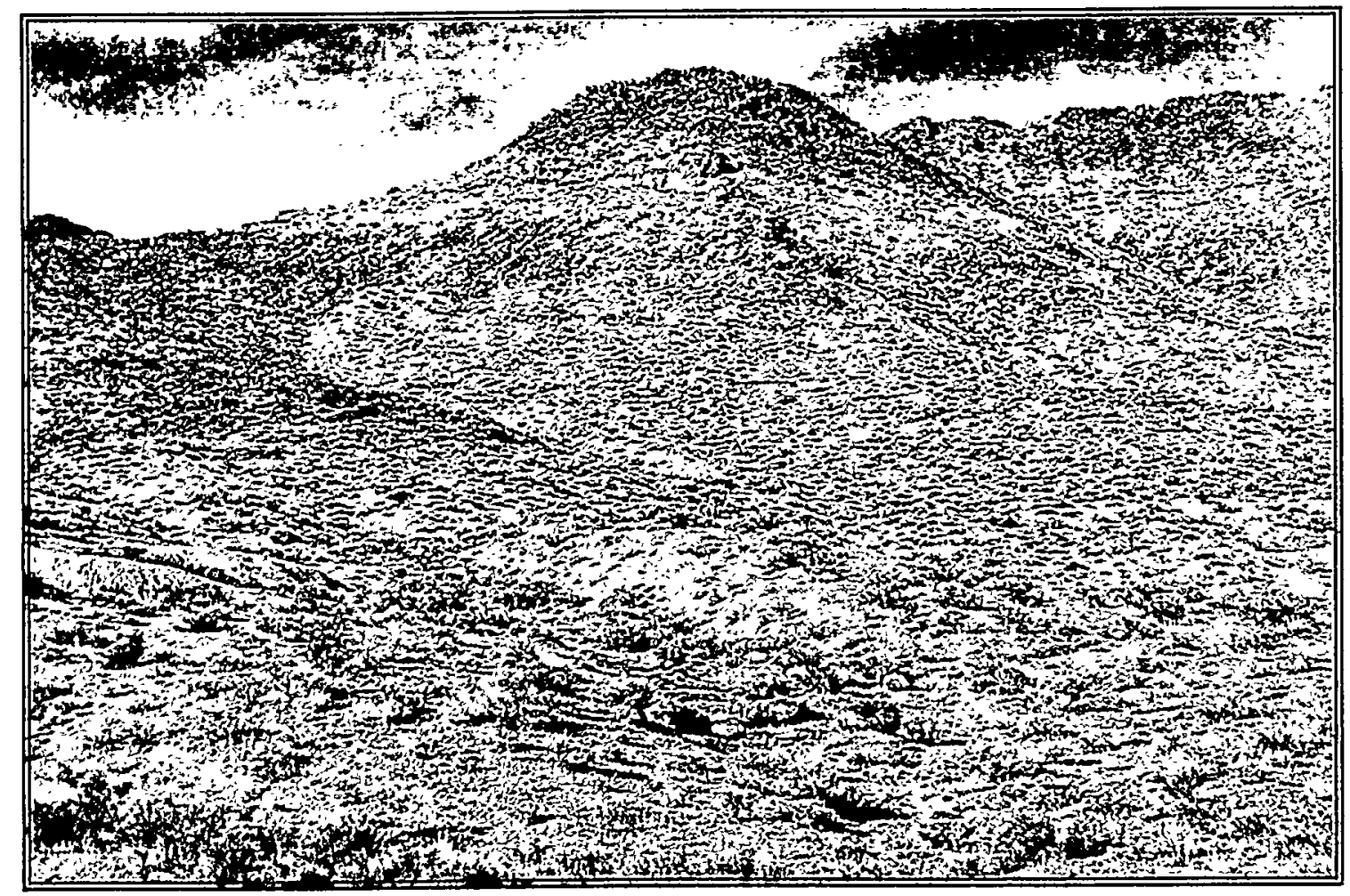

Photo 4-33 Habitat in the vicinity of Rock Valley Tank looking northwest on January 7, 1997

(WS346-24.TrF)

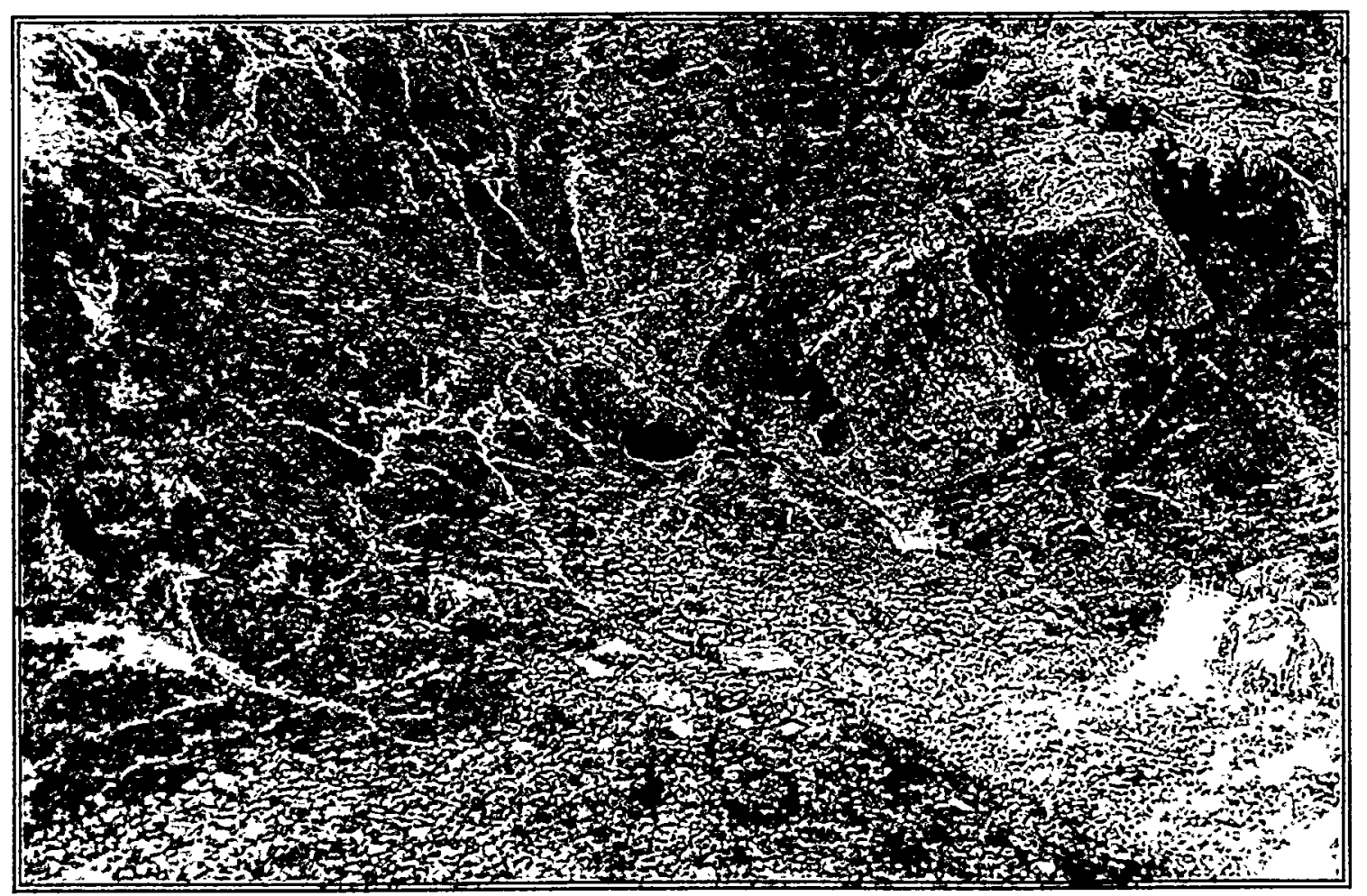

Photo 4-34 Tank opening (center) at Rock Valley Tank looking west on January 7, 1997 (WS340-20.TIF) 
Table 4-14 Rock Valley Tank wetland vegetation as surveyed on January 7, 1997

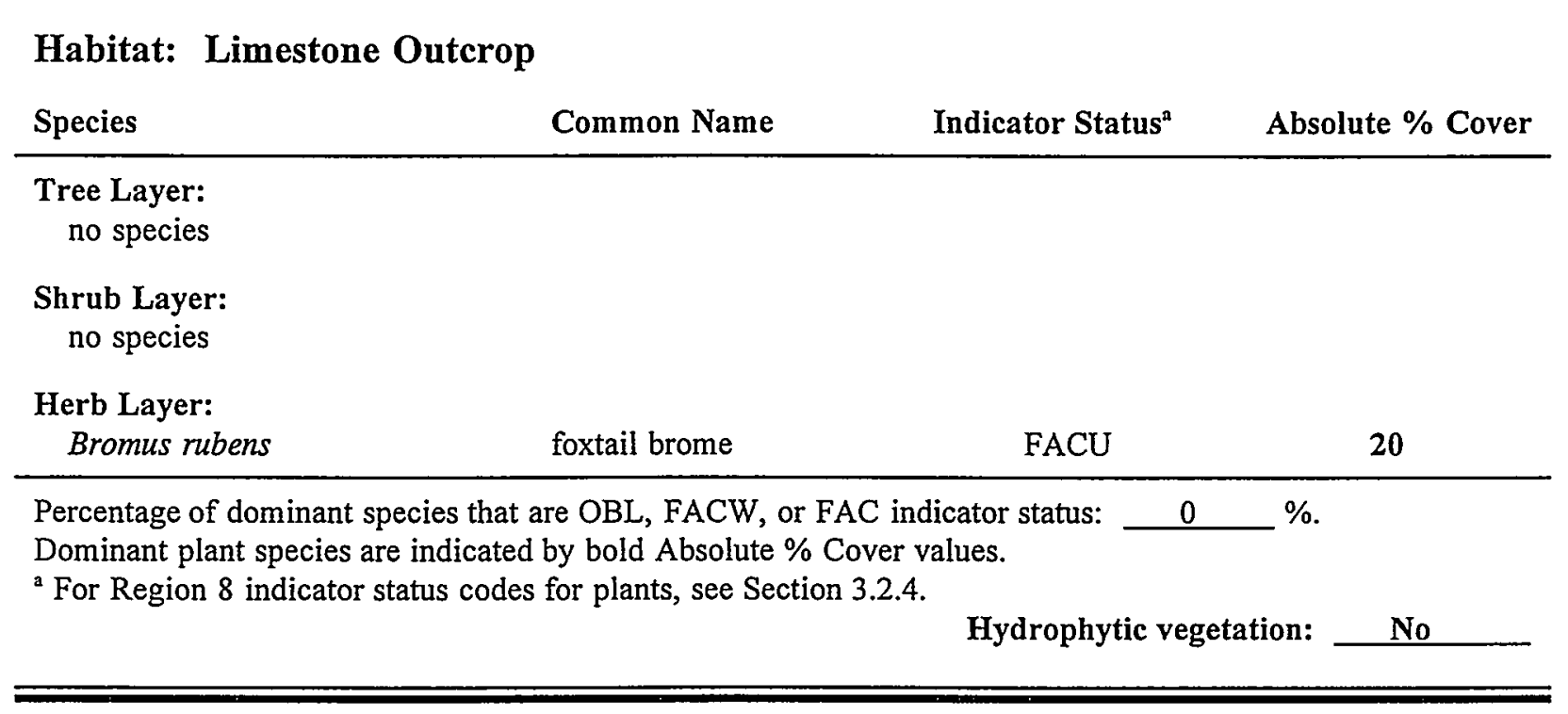

\subsubsection{Hydric Soils}

The Rock Valley Tank site lacked field indicators for hydric soils. The soil found below the tank was not saturated. The soil appeared dark, probably due to erosion of the dark limestone rock.

\subsubsection{Jurisdictional Wetland Determination}

Rock Valley Tank would probably not be considered a jurisdictional wetland because it lacked hydrophytic vegetation and hydric soils.

\subsubsection{Wildlife Use}

Wildlife known to use this site include bobcats, coyotes, and the desert tortoise (Greger and Romney, 1994). Coyote scat was abundant at the water source in January 1997.

\subsubsection{Tippipah Spring}

\subsubsection{Site Description and Historical Use}

Tippipah Spring lies at the base of a northeast ridge of Shoshone Mountain (Figure 4-14). This area was occupied by Native Americans who had winter camps near the spring, probably during the late 1800 s to early 1900 s (Stoffle et al., 1990a). An old stone building and foundation, scattered debris, pipes, a corral with a large water storage tank, and barbed wire fences attest that this area was once used by cattlemen and wild horse hunters (Worman, 1969). A gently sloping tunnel was excavated into the hillside, creating 

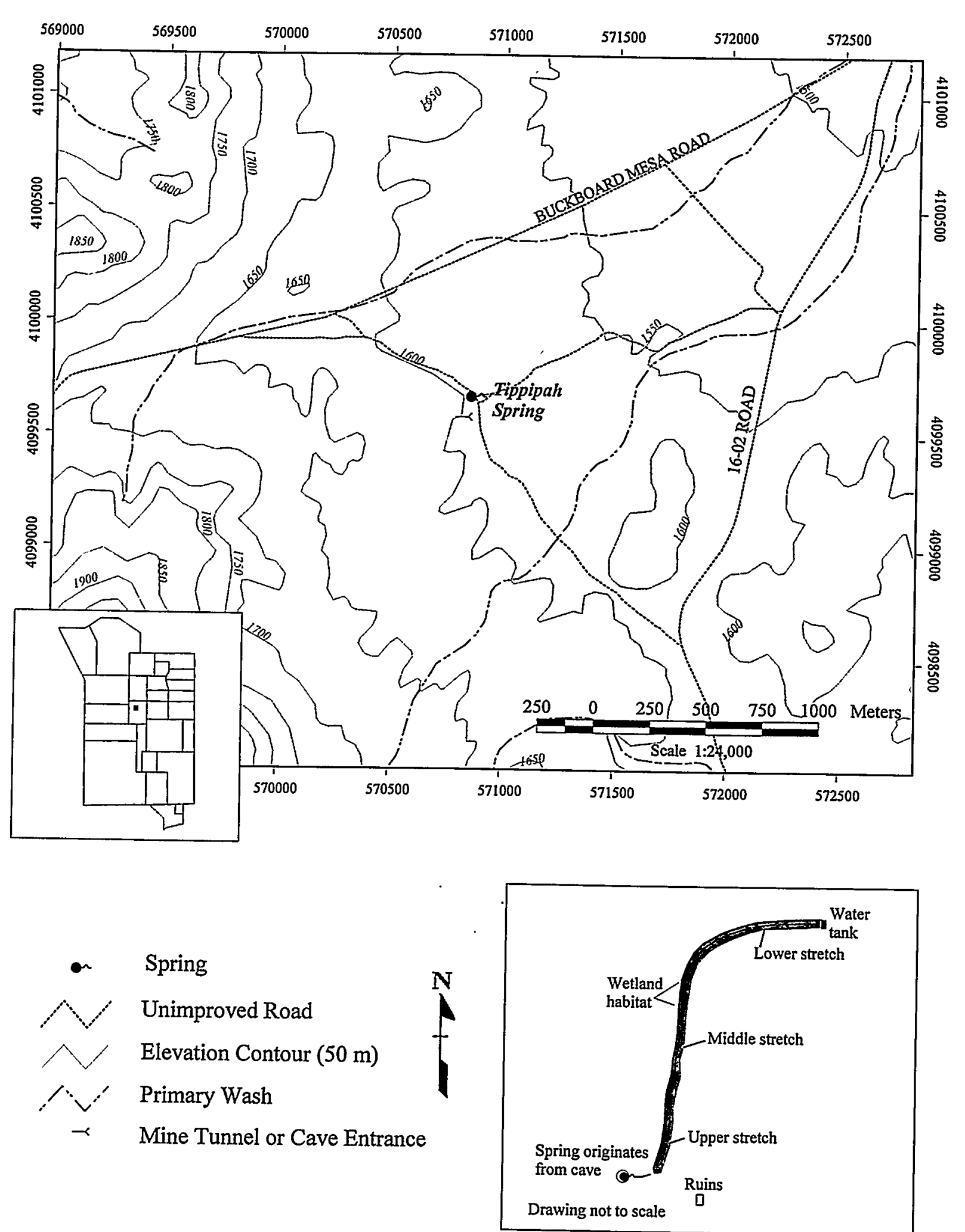

Bechtel Nevada

Figure 4-14 Location and sketch of Tippipah Spring 


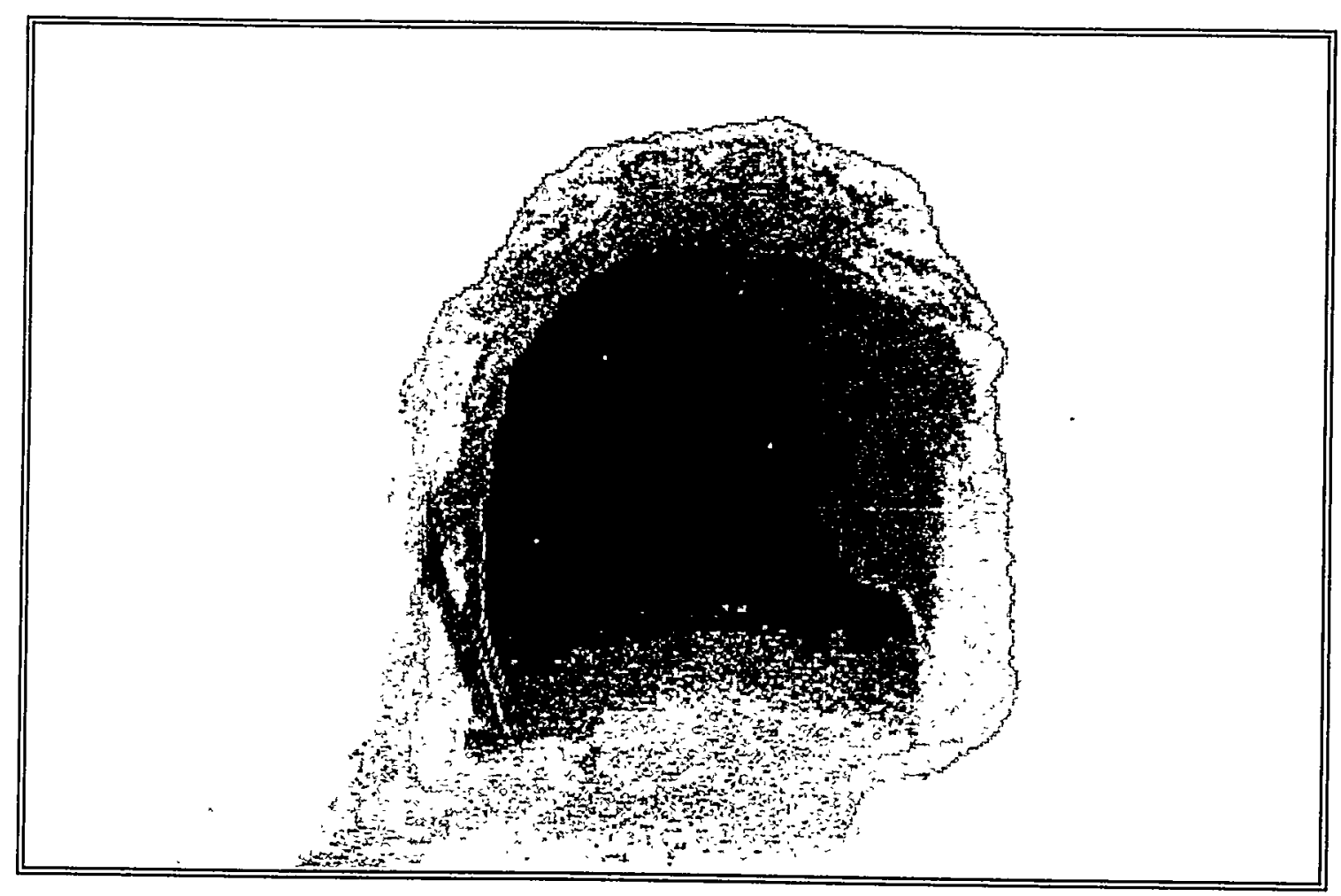

Photo 4-35 Tippipah Spring cave on October 5, 1988 (WS041-17.TIF)

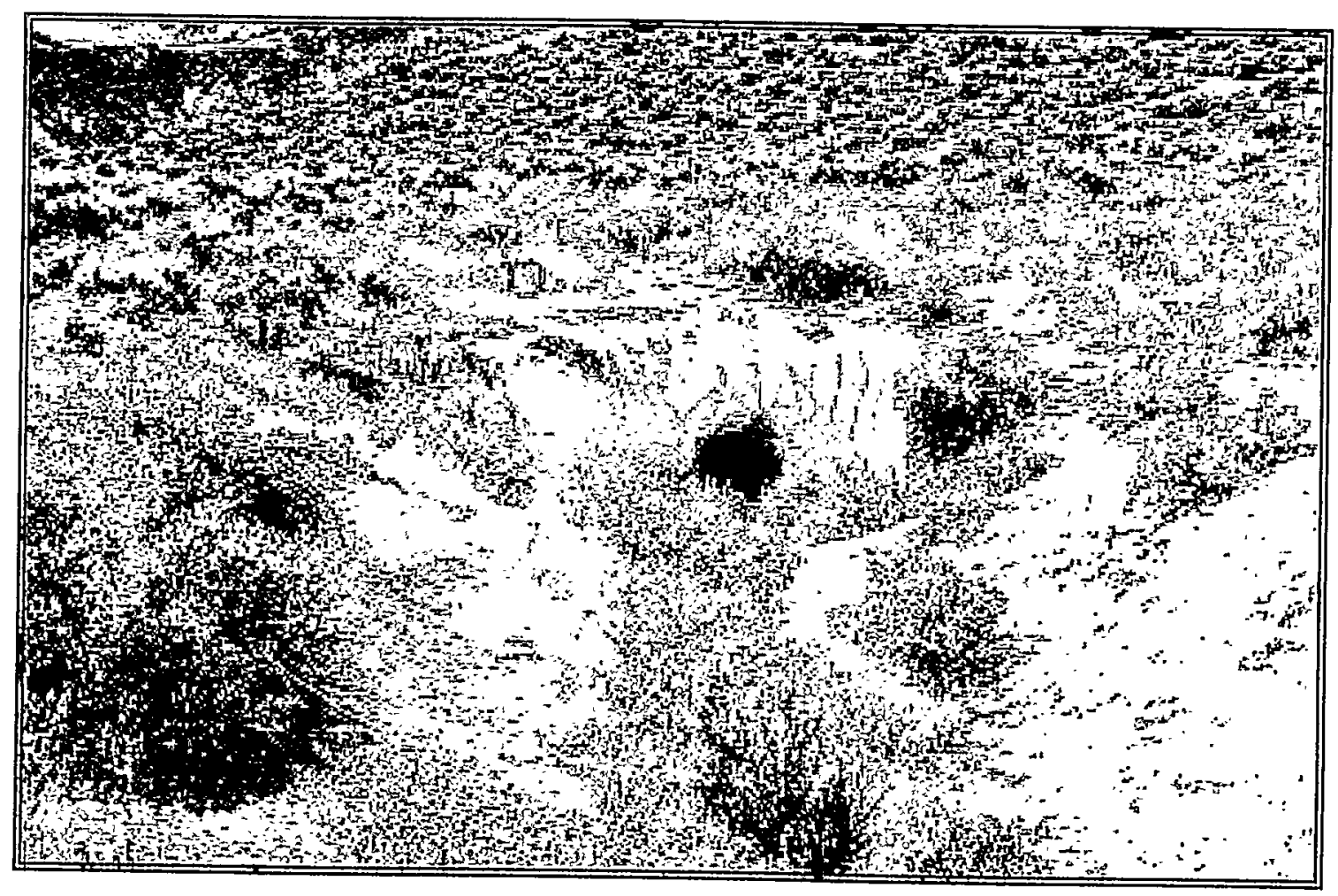

Photo 4-36 Habitat surrounding Tippipah Spring looking west on October 5, 1988 (WS501-01.TIF) 


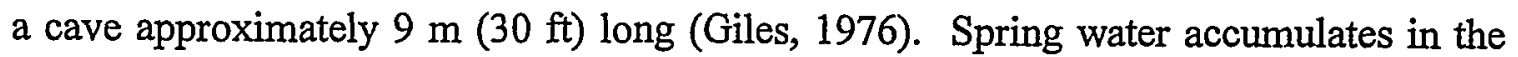
tunnel in a pool about $4 \mathrm{~m}$ (13 ft) from the cave entrance (Photo 4-35). The back of the

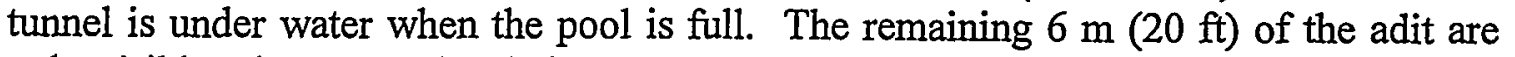
only visible when water levels in the pool are low. Water from the cave pool flows for about $40 \mathrm{~m}(130 \mathrm{ft})$ through subsurface strata and emerges in a long surface channel (Photo 4-36). The channel flows north for varying distances depending on seasonal rainfall (Figure 4-14). It appears that the upper portion of the spring channel has been excavated periodically by man judging from the mounds of dirt on either side of the channel. The upper spring channel was nearly dry during the Fall of 1990 resulting in a visible decline in cover of riparian plants (Photo 4-37). The same habitat showed recovery of the wetland vegetation during 1992 (Photo 4-38), a wet year which broke a three-year drought period.

\subsubsection{Hydrophytic Vegetation}

During June 1996, the wetland vegetation consisted of a narrow, linear corridor that extended for $170 \mathrm{~m}(558 \mathrm{ft})$. Three locations along its length were sampled: upper channel, mid-channel (Photo 4-39) and lower channel (Photo 4-40). Eleven species of wetland plants were recorded at these observation points. The dominant wetland species were Baltic rush, biennial cinquefoil, annual rabbitsfoot grass, and water speedwell (Tables 4-15 to 4-17). There were minor differences in the plant communities sampled at the three observation points. The number and composition of wetland plant species varies along the watercourse with distance from the spring source. Annual rabbitsfoot grass was present in the lower two sections and was not observed in the upper section. Biennial cinquefoil was present only in the lower channel. Other species within the jurisdictional wetland boundary were trefoil (Lotus sp.) and southern cattail. Louisiana sagewort and rubber rabbitbrush were encroaching on the edge of the wetland boundary. The overall wetland habitat was dominated by Baltic rush. The total surface area of this wetland, as defined by wetland vegetation, was approximately $500 \mathrm{~m}^{2}\left(5,380 \mathrm{ft}^{2}\right)$ (Table 5-1, Section 5.0). Common upland plant species in the area included big sagebrush, blackbrush, rubber rabbitbrush, fourwing saltbush, Nevada jointfir, and desert bitterbrush.

Surveys from the observation points in the upper channel, mid-channel, and lower channel all determined that 100 percent of the dominant plant species were wetland species indicating that Tippipah Spring has hydrophytic vegetation (Tables 4-15 to 4-17). However, no vascular plants were observed at the spring pool, possibly because the pool lies within the cave where light is limited.

\subsubsection{Wetland Hydrology and Water Quality}

Field indicators of wetland hydrology were restricted to the cave pool and the three channel areas. Surface water was present at Tippipah Spring during the wetland survey in June 1996. The estimated area of surface inundation was approximately $190 \mathrm{~m}^{2}(2,044$ $\mathrm{ft}^{2}$ ) (Table 5-1, Section 5.0). Flow rates in the mid channel were estimated to be approximately $2.7 \mathrm{\ell} / \mathrm{min}(0.7 \mathrm{gal} / \mathrm{min})$ on November 15,1996 . Water quality measurements were taken at the open channel pool in June, September, and November 1996. Measurements were taken at the cave pool in September and November 1996. Data are presented in Table 5-2 (Section 5.0). 


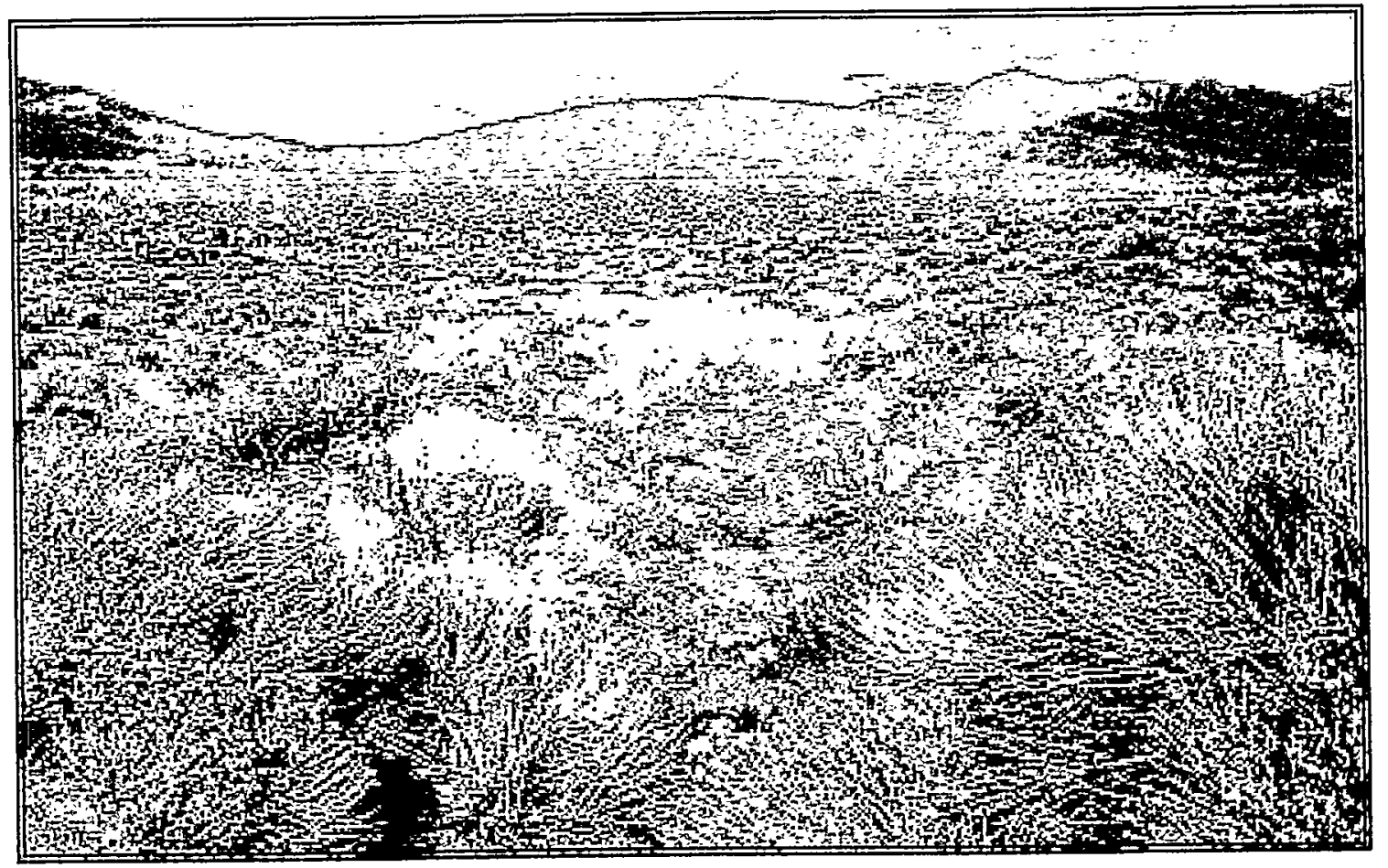

Photo 4-37 Tippipah Spring channel nearly dry, with drought-stressed vegetation, looking north on November 29, 1990 (WS231-03.TIF)

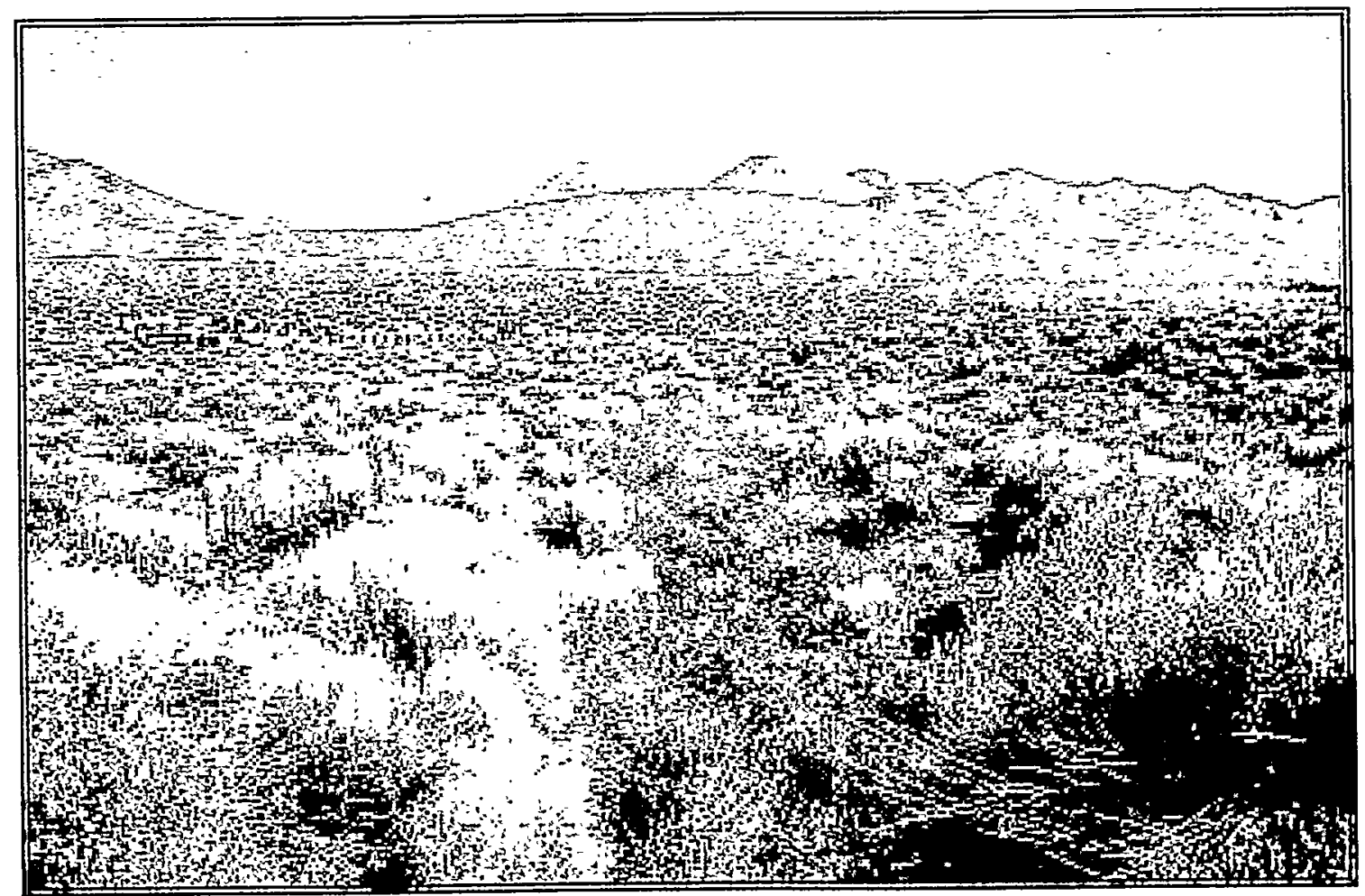

Photo 4-38 Upper reach of Tippipah Spring channel showing recovery of vegetation following drought, looking north on June 4, 1992 (WS310-09.TIF) 


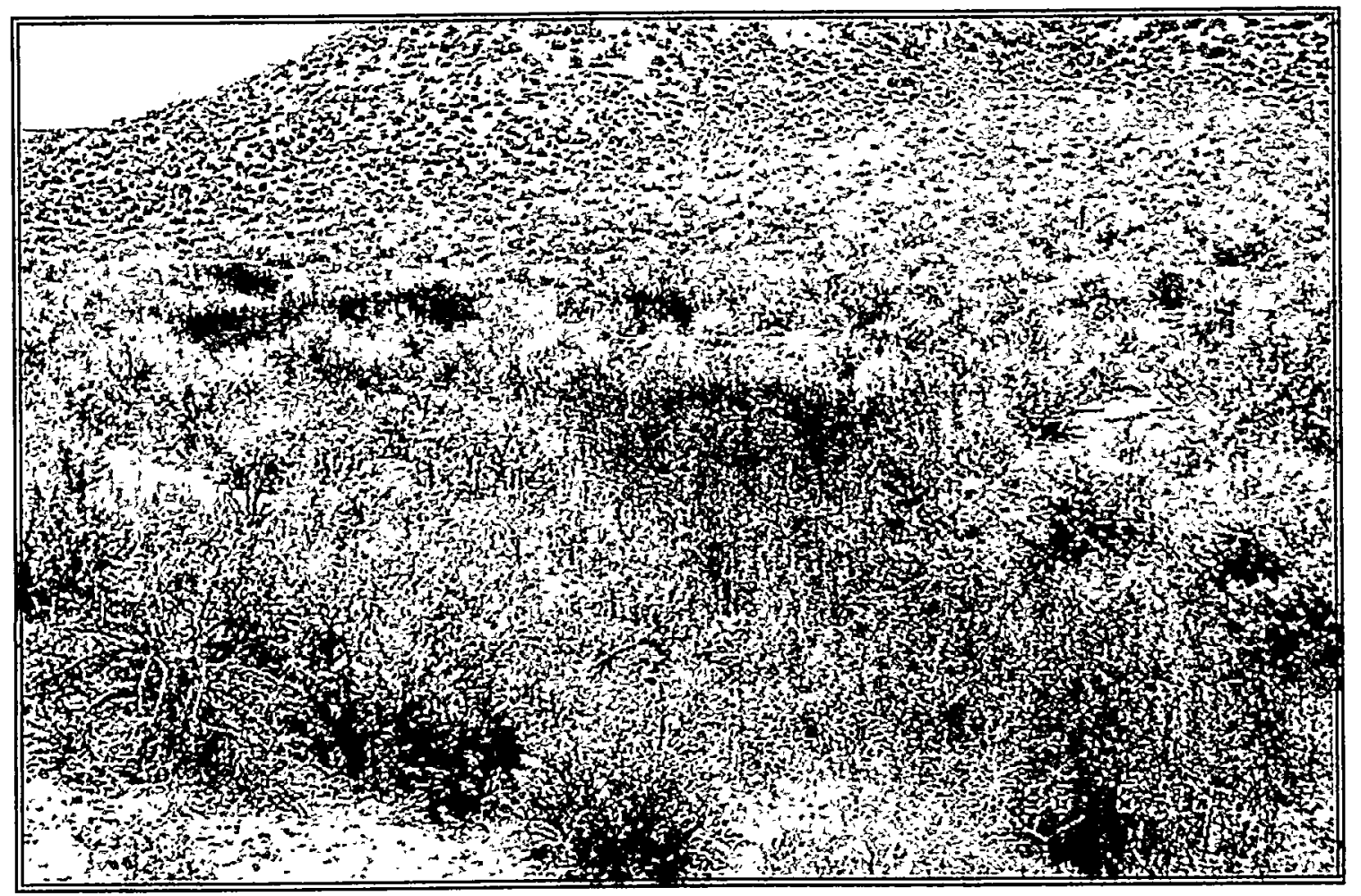

Photo 4-39 Middle reach of Tippipah Spring channel looking southwest on June 18, 1996 (WS341-25.TIF)

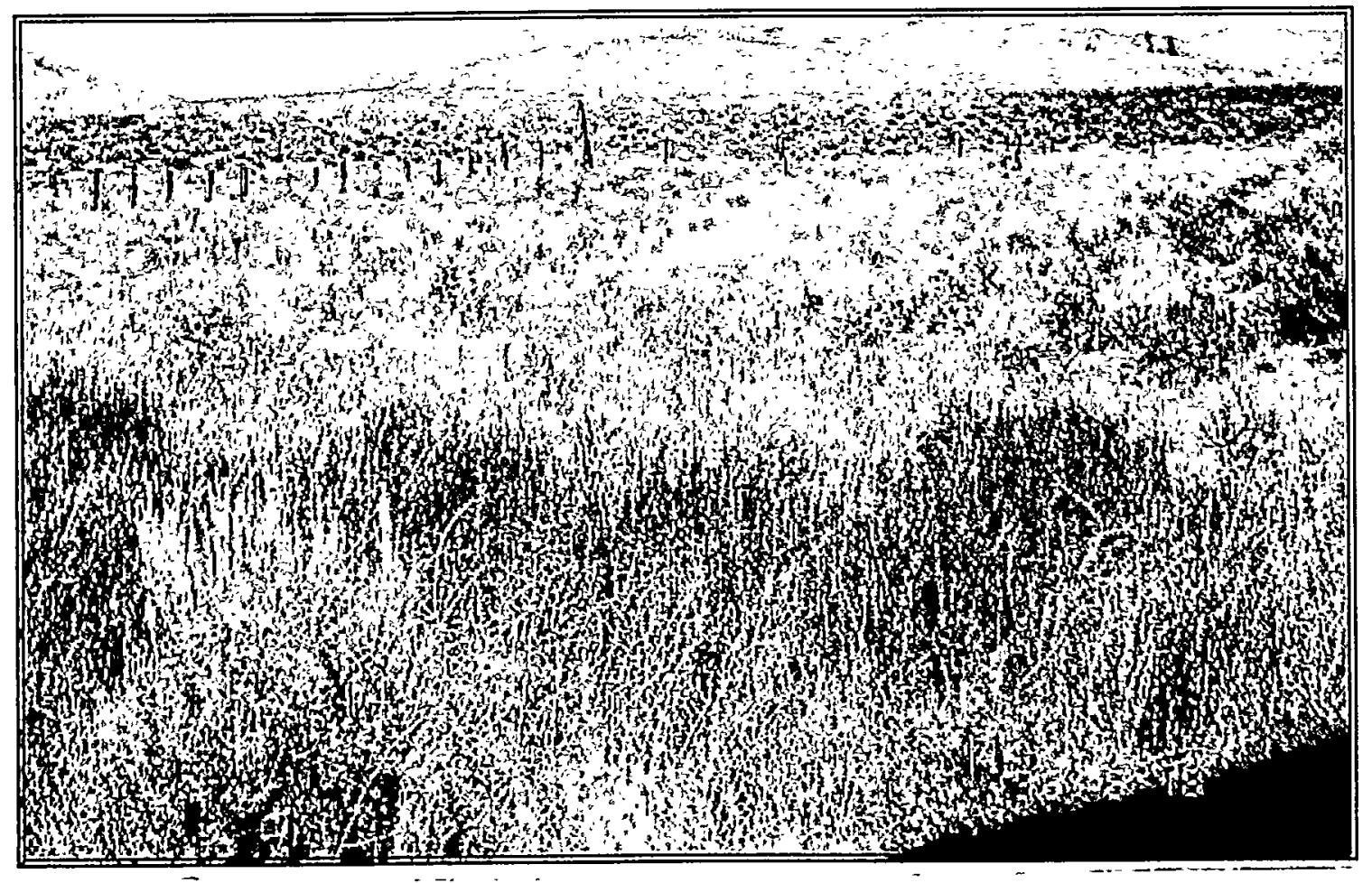

Photo 4-40 Lower reach of Tippipah Spring channel looking northwest on June 18, 1996 (WS341-24.TIF) 
Table 4-15 Tippipah Spring wetland vegetation as surveyed on June 18, 1996

\section{Habitat: Upper Stretch of the Spring Channel}

\begin{tabular}{|c|c|c|c|}
\hline Species & Common Name & Indicator Status $\mathrm{s}^{\mathrm{a}}$ & Absolute \% Cover \\
\hline \multicolumn{4}{|l|}{$\begin{array}{r}\text { Tree Layer: } \\
\text { no species }\end{array}$} \\
\hline \multicolumn{4}{|l|}{$\begin{array}{l}\text { Shrub Layer: } \\
\text { no species }\end{array}$} \\
\hline \multicolumn{4}{|l|}{ Herb Layer: } \\
\hline Carex praegracilis & clustered field sedge & FACW- & 2 \\
\hline $\begin{array}{l}\text { Eleocharis palustris } \\
\text { Heliomeris multiflora var. }\end{array}$ & common spikerush & OBL & $\operatorname{Tr}$ \\
\hline nevadensis & Nevada goldeneye & NL & $\operatorname{Tr}$ \\
\hline Juncus balticus & Baltic rush & FACW & 49 \\
\hline Polypogon monspeliensis & $\begin{array}{l}\text { annual rabbitsfoot } \\
\text { grass }\end{array}$ & FACW+ & $\operatorname{Tr}$ \\
\hline Veronica anagallis-aquatica & water speedwell & OBL & 49 \\
\hline
\end{tabular}

Percentage of dominant species that are $\mathrm{OBL}, \mathrm{FACW}$, or FAC indicator status: $100 \%$

Dominant plant species are indicated by bold Absolute \% Cover values. $\operatorname{Tr}=$ trace, $<1 \%$ absolute cover.

${ }^{a}$ For Region 8 indicator status codes for plants, see Section 3.2.4. 
Table 4-16 Tippipah Spring wetland vegetation as surveyed on June 18, 1996

\section{Habitat: Middle Stretch of Spring Channel}

\begin{tabular}{|c|c|c|c|}
\hline Species & Common Name & $\begin{array}{l}\text { Indicator } \\
\text { Status }^{\mathbf{a}}\end{array}$ & Absolute \% Cover \\
\hline \multicolumn{4}{|l|}{$\begin{array}{r}\text { Tree Layer: } \\
\text { no species }\end{array}$} \\
\hline \multicolumn{4}{|l|}{$\begin{array}{l}\text { Shrub Layer: } \\
\text { no species }\end{array}$} \\
\hline \multicolumn{4}{|l|}{ Herb Layer: } \\
\hline Bromus rubens & foxtail brome & FACU & $\operatorname{Tr}$ \\
\hline Bromus tectorum & cheatgrass & NL & 2 \\
\hline Castilleja sp. & $\begin{array}{l}\text { unidentified Indian } \\
\text { paintbrush }\end{array}$ & UNKN & $\operatorname{Tr}$ \\
\hline Deschampsia danthonioides & annual hairgrass & FACW & $\operatorname{Tr}$ \\
\hline Eleocharis parishii & Parish's spikerush & OBL & $\operatorname{Tr}$ \\
\hline Epilobium glaberrimum & smooth willowweed & FACW & 2 \\
\hline Heliomeris multiflora var. & & & \\
\hline nevadensis & Nevada goldeneye & NL & 2 \\
\hline Juncus balticus & Baltic rush & FACW & 40 \\
\hline Juncus longistylis & longstyle rush & FACW+ & $\operatorname{Tr}$ \\
\hline Lactuca serriola & prickly lettuce & FACU & 2 \\
\hline Polypogon monspeliensis & annual rabbitsfoot grass & FACW+ & 30 \\
\hline Verbena bracteata & bigbract verbena & FACU & 2 \\
\hline Veronica anagallis-aquatica & water speedwell & OBL & 20 \\
\hline
\end{tabular}

Percentage of dominant species that are OBL, FACW, or FAC indicator status:

100 $\%$.

Dominant plant species are indicated by bold Absolute \% Cover values. $\mathrm{Tr}=\operatorname{trace},<1 \%$ absolute cover.

${ }^{\mathrm{a}}$ For Region 8 indicator status codes for plants, see Section 3.2.4.

Hydrophytic vegetation: Yes 
Table 4-17 Tippipah Spring wetland vegetation as surveyed on June 18, 1996

\section{Habitat: Lower Stretch of Spring Channel}

\begin{tabular}{|c|c|c|c|}
\hline Species & Common Name & Indicator Status ${ }^{2}$ & Absolute \% Cover \\
\hline \multicolumn{4}{|l|}{$\begin{array}{l}\text { Tree Layer: } \\
\text { no species }\end{array}$} \\
\hline \multicolumn{4}{|l|}{$\begin{array}{l}\text { Shrub Layer: } \\
\text { no species }\end{array}$} \\
\hline \multicolumn{4}{|l|}{ Herb Layer: } \\
\hline Bromus tectorum & cheatgrass & NL & $\operatorname{Tr}$ \\
\hline $\begin{array}{l}\text { Erodium cicutarium } \\
\text { Heliomeris multiflora }\end{array}$ & redstem stork's bill & NL & $\operatorname{Tr}$ \\
\hline var. nevadensis & Nevada goldeneye & NL & 2 \\
\hline Juncus balticus & Baltic rush & FACW & 40 \\
\hline Lactuca serriola & prickly lettuce & FACU & 2 \\
\hline Polypogon monspeliensis & $\begin{array}{l}\text { annual rabbitsfoot } \\
\text { grass }\end{array}$ & $\mathrm{FACW}+$ & 10 \\
\hline Potentilla biennis & biennial cinquefoil & FAC & 20 \\
\hline Verbena bracteata & bigbract verbena & FAC & 1 \\
\hline Veronica anagallis-aquatica & water speedwell & OBL & 25 \\
\hline
\end{tabular}

Percentage of dominant plant species that are OBL, FACW, or FAC indicator status: $\frac{100}{\% \text {. }}$

Dominant plant species are indicated by bold values for Absolute \% Cover. $\mathrm{Tr}=\operatorname{trace},<1 \%$ absolute cover.

${ }^{\mathrm{a}}$ For Region 8 indicator status codes for plants, see Section 3.2.4).

Hydrophytic vegetation:

\subsubsection{Hydric Soils}

Field indicators of hydric soils were also restricted to areas at the cave pool and the three channel areas where soils appeared to be saturated for seven days or more during the plant growing season, indicating the presence of hydric soil. Several soil pits were dug to examine soils for other field indicators for hydric soils. No evidence of soil mottling was found. Because the upper spring outflow area appears to have been dug out or possibly blasted due to the presence of rock immediately adjacent to the channel, this site may represent an atypical situation for soils evaluation.

\subsubsection{Determination of Jurisdictional Status}

The three channel areas at Tippipah Spring would probably qualify as jurisdictional wetlands because they had field indicators for all three required parameters: hydrophytic vegetation, wetland hydrology, and hydric soils. The cave pool lacks hydrophytic vegetation and would probably not be considered as a jurisdictional wetland. It may, however, be protected under the CWA as waters of the United States. 


\subsubsection{Wildlife Use}

Wildlife species observed at Tippipah Spring include chukar, coyotes, Gambel's quail, southern pocket gophers (Thomomys umbrinus), black-tailed jackrabbits, mourning doves, mule deer, raptors, and about 15 species of passerine birds. Invertebrates were abundant and included ostracods (seed shrimp), copepods (crustaceans), and aquatic insects.

\subsubsection{Tongue Wash Tank}

\subsubsection{Site Description and Historical Use}

Tongue Wash Tank is located in rock ledges southeast of Rainier Mesa within $500 \mathrm{~m}$ (1,641 ft) of the intersection of Holmes Road and Rainier Mesa Road (Figure 4-15). The cave entrance is about $2 \mathrm{~m}(6 \mathrm{ft})$ high by $1.5 \mathrm{~m}(5 \mathrm{ft})$ wide, large enough to permit entry by people or large animals (Photo 4-41). Native American use of the site is certain due to the petroglyphs on the rocks at the site. There was no evidence of human disturbance or modification of the hydrology of the site.

\subsubsection{Hydrophytic Vegetation}

No wetland or upland plants were observed at the observation point located at the tank on September 10, 1996. A small 2- $\mathrm{m}^{2}\left(22-\mathrm{ft}^{2}\right)$ vegetated area with soil fines and upland plants existed several meters downslope from the tank. Plant species in the surrounding upland included big sagebrush, mormon tea, Utah juniper, and singleleaf pinyon.

\subsubsection{Hydrology}

The Tongue Wash Tank exists in a natural cave in a tuff rock formation. Water appears to collect from internal fractures within the tuff. The pool of water in the tank measured about $3 \mathrm{~m}(10 \mathrm{ft})$ long by $1.5 \mathrm{~m}(5 \mathrm{ft})$ wide and $25 \mathrm{~cm}(10$ in) deep. A dark water line mark observed in the tank indicates long-standing water and a pool depth of $46 \mathrm{~cm}$ (18 in) when full (Photo 4-42). There was no water flow observed from the tank; however, water line marks indicate that water could reach a level that may result in an overflow of the tank. No water quality measurements were taken.

\subsubsection{Hydric Soils}

The Tongue Wash Tank site lacks hydric soils because the surface water is confined to rock substrate.

\subsubsection{Jurisdictional Wetland Determination}

Tongue Wash Tank would probably not be considered a jurisdictional wetland because it lacked hydrophytic vegetation and hydric soils. The water in the tank may, however, be considered waters of the United States protected under the CWA. 


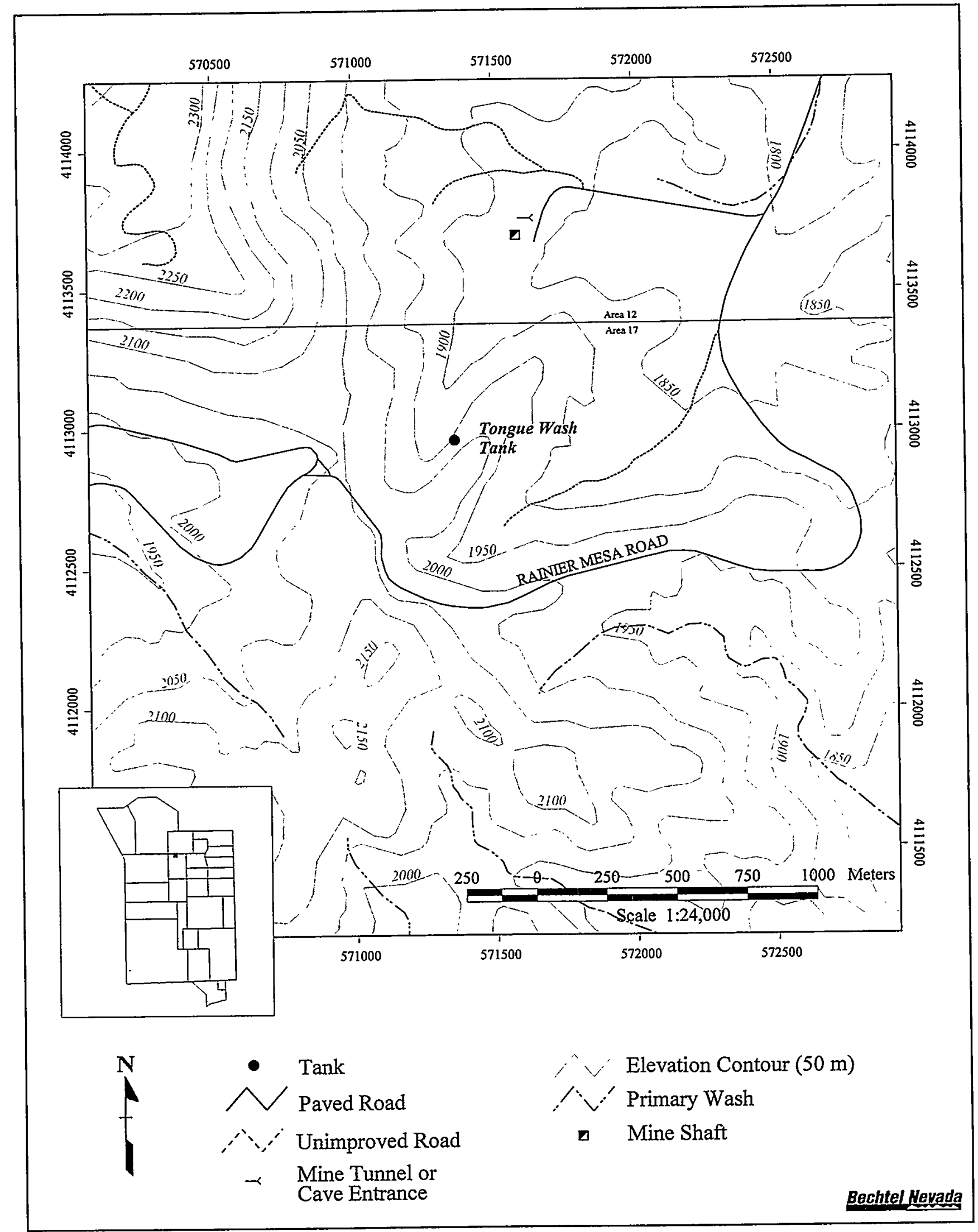

Figure 4-15 Location of Tongue Wash Tank 


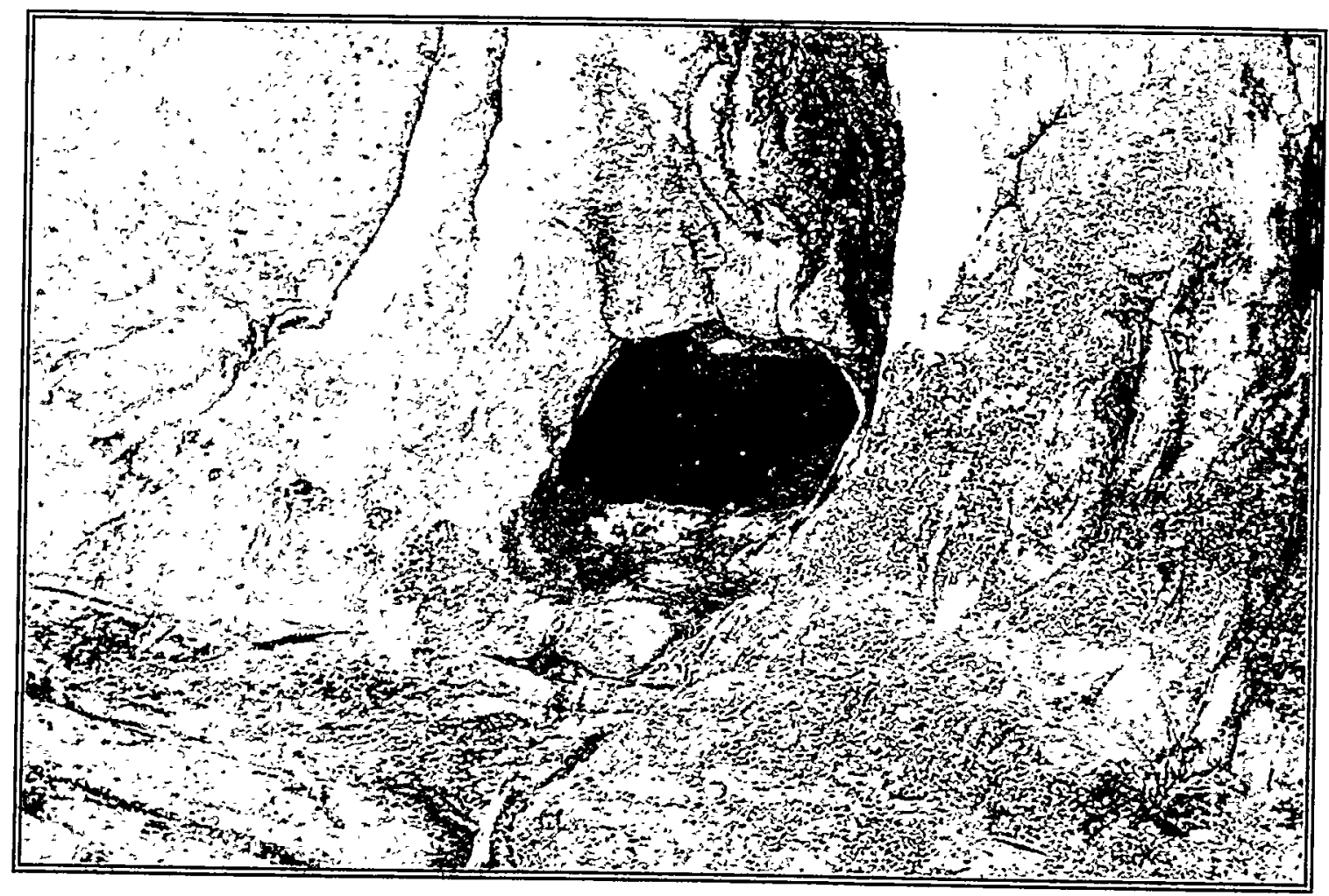

Photo 4-41 Cave opening at Tongue Wash Tank looking south on January 10, 1997 (WS340-24.TIF)

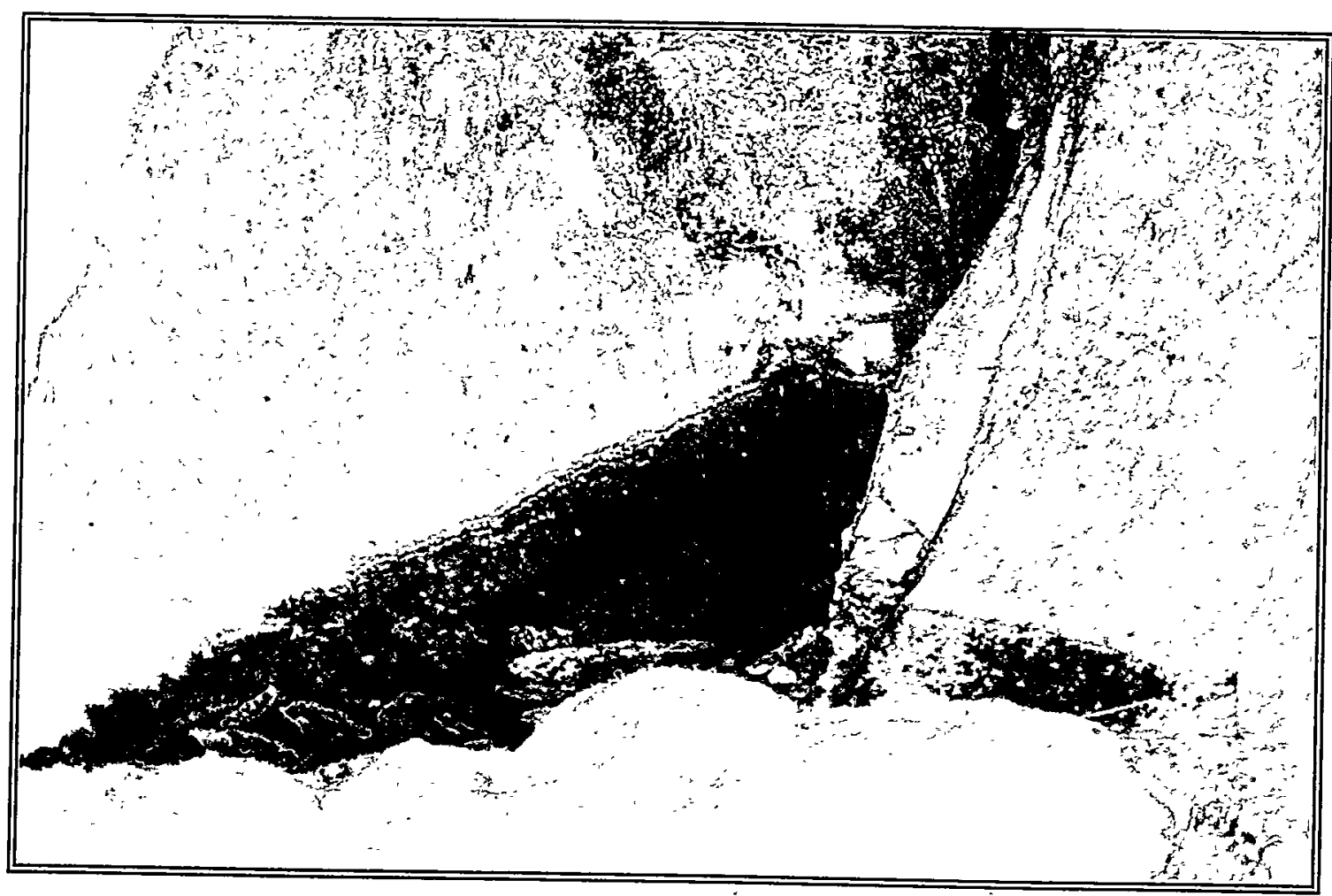

Photo 4-42 Tank inside cave at Tongue Wash Tank on January 10, 1997 (WS340-22.TIF) 


\subsubsection{Wildlife Use}

Little is known about wildlife use of Tongue Wash Tank. Several species of birds, including ravens, were observed drinking from the water tank on September 10, 1996.

\subsubsection{Topopah Spring}

\subsubsection{Site Description and Historical Use}

Topopah Spring is located on a south-facing slope in a box canyon of Topopah Wash southwest of Shoshone Peak (Figure 4-16). Native Americans used this area as a winter camp during the late 1800s or early 1900s (Stoffle et al., 1990a). A rock shelter exists on the hill slope opposite the spring. Remnants of human habitation including a concrete foundation, pipes, and water tanks occur immediately to the west of the spring. Evidence of some excavation exists on the hillside meadow where some seeps emanate (Photo 4-43). A cave pool (Photo 4-44) occurs at the base of a small man-made tunnel (Worman, 1969). A pipe was installed in the ground about $15 \mathrm{~m} \mathrm{(49} \mathrm{ft)} \mathrm{downslope} \mathrm{from}$ the cave pool. Water flows out the end of this pipe forming a second, much smaller shallow pool (Photo 4-45). The upland vegetation near the spring was modified by a wildfire burn that occurred in Topopah Wash many years ago.

\subsubsection{Hydrophytic Vegetation}

Two observation points at Topopah Spring were sampled: the area around the cave pool and the hillside meadow. These two areas form a discontinuous wetland site. A total of 11 wetland species of plants were recorded from both areas at Topopah Spring (Tables 4-18 and 4-19). There were differences in the vegetation between the two areas sampled. The cave pool area had fewer plant species (10) compared to the hillside meadow (17). Species composition (based on percent absolute cover and dominance) was also different between sites. The cave pool area had three dominant wetland species including seep monkeyflower, willow dock, and water speedwell. The dominant wetland species on the hillside meadow included Baltic rush and Rocky Mountain rush (Juncus saximontanus) (Photo 4-46). Eleven species in the sample area of the hillside meadow were not present at the cave pool sample area. Upland species in the area near the spring habitats included Utah serviceberry (Amelanchier utahensis), big sagebrush, mormon tea, basin wildrye, desert almond (Prunus fasciculata), Stansbury cliffrose, Gambel's oak, and skunkbush sumac.

One hundred percent of the dominant plant species in the cave pool area (Table 4-18) were hydrophytic species, indicating that field indicators for hydrophytic vegetation are present at this area. At the hillside meadow sample area, only two of the four dominant plants (50 percent) were wetland species (Table 4-19). Normally, greater than 50 percent of the dominant plants must be hydrophytic to conclude that field indicators for hydrophytic vegetation are present. However, it is appropriate to conclude that such field indicators were present at the hillside meadow area because hydrophytic species at this site (the nine species categorized as FAC, FACW, or OBL [Table 4-19]) comprised 63 percent of the cover, whereas nonhydrophytic species comprised only 43 percent of the cover. It is therefore concluded that Topopah Spring has field indicators for hydrophytic vegetation 


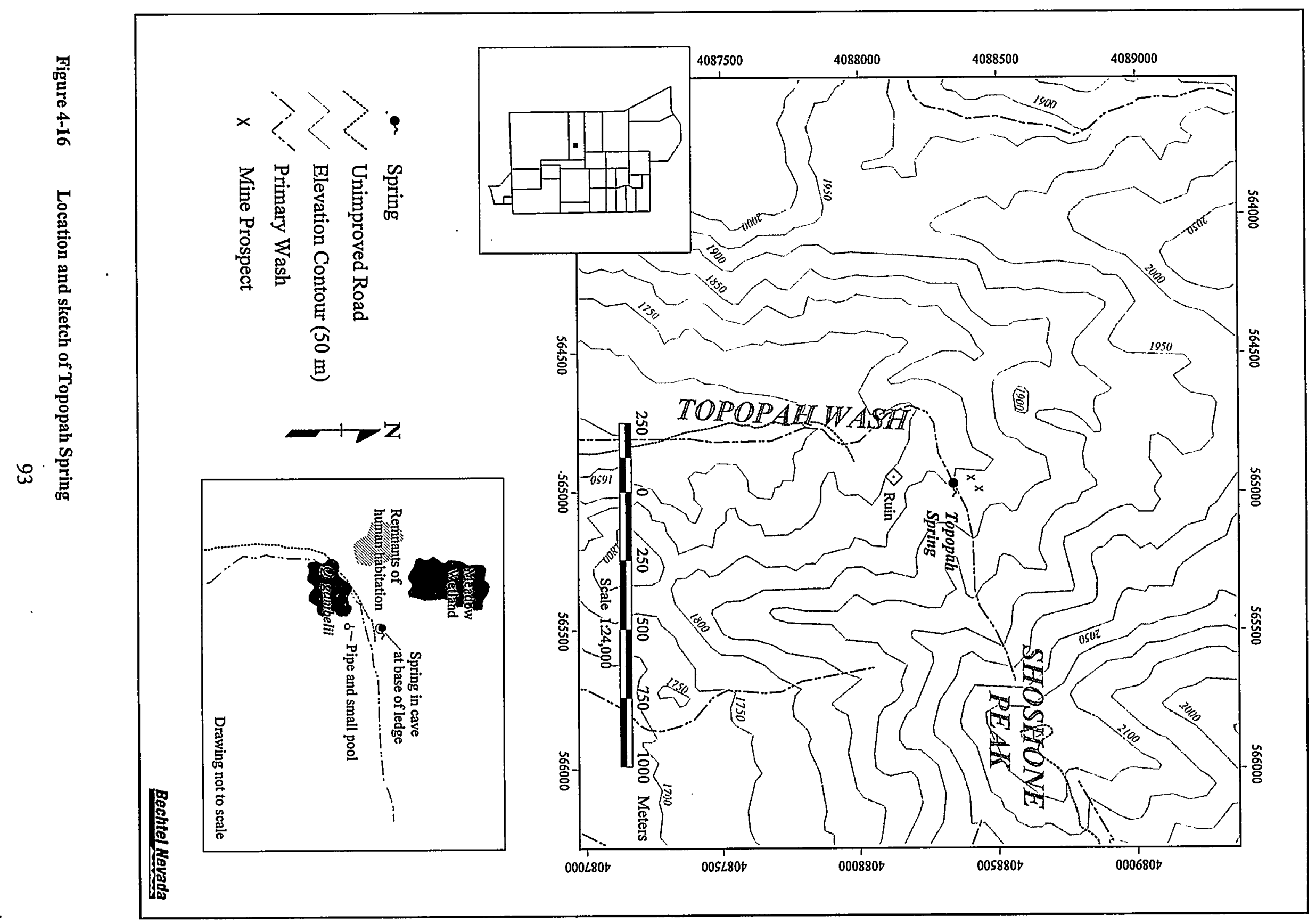




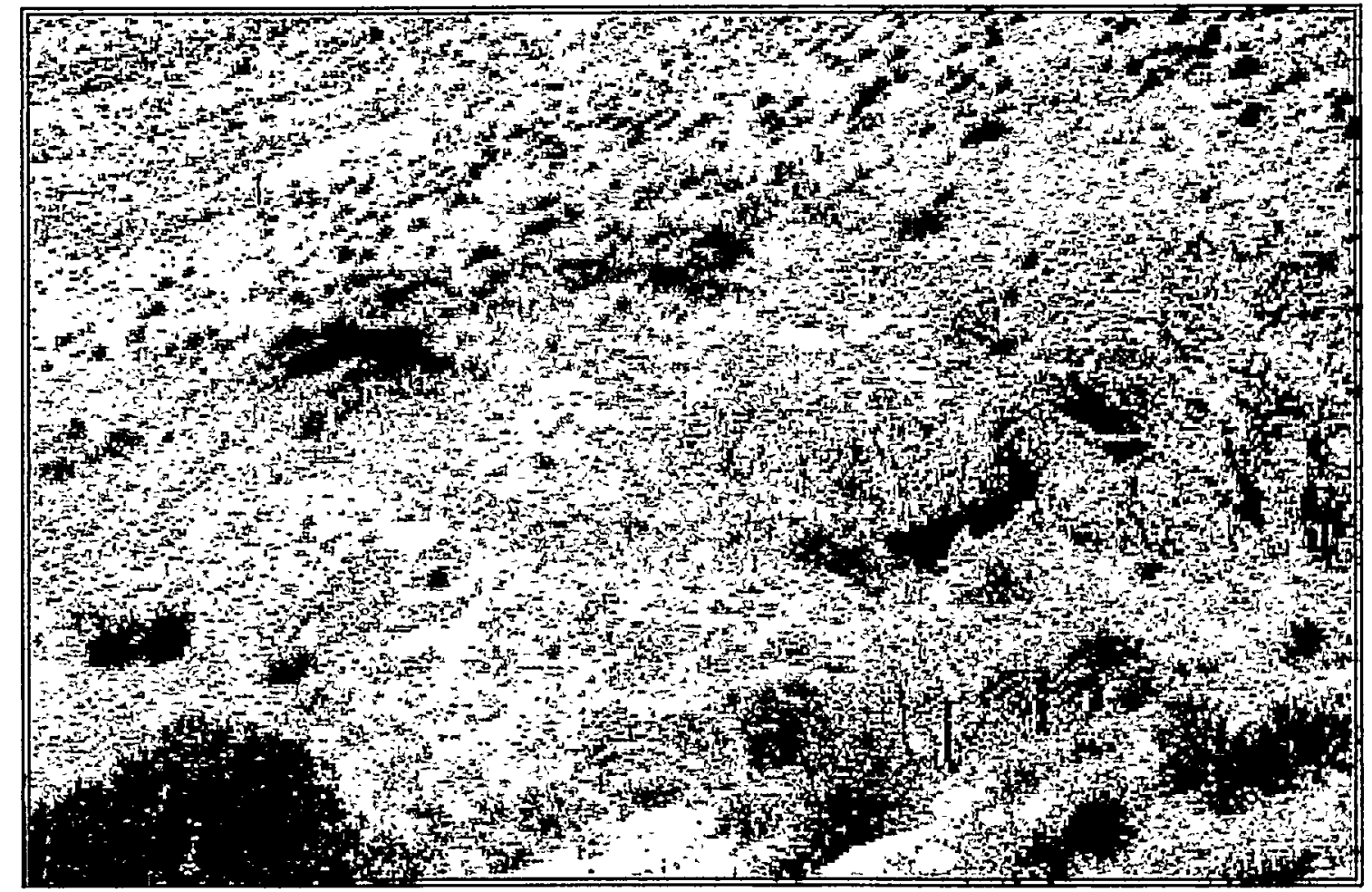

Photo 4-43 Topopah Spring wetland area looking north on June 27, 1988 (WS012-13.TIF)

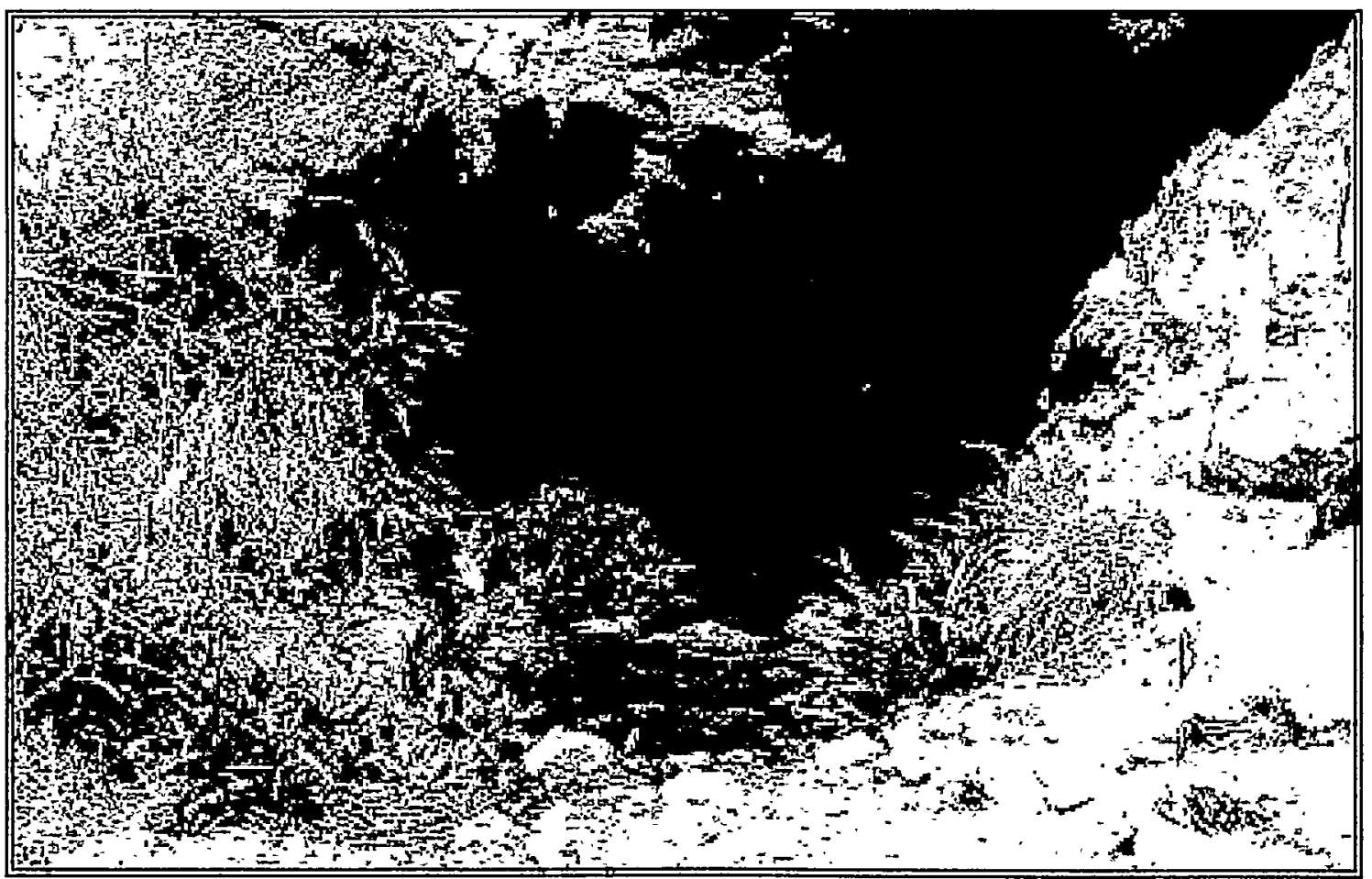

Photo 4-44 Vegetation of Topopah Spring cave pool on April 18, 1989 (WS109-15.TIF) 


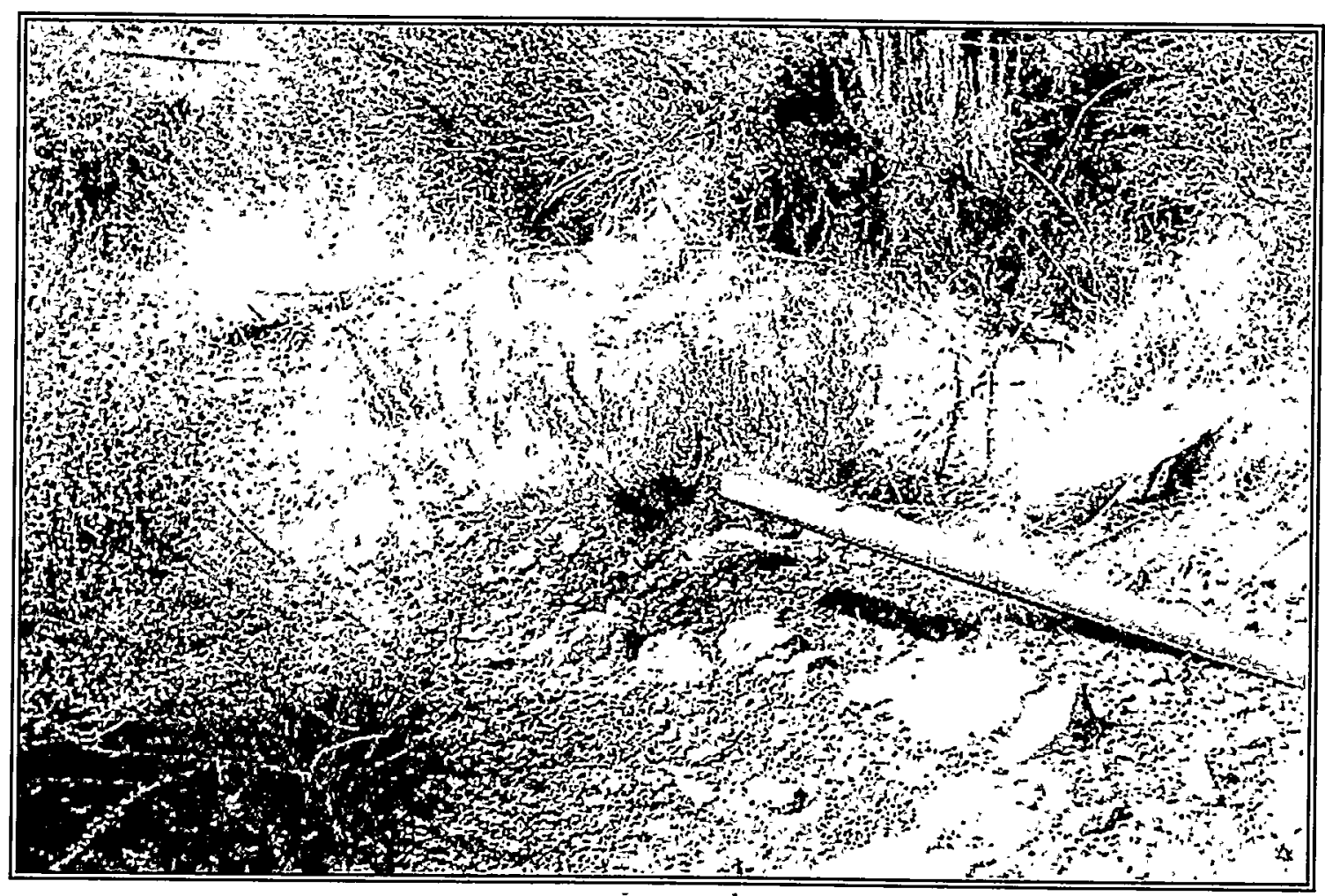

Photo 4-45 Outflow pipe at Topopah Spring on September 9, 1996 (WS340-10.TIF)

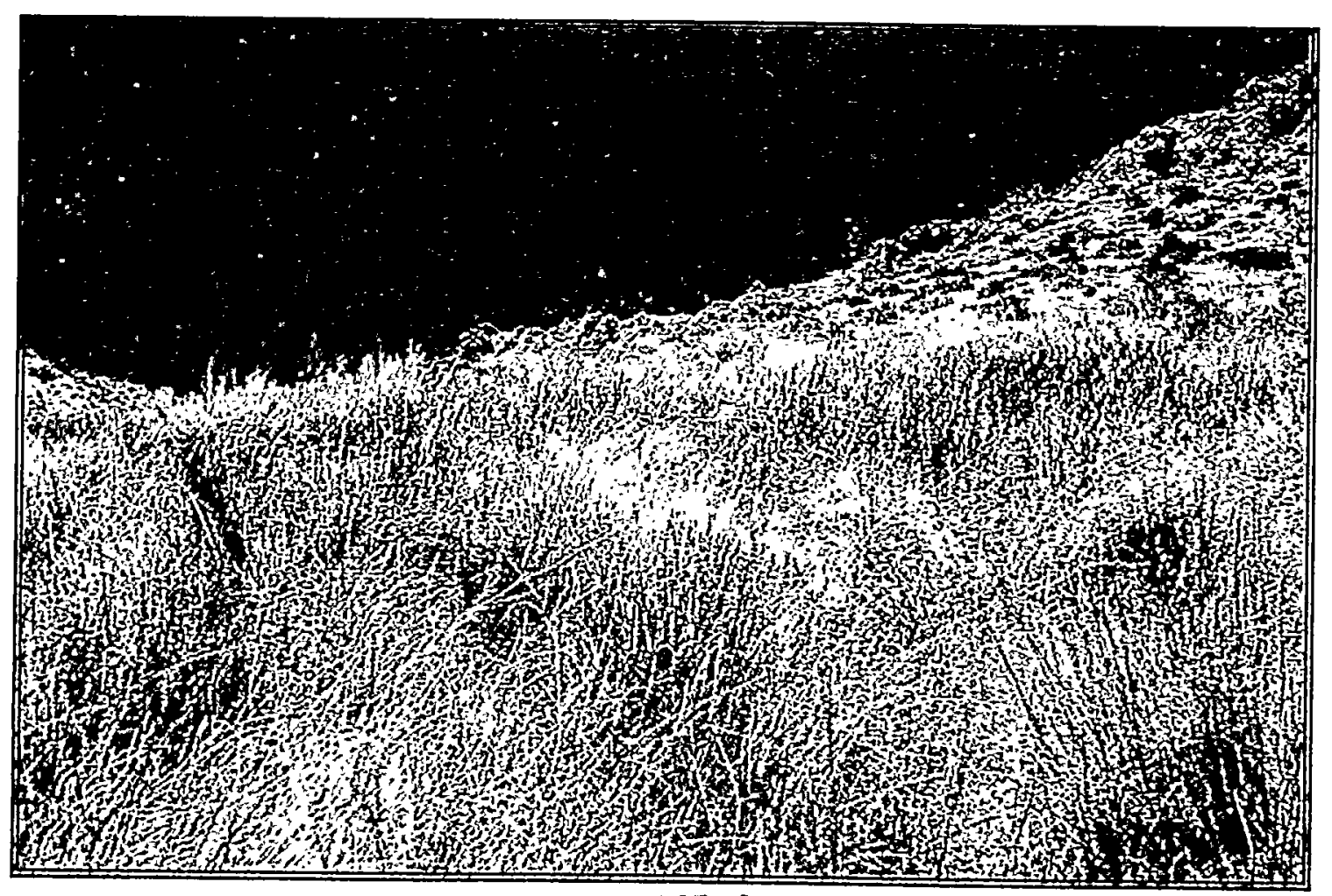

Photo 4-46 Hillside meadow at Topopah Spring looking north on June 20, 1996 (WS339-18.TIF) 
Table 4-18 Topopah Spring wetland vegetation as surveyed on June 20, 1996

\section{Habitat: Cave Pool}

\begin{tabular}{|c|c|c|c|}
\hline Species & Common Name & Indicator Status $\mathrm{s}^{\mathrm{a}}$ & Absolute $\%$ Cover \\
\hline \multicolumn{4}{|l|}{$\begin{array}{r}\text { Tree Layer: } \\
\text { no species }\end{array}$} \\
\hline \multicolumn{4}{|l|}{$\begin{array}{c}\text { Shrub Layer: } \\
\text { no species }\end{array}$} \\
\hline \multicolumn{4}{|l|}{ Herb Layer: } \\
\hline Artemisia ludoviciana & Louisiana sagewort & FACU & 5 \\
\hline Bromus diandrus & ripgut grass & $\mathrm{NL}$ & 1 \\
\hline Epilobium glaberrimum & smooth willowweed & FACW & 5 \\
\hline Mimulus guttatus & seep monkeyflower & OBL & 10 \\
\hline Polypogon monspeliensis & annual rabbitsfoot grass & FACW+ & 1 \\
\hline Potentilla biennis & biennial cinquefoil & FAC & 2 \\
\hline Pseudognaphalium stramineum & straw falsecudweed & NL & 5 \\
\hline Rumex salicifolius & willow dock & $\mathrm{FAC}^{*}$ & 15 \\
\hline Sisymbrium altissimum & tall tumblemustard & FACU & 1 \\
\hline Veronica anagallis-aquatica & water speedwell & OBL & 20 \\
\hline
\end{tabular}

Percentage of dominant plant species that are OBL, FACW, or FAC indicator status:

100 $\%$.

Dominant plant species are indicated by bold Absolute \% Cover values.

${ }^{\mathrm{a}}$ For Region 8 indicator status codes for plants, see Section 3.2.4.

Hydrophytic vegetation: Yes 
Table 4-19 Topopah Spring wetland vegetation as surveyed on June 20, 1996

\section{Habitat: Hillside Meadow}

\begin{tabular}{|c|c|c|c|}
\hline Species & Common Name & $\begin{array}{l}\text { Indicator } \\
\text { Status }^{2}\end{array}$ & Absolute \% Cover \\
\hline \multicolumn{4}{|l|}{$\begin{array}{l}\text { Tree Layer: } \\
\text { no species }\end{array}$} \\
\hline \multicolumn{4}{|l|}{$\begin{array}{l}\text { Shrub Layer: } \\
\text { no species }\end{array}$} \\
\hline \multicolumn{4}{|l|}{ Herb Layer: } \\
\hline \multicolumn{4}{|l|}{ Agrostis exarata } \\
\hline var. monolepis & monolepis bentgrass & FACW & 5 \\
\hline Artemesia ludoviciana & Louisiana sagewort & FACU & 10 \\
\hline Bromus diandrus & ripgut grass & NL & 2 \\
\hline Carex praegracilis & clustered field sedge & FACW & 5 \\
\hline Castilleja sp. & $\begin{array}{l}\text { unidentified Indian } \\
\text { paintbrush }\end{array}$ & UNKN & 2 \\
\hline Conyza canadensis & Canadian horseweed & NL & 2 \\
\hline Eleocharis parishii & Parish's spikerush & OBL & 5 \\
\hline Epilobium glaberrimum & smooth willowweed & FACW & 2 \\
\hline Erigeron divergens & spreading fleabane & NL & 5 \\
\hline Juncus balticus & Baltic rush & FACW & 27 \\
\hline Juncus saximontanus & Rocky Mountain rush & FACW+ & 10 \\
\hline Lactuca serriola & prickly lettuce & FACU & $\operatorname{Tr}$ \\
\hline Mimulus guttatus & seep monkeyflower & OBL & 2 \\
\hline Poa secunda & Sandberg bluegrass & FACU & 20 \\
\hline Polypogon monspeliensis & annual rabbitsfoot grass & $\mathrm{FACW}+$ & 5 \\
\hline Potentilla biennis & biennial cinquefoil & FAC & 2 \\
\hline Pseudognaphalium & & & \\
\hline stramineum & straw falsecudweed & $\mathrm{NL}$ & 2 \\
\hline
\end{tabular}

Percentage of dominant plant species that are OBL, FACW, or FAC indicator status: $50 \%$. Absolute \% cover due to all hydrophytic species present: $63 \%$.

Dominant plant species are indicated by bold Absolute \% Cover values. $\operatorname{Tr}=$ trace, $<1 \%$ absolute cover.

${ }^{a}$ For Region 8 indicator status codes for plants, see Section 3.2.4.

Hydrophytic vegetation:

*Because the number of dominant hydrophytic species was equal to the number of dominant nonhydrophytic species, an alternative method for determining the presence of hydrophytic vegetation was used (Williams, 1992; see Section 3.2.4).

at both the cave pool area and the hillside meadow. The area of wetland vegetation at Topopah Spring comprised a much larger area of about $200 \mathrm{~m}^{2}\left(2,152 \mathrm{ft}^{2}\right)$ (Table 5-1, Section 5.0). 


\subsubsection{Wetland Hydrology and Water Quality}

Field indicators for wetland hydrology were observed at both the cave pool area and the hillside meadow. Surface water was present at the site on June 20,1996, and the combined area of standing water was estimated to be about $8 \mathrm{~m}^{2}\left(86 \mathrm{ft}^{2}\right)$. Flow rates at Topopah Spring, measured from the existing pipe, were very low $(0.14 \ell / \mathrm{min}[0.04$ $\mathrm{gal} / \mathrm{min}]$ ) (Table 5-1, Section 5.0). Water flow was widely distributed on the hillside meadow and was not measured. Water quality measurements were taken in the spring pool in June and September 1996. Data are presented in Table 5-2 (Section 5.0).

\subsubsection{Hydric Soils}

Field indicators of hydric soils were observed at both the cave pool area and the hillside meadow and consisted of saturated or inundated soils which appeared to be inundated for seven days or longer during the plant growing season, indicating the presence of hydric soil. Two soil pits were dug to examine soils for field indicators for hydric soils. Mottling was not observed in the soil exposed from these soil pits.

\subsubsection{Determination of Jurisdictional Status}

Both the cave pool area and the hillside meadow at Topopah Spring would probably be considered jurisdictional wetlands because they had field indicators for all three required parameters: hydrophytic vegetation, wetland hydrology, and hydric soils.

\subsubsection{Wildlife Use}

Wildlife commonly using this spring include coyote, mountain lion, mule deer, raptors, and passerine birds. Upland game birds are common including chukar, Gambel's quail, and mourning dove. Extensive use of this spring is made by chukar in the summer. Biologists have observed hundreds of these birds around the cave pool during numerous visits.

\subsubsection{Tub Spring}

\subsubsection{Site Description and Historical Use}

Tub Spring is located in a wash on a southeast-facing slope on the east side of Oak Spring Butte, north of Yucca Flat (Figure 4-17, Photo 4-47). Access to water at Tub Spring was developed by local mining operations located about $1.6 \mathrm{~km}(1 \mathrm{mi})$ southwest of the spring (Giles, 1976). After the spring was developed, it was probably used to water cattle that grazed in the region before 1950 . A tunnel 0.6 to $0.9 \mathrm{~m}$ ( 2 to $3 \mathrm{ft}$ ) wide was excavated

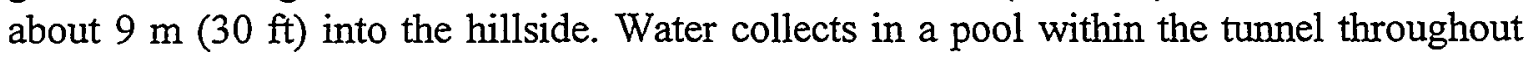
the year behind a small earthen dam at the tunnel entrance. The depth of the water is

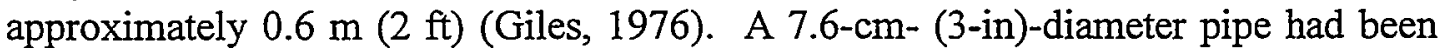
installed from the tunnel down slope about $60 \mathrm{~m}(197 \mathrm{ft})$ to a large metal watering tank. In 1975 , the spring and pipeline system was renovated after a rock slide plugged the pipeline (Smith et al., 1978). Additionally, a wire screen was placed over the pipe entrance to prevent recurrence of the blockage. The original pipeline and watering tank 


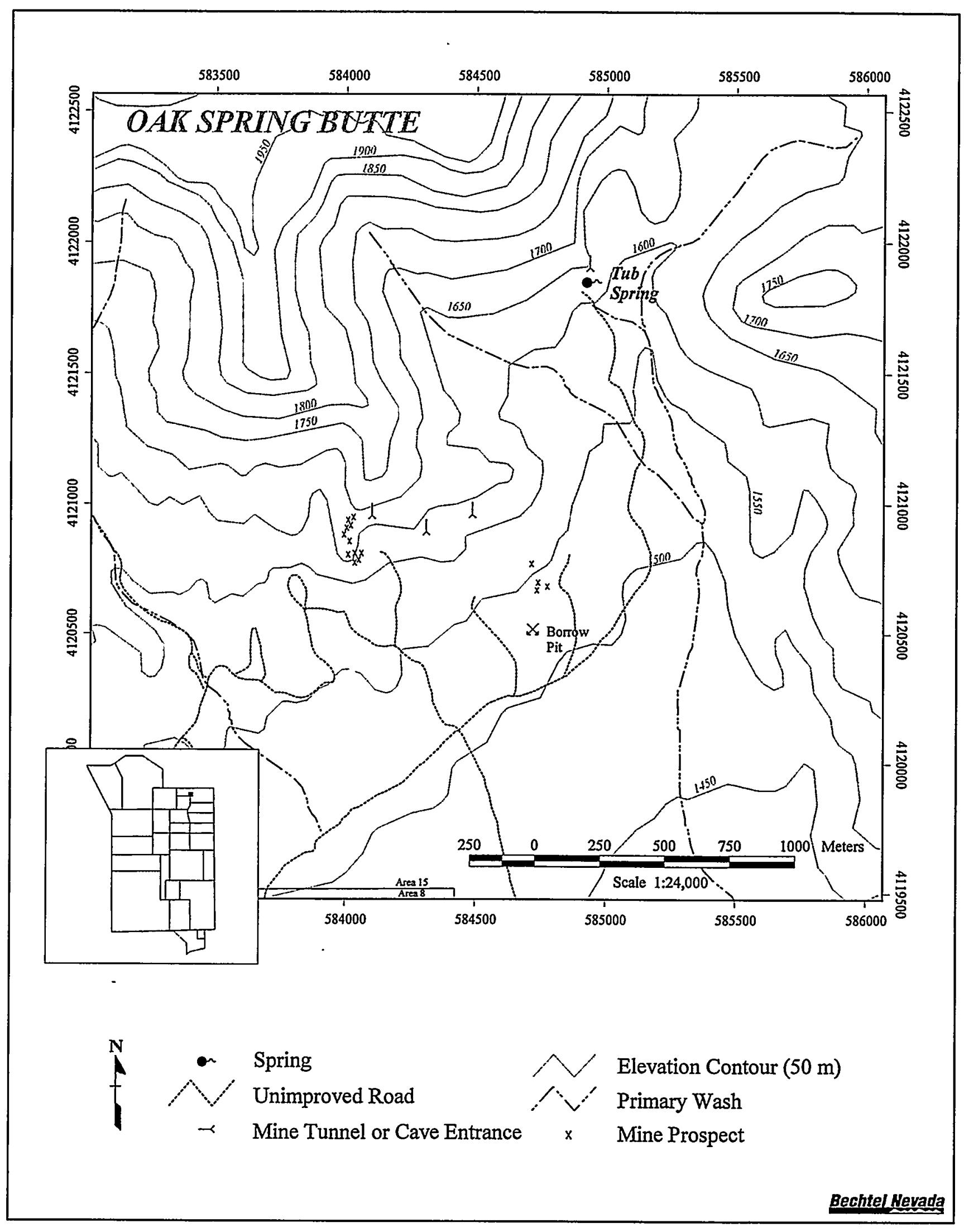

Figure 4-17 Location of Tub Spring 


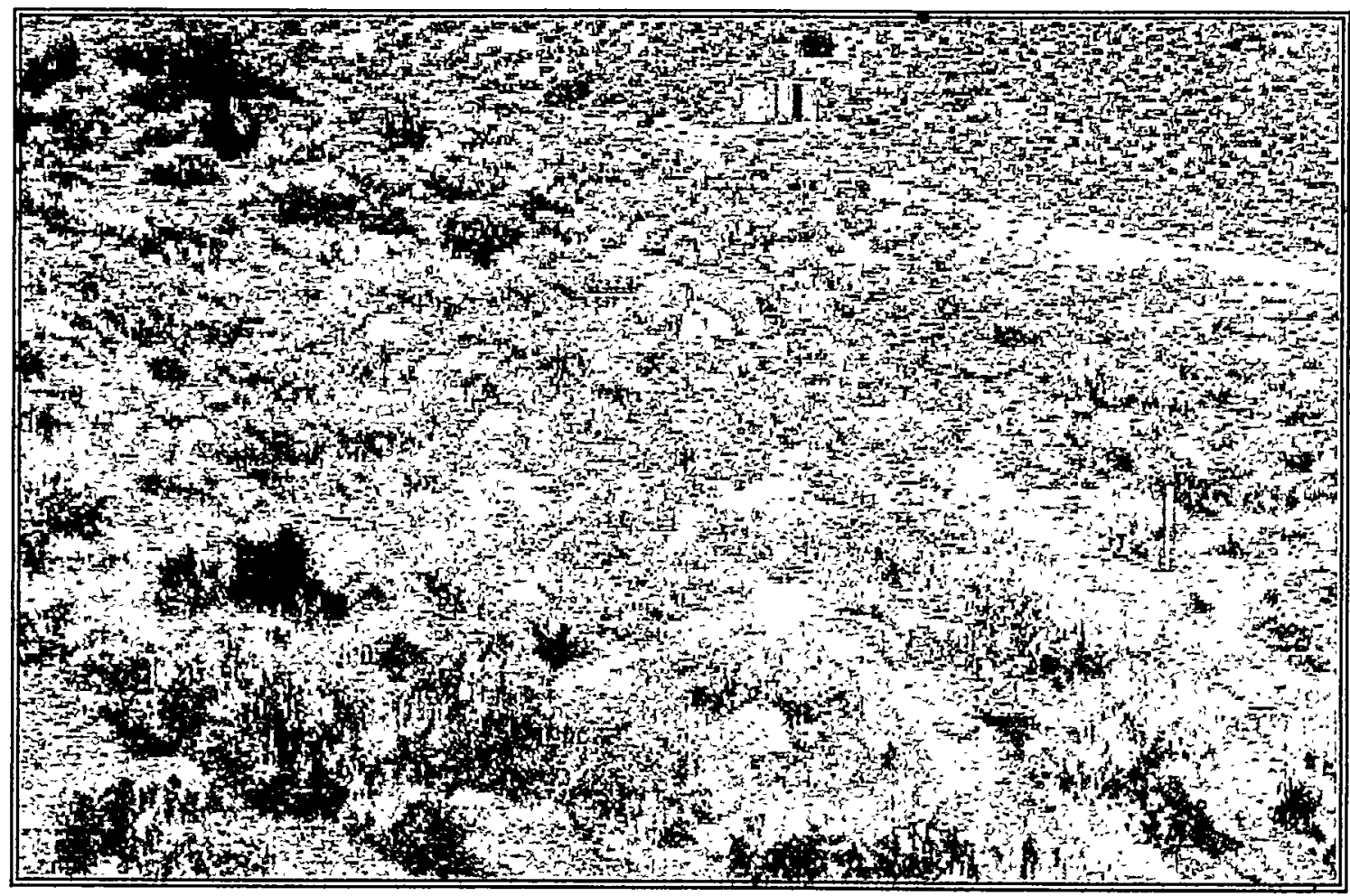

Photo 4-47 Habitat at Tub Spring looking northwest on November 10, 1988 (WS046-20.TIF)

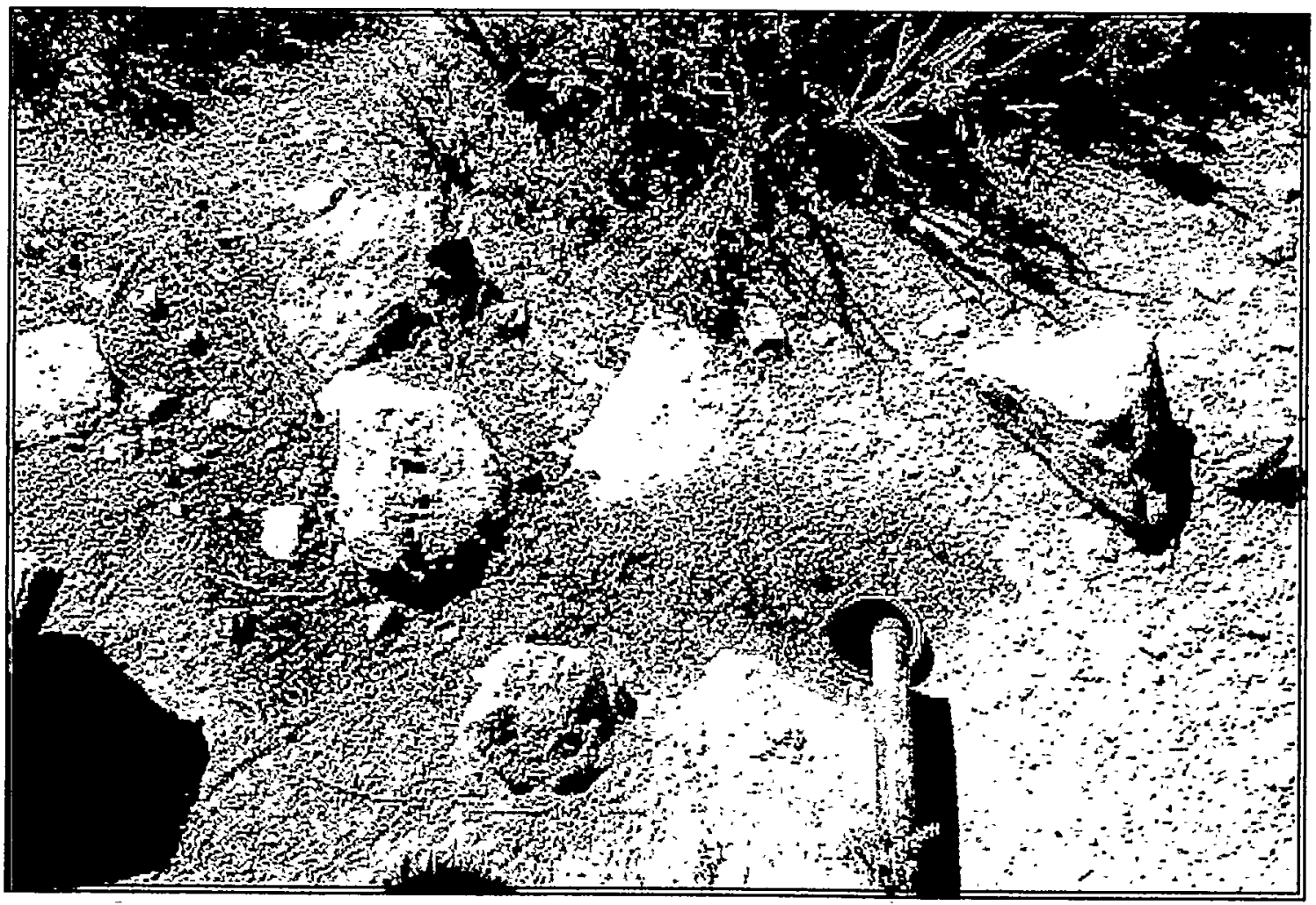

Photo 4-48 Vegetation around Tub Spring on August 24, 1996 (WS046-20.TIF) 
were reused. In the $1980 \mathrm{~s}$, biologists conducting wildlife surveys at the site observed that the pipe was broken and that no water was flowing into the metal watering tank. Some time in the early $1990 \mathrm{~s}$, a $3.8-\ell$ (1-gal) tin can was installed in the ground under the broken end of the pipe which was about $10 \mathrm{~m}(33 \mathrm{ft})$ upslope from the watering tank. Water currently runs through the pipe, fills the tin can, and overflows onto the ground forming a wetted area of about $1 \mathrm{~m}^{2}\left(11 \mathrm{ft}^{2}\right)$ (Photo $\left.4-48\right)$.

\subsubsection{Hydrophytic Vegetation}

Only two plant species, skunkbush sumac, and an unidentified grass, were observed growing in a small moist area around the tin can (Table 4-20). Upland vegetation near this area includes desert needlegrass (Achnatherum speciosum), fourwing saltbush, big sagebrush, foxtail brome, cheatgrass, blackbrush, mormon tea, Nevada jointfir, Cooper's heathgoldenrod, rubber rabbitbrush, and Stansbury cliffrose. Hydrophytic vegetation was absent from this site and at the cave pool.

Table 4-20 Tub Spring wetland vegetation as surveyed on November 7, 1996

\begin{tabular}{|c|c|c|c|}
\hline Species & Common Name & Indicator Status ${ }^{2}$ & Absolute \% Cover \\
\hline \multicolumn{4}{|l|}{$\begin{array}{l}\text { Tree Layer: } \\
\text { no species }\end{array}$} \\
\hline $\begin{array}{l}\text { Shrub Layer: } \\
\text { Rhus trilobata }\end{array}$ & skunkbush sumac & $\mathrm{NI}$ & 10 \\
\hline $\begin{array}{l}\text { Herb Layer: } \\
\text { unidentified grass }\end{array}$ & & UNKN & 1 \\
\hline
\end{tabular}

Hydrophytic vegetation: No

\subsubsection{Wetland Hydrology and Water Quality}

Field indicators of wetland hydrology were limited to the cave pool and the saturated area around the tin can where surface water was present. It is likely that the area around the tin can would be dry if it had not been developed by the recent activities of man. Flow rate measured from the broken pipe on September 20, 1996 was $0.1 \mathrm{l} / \mathrm{min}(0.03 \mathrm{gal} / \mathrm{min})$ (Table 5-1, Section 5.0). Water quality measurements were taken in the guzzler can in June and September 1996 and are presented in Table 5-2 (Section 5.0). 


\subsubsection{Hydric Soils}

Field indicators of hydric soils were observed at the cave pool and around the tin can. Soils in these areas appeared to have been saturated for more than seven days during the growing season, indicating the presence of hydric soil. However, because the soils around the can are dependent on water being delivered by the pipe, this area is considered artificially wet. No soil pits were dug due to the small size of the area and the evidence of prior disturbance. Soils appeared to be poorly developed in undisturbed areas around the site.

\subsubsection{Determination of Jurisdictional Status}

No area at Tub Spring would be considered a jurisdictional wetland because all areas lacked field indicators for hydrophytic vegetation. Although the cave pool would not be considered a jurisdictional wetland, it may be considered waters of the United States.

\subsubsection{Wildlife Use}

Chukar, coyotes, Gambel's quail, mourning doves, mountain lions, mule deer, and passerine birds drink water at the site.

\subsubsection{Tupapa Seep}

\subsubsection{Site Description and Historical Use}

This site was identified as "Tupapa Seep Spring" on the Camp Desert Rock USGS 7.5Minute Series quadrangle map (1961). No spring could be found at the site and it was renamed for this report as "Tupapa Seep." It is located in a wash in a remote area about $1 \mathrm{~km}(0.6 \mathrm{mi})$ southeast of Hampel Hill and $3.2 \mathrm{~km}(2 \mathrm{mi})$ southwest of Frenchman Flat (Figure 4-18). The site appears to be unaltered by man (Photo 4-49), and no historical accounts of human activity at the spring were found.

\subsubsection{Hydrophytic Vegetation}

A vegetation survey from an observation point located within the wash was conducted at Tupapa Seep on November 7, 1996 (Photo 4-50). From the observation point only one dominant species was classified as a hydrophytic plant, foxtail barley (Hordeum jubatum). Cheatgrass, an upland grass, was the only other dominant species observed in the sample area (Table 4-21). Other plants in the sample area included: shadscale saltbush, rubber rabbitbrush, and Mexican bladdersage. Based on the weak showing of hydrophytic species at this site, it was concluded that the criteria for hydrophytic vegetation were lacking.

\subsubsection{Wetland Hydrology and Water Quality}

Field indicators of wetland hydrology were lacking at this site. No evidence of surface water or saturated soils was detected during visits to Tupapa Seep in September and November 1996. This seep is probably seasonally intermittent in flow and appears to 


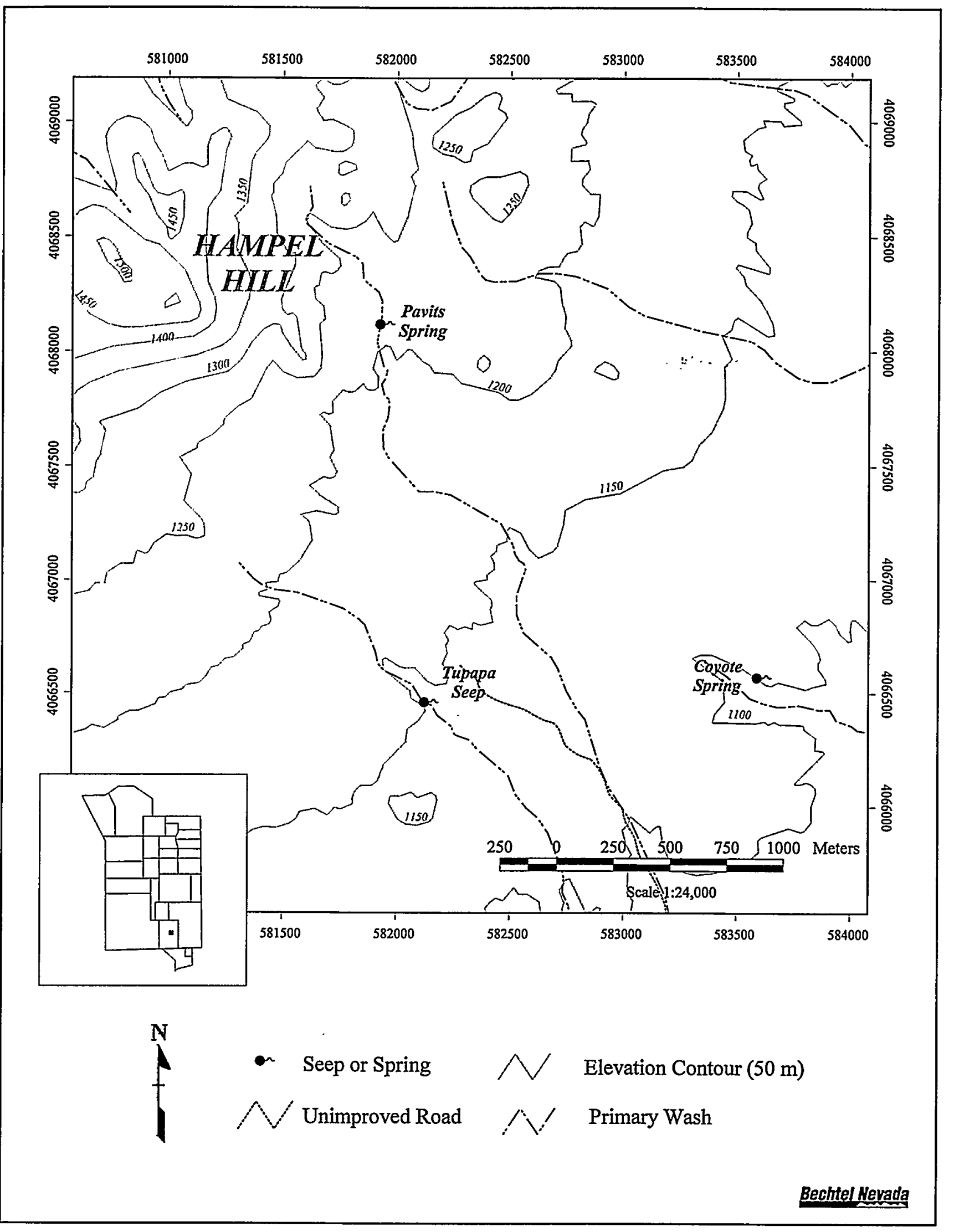

Figure 4-18 Location of Tupapa Seep 


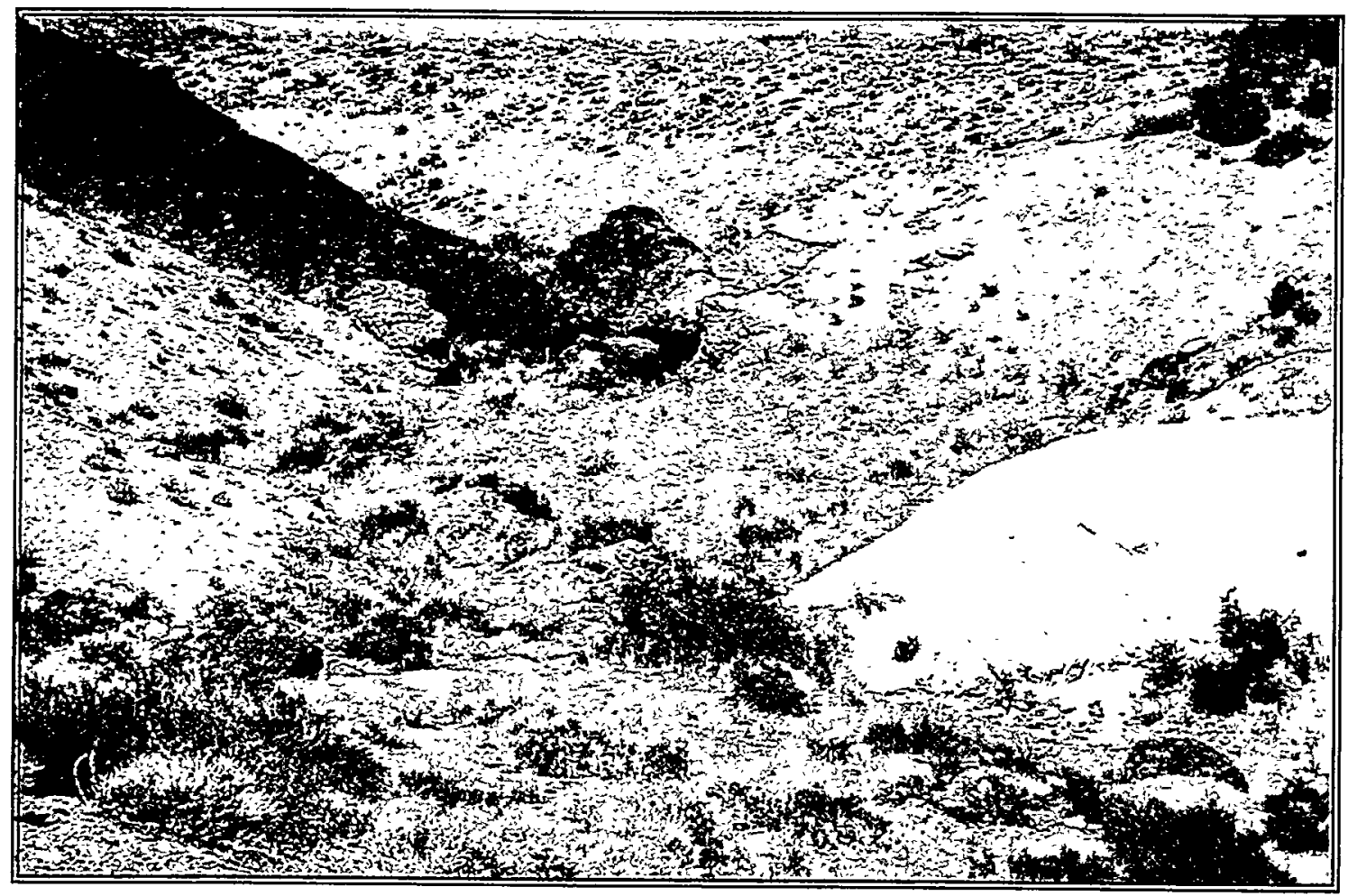

Photo 4-49 Habitat around Tupapa Seep looking north on September 4, 1996 (WS505-01.TIF)

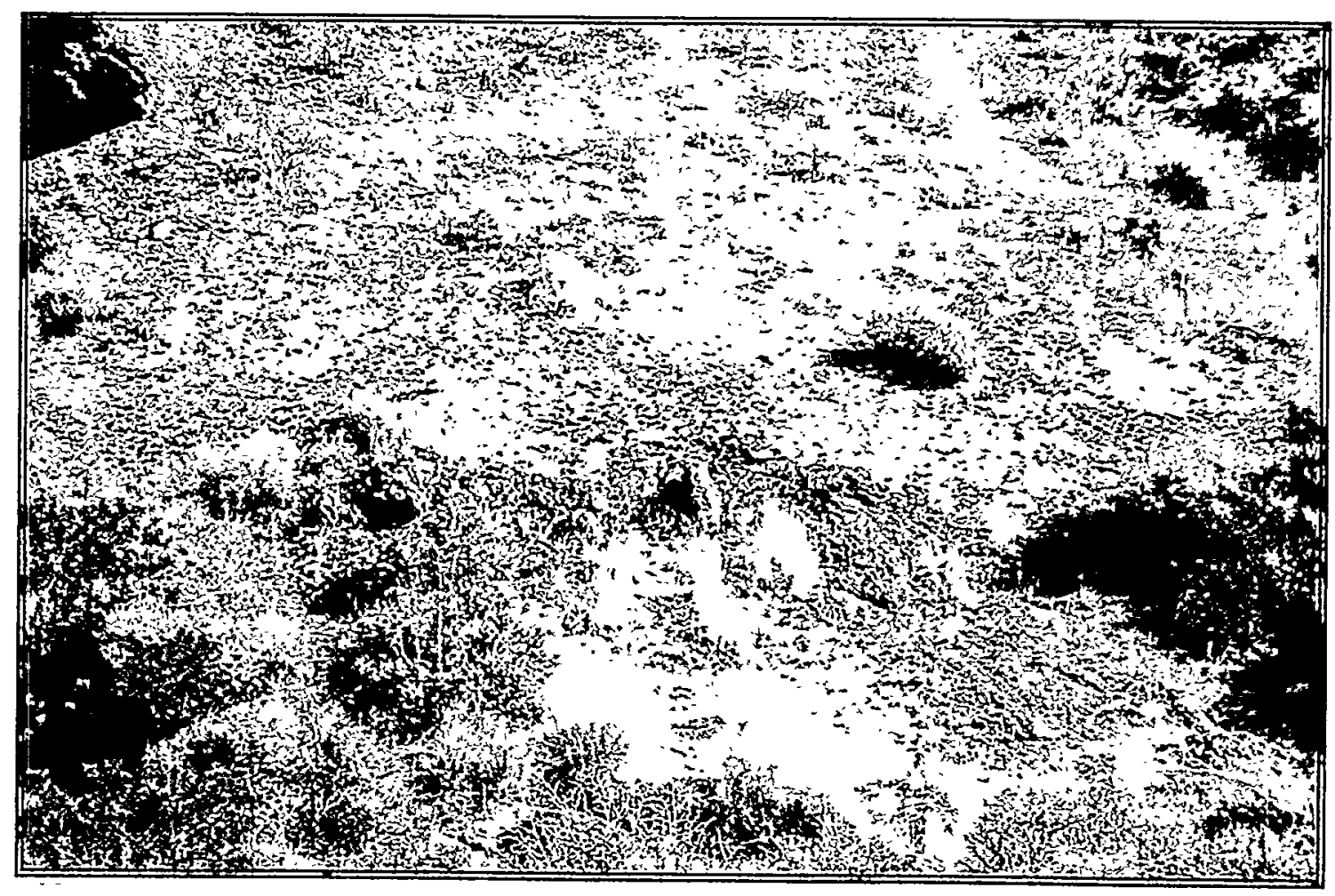

Photo 4-50 Closeup of vegetation at Tupapa Seep looking east on November 4, 1996 (WS505-03.TIF) 


\begin{tabular}{llll}
$\begin{array}{l}\text { Habitat: Wash } \\
\text { Species }\end{array}$ & Common Name & Indicator Status & Absolute \% Cover \\
\hline $\begin{array}{l}\text { Tree Layer: } \\
\text { no species }\end{array}$ & & & \\
Shrub Layer: & & & \\
$\quad$ Atriplex confertifolia & shadscale saltbush & $\mathrm{NL}$ & 2 \\
Ericameria nauseosa & rubber rabbitbrush & $\mathrm{NL}$ & 2 \\
Salazaria mexicana & Mexican bladdersage & $\mathrm{NL}$ & 2 \\
Herb Layer: & & & \\
Bromus tectorum & cheatgrass & $\mathrm{NL}$ & $\mathbf{2 0}$ \\
Hordeum jubatum & foxtail barley & FAC* & $\mathbf{6 0}$ \\
\hline
\end{tabular}

Percentage of dominant plant species that are OBL, FACW, or FAC indicator status: $50 \%$.

Dominant plant species are indicated by bold Absolute \% Cover values.

${ }^{a}$ For Region 8 indicator status codes for plants, see Section 3.2.4.

Hydrophytic vegetation: No

remain dry in low rainfall years. Knowledge of seasonal availability of water at this site is lacking because of limited prior study. No water quality measurements were taken at this site.

\subsubsection{Hydric Soils}

No field indicators for hydric soils were observed at this site in 1996. Soils appeared dry at the time of the survey and no soil pits were dug. Soils in the area did appear to be dark with a low chroma value.

\subsubsection{Determination of Jurisdictional Status}

This site would probably not qualify as a jurisdictional wetland based on a lack of field indicators for all three required parameters: hydrophytic vegetation, wetland hydrology, and hydric soils. Some seepage may occur in wet years and sustain plant species that are occasionally found in wetlands. However, during dry years few wetland species persist. The lack of archaeological and historical features at the site also suggests that this site did not provide a dependable supply of water.

\subsubsection{Wildlife Use}

Because of limited study, little is known about wildlife use of the area; however, coyote scat and a common raven were observed near the seep area. 


\subsubsection{Twin Spring}

\subsubsection{Site Description and Historical Use}

This site is shown as an unnamed spring on the Topopah Spring USGS 7.5-Minute Series quadrangle map (1961), but has been referred to in the literature as "Twin Springs" (Stoffle et al., 1990b). For purposes of this report, the site is referred to as "Twin Spring" because only one spring with surface inundation was apparent at the site. Twin Spring is located in Fortymile Canyon about $91 \mathrm{~m}$ (300 ft) above the canyon floor on a steep (40 percent) west-facing slope (Figure 4-19, Photo 4-51). The area is believed to have been used as a trappers' camp by Native Americans until recent times (Stoffle et al., 1990b). Numerous prehistoric artifacts exist near the spring and on the slope below the spring, including a petroglyph boulder, stone chips, grinding slabs, rock rings, rock coyote trap, and rock weights to hold nets and trap wildlife. Rock shelters also exist on the opposite side of the canyon (Stoffle et al., 1990b).

Much Euroamerican activity has been reported in Fortymile Canyon including mining, prospecting, and travel. During the period of 1870 to 1900 , there were freight and mail routes (i.e., Emigrant Trail) that passed through Fortymile Canyon, with relay stations at Whiterock Spring, Tippipah Spring, and Fortymile Canyon (Stoffle et al., 1990a). The Twin Spring site may have been the location of the relay station, although direct evidence for this is lacking (Henton and Pippin, 1988). A lead-silver mine was also worked in the Fortymile Canyon area during the 1880s and was rediscovered and worked again in 1905 (Stoffle et al., 1990a).

The most conspicuous human impact at Twin Spring is a man-made cave dug about $18 \mathrm{~m}$ (98 ft) into the hillside and located about $30 \mathrm{~m}(98 \mathrm{ft}$ ) north of the existing spring. This cave occurs at the same elevation as the existing spring and could be the original site of the second spring. The tailings from this cave were leveled off and a rock wall or foundation was built on it. A cave-in was noted about $3 \mathrm{~m} \mathrm{(10} \mathrm{ft)} \mathrm{inside} \mathrm{the} \mathrm{entrance.}$ Historic artifacts found at the cave include round nails, lumber, and a condensed milk can (Henton and Pippin, 1988). The purpose of the cave is unclear, but Henton and Pippin (1988) suggest it was not dug for mining purposes but as an improvement to the second spring.

Water was piped from the existing spring to the bottom of the wash, a distance of about $300 \mathrm{~m}(984 \mathrm{ft})$, as shown by the presence of metal pipes and a large cement water tank.

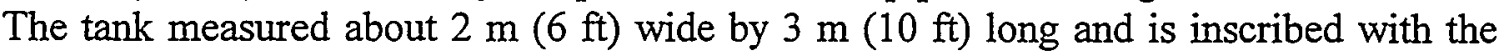
date "1921" (Henton and Pippin, 1988).

\subsubsection{Hydrophytic Vegetation}

A wetlands vegetation survey was conducted on December 12, 1996, from an observation point located at the base of a rock ledge where water flows out and forms a small pool (referred to as the wash slope area). One hundred percent of the dominant plants in this area were hydrophytic species indicating that hydrophytic vegetation was present at Twin Spring (Table 4-22). T. domingensis was the only dominant wetland species growing in a small, inundated area within the sample area. Other wetland species which accounted for 


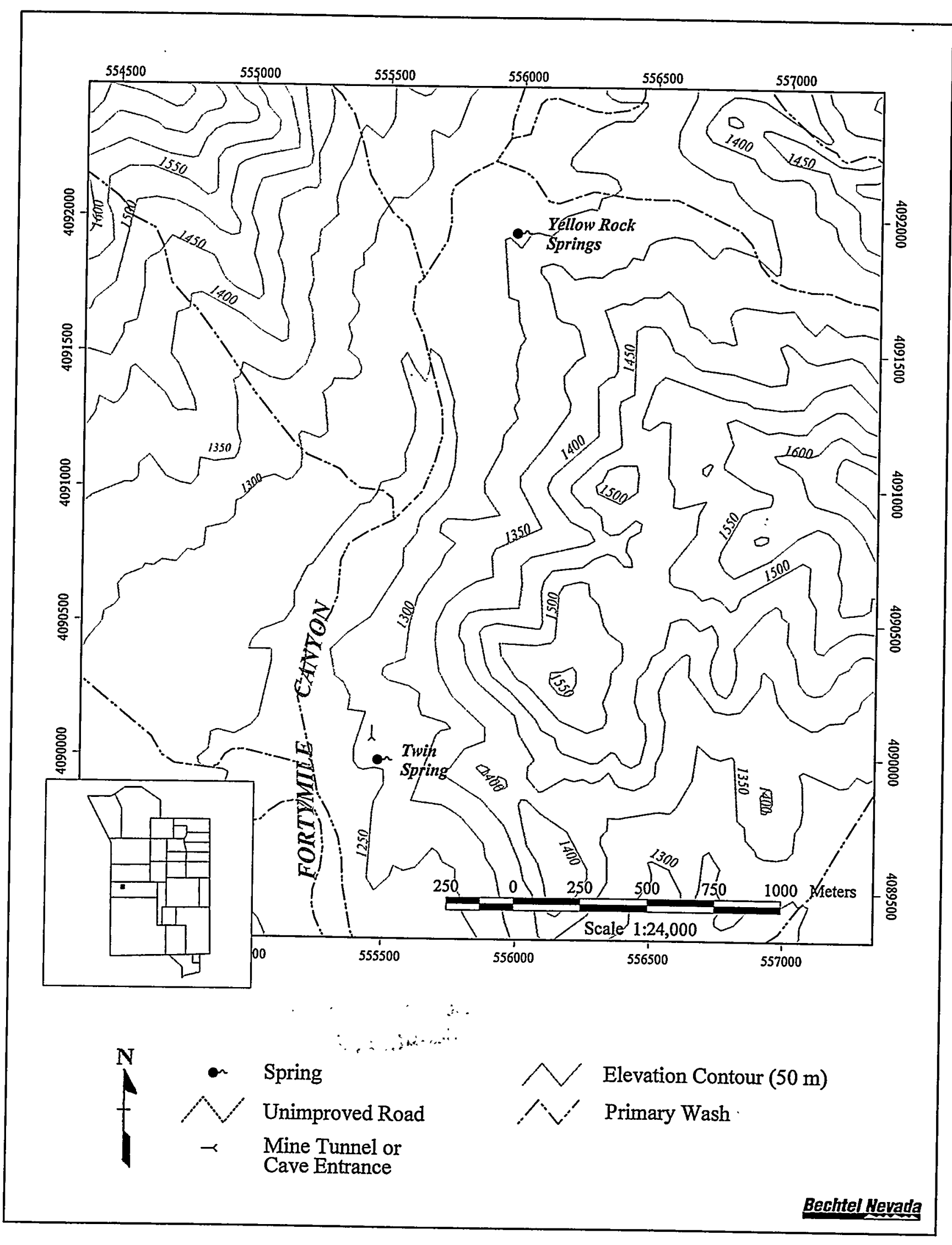

Figure 4-19 Location of Twin Spring 


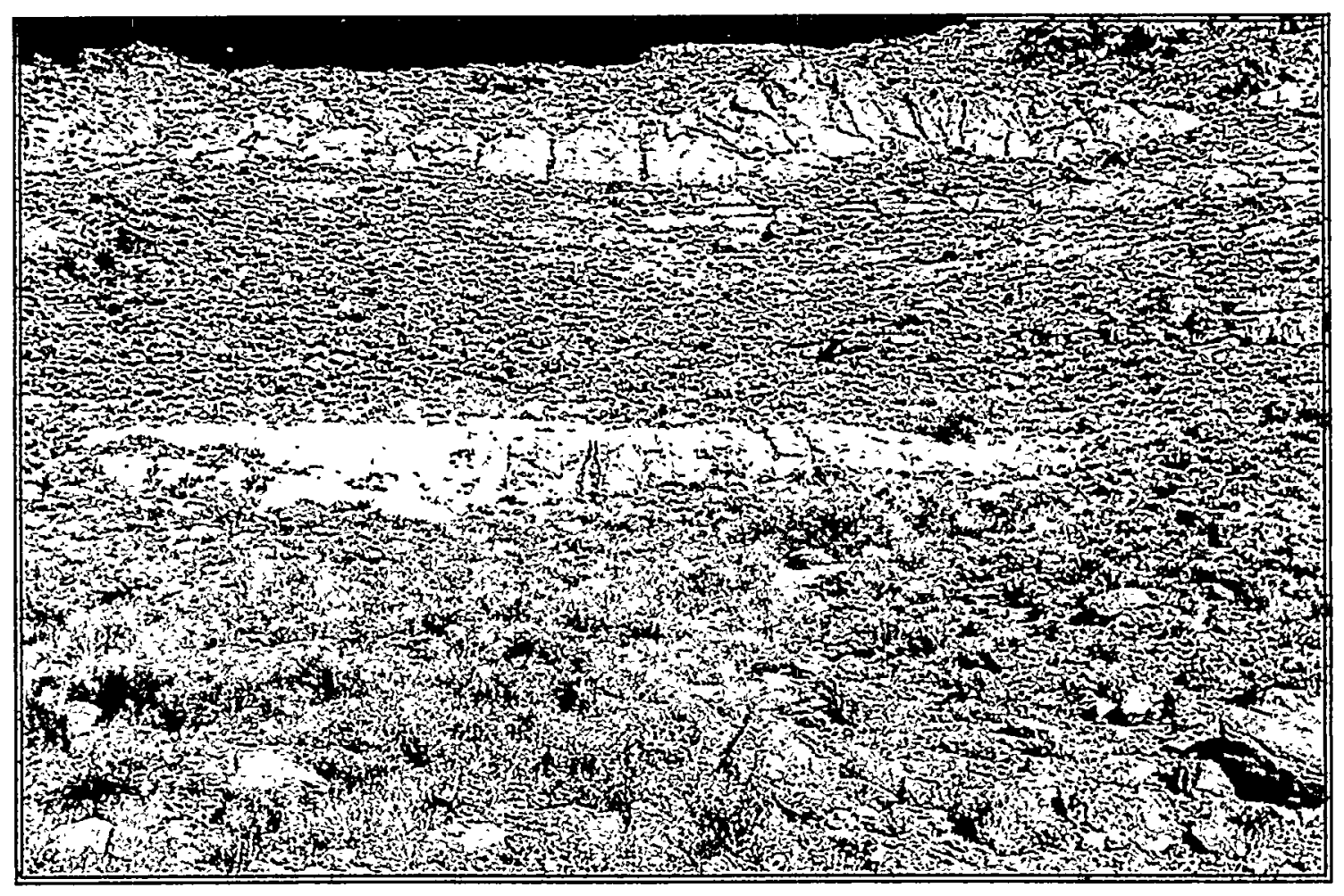

Photo 4-51 Habitat around Twin Spring looking east on January 8, 1997 (WS347-19.TIF)

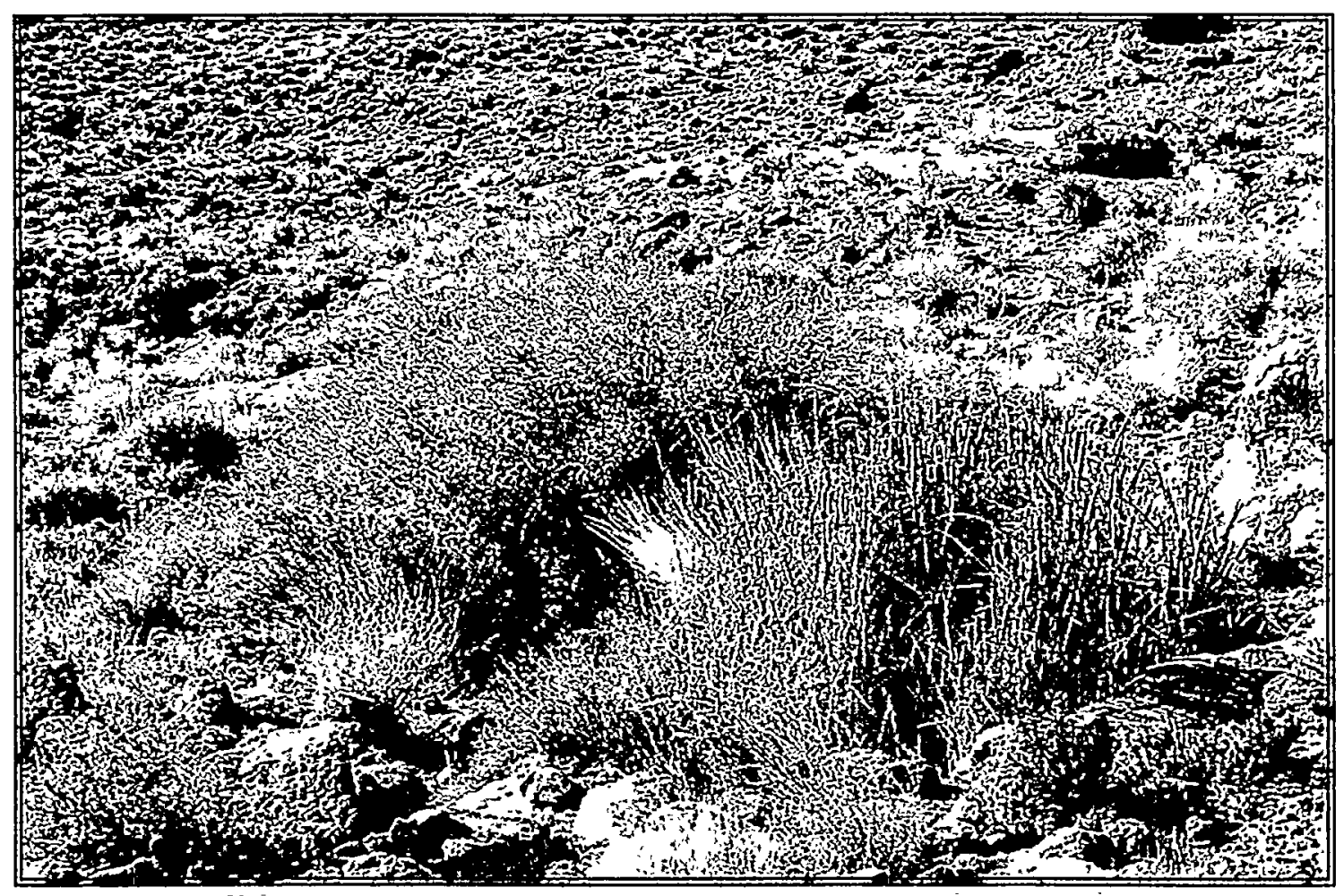

Photo 4-52 Wetland vegetation at Twin Spring looking north on January 8, 1997 (WS347-22.TLF) 


\section{Habitat: Wash Slope Area}

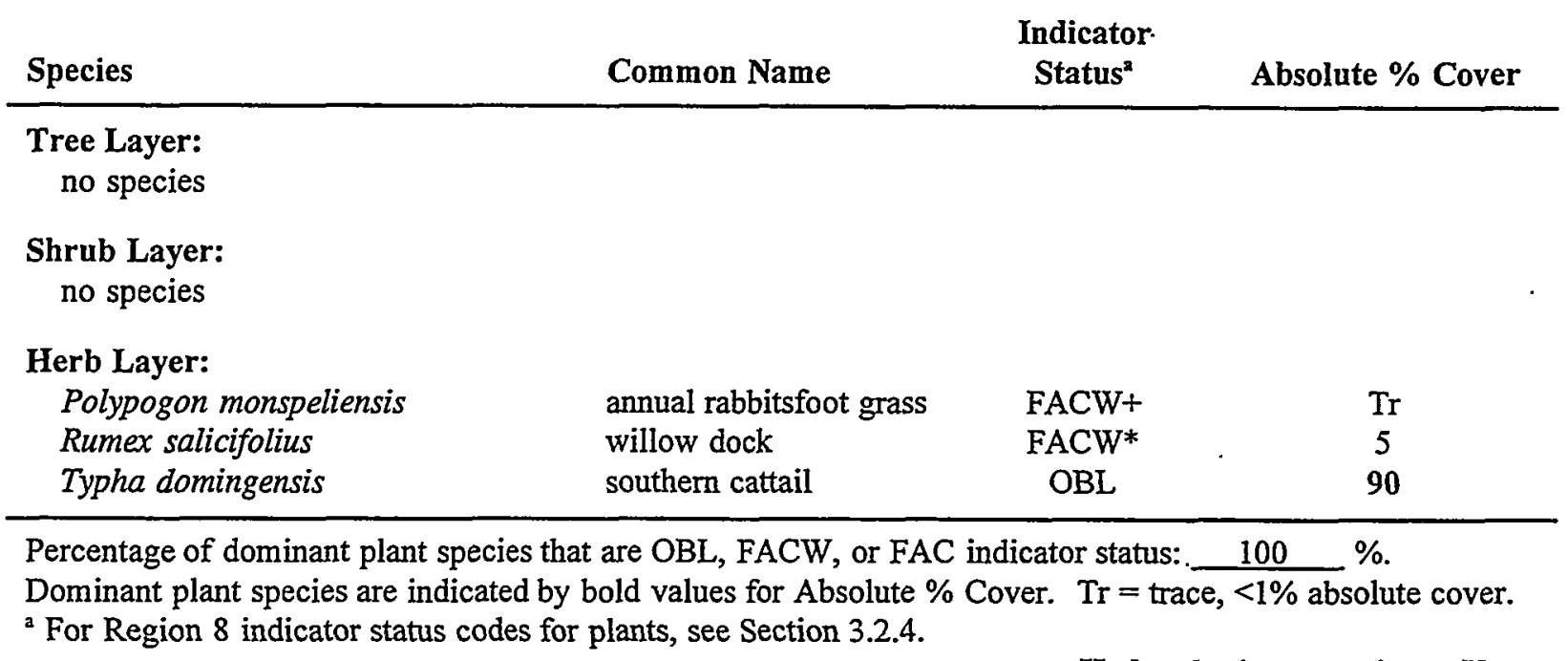

Hydrophytic vegetation: Yes

less than 6 percent of the absolute cover at the site were willow dock and annual rabbitsfoot grass The wetland area was limited to about $27 \mathrm{~m}^{2}\left(291 \mathrm{ft}^{2}\right)$ (Table 5-1, Section 5.0). Plants growing in a transitional area on the edge of the inundated area included wormwood, Louisiana sagewort, and skunkbush sumac. The other wet area at Twin Spring was a man-made cave (see Section 4.2.19.3 below) which did not contain hydrophytic vegetation and represented an atypical situation because of prior disturbance. Vegetation in the upland area surrounding the spring included fourwing saltbush, cheatgrass, green rabbitbrush, Virgin River brittlebush (Encelia virginensis), Nevada jointfir, mormon tea, eastern Mojave buckwheat, spiny hopsage (Grayia spinosa), and Mexican bladdersage.

\subsubsection{Wetland Hydrology and Water Quality}

This site has been referred to as "Twin Springs" (Stoffle et al., 1990b), which suggests that there were two spring sources at the site. However, only one spring with surface inundation is apparent at the site. Currently, water flows out from the base of a rock ledge and forms a small pool which measures about $2 \mathrm{~m}^{2}\left(22 \mathrm{ft}^{2}\right)$ (Photo 4-52). This area is referred to as the wash slope area. The maximum depth of the pool within the wash slope area was about $10 \mathrm{~cm}$ (4 in) in December 1996. Minimal surface flow occurred down the slope from the pool, but this was not measured. Flow was visible below the wetland area for about $4 \mathrm{~m}(13 \mathrm{ft})$ in a steep rocky wash. Water quality measurements were taken in January 1997, and the data are presented in Table 5-2 (Section 5.0).

The man-made cave which occurs at the same elevation as the existing spring could be the original site of the second spring. The cave-in here could have stopped water flow from 
the cave, and the tailings removed from the cave could also be concealing the spring discharge area. Saturated soils occurred on the floor of this cave.

\subsubsection{Hydric Soils}

Field indicators for hydric soils were present at Twin Spring and were confined to the wash slope area and to the man-made cave. Soils in these areas appeared to have been saturated for seven days or more during the plant growing season, indicating the presence of hydric soil. The soils in the cave area may be considered atypical because of disturbance by man.

\subsubsection{Determination of Jurisdictional Status}

The wash slope area at Twin Spring would probably qualify as a jurisdictional wetland because it has field indicators of all three wetland parameters: hydrophytic vegetation, wetland hydrology, and hydric soils. The man-made cave area did not support hydrophytic vegetation and probably would not be considered a jurisdictional wetland.

\subsubsection{Wildlife Use}

Use of the spring by wild burros (Equus asinus) was evidenced by the presence of scat near the cave. Coyote and mule deer scat also occurred around the spring. Deer remains were found at the spring, indicating that mountain lions may also frequent the site.

\subsubsection{Wahmonie Seep 1}

\subsubsection{Site Description and Historical Use}

Wahmonie Seep 1 is located in a wash bottom north of Skull Mountain about, $1 \mathrm{~km}(0.6$ mi) south of Cane Spring Road (Figure 4-20). A mine shaft and some prospect markers (piles of rock) are located near the seep. This seep shows no impacts from man, and is not marked on any USGS topographic map. This wetland has not been previously studied because no current or historical references concerning this seep were found.

\subsubsection{Hydrophytic Vegetation}

The slope of the wash is gentle ( 5 percent) and wetland boundaries are easily distinguished from the boundaries of the surrounding upland plant community (Photo 4-53). A vegetation survey was conducted at the bottom of the wash channel on June 20, 1996. The dominant wetland species observed from the observation point were Emory's baccharis (Baccharis emoryi), Baltic rush, and water speedwell. Saltcedar occurred in the wash about $30 \mathrm{~m}$ (98 ft) downstream from the observation point. Unidentified mosses were common in the wash channel. Sixty percent of the dominant species at the observation point were wetland species indicating the presence of hydrophytic vegetation at the site (Table 4-23). The total area of the wetland as defined by hydrophytic vegetation within the wash channel is approximately $250 \mathrm{~m}^{2}\left(2,690 \mathrm{ft}^{2}\right.$ ) (Table 5-1, Section 5.0). Plant species in the adjacent upland included blackbrush, Cooper's heathgoldenrod, rubber rabbitbrush, basin wildrye, and Mexican bladdersage. 


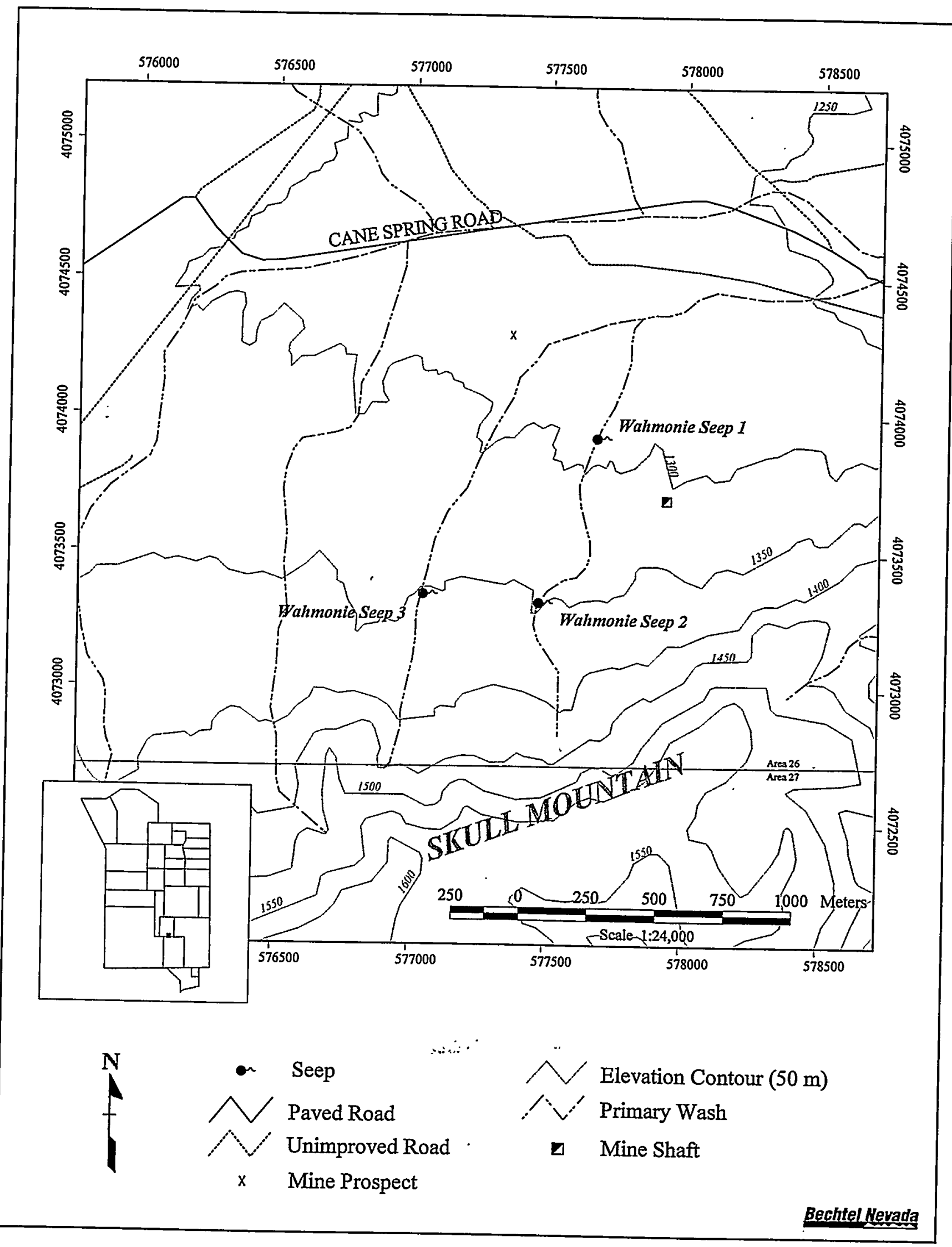

Figure 4-20 Location of Wahmonie Seep 1 


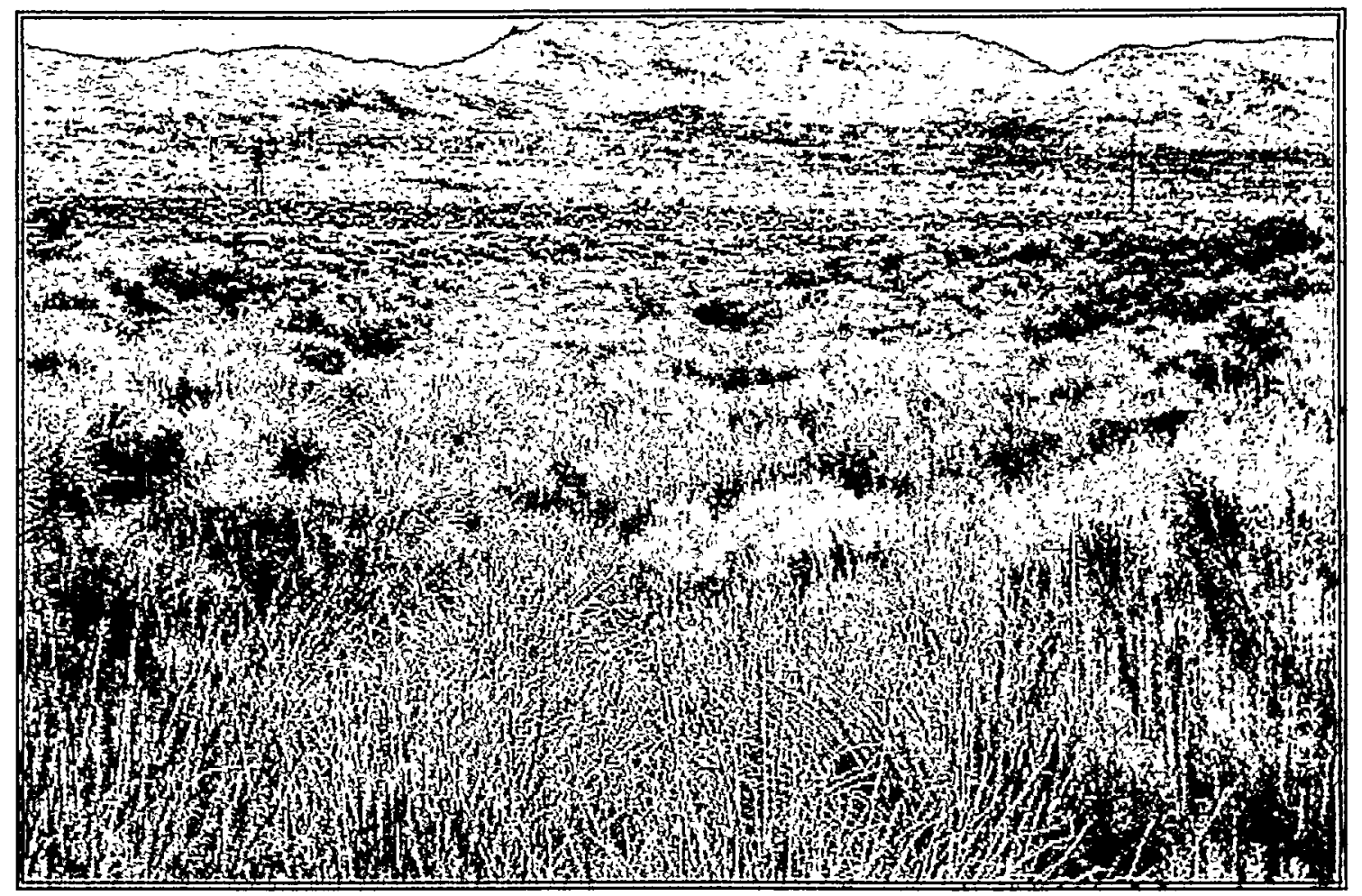

Photo 4-53 Wahmonie Seep 1 looking north on June 20, 1996 (WS339-09.TIF)

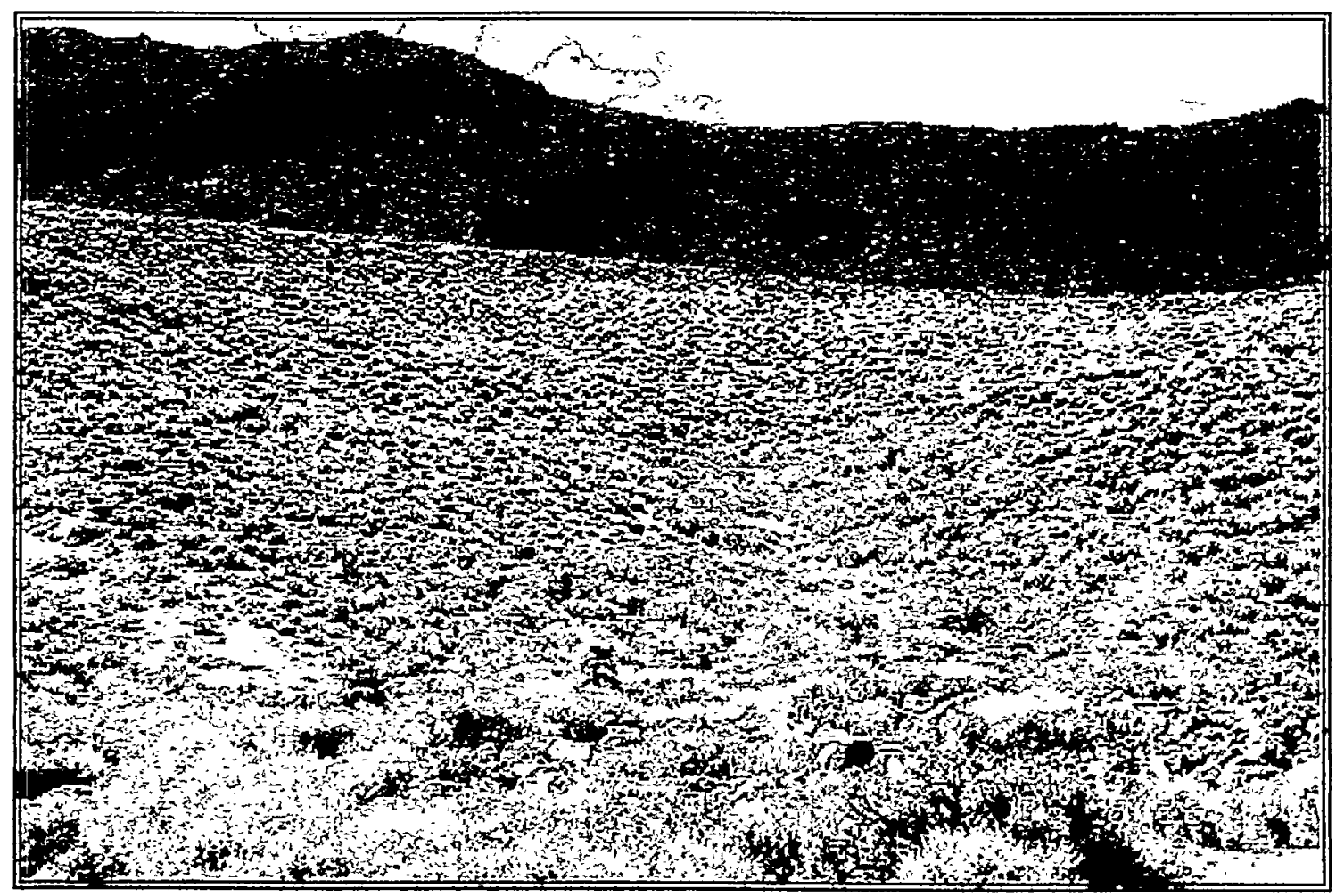

Photo 4-54 Wahmonie Seep 2 looking south on June 20, 1996 (WS339-12.TIF) 


\section{Habitat: Wash Channel}

\begin{tabular}{lllc} 
Species & Common Name & Indicator Status $^{\mathbf{a}}$ & $\begin{array}{c}\text { Absolute \% } \\
\text { Cover }\end{array}$ \\
\hline $\begin{array}{l}\text { Tree Layer: } \\
\text { no species }\end{array}$ & & & \\
Shrub Layer: & & & \\
Baccharis emoryi & Emory's baccharis & FACW & 40 \\
Ericameria nauseosa & rubber rabbitbrush & NL & 10 \\
Herb Layer: & & & \\
Artemisia ludoviciana & Louisiana sagewort & FACU & 1 \\
Juncus balticus & Baltic rush & FACW & $\mathbf{3 0}$ \\
Leymus cinereus & basin wildrye & FACU & $\mathbf{1 5}$ \\
Mimulus guttatus & seep monkeyflower & OBL & 2 \\
Polypogon monspeliensis & annual rabbitsfoot grass & FACW+ & 1 \\
Veronica anagallis-aquatica & water speedwell & OBL & $\mathbf{1 0}$ \\
unidentified moss & & UNKN & 1 \\
\hline
\end{tabular}

Percentage of dominant plant species that are $\mathrm{OBL}, \mathrm{FACW}$, or FAC indicator status: Dominant plant species are indicated by bold Absolute \% Cover values.

${ }^{3}$ For Region 8 indicator status codes for plants, see Section 3.2.4.

Hydrophytic vegetation:

\subsubsection{Wetland Hydrology and Water Quality}

Field indicators of wetland hydrology were restricted to an area characterized by saturated soils in a narrow corridor along the wash channel. Surface water existed at this site in one isolated pool at the time of the survey. This pool was only $5 \mathrm{~m}^{2}\left(54 \mathrm{ft}^{2}\right)$ and had a depth of approximately $7 \mathrm{~cm}(3 \mathrm{in})$. Surface flow was low in the bottom of the wash but was not measured. There was evidence (e.g., dry algae) to suggest that several small pools existed within the wash channel earlier in the year. Water quality measurements were taken in the wash pool in June 1996 and these data are presented in Table 5-2 (Section 5.0).

\subsubsection{Hydric Soils}

Field indicators at Wahmonie Seep 1 consisted of saturated soils for what appeared to be more than seven days during the growing season, indicating the presence of hydric soil. A soil pit was dug to determine the presence of other field indicators of hydric soils. Soils lacked evidence of mottling and dark colors (low chroma values). 


\subsubsection{Determination of Jurisdictional Status}

The wash channel of Wahmonie Seep, 1 would probably be considered a jurisdictional wetland because it has field indicators for all three required parameters: hydrophytic vegetation, wetland hydrology, and hydric soils.

\subsubsection{Wildlife Use}

Information on wildlife use of this site is limited. Desert cottontails, coyotes, Gambel's quail, mule deer scat, and passerine species of birds have been observed at the site.

\subsubsection{Wahmonie Seep 2}

\subsubsection{Site Description and Historical Use}

Wahmonie Seep 2 is located in a wash channel on the north-facing slope of Skull Mountain (Figure 4-21), about $2.1 \mathrm{~km}$ (1.3 mi) south of Cane Spring Road (Photo 4-54) and about $500 \mathrm{~m}(1,640 \mathrm{ft})$ up the drainage from Wahmonie Seep 1. A mine shaft is located east of Wahmonie Seeps 1 and 2 and some prospect markers (piles of rock) are also located in the area. There is no evidence, however, of disturbance of the seep by man.

\subsubsection{Hydrophytic Vegetation}

A wetland survey was conducted within the upper end of the wash channel on June 20, 1996. One dominant hydrophytic species, Emory's baccharis, was observed within the wetland plant community (Photo 4-55). Absolute canopy cover for this species was estimated to be 85 percent (Table 4-24). No dominant upland plant species were observed at this site; Louisiana sagewort and an unidentified moss were observed at the observation point but comprised only about 3 percent of the absolute canopy cover. The site was therefore dominated by hydrophytic vegetation which was restricted to a narrow corridor in the wash bottom comprising an area of about $150 \mathrm{~m}^{2}\left(1,614 \mathrm{ft}^{2}\right)$ (Table 5-1, Section 5.0). Plant species observed in the adjacent upland area included Louisiana sagewort, blackbrush, Nevada jointfir, Cooper's heathgoldenrod, eastern Mojave buckwheat, and Mexican bladdersage.

\subsubsection{Wetland Hydrology and Water Quality}

Field indicators of wetland hydrology were observed in the wash channel and consisted of surface water and saturated soils. On June 6,1996, surface water less than $5 \mathrm{~cm}$ ( 2 in) deep was observed in isolated small pools less than $0.25 \mathrm{~m}^{2}\left(2.7 \mathrm{ft}^{2}\right)$ in the wash bottom, but surface water was not observed on June 20,1996. Based on the presence of wetland species, surface water, and saturated soils as late in the growing season as June 6 , it was concluded that indicators of wetland hydrology were present. No water quality measurements were taken at this site. 


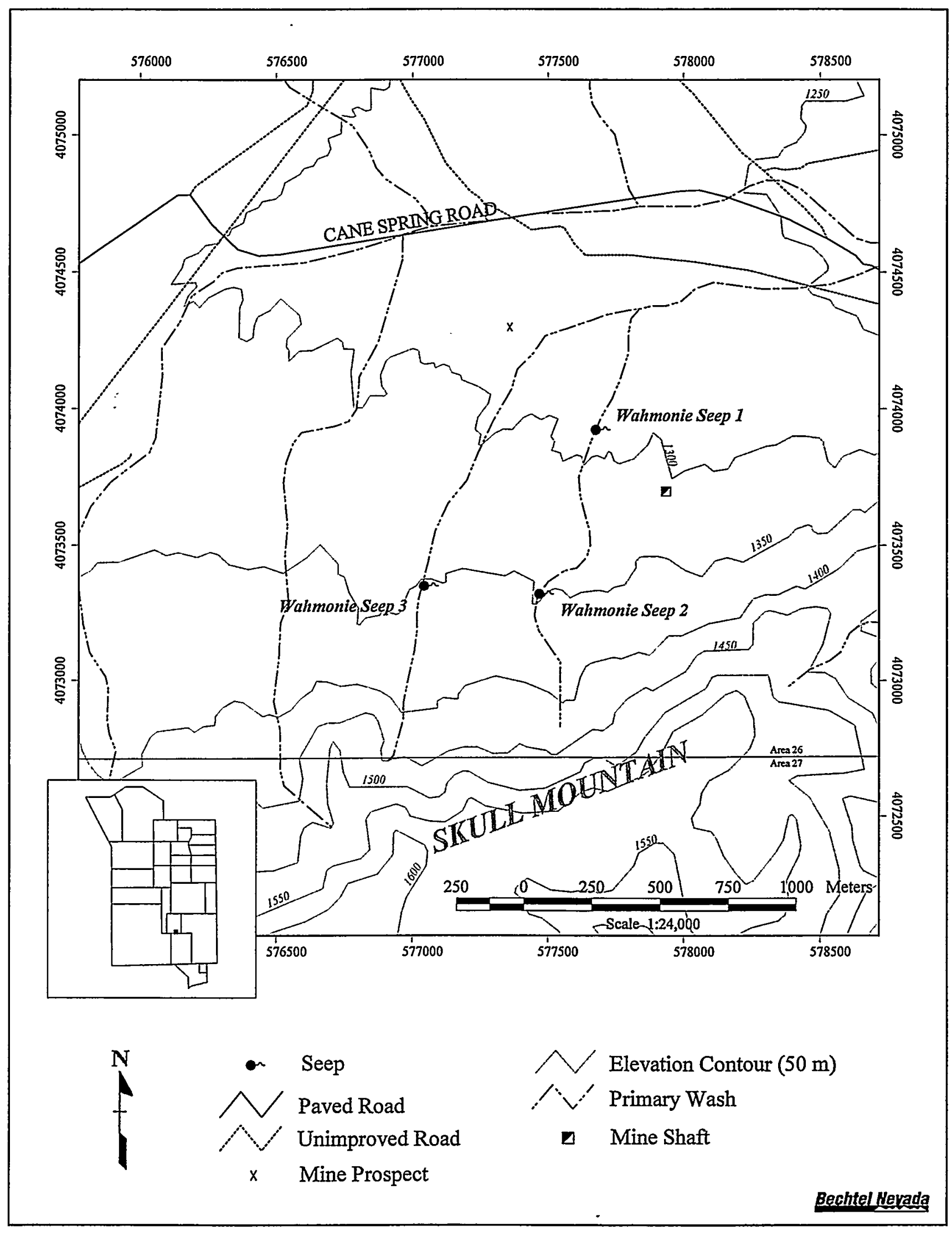

Figure 4-21 Location of Wahmonie Seep 2 


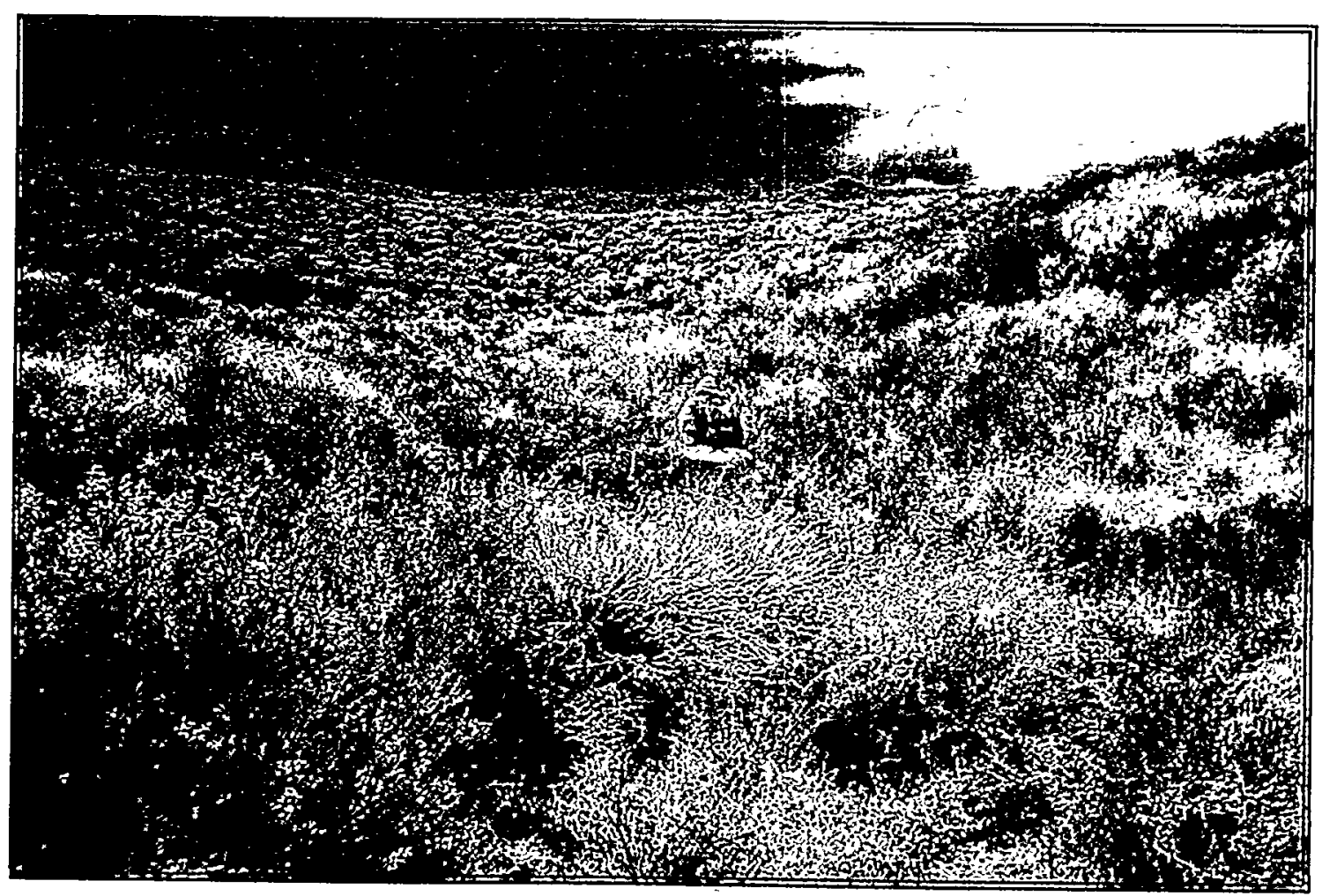

Photo 4-55 Wetland vegetation at Wahmonie Seep 2 looking south on June 20, 1996 (WS339-12.TIF)

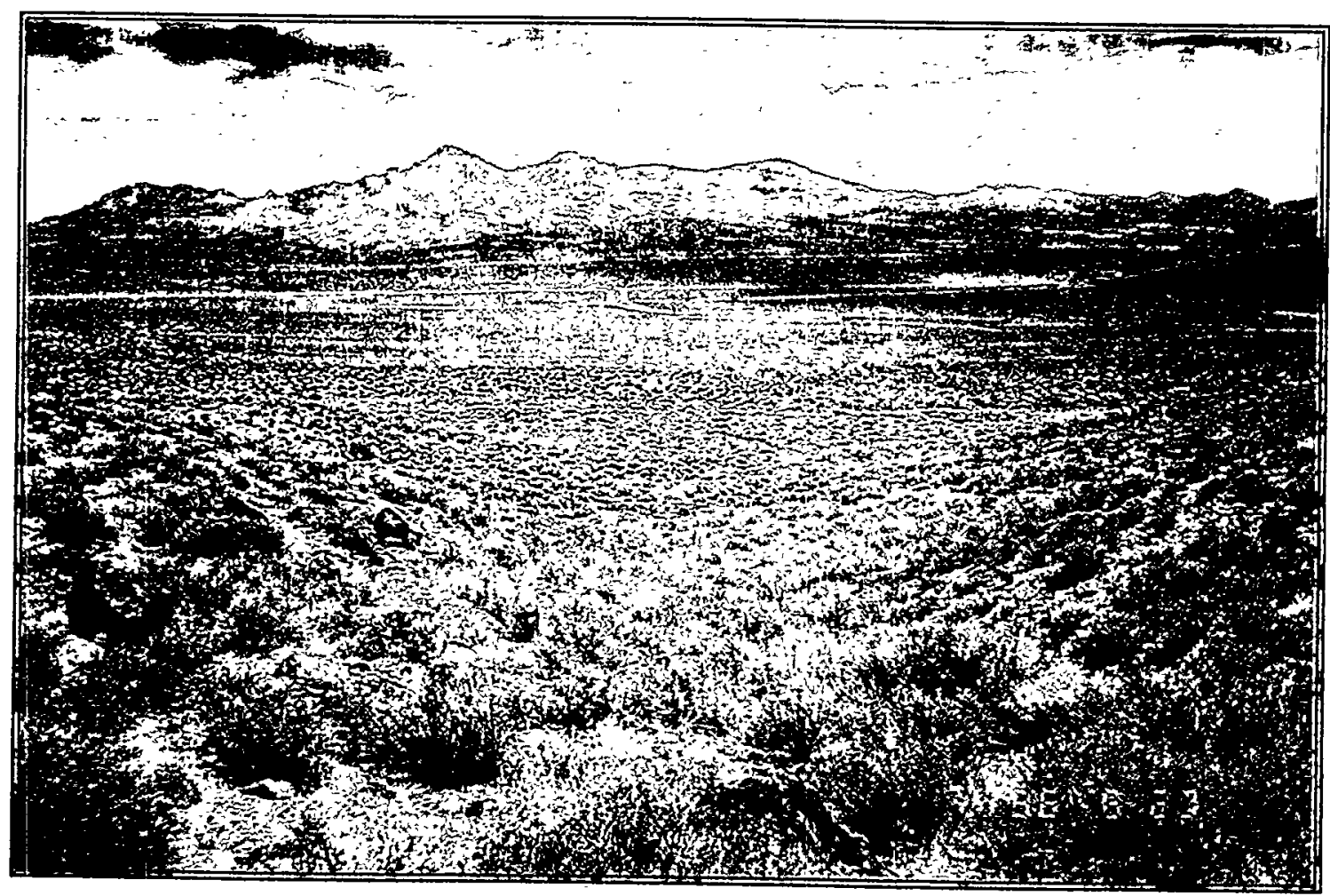

Photo 4-56 Wahmonie Seep 3 looking north on June 20, 1996 (WS339-13.TIF) 


\begin{tabular}{|c|c|c|c|}
\hline Species & Common Name & Indicator Status ${ }^{2}$ & Absolute \% Cover \\
\hline $\begin{array}{l}\text { Tree Layer: } \\
\text { no species }\end{array}$ & & & \\
\hline $\begin{array}{l}\text { Shrub Layer: } \\
\text { Baccharis emoryi }\end{array}$ & Emory's baccharis & FACW & 85 \\
\hline $\begin{array}{l}\text { Herb Layer: } \\
\text { Artemesia ludoviciana } \\
\text { unidentified moss }\end{array}$ & Louisiana sagewort & $\begin{array}{l}\text { FACU } \\
\text { UNKN }\end{array}$ & $\begin{array}{l}2 \\
1\end{array}$ \\
\hline
\end{tabular}

Hydrophytic vegetation: __ Yes

\subsubsection{Hydric Soils}

Biologists dug a soil pit and found saturated soils. No other hydric soil field indicators were observed. The soils were shallow, rocky, exhibited no mottling, and had little organic matter. Soils in the bottom of the wash channel at the seep appeared to have been saturated for more than seven days during the growing season, indicating the presence of hydric soils. The area of soil saturation appeared to correspond to the area dominated by Emory's baccharis.

\subsubsection{Determination of Jurisdictional Status}

A portion of the wash channel at Wahmonie Seep 2 would probably be considered a jurisdictional wetland because it has field indicators for all three required parameters: hydrophytic vegetation, wetland hydrology, and hydric soils.

\subsubsection{Wildlife Use}

Little is known about wildlife use of this seep. A bobcat skull was found near the seep suggesting use by this species. Desert cottontails, mule deer scat, and Gambel's quail were observed in the area on June 6, 1996. 


\subsubsection{Wahmonie Seep 3}

\subsubsection{Site Description and Historical Use}

Wahmonie Seep 3 is located on the north slope of Skull Mountain in a wash about $0.6 \mathrm{~km}$ (0.4 mi) due west of Wahmonie Seep 2 (Figure 4-22, Photo 4-56). There is no evidence that this seep has been used or developed by man.

\subsubsection{Hydrophytic Vegetation}

One dominant hydrophytic species (Emory's baccharis) and two dominant nonhydrophytic species (Louisiana sagewort and foxtail brome) were observed at this site within the wetland plant community (Table 4-25). Emory's baccharis comprised 60 percent of the absolute canopy cover, Louisiana sagewort comprised about 10 percent, and foxtail brome comprised about 30 percent. Louisiana sagewort was limited to the seep area and was not observed in the surrounding upland area. This species appeared dependent on the moisture from the seep. The presence and high percentage of cover of foxtail brome, an annual grass, is probably due to the fact that 1996 was a rather dry year which reduced soil saturation at the site, facilitating the invasion of foxtail brome into the seep. It was concluded that the vegetation of the site meets the criteria established for being considered hydrophytic vegetation. This was based on the fact that hydrophytic species comprised the largest proportion (60 percent) of the absolute canopy cover at the site (Williams, 1992). Hydrophytic vegetation was restricted to a narrow corridor in the wash channel of $180 \mathrm{~m}^{2}$ $\left(1,937 \mathrm{ft}^{2}\right)$ occupied by Emory's baccharis (Table 5-1, Section 5.0). Plant species in the upland area surrounding the seep included foxtail brome, blackbrush, eastern Mojave buckwheat, Virgin River brittlebush, Cooper's heathgoldenrod, rubber rabbitbrush, and Mojave yucca (Yucca schidigera).

\subsubsection{Wetland Hydrology and Water Quality}

Field indicators of wetland hydrology were observed on June 6, 1996, in a narrow corridor along the wash channel. These indicators consisted of surface water, water marks on rocks and vegetation, and salt encrustations observed along the bottom of the wash for a width of $3 \mathrm{~m}(10 \mathrm{ft})$ and a length of about $50 \mathrm{~m}(164 \mathrm{ft})$. The total area of surface water at the time of the survey was about $0.1 \mathrm{~m}^{2}\left(1 \mathrm{ft}^{2}\right)$. No water quality measurements were taken at this site.

\subsubsection{Hydric Soils}

Field indicators of hydric soils were present and restricted to a narrow of about $150 \mathrm{~m}^{2}$ $\left(1,615 \mathrm{ft}^{2}\right)$ corridor along the wash channel. This corridor had soils that appeared to have been saturated for longer than seven days during the growing season, indicating the presence of hydric soils. At the time of the survey, however, these soils were not saturated (Table 5-1, Section 5.0). Soils at this seep were shallow, rocky, and poorly developed. 


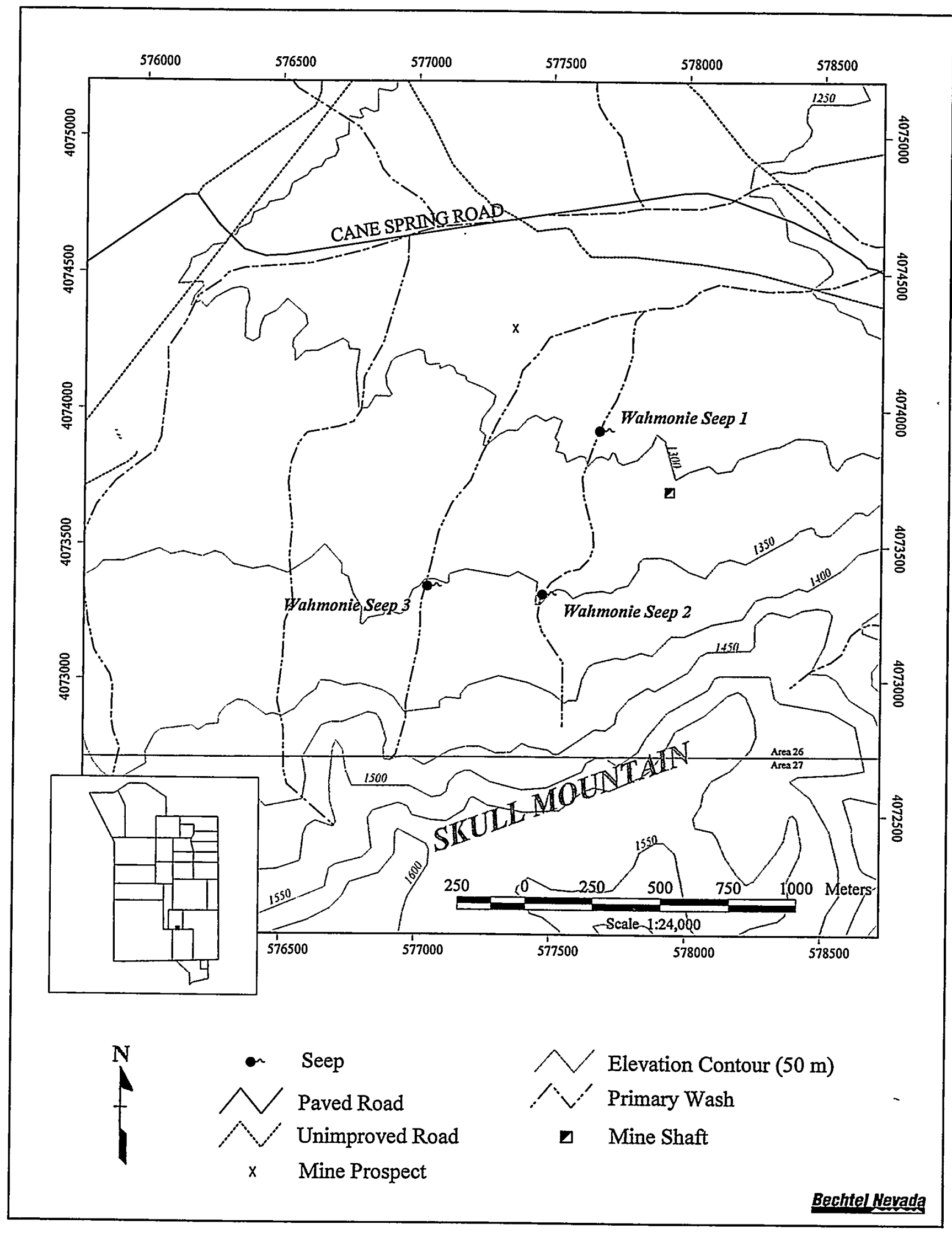

Figure 4-22 Location of Wahmonie Seep 3 


\begin{tabular}{|c|c|c|c|}
\hline Species & Common Name & Indicator Status ${ }^{\mathrm{a}}$ & Absolute \% Cover \\
\hline $\begin{array}{l}\text { Tree Layer: } \\
\text { no species }\end{array}$ & & & \\
\hline $\begin{array}{l}\text { Shrub Layer: } \\
\quad \text { Baccharis emoryi }\end{array}$ & Emory's baccharis & FACW & 60 \\
\hline $\begin{array}{l}\text { Herb Layer: } \\
\text { Artemesia ludoviciana } \\
\text { Bromus rubens }\end{array}$ & $\begin{array}{l}\text { Louisiana sagewort } \\
\text { foxtail brome }\end{array}$ & $\begin{array}{l}\text { FACU } \\
\text { UPL }\end{array}$ & $\begin{array}{l}10 \\
30\end{array}$ \\
\hline
\end{tabular}

Percentage of dominant plant species that are OBL, FACW, or FAC indicator status: $\frac{33}{\% \text {. }}$ Absolute \% cover due to all hydrophytic species present: $\quad 60 \quad \%$. Dominant plant species are indicated by bold Absolute \% Cover values.

${ }^{\mathrm{a}}$ For Region 8 indicator status codes for plants, see Section 3.2.4.

Hydrophytic vegetation: $\underline{\text { Yes* }}$

*Because the number of dominant hydrophytic species were equal to or less than the number of dominant nonhydrophytic species, an alternative method for determining the presence of hydrophytic vegetation was used (Williams, 1992; see Section 3.2.4).

\subsubsection{Determination of Jurisdictional Status}

The narrow corridor in the wash channel at Wahmonie Seep 3 would probably be considered a jurisdictional wetland because it had field indicators for all three required parameters: hydrophytic vegetation, wetland hydrology, and hydric soils.

\subsubsection{Wildlife Use}

Mule deer scat were located near the seep indicating use by this species. Other species use this area, but no observations were made during the limited sampling period.

\subsubsection{Whiterock Spring}

\subsubsection{Site Description and Historical Use}

Whiterock Spring is located in a wash at the northern end of Yucca Flat about $2.3 \mathrm{~km}$ (1.4 mi) east of the base of Rainier Mesa (Figure 4-23). This site was used as a winter camp by Native Americans from the Belted Range during the late 1800s to early 1900s (Stoffle et al., 1990a). A stone cabin and corral occur near the site which were used during the 1920s (Worman, 1969). Sixty mining claims were recorded from the Whiterock Spring area in 1928 (Stoffle et al., 1990a), suggesting that mining in the area occurred then. Ranching may have occurred in the area in the 1930s. Early ranchers or 

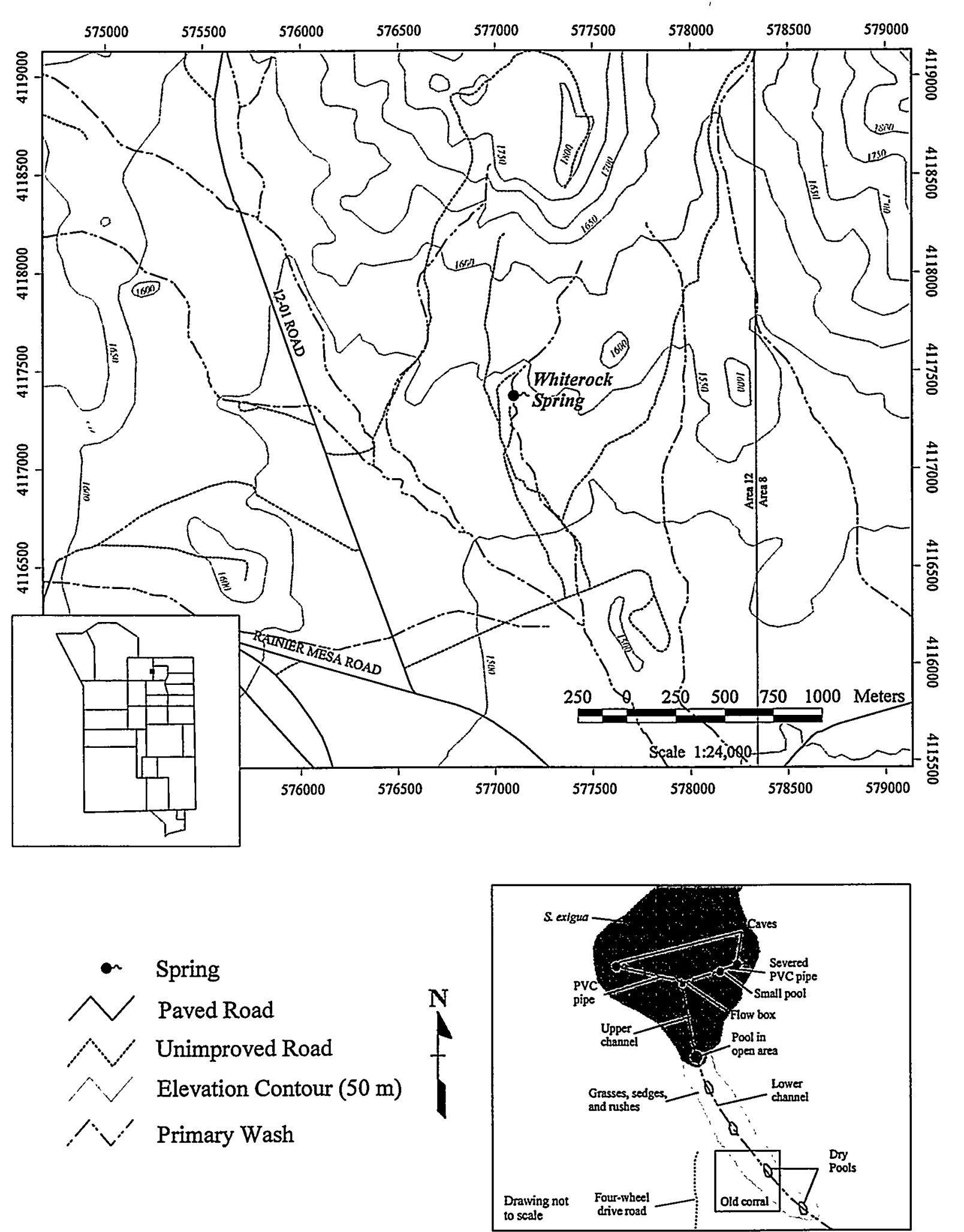

Figure 4-23 Location and sketch of Whiterock Spring

Bechtel Nevada 
miners tunneled into the hillside and installed pipes from the springs to a watering tank (Photos 4-57 and 4-58) (Worman, 1969). Two caves, one located on each side of the

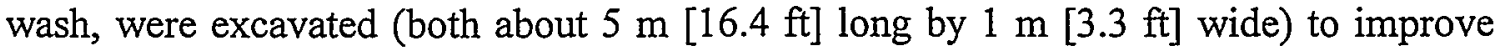
flow or store water. The east cave contained water $8 \mathrm{~cm}$ (3 in) in depth as determined by the height of the check dam. The east cave was open to sunlight and supported mosses and aquatic plants (Photo 4-59). The west cave was heavily shaded, contained water about $15 \mathrm{~cm}$ (6 in) deep, and supported no aquatic plants.

\subsubsection{Hydrophytic Vegetation}

Two plant communities were surveyed at Whiterock Spring (Tables 4-26 and 4-27). One community in the upper stretch of the wash was dominated by sandbar willow. There was an opening in the trees where a small surface pool occurs in dense grasses, sedges, and rushes (Photo 4-60). The other plant community in the lower stretch of the wash was dominated by Baltic rush. Other species present in the lower stretch of the wash outside the observation point included clustered field sedge, rubber rabbitbrush, basin wildrye, annual yellow sweetclover (Melilotus indicus), annual rabbitsfoot grass, and southern cattail. Beatley (1976) also recorded annual hairgrass (Deschampsia danthonioides), hairy willowherb (Epilobium ciliatum), foxtail barley, seep monkeyflower, willow dock, and broadleaf cattail (Typha latifolia) from Whiterock Spring. Plant species in the upland surrounding the spring included blackbrush, Gambel's oak, skunkbush sumac, and desert snowberry (Symphoricarpos longiflorus). One hundred percent of the dominant plant species were categorized as hydrophytic species at sampling locations in both the upper and lower stretches of the spring channel at Whiterock Spring. Hydrophytic emergent vegetation dominated by seep monkeyflower was observed in the west cave, but not the east cave. Whiterock Spring is the second largest wetland on the NTS, $1,800 \mathrm{~m}^{2}(19,369$ $\mathrm{ft}^{2}$ ), based on the area occupied by wetland vegetation (Table 5-1, Section 5.0).

\subsubsection{Wetland Hydrology and Water Quality}

Field indicators were observed at the two cave pools and the upper and lower stretches of the spring channel, indicating the presence of wetland hydrology at the site. Presently, one PVC pipe leads from each cave pool to a flow gauge box located in the middle of the wash. Flow from the east cave pours onto the ground from a broken pipe, forming a small pool about $3 \mathrm{~cm}$ ( 1 in) deep and $0.1 \mathrm{~m}^{2}\left(1.1 \mathrm{ft}^{2}\right)$ in area which drains through gravel. Flow from the west cave fills the flow box and overflows into the rocky, permeable substrate. The combined flow rate from both cave pools measured in September 1996 was approximately $1.9 \mathrm{\ell} / \mathrm{min}(0.5 \mathrm{gal} / \mathrm{min})$. Depth to inundation was measured through a partially buried pipe in the ground and was $45.7 \mathrm{~cm}$ (18 in). Downstream in the lower stretch of the wash, several dry ephemeral pools exist that contained field indicators of wetland hydrology such as dried algae on rocks. Water quality measurements were taken in the flow box in June and September 1996 and in the west cave pool in September 1996. These water quality data are presented in Table 5-2 (Section 5.0). 


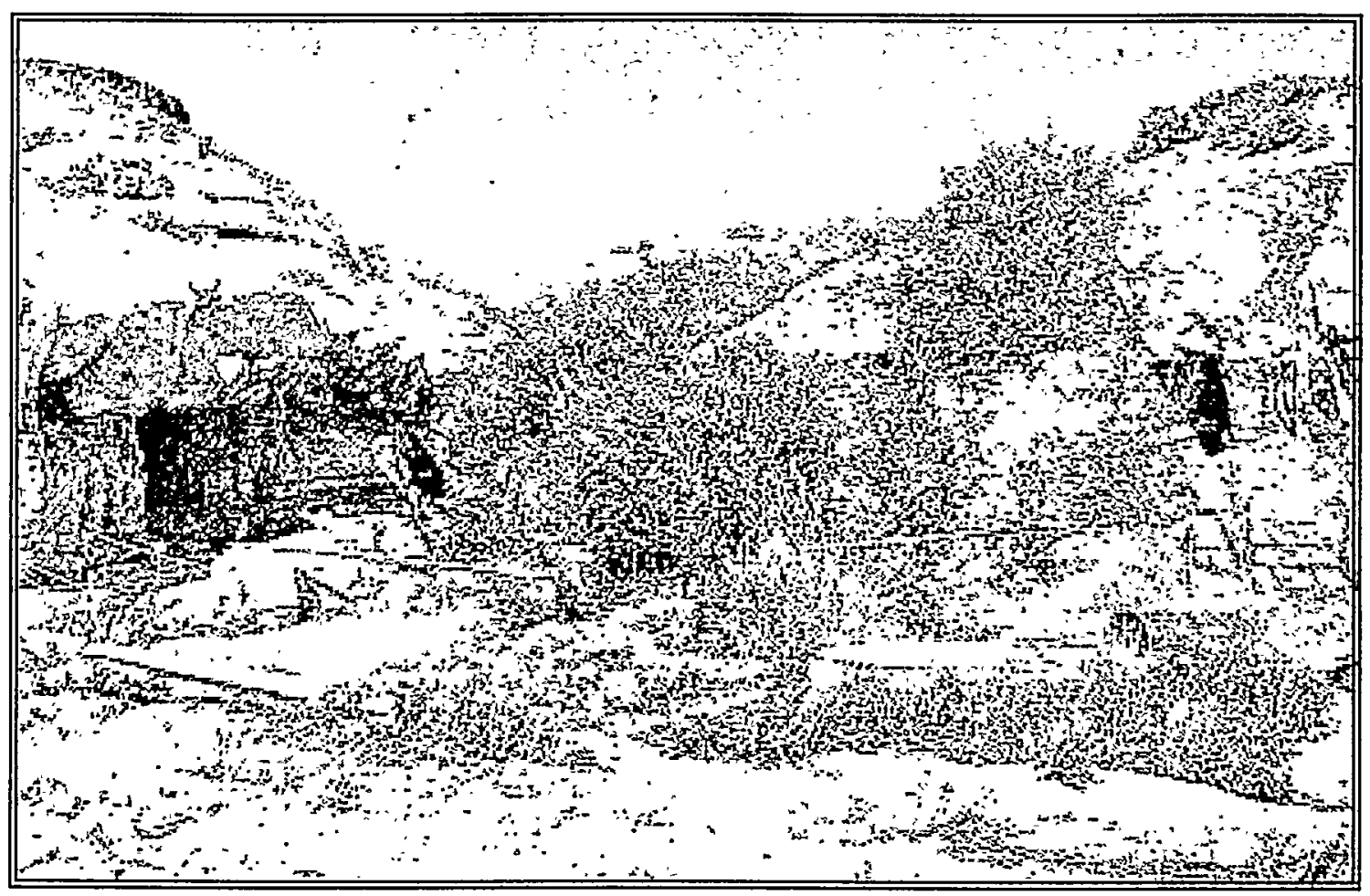

Photo 4-57 Whiterock Spring with grazed vegetation looking north about 1968 (WS505-02.TIF)

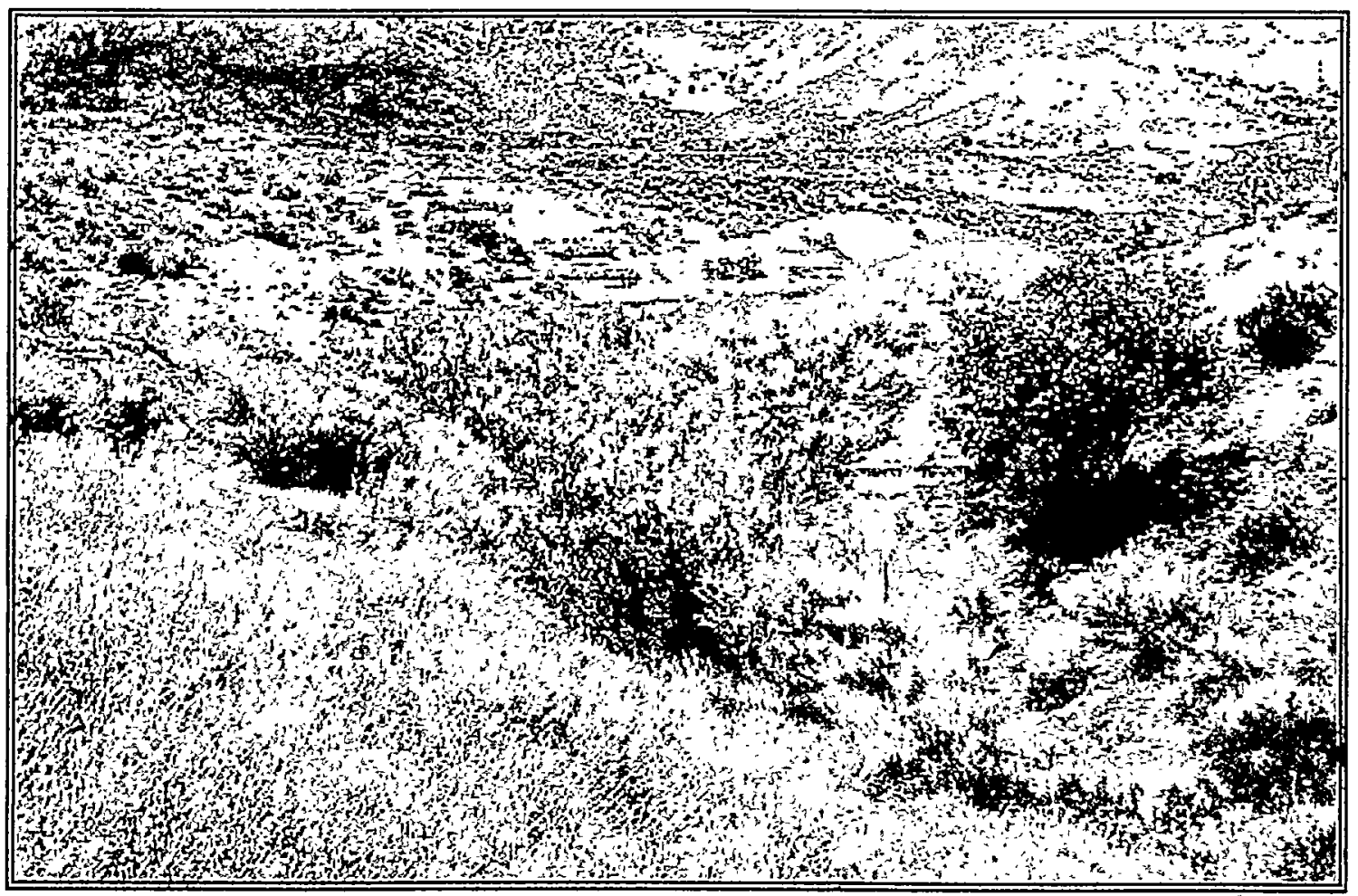

Photo 4-58 Whiterock Spring without grazing looking north on June 18, 1996 (WS341-31.TIF) 


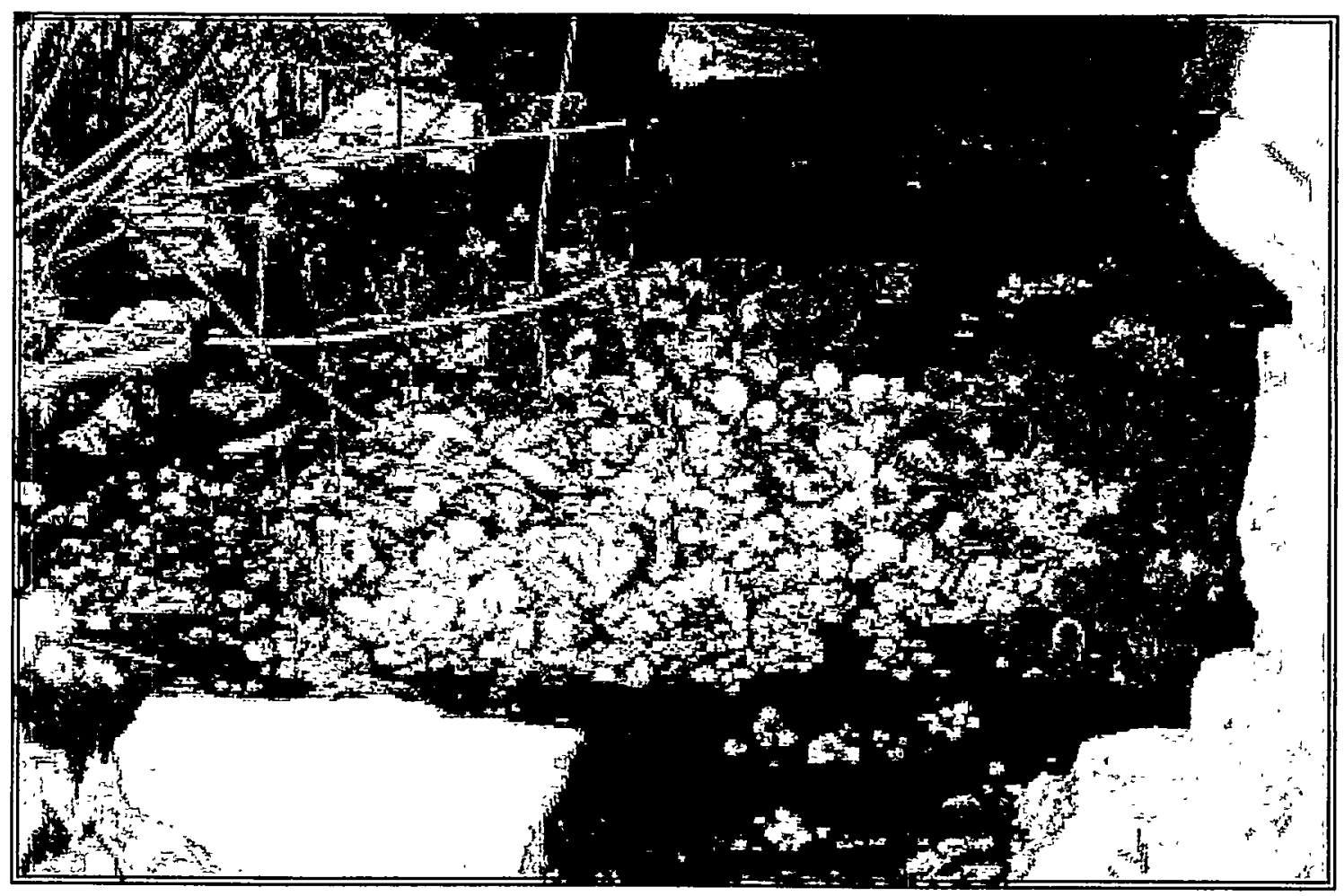

Photo 4-59 Emergent vegetation in the east cave of Whiterock Spring on December 7, 1990 (WS213-19.TIF)

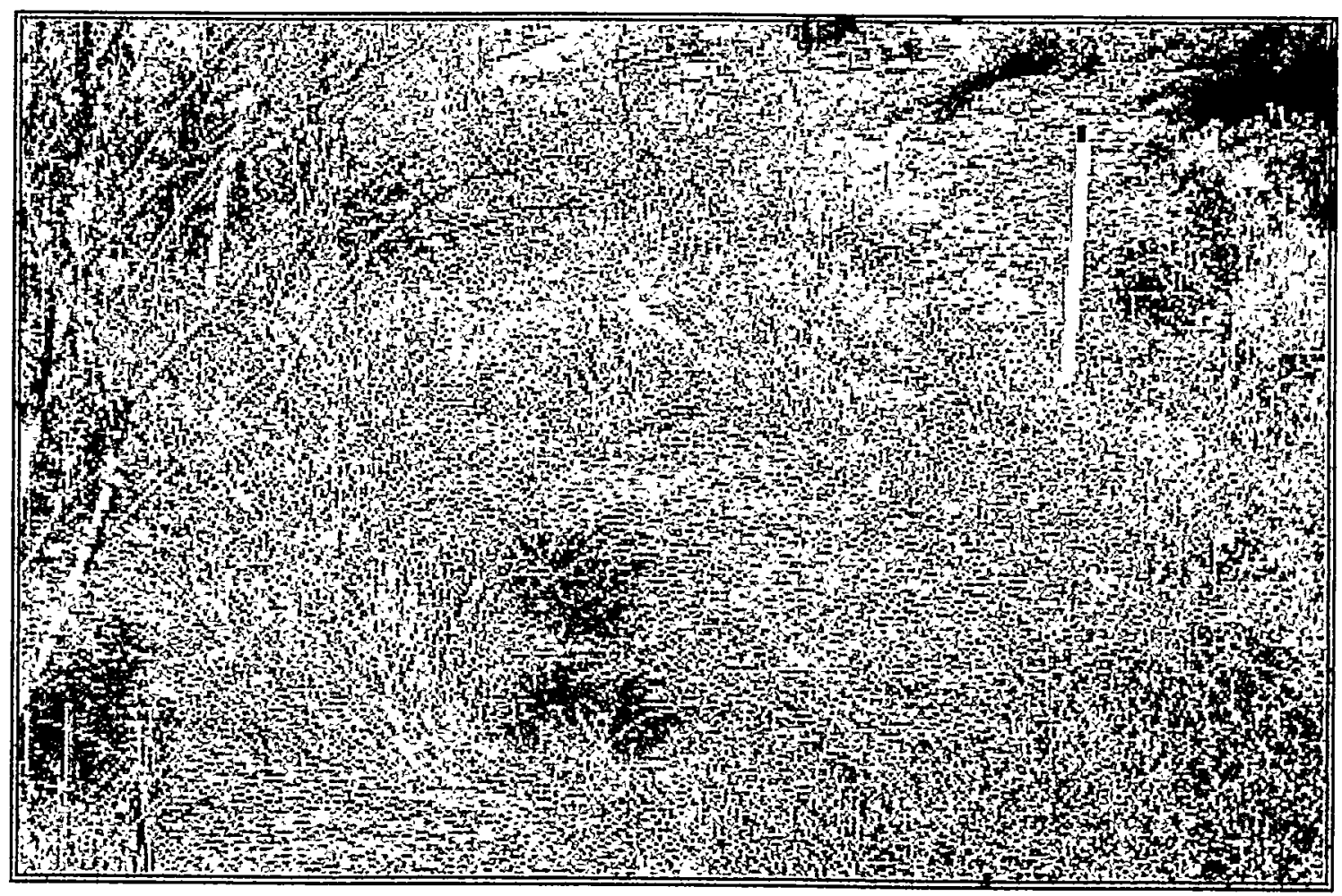

Photo 4-60 Surface pool at Whiterock Spring looking north on December 7, 1990 (WS213-17.TIF) 
Table 4-26 Whiterock Spring wetland vegetation as surveyed on June 18; 1996

\section{Habitat: Upper Stretch of Spring Channel}

\begin{tabular}{|c|c|c|c|}
\hline Species & Common Name & Indicator Status ${ }^{2}$ & Absolute $\%$ Cover \\
\hline $\begin{array}{l}\text { Tree Layer: } \\
\text { no species }\end{array}$ & & & \\
\hline $\begin{array}{l}\text { Shrub Layer: } \\
\text { Salix exigua }\end{array}$ & sandbar willow & FACW & 80 \\
\hline $\begin{array}{l}\text { Herb Layer: } \\
\quad \text { Potentilla biennis } \\
\text { Rumex salicifolius }\end{array}$ & $\begin{array}{l}\text { biennial cinquefoil } \\
\text { willow dock }\end{array}$ & $\begin{array}{c}\text { FAC } \\
\text { FACW* }\end{array}$ & $\begin{array}{l}\operatorname{Tr} \\
5\end{array}$ \\
\hline
\end{tabular}

Percentage of dominant plant species that are OBL, FACW, or FAC indicator status: $\frac{100}{\% \text {. }}$

Dominant plant species are indicated by bold Absolute $\%$ Cover values. $\mathrm{Tr}=$ trace, $<1 \%$ absolute cover.

${ }^{\mathrm{a}}$ For Region 8 indicator status codes for plants, see Section 3.2.4.

Hydrophytic vegetation: Yes

Table 4-27 Whiterock Spring wetland vegetation as surveyed on June 18, 1996

\section{Habitat: Lower Stretch of Spring Channel}

\begin{tabular}{|c|c|c|c|}
\hline Species & Common Name & Indicator Status ${ }^{2}$ & Absolute \% Cover \\
\hline \multicolumn{4}{|l|}{$\begin{array}{l}\text { Tree Layer: } \\
\text { no species }\end{array}$} \\
\hline \multicolumn{4}{|l|}{$\begin{array}{l}\text { Shrub Layer: } \\
\text { no species }\end{array}$} \\
\hline \multicolumn{4}{|l|}{ Herb Layer: } \\
\hline Artemesia ludoviciana & Louisiana sagewort & FACU & 2 \\
\hline Juncus balticus & Baltic rush & FACW & 94 \\
\hline Linum lewisii & prairie flax & NL & 1 \\
\hline Potentilla biennis & biennial cinquefoil & FAC & 1 \\
\hline Rumex salicifolius & willow dock & FACW* & $\operatorname{Tr}$ \\
\hline Sporobolus airoides & alkali sacaton & FAC- & $\operatorname{Tr}$ \\
\hline
\end{tabular}

Percentage of dominant plant species that are OBL, FACW, or FAC indicator status: $100 \%$.

Dominant plant species are indicated by bold Absolute \% Cover values. $\mathrm{Tr}=$ trace, $<1 \%$ absolute cover.

${ }^{a}$ For Region 8 indicator status codes for plants, see Section 3.2.4.

Hydrophytic vegetation: Yes 


\subsubsection{Hydric Soils}

Field indicators of hydric soils were observed at the cave pools and in the upper and lower stretches of the spring channel. Soils at these locations appeared to have been saturated for more than seven days during the growing season, indicating the presence of hydric soils. Soils at this site were very rocky and poorly developed. Soil pits were not dug at this site.

\subsubsection{Determination of Jurisdictional Status}

The eastern cave pool and the upper and lower stretches of the spring channel at Whiterock Spring meet the criteria to be considered jurisdictional wetlands. Field indicators for all three required parameters (hydrophytic vegetation, wetland hydrology, and hydric soils) were present at these sites. The western cave pool lacked hydrophytic vegetation, perhaps because of reduced light reaching the cave. This cave pool may be considered waters of the United States.

\subsubsection{Wildlife Use}

Wildlife species known to use this site include desert cottontails, black-tailed jackrabbits, mule deer, raptors, upland game species, and 12 species of passerine birds. Giles (1976) reported use of the area by horses, although no horses have been observed at the spring since horse monitoring began in 1988. The willow grove offers significant cover to migrating birds and raptors such as Cooper's hawks and long-eared owls.

\subsubsection{Yellow Rock Springs}

\subsubsection{Site Description and Historical Use}

The Yellow Rock Springs site occurs below a yellow tuff formation near the base of Fortymile Canyon (Figure 4-24, Photo 4-61). There appears to be little evidence of human disturbance at the spring except for numerous Native American rock shelters in the area. These rock shelters are located about $23 \mathrm{~m} \mathrm{(75} \mathrm{ft)} \mathrm{above} \mathrm{the} \mathrm{canyon} \mathrm{floor} \mathrm{(Stoffle}$ et al., 1990b). One rock shelter contained grinding slabs and a rock wall. It is believed that this area was used temporarily by Native Americans traveling through the area. The wash north of the site is believed to be the likely route used by Native Americans for collecting pinyon nuts on Shoshone Mountain (Stoffle et al., 1990b).

\subsubsection{Hydrophytic Vegetation}

A wetland vegetation survey was conducted at the Yellow Rock Springs site on December 19, 1996. From the observation point in the rocky wash, no wetland plant species were observed, indicating that hydrophytic vegetation was absent from this site (Table 4-28). Skunkbush sumac was the most dominant plant species and, although it is not considered a hydrophytic species, it appears to be restricted to moist soil habitats on the NTS. Skunkbush sumac and basin wildrye have not been observed in upland habitat around any of the NTS springs visited, and therefore these plants may serve as indicators 


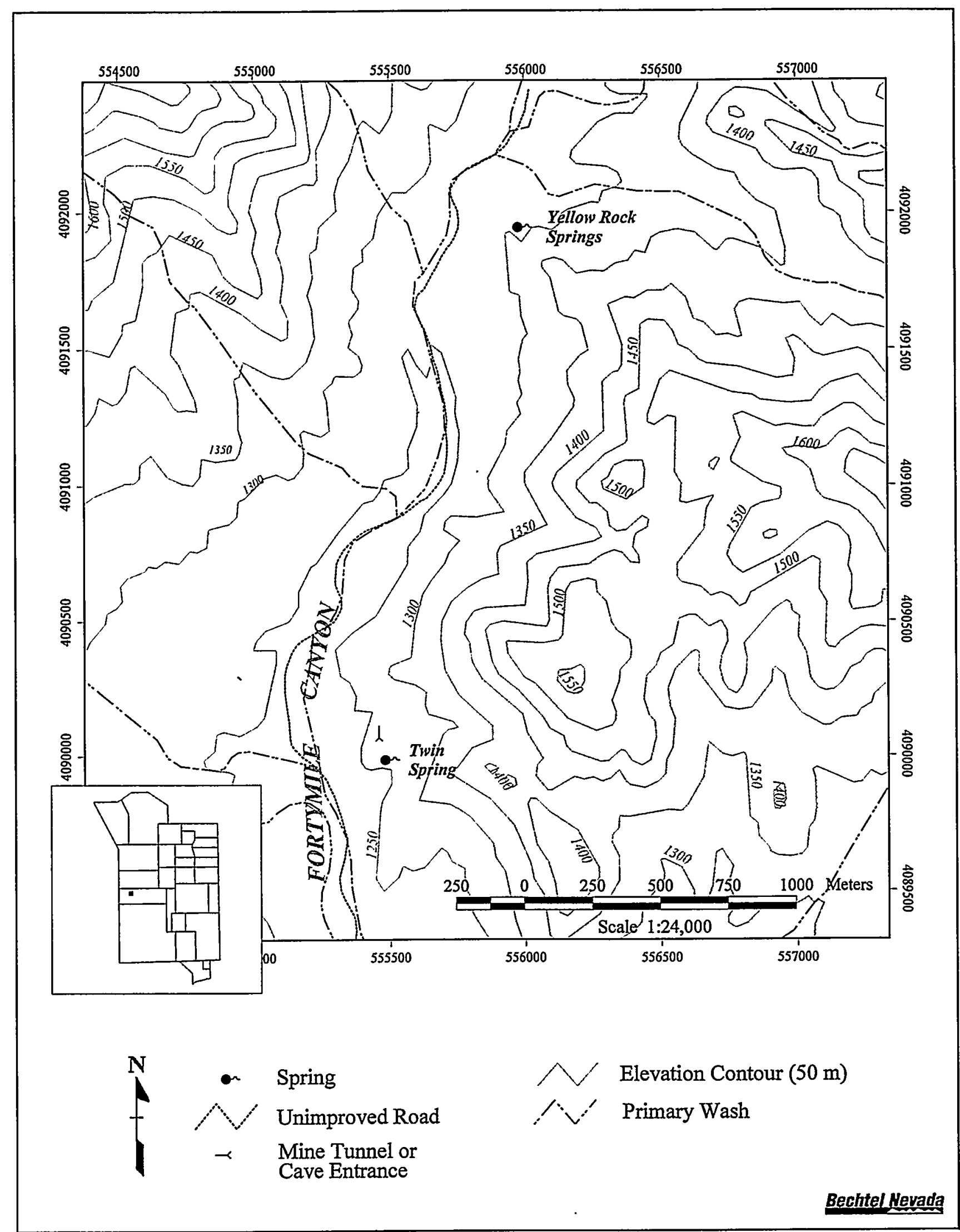

Figure 4-24 Location of Yellow Rock Springs 


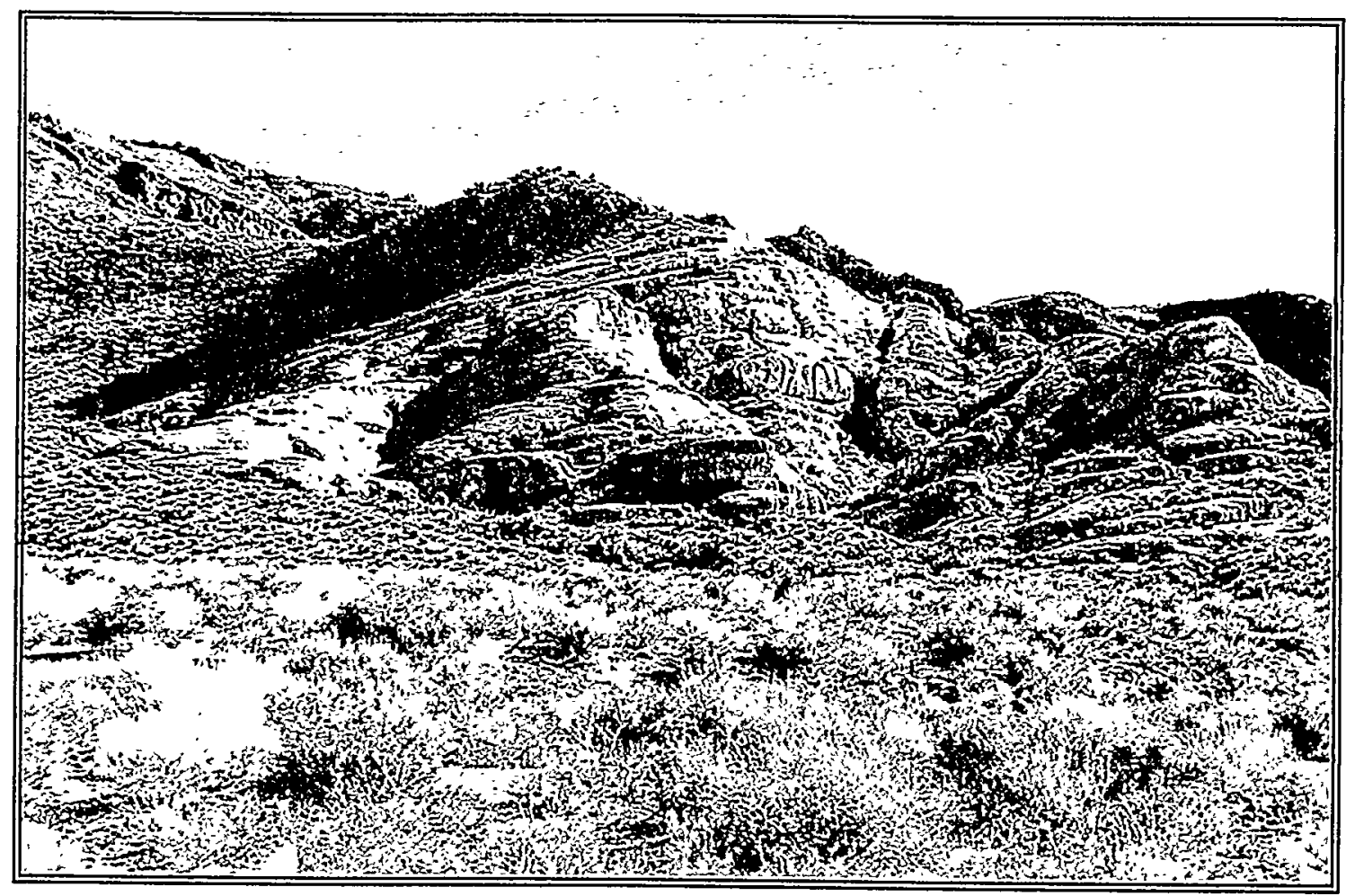

Photo 4-61 Habitat around Yellow Rock Spring looking southeast on January 29, 1997 (WS348-8.TIF)

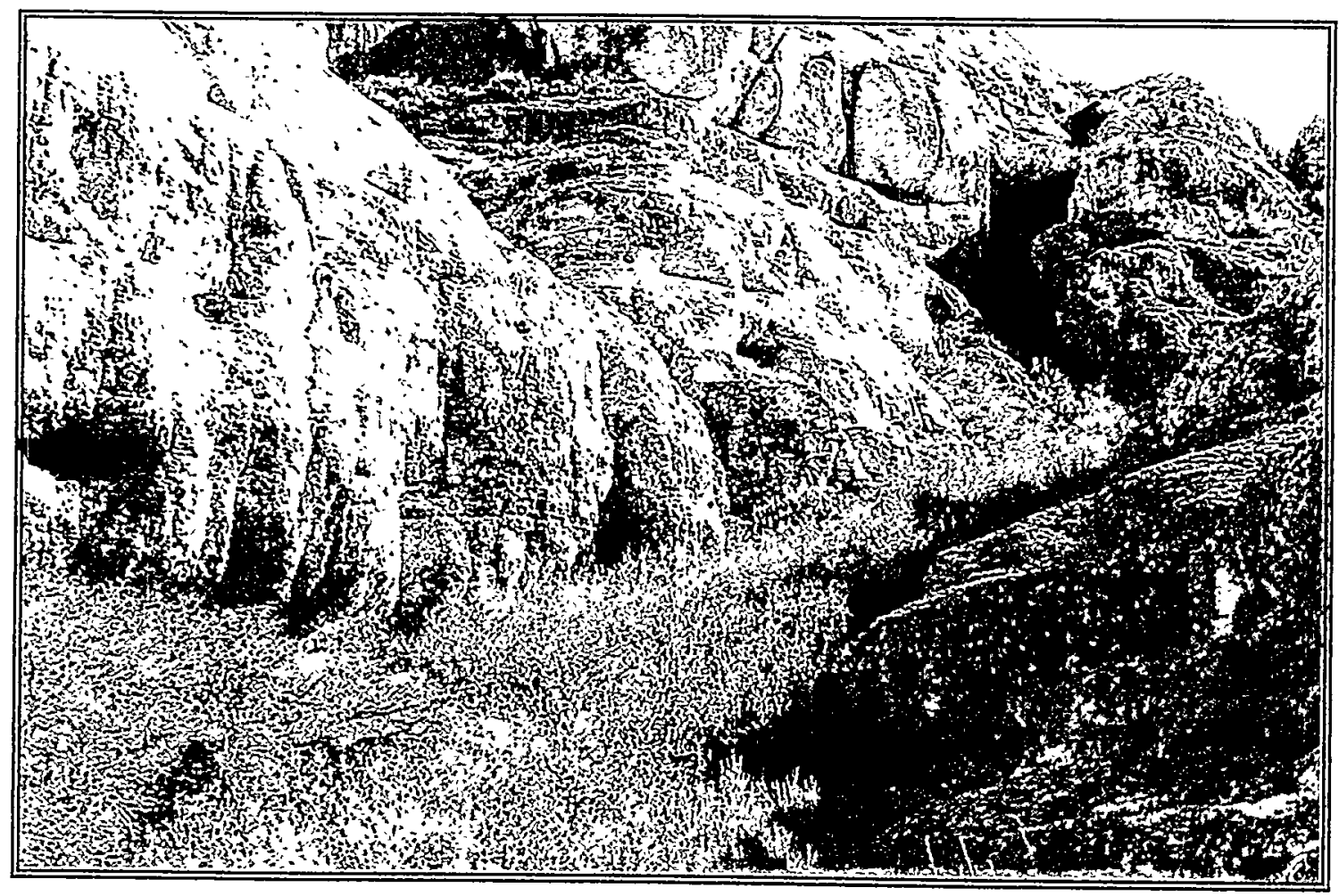
Photo 4-62 Drainage channel at Yellow Rock Spring looking southeast on January 29, 1997
(WS348-11.TIF) 


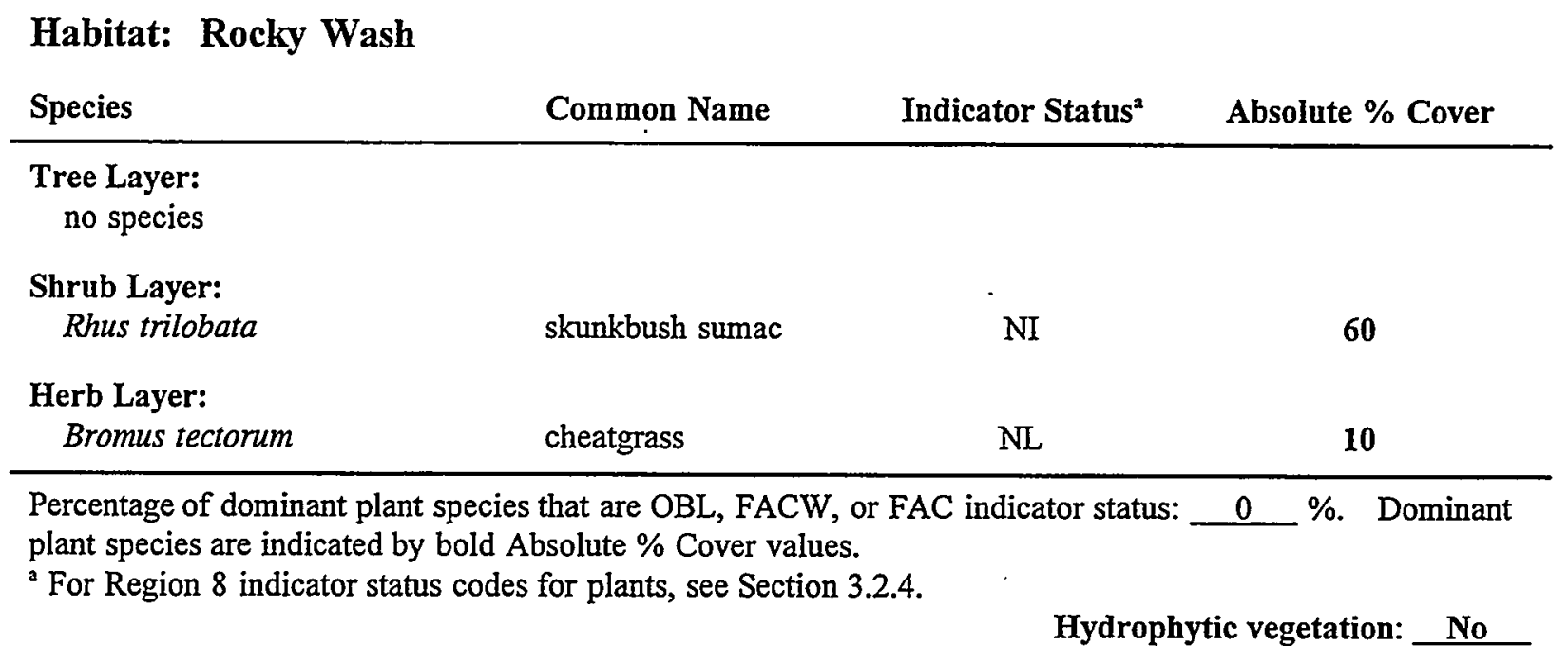

Hydrophytic vegetation: No

of moist soil conditions. Other plants observed in the upland area surrounding the sample area included cheatgrass, green rabbitbrush, mormon tea, and desert bitterbrush.

\subsubsection{Wetland Hydrology and Water Quality}

Field indicators of wetland hydrology were restricted to three narrow drainage channels at Yellow Rock Springs. Three spring sources were found in December 1996 corresponding to three spring symbols shown on the Topopah Spring USGS 7.5-Minute Series quadrangle map (1961). Water seeps out of rock fissures and flows down three drainage channels to the northwest for about $40 \mathrm{~m}$ (131 ft) (Photo 4-62). Numerous small surface pools occur in these rocky washes. The average pool size was about $1 \mathrm{~m}(3 \mathrm{ft})$ long by $0.25 \mathrm{~m}(0.8 \mathrm{ft})$ wide and $15 \mathrm{~cm}(6 \mathrm{in})$ deep. The pools were frozen at the time of the survey, and water quality measurements were not taken. The surface area of inundation was estimated to be about $30 \mathrm{~m}^{2}\left(323 \mathrm{ft}^{2}\right)$ (Table 5-1, Section 5.0).

\subsubsection{Hydric Soils}

Field indicators for hydric soils were present and appeared to be confined to isolated pockets of soil within bedrock fissures located in the three drainage channels. The floor of all three channels appeared to have been saturated for more than seven days during the plant growing season, indicating the presence of hydric soils. These drainage channels were predominantly rocky with little accumulation of soil fines.

\subsubsection{Determination of Jurisdictional Status}

Yellow Rock Springs would probably not be considered a jurisdictional wetland because it lacked field indicators for hydrophytic vegetation. 


\subsubsection{Wildlife Use}

Little is known about wildlife use of the spring. Mule deer appear to use the area, as indicated by the presence of scat found near the spring. Many species of passerine birds probably benefit from drinking at this site during summer months.

\subsubsection{Yucca Playa Pond}

\subsubsection{Site Description and Historical Use}

Yucca Playa Pond occurs west of Mercury Highway (Figure 4-25), about $50 \mathrm{~m}$ (164 ft) west of the Yucca Lake airplane landing strip and about $50 \mathrm{~m}(164 \mathrm{ft})$ north of Yucca Lake weather station. The ephemeral pond occurs in a low spot on the west side of Yucca Lake playa where water appears to collect naturally from playa drainage (Photo 4-63). It is comprised of four to five connecting lobes or smaller attached ponds. Water depth determines the extent to which the ponds are connected into one larger pond. It is not known if this pond is natural or human-enhanced, although evidence suggests that it is natural. Four fault lines converge beneath the pond and may have caused subsidence from earth movement associated with these faults (Fernald et al., 1968; McKeown et al., 1976). The pond area is labeled the "Railroad Tanks" on the Yucca Lake USGS 7.5-Minute Series quadrangle map (1986). The pond appears to be one of the lowest spots on Yucca Lake playa, based on elevational contour lines. The pond was present in black and white aerial photographs taken in 1964 (photos in the possession of Dennis Gustafson, Senior Geologist/Hydrologist with BN). The 1964 photos did not show evidence of human disturbance except for construction of a small rectangular berm about $70 \mathrm{~m}(230 \mathrm{ft})$ long by $21 \mathrm{~m}$ ( $69 \mathrm{ft}$ ) wide, positioned diagonally within the northernmost lobe of the pond. No other evidence of excavation or berms around the pond was observed during the site survey.

\subsubsection{Hydrophytic Vegetation}

From the observation point at the south edge of the pond, 100 percent of the dominant plants were hydrophytic species (Table 4-29). Saltcedar was the dominant wetland species

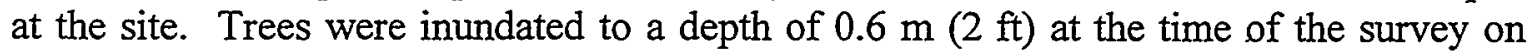
January 7,1997 . There were approximately 50 trees growing around the pond with each tree having an average area of about $34 \mathrm{~m}^{2}\left(366 \mathrm{ft}^{2}\right)$. About 6 percent of the total pond area was covered with trees. The narrow band of saltcedar around the edges of the ephemeral pond defines the wetland plant community dominated by hydrophytic vegetation. Aerial photographs taken in 1964 did not reveal the same pattern of trees around the pond as are seen in aerial photographs taken in 1994, suggesting that saltcedar has colonized the site since 1964. Photo interpretation of the 1964 photos suggest that there may have been about six large shrubs around the pond at that time, and it is unknown if these shrubs were saltcedar or other plant species. Only one other species was observed around the pond edge, southern cattail, which was limited to one small clump of about $1 \mathrm{~m}^{2}\left(11 \mathrm{ft}^{2}\right)$ in the north end of the pond. There was no evidence of other herbaceous vegetation within the pond during the site survey in January 1997. The hydrophytic vegetation surrounding Yucca Playa Pond covered an estimated area of $3,400 \mathrm{~m}^{2}(36,597$ $\left.\mathrm{ft}^{2}\right)$ (Table 5-1, Section 5.0). 


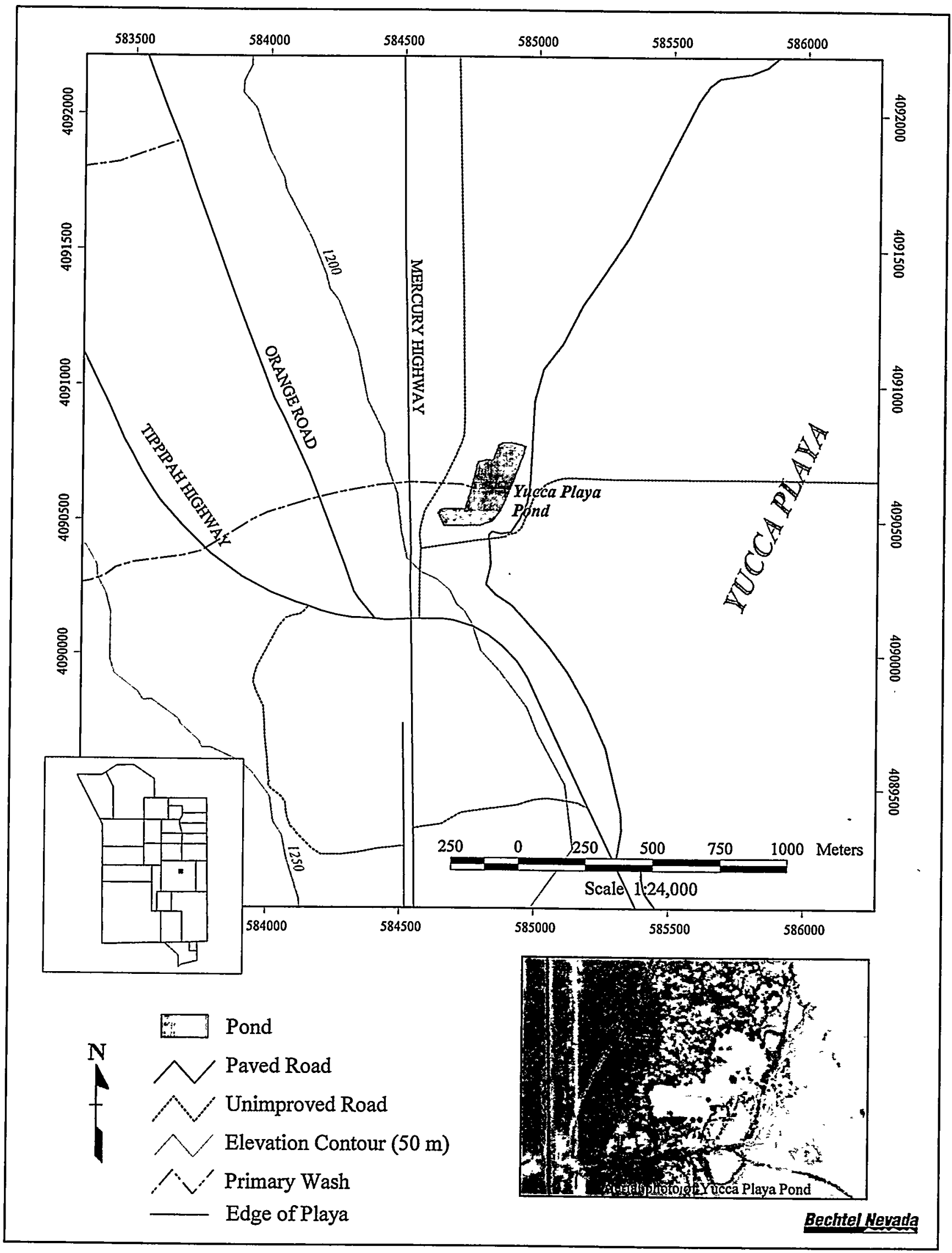

Figure 4-25 Location and aerial photo of Yucca Playa Pond 


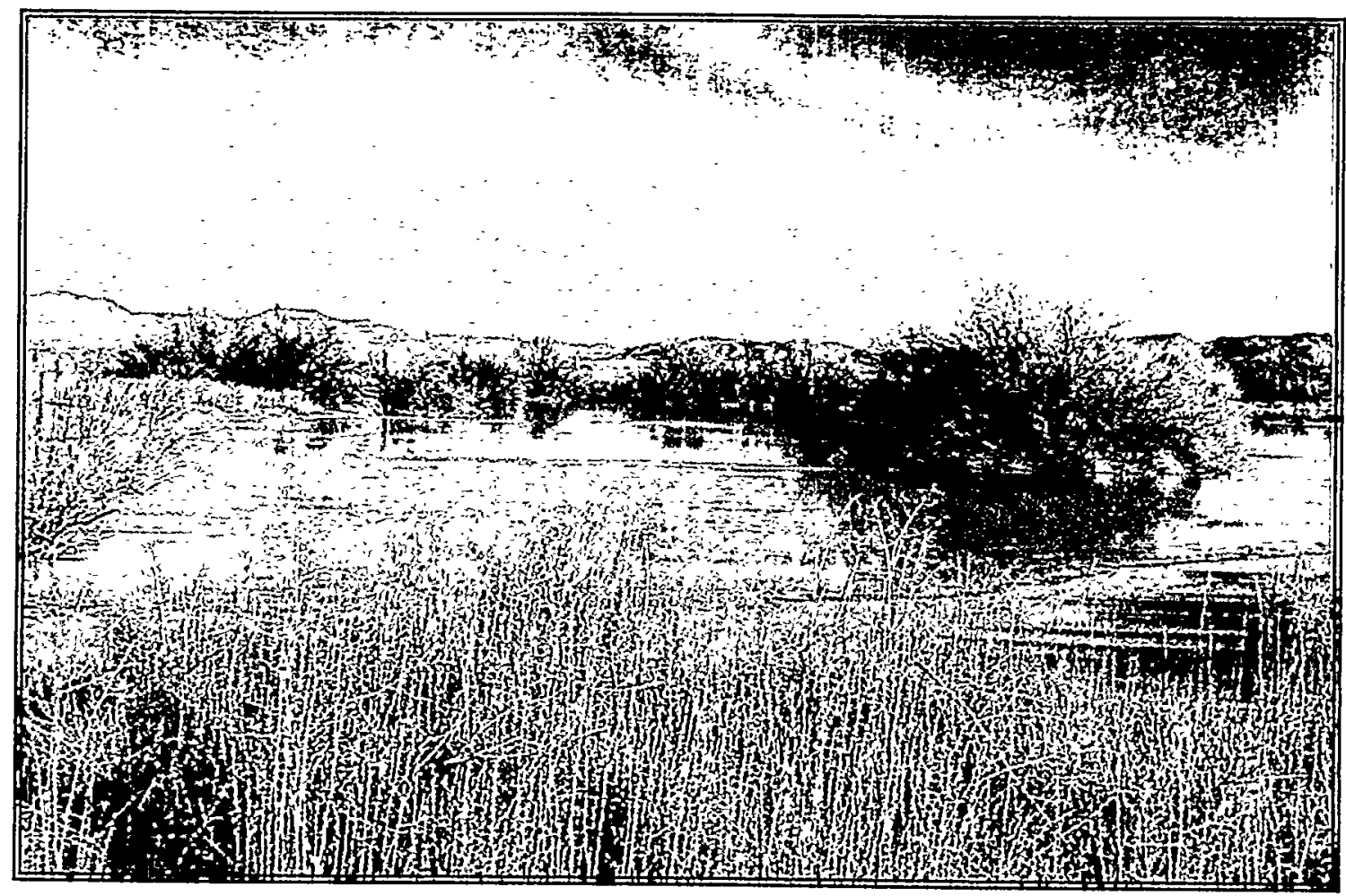

Photo 4-63 Emergent vegetation at Yucca Playa Pond looking north on January 7, 1997 (WS346-10.TIF)

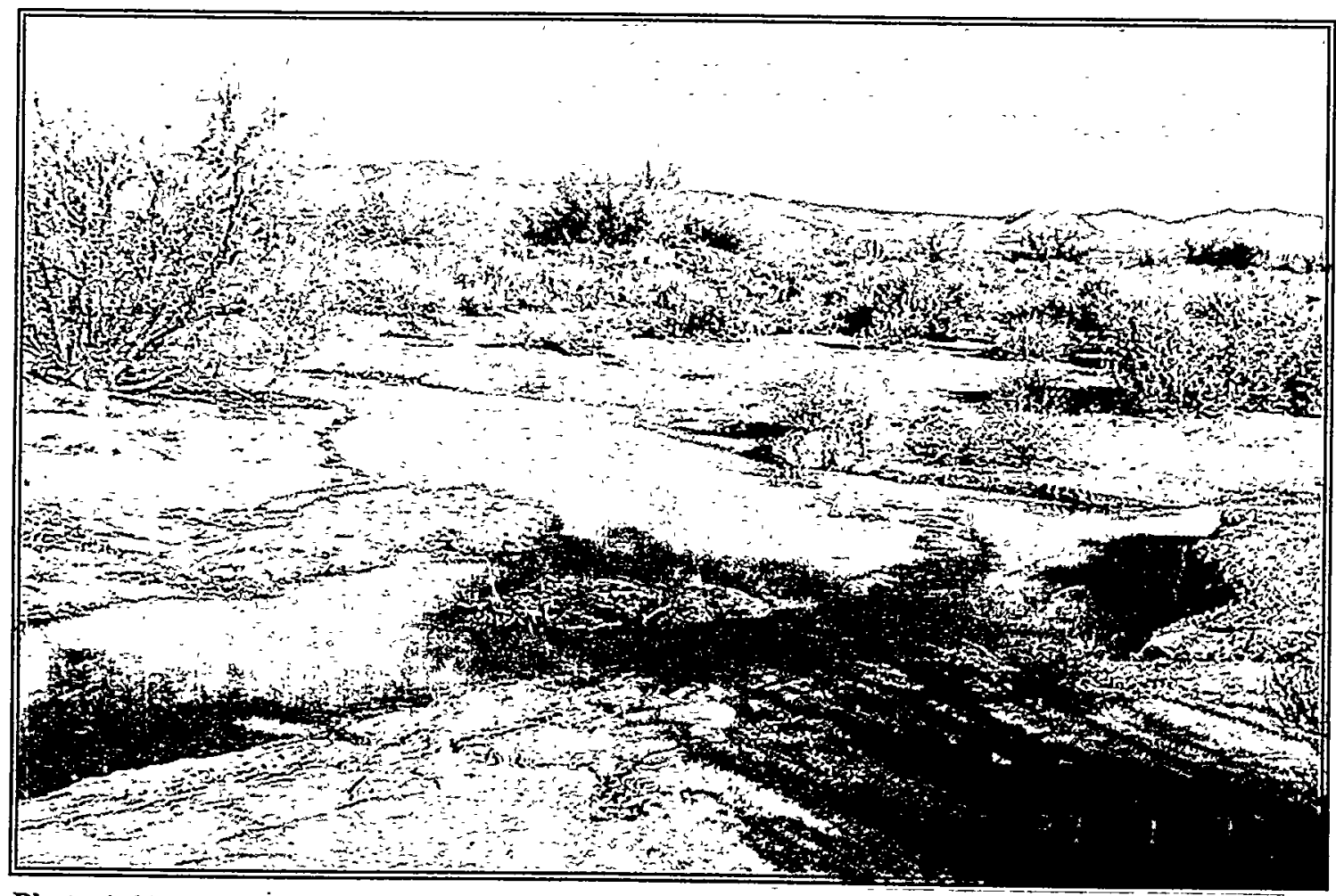

Photo 4-64 Drainage channel entering Yucca Playa Pond looking northwest on January 7, 1997
(WS346-06.TIF) 
Table 4-29 Yucca Playa Pond wetland vegetation as surveyed on January 7, 1997

\begin{tabular}{|c|c|c|c|}
\hline Species & Common Name & Indicator Status ${ }^{2}$ & Absolute \% Cover \\
\hline $\begin{array}{l}\text { Tree Layer: } \\
\text { Tamarix ramosissima }\end{array}$ & saltcedar & FACW & 20 \\
\hline $\begin{array}{l}\text { Shrub Layer: } \\
\text { no species }\end{array}$ & & & \\
\hline $\begin{array}{l}\text { Herb Layer: } \\
\text { Typha domingensis }\end{array}$ & southern cattail & OBL & $\operatorname{Tr}$ \\
\hline
\end{tabular}

Hydrophytic vegetation: Yes

Upland vegetation surrounding Yucca Playa Pond was quite diverse and somewhat weedy. Key species of plants included fourwing saltbush, cheatgrass, bottlebrush squirreltail, halogeton (Halogeton glomerata), prickly Russian thistle (Salsola paulsensii), talltumblemustard (Sisymbrium altissimum), Joshua tree, and several herbs and grasses that were not identified because of a lack of distinguishing taxonomic characteristics at the time of the site survey in January of 1997.

\subsubsection{Wetland Hydrology and Water Quality}

Field indicators of wetland hydrology were present at Yucca Playa Pond. Field indicators included surface water at the pond (also observed in previous years) and a well-eroded shoreline, apparently from wave action, which was barren of vegetation. Several drainage channels direct water off the playa into the pond (Photo 4-64). The surface area of the pond measured approximately $22,930 \mathrm{~m}^{2}\left(246,840 \mathrm{ft}^{2}\right)$ or $2.3 \mathrm{ha}(5.7 \mathrm{ac})$ (Table $5-1$, Section 5.0). Depth of water in January 1997 appeared to be about $150 \mathrm{~cm}$ (59 in), although the exact depth could not be determined because of ice. No springs or seeps are known to contribute water to the pond, and water supply appears to be primarily from surface runoff from precipitation events during winter months. It is likely that water persists within the ephemeral pond during the spring but dries during the summer. Water quality measurements were taken on January 7, 1996, and data are presented in Table 5-2 (Section 5.0).

\subsubsection{Hydric Soils}

Field indicators of hydric soils consisted of saturated soil within the pond. The soil appeared to remain saturated for more than seven days during the plant growing season 
(although persistence of the water into the growing season was not actually observed, but estimated), indicating the presence of hydric soils. Hydric soils were confined to the edges and bottom of the pond. The soil appeared to contain abundant clays and silts and may have been saline during the summer when evaporating water would concentrate soluble salts.

\subsubsection{Determination of Jurisdictional Status}

The pond edges of Yucca Playa Pond meet the criteria to be considered a jurisdictional wetland because they have field indicators of all three wetland parameters: hydrophytic vegetation, wetland hydrology, and hydric soils. The jurisdictional wetland zone around the pond is located between the uplands and the deeper unvegetated areas of the pond. It is characterized by the presence of saltcedar which grows in a narrow band around the edge of the pond. The deeper areas of the pond were inundated at the time of the survey and contained no evidence of vegetation. These areas would not be considered jurisdictional wetlands because they lack hydrophytic vegetation, but may be considered waters of the United States. The length of time water persists within the pond into the plant growing season and the colonization of the pond bottom and sides by herbaceous vegetation is unknown and will require further study to determine site conditions during spring and summer months.

\subsubsection{Wildlife Use}

Many birds are known to use this pond including chukar, great blue herons (Ardea. herodias), great-horned owls (Bubo virginianus), and many species of ducks (Romney and Greger, 1992). In the past, flocks of up to 40 ducks have been observed on the pond at one time. Mule deer and coyotes use the area as indicated by the presence of scat found near the pond. Many species of passerine birds probably benefit from drinking at this site during summer months following precipitation events. Three kinds of shrimp (fairy, tadpole, and clam) have been identified from the pond (Starkweather, 1996).

\subsubsection{Potential Man-Induced Wetlands}

In addition to the natural seeps, springs, and Yucca Playa Pond, there are numerous wetlands on the NTS that are man-induced. These sites are mentioned in general in this section, but no field surveys of these sites were conducted to determine their jurisdictional status. A man-induced wetland is an area that has developed at least some characteristics of naturally occurring wetlands due to either intentional or incidental human activities. Examples of man-induced wetlands include sumps, lagoons, ponds, and ditches fed by wells, and wetlands resulting from excavation. In virtually all cases, man-induced wetlands involve a significant change in the hydrologic regime, which may either increase or decrease the wetness of the area. Indicators of hydric soils are usually poorly represented or absent, while indicators of hydrophytic vegetation and wetland hydrology are more apparent. As mentioned in Section 3.1, some man-induced wetlands are not subject to Section 404 of the CWA. For example, if hydrophytic vegetation is maintained only by wetland hydrology that would no longer exist if an activity (e.g., irrigation) were to be terminated, the area is not considered a jurisdictional wetland. Two areas on the NTS known to support man-induced wetlands include Frenchman Lake and Yucca Flat. 
Within Frenchman Lake, more than 24 known areas have been excavated during construction of instrumentation sheds and other support facilities associated with historic aboveground nuclear tests conducted on the playa. These excavations vary in size and shape and are estimated to range between 1 ha $(2.5 \mathrm{ac})$ and $100 \mathrm{~m}^{2}\left(1,076 \mathrm{ft}^{2}\right)$ with a

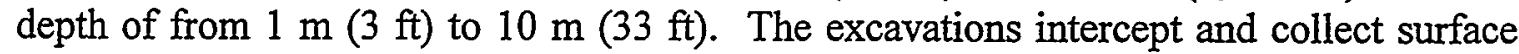
runoff after storms and periodically fill with water. One of the three field indicators needed for a site to be considered a jurisdictional wetland is the presence of hydrophytic vegetation, which around these excavations consists almost exclusively of saltcedar trees. The presence of the other two required field indicators, wetland hydrology and hydric soils, is questionable and will require further study to determine if ponded water and saturated soils persist long enough into the growing season to be considered wetland hydrology and hydric soils. The presence of hydric soils at these sites is questionable because saturation within the upper $46 \mathrm{~cm}$ (18 in) of the soil does not appear to occur. At the majority of the 24 known excavations, the soil supporting the roots of these trees does not appear to be saturated near the soil surface, and it appears that the only time the upper $46 \mathrm{~cm}$ (18 in) of soil would be saturated is immediately following a precipitation event. The saturated soil zone appears to be located 1 to $2 \mathrm{~m}$ ( 3 to $6 \mathrm{ft}$ ) deep and, therefore, would not meet the criteria needed to be considered hydric soils. If these excavations do not meet the criteria for jurisdictional wetlands they would, however, still be considered waters of the United States by virtue of the fact that they are located on Frenchman Lake (see Section 4.2.27).

Within Yucca Flat, numerous subsidence craters created by historical belowground nuclear tests retain surface water and support hydrophytic vegetation. These craters are another category of man-induced wetlands. These circular depressions (typically about $150 \mathrm{~m}$ [500 ft] in diameter and $20 \mathrm{~m}$ [70 ft] in depth) also intercept and collect surface runoff after storms, and many of them support hydrophytic vegetation (again, mostly saltcedar trees).

Vegetation within the craters of Yucca Flat and the excavations on Frenchman Lake may be mapped during 1997 as part of the continuing vegetation mapping of the NTS. Further assessments will be made of these areas only when a proposed NTS project may affect them. At that time, the presence of field indicators positive for jurisdictional wetlands would be determined.

\subsubsection{Waters of the United States}

There are other natural bodies of water on the NTS that are unvegetated but which attract wildlife and are therefore considered important biological resources. These water bodies include Yucca and Frenchman lakes which periodically flood during heavy precipitation and are known to offer seasonal habitat to migratory waterfowl. Although they are not wetlands by definition, they qualify as waters of the United States. Waters of the United States is a broad category of waters under the jurisdiction of the USACE as authorized under the CWA. They include "... waters such as intrastate lakes, rivers, streams (including intermittent streams), mudflats, sandflats, wetlands, sloughs, prairie potholes, wet meadows, playa lakes or natural ponds ...." 
The exact boundaries of the waters of the United States on both Yucca and Frenchman lakes are yet to be delineated using detailed topographic maps and field observations, although the upper elevation boundary (the "ordinary high water mark") is often approximated by the high water mark created during a 100-year storm of six hours duration. At Yucca Lake, this upper elevation is estimated at 1,196.3 m mean sea level (msl) $(3,925 \mathrm{ft} \mathrm{msl})$ with an area of approximately 2,016 ha (4,982 ac) (Raytheon Services Nevada, 1994). This water level is located approximately at the edge of the unvegetated playa. At Frenchman Lake, the 100-year, 6-hour model elevation is estimated at $939 \mathrm{~m}$ msl $(3,080 \mathrm{ft} \mathrm{msl})$, and no estimate of area has been made (Julianne Miller, Hydrologist [BN], personal communication, March 3, 1997). This water level is also located approximately at the edge of the unvegetated playa. 


\subsection{DISCUSSION AND SUMMARY OF NTS WETLANDS}

\subsection{Jurisdictional Wetlands Determination}

Sixteen of the 25 NTS study sites surveyed in 1996 and 1997 met the three required criteria (hydrophytic vegetation, wetland hydrology, and hydric soils) to be considered jurisdictional wetlands (Figure 5-1, Table 5-1). Copies of wetland field data sheets used to document site conditions and delineate jurisdictional wetland boundaries at the sites are located in Appendix B. Nine sites lacked one or more of the three field indicators needed to be considered jurisdictional wetlands.

All 16 sites which may be considered jurisdictional wetlands had field indicators of hydrophytic vegetation (Table 5-1), suggesting that the sizes of the jurisdictional wetlands increase slightly with increased seepage and water flow. During years of abundant seepage, wetland vegetation increases in area of coverage, and during years of reduced seepage, the total wetland area is reduced. Four sites have cave pools which contain water throughout most of the year but lack vegetation (Cane, Tippipah, Tub, and Whiterock springs), apparently because of reduced light reaching the caves. These pools that lacked hydrophytic vegetation did not meet the criteria to be considered jurisdictional wetlands but may be considered waters of the United States which still fall under the jurisdiction of the USACE. Yucca Playa Pond is an ephemeral pond, the margins of which support wetland vegetation. However, the pond periodically inundates a large area of about $16,246 \mathrm{~m}^{2}\left(174,807 \mathrm{ft}^{2}\right)$ which appears to support no vegetation. Like the unvegetated cave pools, this area may also be considered waters of the United States.

Twenty-three of the 25 study sites had field indicators of wetland hydrology (Table 5-1). No such field indicators were found at Rainier Spring and Tupapa Seep when these sites were visited (Table 5-1). The source of water at most of the study sites is groundwater discharge from seeps and springs. Surface runoff from precipitation was found at Yucca Playa Pond and at four sites with natural rock catchment basins (tanks). The length of time soils are saturated at these sites which retain surface runoff varies depending on the time of year when precipitation events occur. Winter storms provide water that stays longer in the tanks and pond than water from summer storms. Two sites have tanks (Rock Valley Tank and Yellow Rock Springs), but they also have some water from seepage. Little is known about the persistence of water in all of the known NTS tanks through the year, but it is possible that water in these natural rock depressions, as well as in Yucca Playa Pond, would be considered waters of the United States by the USACE.

Twenty sites were observed to have field indicators for hydric soils (Table 5-1). Field indicators were limited at these sites and were often inferred from site hydrology and past observations of surface water or saturated soils. The five sites lacking field indicators for hydric soils either had no water or no saturated soils at the time the survey was conducted (Pavits Spring, Rainier Spring, Rock Valley Tank, and Tupapa Seep) or were located in bedrock and soils were absent (Tongue Wash Tank). The soils at the remaining 20 sites often lacked field indicators such as mottling and low chroma values (i.e., dark colored soils due to high organic matter content) that are common in wetter climates such as the Great Basin. Desert wetland soils on the NTS are often subject to severe erosion during 


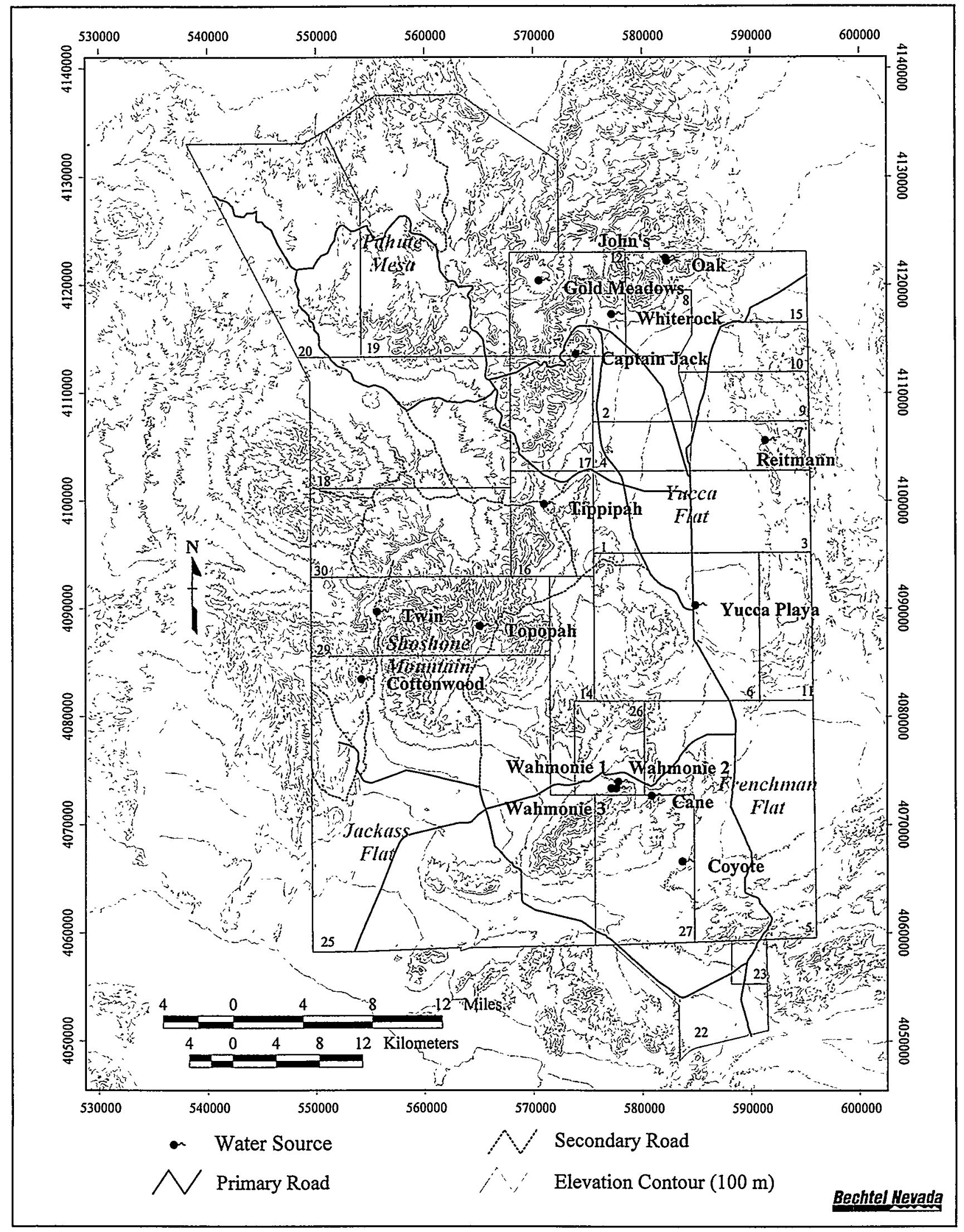

Figure 5-1 Water sources identified as jurisdictional wetlands at the NTS 
Table 5-1 Wetland hydrology data and jurisdictional wetland status of natural water sources surveyed June 1996 - February 1997

\begin{tabular}{|c|c|c|c|c|c|c|c|c|}
\hline Water Source & $\begin{array}{c}\text { Area of } \\
\text { Wetland } \\
\text { Vegetation } \\
\left(\mathrm{m}^{2}\right)^{2}\end{array}$ & $\begin{array}{c}\text { Area of } \\
\text { Surface } \\
\text { Water } \\
\left(\mathrm{m}^{2}\right)^{b}\end{array}$ & $\begin{array}{c}\text { Flow } \\
\text { Rate } \\
(\ell / \mathrm{min})^{\mathrm{c}}\end{array}$ & $\begin{array}{l}\text { Maximum } \\
\text { Depth } \\
\text { (cm) }\end{array}$ & Vegetation & nd Indicators & Soils & $\begin{array}{l}\text { Jurisdictional } \\
\text { Statuse }^{\mathbf{s}}\end{array}$ \\
\hline Ammonia Tanks & 0 & 30 & 0 & 100 & no & yes & yes & no \\
\hline Cane Spring & 230 & 4 & 3.0 & 200 & yes & yes & yes & yes \\
\hline Captain Jack Spring & 30 & 7 & 0.9 & 18 & yes & yes & yes & yes \\
\hline Cottonwood Spring & 130 & 90 & 1.0 & 25 & yes & yes & yes & yes \\
\hline Coyote Spring & 160 & 0 & 0 & 0 & yes & yes & yes & yes \\
\hline Fortymile Canyon Tanks & 0 & 8 & 0.2 & 20 & no & yes & yes & no \\
\hline Gold Meadows Spring & 45 & 0 & 0 & 0 & yes & yes & yes & yes \\
\hline John's Spring & 50 & 5 & 0.4 & 3 & yes & yes & yes & yes \\
\hline Oak Spring & 40 & 1 & 0.4 & 3 & yes & yes & yes & yes \\
\hline Pavits Spring & 0 & 0 & 0 & 0 & no & yes & no & no \\
\hline Rainier Spring & 0 & 0 & 0 & 0 & no & no & no & no \\
\hline Reitmann Seep & 1 & 1.5 & 0.2 & 15 & yes & yes & yes & yes \\
\hline Rock Valley Tank & 0 & 0.1 & 0. & 30 & no & yes & no & no \\
\hline Tippipah Spring & 500 & 190 & 2.7 & 38 & yes & yes & yes & yes \\
\hline Tongue Wash Tank & 0 & 4.5 & 0 & 25 & no & yes. & no & no \\
\hline Topopah Spring & 200 & 8 & 0.12 & 25 & yes & yes & yes & yes \\
\hline Tub Spring & 0 & 0.1 & 0.1 & 5 & no & yes & yes & no \\
\hline Tupapa Seep & 0 & 0 & 0 & 0 & no & no & no & no \\
\hline Twin Spring & 27 & 2 & NM & 10 & yes & yes & yes & yes \\
\hline Wahmonie Seep 1 & 250 & 5 & NM & 8 & yes & yes & yes & yes \\
\hline Wahmonie Seep 2 & 150 & 0.25 & 0 & 0 & yes & yes & yes & yes \\
\hline Wahmonie Seep 3 & 180 & 0 & 0 & 0 & yes & yes & yes & yes \\
\hline Whiterock Spring & 1,800 & 0.1 & 1.9 & 3 & yes & yes & yes & yes \\
\hline Yellow rock Spring & 0 & 30 & NM & 40 & yes & yes & yes & yes \\
\hline Yucca Playa Pond & $3,400^{\mathrm{f}}$ & 22,930 & 0 & 150 & yes & yes & yes & yes \\
\hline Total Area $\left(\mathrm{m}^{2}\right)$ & 7,193 & 23.316 & & & & & & \\
\hline
\end{tabular}

${ }^{\text {T}}$ Total surface area over which wetland plans were located. 'Maximum inundated area recorded at the time of the survey. $\mathrm{c}$ Maximum flow rate recorded during the year 1996. NM = maximum depth of natural surface water pools. 'Whether site qualifies as a

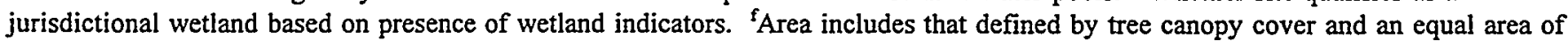
extended roots. 
storm runoff that removes soil from its place of accumulation. The drying of the remaining soil during periods of low precipitation does not permit the accumulation of organic matter (low chroma) or the presence of other characteristics (mottling) common to hydric soils elsewhere. Desert soils do, however, meet the criteria of hydric soils when they are inundated for long (seven days to one month) or very long (greater than 30 days) periods of time during the plant growing season.

\subsection{Physical and Chemical Features}

\subsubsection{Physical Hydrology}

Twenty-five sites were visited and characterized between June 1996 and January 1997. Eleven of these wetlands have surface flow of water all year long (Cane Spring, Captain Jack Spring, Cottonwood Spring, John's Spring, Oak Spring, Reitmann Seep, Tippipah Spring, Topopah Spring, Tub Spring, Twin Spring, and Whiterock Spring). The remaining 14 sites are ephemeral; they may dry up at some period of time during the year or during dry years. The sizes of the NTS wetlands are very small compared to the Ash Meadows spring system. With the exception of Tippipah Spring, Whiterock Spring, and Yucca Playa Pond, most of the sites were relatively small in size, less than $300 \mathrm{~m}^{2}$ $\left(3,228 \mathrm{ft}^{2}\right)$ (Table 5-1). The NTS wetlands varied in size from less than $1 \mathrm{~m}^{2}\left(10.8 \mathrm{ft}^{2}\right)$ to approximately $3,400 \mathrm{~m}^{2}\left(37,000 \mathrm{ft}^{2}\right)$ based on the area of hydrophytic vegetation. Yucca Playa Pond and Whiterock Spring had the largest area of wetland vegetation at $1,800 \mathrm{~m}^{2}$ $\left(19,368 \mathrm{ft}^{2}\right)$ and $3,400 \mathrm{~m}^{2}\left(37,000 \mathrm{ft}^{2}\right)$, respectively. Inundated areas were also very small $\left(1 \mathrm{~m}^{2}\left[10.8 \mathrm{ft}^{2}\right]\right.$ to about $\left.190 \mathrm{~m}^{2}\left[2,045 \mathrm{ft}^{2}\right]\right)$ except for the Yucca Playa Pond $\left(22,932 \mathrm{~m}^{2}\right.$ $\left.\left[246,748 \mathrm{ft}^{2}\right]\right)$, which had more surface water than all the other sites combined. When these sites are inundated, water levels are generally very shallow, ranging from 3 to $200 \mathrm{~cm}$ (1.2 to $78.8 \mathrm{in}$ ) (Table $5-1$ ).

Flow rates of NTS springs measured in 1996 and 1997 were very low, ranging from 0.0 to $3.0 \mathrm{\ell} / \mathrm{min}(0.0$ to $0.80 \mathrm{gal} / \mathrm{min})$, while the flow rate at Crystal Springs in Ash Meadows is over $9,500 \mathrm{\ell} / \mathrm{min}(2,500 \mathrm{gal} / \mathrm{min}$ ) (DOE, 1988). Flow rates of springs at NTS vary seasonally and are partially dependent on large precipitation events (Ingraham et al., 1991; Lyles et al., 1990). For example, at Cane Spring, surface flow from the cave pool was negligible during June 1996, but was measured at approximately $3 \mathrm{l} / \mathrm{min}(0.8 \mathrm{gal} / \mathrm{min})$ during November 1996 following a period of local rainfall. A review of historical flow rates of NTS springs suggests that discharge rates measured in 1996 fall within the range of most previously reported discharge rates from 1982 to 1990 . This is not the case, however, when current flow rates are compared with those from the 1960 s. There is one historical record which suggests that flow rates have decreased markedly over the last 25 years at two of the largest NTS springs. In November 1960, Moore (1961) reported discharge rates at Cane Spring of 7.6 to $11.4 \mathrm{\ell} / \mathrm{min}$ (2 to $3 \mathrm{gal} / \mathrm{min}$ ) and at Whiterock Spring of 3.8 to $7.6 \mathrm{\ell} / \mathrm{min}$ (1 to $2 \mathrm{gal} / \mathrm{min}$ ). About 25 years later (1981-1988), measurements ranged from 1.1 to $6.3 \mathrm{l} / \mathrm{min}(0.29$ to $1.66 \mathrm{gal} / \mathrm{min})$ for Cane Springs and 0.5 to 4.6 $\ell / \mathrm{min}(0.37$ to $1.22 \mathrm{gal} / \mathrm{min}$ ) for Whiterock Spring (Ingraham et al., 1991; Lyles et al., 1990). Other evidence which suggests declining flow rates at Cane Spring is the area of inundation which has decreased dramatically from 1963 to the present (see Photos 4-5 and 4-6). This reduction probably occurred in the late 1960 s or early 1970 s when a reduction in flow from NTS springs was noted by Giles (1976). 
The earliest accounts of flow rates for springs at NTS are reported by Ball (1907) who indicated that discharges at Oak and Whiterock springs were both approximately " 1500 to 3000 gallons a day" (4 to $8 \mathrm{\ell} / \mathrm{min}$ ). Such rates are well above those reported during 1996; Oak Spring was $0.4 \mathrm{\ell} / \mathrm{min}(0.1 \mathrm{gal} / \mathrm{min})$ and Whiterock Spring was $1.9 \mathrm{\ell} / \mathrm{min}(0.5 \mathrm{gal} /$ min). Data from Ball (1907) showed rates at Cane Spring (4 l/min [about 1,500 gal/day]) that are more consistent with 1980-1996 measured rates, but are half the 1960 values reported by Moore (1961). Similar long-term trends in.spring flow rates are not apparent in the historical data from other NTS springs. For example, discharge at Topopah Spring was slightly lower in 1907 (0.04 to $0.07 \mathrm{\ell} / \mathrm{min}$ [0.01 to $0.02 \mathrm{gal} / \mathrm{min}$ ]) (Ball, 1907) than that recorded in $1996(0.14 \mathrm{\ell} / \mathrm{min} \cdot[0.04 \mathrm{gal} / \mathrm{min}])$ but also less than that recorded in 1960 $(0.5 \mathrm{\ell} / \mathrm{min}[0.13 \mathrm{gal} / \mathrm{min}])$.

These data suggest that the springs on the NTS do not respond similarly through time. Whiterock Spring appears to have been very consistent since the early 1900s, while Oak Spring has declined steadily. Cane and Topopah springs increased in the 1960s from the early 1900 s, but returned to previously recorded rates by the 1980 s and 1990s. It is important to note that there are several factors that could account for changes in documented spring discharges over time, including changes in climate, changes in rock matrix structure due to seismic events, and man-made modifications to the seeps and springs themselves. At Cane Spring, for example, excavation of the tunnel may have exposed water-filled rock fractures that resulted in a short-term increase in spring flow rates, which then decreased through time as the fracture was drained. Different hydrogeologic conditions among the developed springs could explain the variety of responses observed at these sites. Also, the historical data may reflect errors in discharge measurements and seasonal variations not taken into account during the measurement of flow rates.

Nine springs at NTS have been altered in some way by humans to improve flow for various purposes such as mining or ranching activities. These alterations usually involved digging adits and installing pipes and tanks to improve flow or storage capacity. Cane, Oak, Tippipah, Topopah, Tub, Twin, and Whiterock springs have all been excavated. Gold Meadows Spring was improved by constructing an earthen berm to increase water storage. Captain Jack Spring had pipes and watering troughs installed to increase water availability. These alterations have had effects on present conditions of soils, vegetation, and surface hydrology. For example, human activities around springs have caused vegetation changes such as plant introductions, selected grazing of some species, and physical disturbance.

Twenty-three of the 25 study sites discussed in this report demonstrate field indicators for wetland hydrology (Table 5-1). The presence of standing water (inundated soils), however, was limited to 21 of the 25 sites.

\subsubsection{Chemical Features}

Biologically important water quality parameters (water temperature, dissolved oxygen, $\mathrm{pH}$, total dissolved solids, and electrical conductivity) were measured at 11 wetland sites which had surface water exceeding $5 \mathrm{~cm}$ (2 in) in depth (Table 5-2). At three sites (Cane, Tippipah, and Whiterock springs), water quality was sampled at two locations within the 
Table 5-2

Water quality measurements of natural water sources on the NTS surveyed June 1996 - February 1997

\begin{tabular}{|c|c|c|c|c|c|c|c|}
\hline Spring/Seep & Date & $\begin{array}{c}\begin{array}{c}\text { Location } \\
\text { (microhabitat) }\end{array} \\
\end{array}$ & $\begin{array}{l}\text { Water Temperature } \\
\left({ }^{\circ} \mathrm{C}\right)\end{array}$ & $\begin{array}{c}\text { Dissolved } \\
\text { Oxygen (ppm) }\end{array}$ & $\mathrm{pH}$ & TDS (ppm) & $\begin{array}{c}\text { Electrical } \\
\text { Conductivity }(\mu \mathrm{S})\end{array}$ \\
\hline $\begin{array}{l}\text { Canc } \\
\text { Cane } \\
\text { Canc } \\
\text { Cane } \\
\text { Cance } \\
\text { Cane }\end{array}$ & $\begin{array}{l}6 / 19 / 96 \\
9 / 09 / 96 \\
11 / 13 / 96 \\
6 / 19 / 96 \\
0 / 09 / 96 \\
11 / 13 / 96\end{array}$ & $\begin{array}{l}\text { cave pool } \\
\text { cave pool } \\
\text { cave pool } \\
\text { flow box } \\
\text { flow box } \\
\text { flow box }\end{array}$ & $\begin{array}{l}19.4^{*} \\
17.4 \\
15.7 \\
28.0^{*} \\
22.2 \\
9.2 \\
\end{array}$ & $\begin{array}{l}6.2^{*} \\
6.0 \\
8.4 \\
0.7^{*} \\
2.6 \\
6.7 \\
\end{array}$ & $\begin{array}{l}7.7^{*} \\
7.1 \\
7.2 \\
7.3^{*} \\
7.0 \\
7.3 \\
\end{array}$ & $\begin{array}{l}190^{*} \\
207 \\
209 \\
248^{*} \\
227 \\
256\end{array}$ & $\begin{array}{l}\overline{406} \\
424 \\
- \\
453 \\
525\end{array}$ \\
\hline $\begin{array}{l}\text { Captain Jack } \\
\text { Captain Jack }\end{array}$ & $\begin{array}{l}6 / 19 / 96 \\
9 / 10 / 96\end{array}$ & $\begin{array}{l}\text { spring pool } \\
\text { spring pool }\end{array}$ & $\begin{array}{l}19.0^{*} \\
16.8\end{array}$ & $\begin{array}{l}5.5^{*} \\
4.9\end{array}$ & $\begin{array}{l}7.1^{*} \\
7.3\end{array}$ & $\begin{array}{l}90^{*} \\
95\end{array}$ & $\overline{193}$ \\
\hline $\begin{array}{l}\text { Reitmann } \\
\text { Reitmann } \\
\text { Reitmann } \\
\text { Reitmann }\end{array}$ & $\begin{array}{l}6 / 19 / 96 \\
7 / 24 / 96 \\
9 / 10 / 96 \\
11 / 22 / 96 \\
\end{array}$ & $\begin{array}{l}\text { spring pool } \\
\text { spring pool } \\
\text { spring pool } \\
\text { spring pool }\end{array}$ & $\begin{array}{l}30.0^{*} \\
28.4 \\
31.5 \\
12.4 \\
\end{array}$ & $\begin{array}{l}- \\
2.1 \\
8.1 \\
2.7\end{array}$ & $\begin{array}{l}9.2^{*} \\
7.7 \\
8.8 \\
7.4\end{array}$ & $\begin{array}{l}379^{*} \\
346 \\
336 \\
287 \\
\end{array}$ & $\begin{array}{l}\overline{-} \\
669 \\
557\end{array}$ \\
\hline $\begin{array}{l}\text { Tippipah } \\
\text { Tippipah } \\
\text { Tippipah } \\
\text { Tippipah } \\
\text { Tippipah } \\
\end{array}$ & $\begin{array}{l}6 / 18 / 96 \\
9 / 03 / 96 \\
11 / 15 / 96 \\
9 / 03 / 96 \\
11 / 22 / 96 \\
\end{array}$ & $\begin{array}{l}\text { open channel pool } \\
\text { open channel pool } \\
\text { open channel pool } \\
\text { cave pool } \\
\text { cave pool }\end{array}$ & $\begin{array}{l}18.6^{*} \\
18.5 \\
13.7 \\
15.3 \\
14.3\end{array}$ & $\begin{array}{l}1.2 \\
1.0 \\
4.6 \\
6.7 \\
7.8\end{array}$ & $\begin{array}{l}6.8 \\
6.7 \\
7.2 \\
7.0 \\
7.1 \\
\end{array}$ & $\begin{array}{l}114 \\
135 \\
119 \\
114 \\
106 \\
\end{array}$ & $\begin{array}{l}\overline{267} \\
243 \\
227 \\
212 \\
\end{array}$ \\
\hline $\begin{array}{l}\text { Tub } \\
\text { Tub }\end{array}$ & $\begin{array}{l}6 / 24 / 96 \\
9 / 10 / 96\end{array}$ & $\begin{array}{l}\text { guzzler can } \\
\text { guzzler can }\end{array}$ & $\begin{array}{l}26.0^{*} \\
26.5 \\
\end{array}$ & $\overline{6.0}$ & $\begin{array}{l}7.6 \\
7.5\end{array}$ & $\begin{array}{l}147 \\
146\end{array}$ & $\overrightarrow{294}$ \\
\hline Twin & $1 / 08 / 97$ & spring pool & 16.8 & 1.0 & 7.0 & 137 & 271 \\
\hline Wahmonie Seep 1 & $6 / 20 / 96$ & wash pool & $17.8^{*}$ & 1.8 & $7.5^{*}$ & 259 & - \\
\hline $\begin{array}{l}\text { Whiterock } \\
\text { Whiterock } \\
\text { Whiterock }\end{array}$ & $\begin{array}{l}6 / 18 / 96 \\
9 / 03 / 96 \\
9 / 03 / 96\end{array}$ & $\begin{array}{l}\text { flow box' } \\
\text { flow box } \\
\text { west cave pool }\end{array}$ & $\begin{array}{l}16.8 \\
18.7 \\
15.6 \\
\end{array}$ & $\begin{array}{l}8.1^{*} \\
6.6 \\
5.8\end{array}$ & $\begin{array}{l}7.0 \\
7.2 \\
7.4 \\
\end{array}$ & $\begin{array}{l}124 \\
139 \\
142 \\
\end{array}$ & $\begin{array}{l}\overline{277} \\
276\end{array}$ \\
\hline Yucca Playa & $1 / 07 / 97$ & pond & 1.7 & 13.6 & 8.1 & 162 & 328 \\
\hline
\end{tabular}

*Values represent single readings. All other values are an average of three readings. "-" indicates no data collected. 
wetland to assess potential differences in biological indicators in different microhabitats (Table 5-2). Although the data set is small, two biologically important parameters, water temperature and dissolved oxygen, showed differences between and within microhabitats across season. Temperatures were consistently lower in the cave pools at these three sites, ranging from $3^{\circ} \mathrm{C}$ to $9^{\circ} \mathrm{C}\left(5^{\circ} \mathrm{F}\right.$ to $\left.15^{\circ} \mathrm{F}\right)$ less than the temperatures recorded in the open pools at these sites. Among all sites, water temperatures ranged from a low of $1.7^{\circ} \mathrm{C}$ $\left(35^{\circ} \mathrm{F}\right)$ in a January 1997 sample beneath the ice at Yucca Playa Pond, to a high of $31.5^{\circ}$ $\mathrm{C}\left(88^{\circ} \mathrm{F}\right)$ at Reitmann Seep in September 1996. Water temperatures measured at NTS springs are consistent with those from perched groundwater springs which are generally less than $21^{\circ} \mathrm{C}\left(70^{\circ} \mathrm{F}\right)$ (Winograd and Thordarson, 1975). Water in pools at the springs is subject to solar heating and is not geothermally heated as is common in many springs in the Mojave Desert, including Ash Meadows.

For the 11 water sources at which data were collected, the dissolved oxygen values ranged from a low of 1.0 at Tippipah Spring in September 1996 to a high of 13.6 in the Yucca Playa Pond in January 1997. Dissolved oxygen is inversely correlated with water temperature; thus, it shows seasonal fluctuations with higher values in winter and lower values in late summer. Dissolved oxygen readings also were higher in the cave pools versus the surface outflows at Cane, Tippipah, and Whiterock springs. The higher decomposition rates (increased biological oxygen demand) and higher water temperatures in the outside pools contribute to these differences. These water quality parameters are important for aquatic organisms such as the hydrobiid snail at Cane Spring. The snail appears to require water of lower temperature and higher oxygenation for survival. Its absence from the flow box microhabitat was coincident with low flow into the box and the higher temperature/lower oxygen measurements taken in June and September, 1996.

Values for $\mathrm{pH}$ were fairly constant for most sites across the sampling dates (Table 5-2). Most sites had slightly basic $\mathrm{pH}$ values which is in close agreement with values recorded by Lyles et al. (1990). They sampled six springs on the NTS and found means ranging from 7.09 to 7.65. In addition, $\mathrm{pH}$ values from selected springs measured by Moore (1961) are similar in most cases to measurements taken in 1996, although readings from Cane and Tippipah springs were more alkaline. These values differ from those obtained by Taylor and Giles (1979) who reported that seven of eight NTS springs monitored had slightly acidic water.

Total dissolved solids and electrical conductivity measured at NTS springs in 1996 (Table 5-2) appear within similar ranges of previously reported values (Moore, 1961; Lyles et al., 1990). Total dissolved solids were fairly constant across season and were generally low (66 to 379 parts per million [ppm]) when compared to irrigation water standards $600 \mathrm{ppm}$ (U.S. Salinity Laboratory, 1954). Topopah Spring had the lowest values, while Reitmann Seep had the highest values. Data collected by others on major cations, anions, and mineral and trace elements in NTS spring water suggest that the water chemistry of NTS springs has not changed greatly over the past 35 years (Moore, 1961; Taylor and Giles, 1979; Romney and Greger, 1994; Lyles et al., 1990; Stetzenbach, 1994). 


\subsection{Biological Features}

\subsubsection{Wetland Plants}

Eighty-one species of vascular plants have been recorded in or near wetland sites on the NTS (Table 5-3). There are relatively fewer species of plants recorded at all NTS wetland sites compared to other wetlands in southern Nevada such as Ash Meadows, where approximately 327 species of plants have been identified (The Nature Conservancy and FWS, 1996). Most of the species in NTS wetlands are forbs (34 species, 42 percent) followed by grasses/rushes/sedges ( 29 species, 36 percent), and trees/shrubs (18 species, 22 percent). This is very different from the general flora of the NTS, where forbs make up approximately 74 percent of the total number of species. Grasses, rushes, and sedges make up only 12 percent, while trees/shrubs make up 14 percent (Beatley, 1976).

The total number of plant species recorded at each wetland site during 1996 varied between 0 and 25. Cane, Topopah, Tippipah, and Whiterock springs had the most species recorded $(25,24,23$, and 22 respectively) (Table 5-3). Tongue Wash Tank had no plant species recorded in the observation area. Three sites, Gold Meadows Spring, Rainier Spring, and Rock Valley Tank had only one species. Low species numbers at sites are due primarily to the rocky nature and lack of soil moisture at these sites. In general, the smaller, ephemeral wetlands had fewer species, while the larger more permanent wetlands had more species (Tables 5-1 and 5-3). Thirty-six species of plants occurred at only a single wetland site, while others (e.g., basin wildrye, Louisiana sagewort, Baltic rush, annual rabbitsfoot grass, and seep monkeyflower) had much wider distributions (Table 5-3).

Overall, there are 24 species of plants at NTS wetlands that had 10 percent or greater absolute cover (classified as dominants) (Table 5-3). Half of these dominants (12 species) are grasses, rushes, or sedges. Forbs, which include more species than the other plant groups, have only five species that are dominants, while trees and shrubs comprised seven dominant species. These dominant species are very important in determining if hydrophytic vegetation is present at a site. Seventeen of the 24 dominant species are listed as obligate or facultative wetland species. They typify wetland areas because they generally do not occur outside very wet habitats. Three dominant species (basin wildrye, Sandberg bluegrass, and Louisiana sagewort) found in NTS wetlands are listed as facultative upland species. Species in this category can tolerate moist conditions but are more typically found in drier upland habitats. On the NTS, however, these three species are found primarily in spring areas, washes, and other areas where moisture is abundant and should probably be listed as facultative wetland species for southern Nevada. The brome grasses, foxtail brome and cheatgrass, were dominants at one or more study sites. They are ubiquitous on disturbed sites. Foxtail brome is listed as an upland species, cheatgrass, is not listed on the Region 8 species list, and they and are not indicators of mesic habitats on the NTS. There are two other dominants which were recorded at several study sites: 


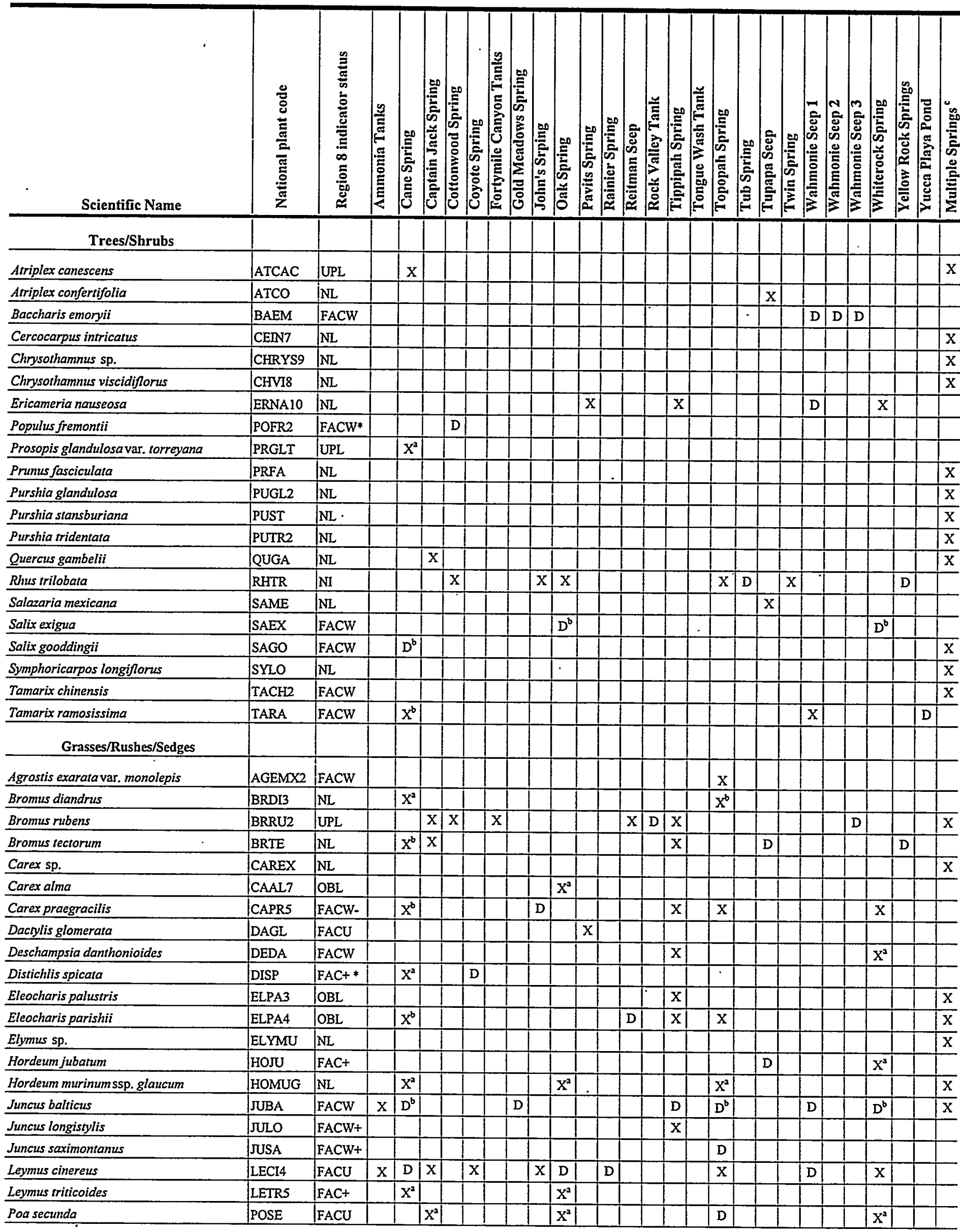




\begin{tabular}{|c|c|c|c|c|c|c|c|c|c|c|c|c|c|c|c|c|c|c|c|c|c|c|c|c|c|}
\hline Scientific Name & 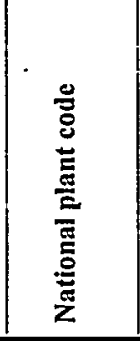 & 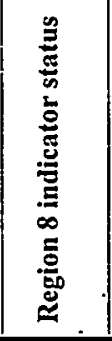 & 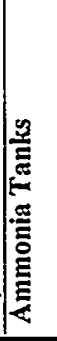 & 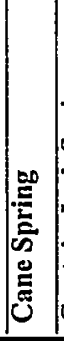 & 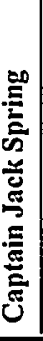 & 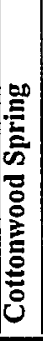 & 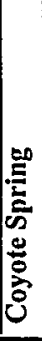 & 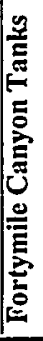 & 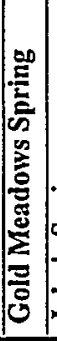 & & & 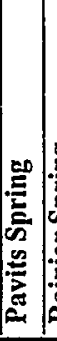 & & 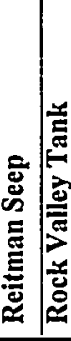 & 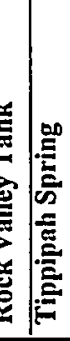 & 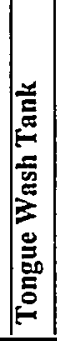 & & & 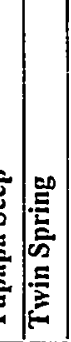 & 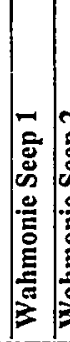 & 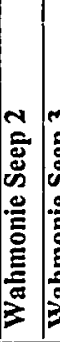 & & & 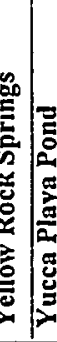 & 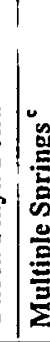 \\
\hline Polypogon interruptus & POIN7 & FACW+ & & & & & & & & & & & & & & & & & 1 & & & & 1 & & $\mathrm{Tx}$ \\
\hline Polypogon monspeliensis & POMO5 & $\mathrm{FACW}+$ & & $x^{b}$ & & & & & & & & & & $\mathrm{D}$ & $D$ & & $\mathrm{x}$ & & $\mathrm{x}$ & $|x|$ & & & $x^{6}$ & & $\mathrm{X}$ \\
\hline Polypogon viridis & POVI9 & $\mathrm{OBL}$ & & $x^{2}$ & & & & & & & $\mathrm{x}^{2}$ & & & & & & & & & & & & & & $\mathrm{x}$ \\
\hline Potamogeton pectinatus & POPE6 & OBL & & $x^{3}$ & & & & & & & & & & & & & & & & & & & & & \\
\hline Sporobolus airoides & SPAI & FAC- & & & & & & & & & & $\mathrm{x} \mid$ & & & & & & & & & & & & & \\
\hline Typha domingensis & TYDO & $\mathrm{OBL}$ & & $\mathrm{X}^{b}$ & & & & & & & & & & & $x$ & & & & $\mathrm{D}$ & & & & $\mathrm{X}$ & 18 & $x$ \\
\hline Typha latifolia & TYLA & OBBL & & & & & & & & & & & & & & & & & & & & & $x^{3}$ & & 1 \\
\hline Unidentified grass & & $\mathrm{NL}$ & & & & & & & & & & & & & & & & $\mathrm{x}$ & & & & & & & 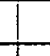 \\
\hline Forbs & & & & & & & & & & & & & & & & & & & & 1 & & & & 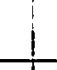 & \\
\hline Amaranthus albus & AMAL & FACU & & $x^{a}$ & & & & & & & & & & & $x^{2}$ & & & & & & & & $x^{2}$ & & $x$ \\
\hline Artemisia dracunculus & ARDR4 & $\mathrm{NL}$ & & & & $\mathrm{x}$ & & & & & & & & & & & & & $\mathrm{x}$ & & & 1 & & & - \\
\hline Artemisia ludoviciana & ARLU & FACU & D & & $\mathrm{x}$ & $\mathrm{x}$ & & $x$ & & & & & & & $\mathrm{x}$ & & $\mathrm{D}$ & & $\mathrm{x}$ & $\mathrm{x}$ & $\mathrm{x} \mid$ & \begin{tabular}{l|l}
$\mathrm{D}$ & $:$ \\
\end{tabular} & $x$ & & 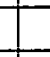 \\
\hline Berula erecta & BEER & $\mathrm{OBL}$ & & $x^{2}$ & & & - & 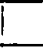 & & & & & & & & & & & & & & & & & $\mathrm{x}$ \\
\hline Camissonia megalantha & CAME16 & $\mathrm{NL}$ & & $\mathrm{x}^{2}$ & & & & & & & & & & & & & & & & & & & & & $\mathrm{x}$ \\
\hline Castilleja applegatei ssp. martinii & CAAMP & $\mathrm{NL}$ & & & & & & & & & & & & & $\mathrm{x}$ & & $\mathrm{x}^{2}$ & & & & & & & & \\
\hline Cirsium neomexicanum & CINE & $\mathrm{NL}$ & & & & $\mathrm{x}$ & & & & 1 & & & & & & & & & & & & & & & \\
\hline Cleome lutea & CLLU2 & UPL & & $x^{2}$ & & & & & & 1 & & & & & & & & & & & & $i$ & & & $\mathrm{x}$ \\
\hline Conyza canadensis & COCA5 & FACU & & & & & & & & & & & & & & & $\mathrm{x}$ & & & 1 & & & $x^{b}$ & & \\
\hline Encelia sp. & ENCEL & $\mathrm{NL}$ & $\mathrm{x}$ & & & & & & & & & & & & & & & & & & & & & & 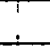 \\
\hline Epilobium ciliatum & EPCI & FAC & & & & & & & & & & & & & & & & & & & & & $\mathrm{x}^{2}$ & & $!$ \\
\hline Epilobium glaberrimum & EPGL & FACW & & & & & & & & & & & & & $x$ & & $\mathrm{x}$ & & & & & & . & & 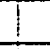 \\
\hline Erigeron divergens & ERD14 & $\mathrm{NL}$ & & & & & & & & 1 & & & & & -1 & & $\mathrm{x}$ & & & & & & $x^{3}$ & & 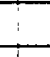 \\
\hline Erodium cicutarium & ERCI6 & $\mathrm{NL}$ & & & & & & & & & & & & & $\mathrm{x}$ & & & & & & & & & & 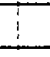 \\
\hline Galium aparine & GAAP2 & FACU & & & & & & & & $x$ & & & & & & & $x^{3}$ & & & & & & & & 1 \\
\hline Heliomeris multiflora var. nevadensis & HEMUN & $\mathrm{NL}$ & & & & & & & & & & & & & $x$ & & & & & & & & & & 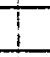 \\
\hline Kochia scoparia & KOSC & FACU & & & & & $\mathrm{x}$ & & & & & & & & & & & & & & & & & & 1 \\
\hline Lactuca serriola & LASE & FACU & & & & & & & & & & & & & $\mathrm{x}$ & & $\mathrm{x}$ & & & 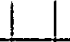 & & & $x^{2}$ & & - \\
\hline Linum lewisii & LILE3 & $\mathrm{NL}$ & & & & & & & & & & & & & 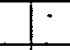 & & & & & & & & $\mathrm{x}$ & & \\
\hline Lotus sp. & LOTUS & $\mathrm{NL}$ & & & & & & & & & & & & & $\mathrm{x}$ & & & & & & & & 4 & & \\
\hline Melilotus indicus & MEIN2 & FACU & & & & & & & & & & & & & & & & & & & & & $\mathrm{x}$ & & \\
\hline Mimulus guttatus & MIGU & $\mathrm{OBL}$ & & $x^{2}$ & $\mathrm{D}$ & $\mathrm{x}$ & & $\mathrm{x}$ & & D) & $\mathrm{x}^{2}$ & & & & $x^{2}$ & & $\mathrm{x}$ & & & $\mathrm{x}$ & & & $\mathrm{x}^{2}$ & & $\mathrm{x}$ \\
\hline Oenothera cespitosa ssp. marginata & OECEM4 & $\mathrm{NL}$ & & & & & & & & $x$ & & & & & & & & & & & & & & & \\
\hline Penstemon rostriflorus & PER010 & $\mathrm{NL}$ & & & $\mathrm{x}$ & & & & & & & & & & & & & & & & & & & & \\
\hline Penstemon sp. & PENSTEM & $\mathrm{NL}$ & & & & & & & & $\mathrm{x}$ & & & & & & & & & & & & & & & \\
\hline Pentagrama triangularis & PETR7 & $\mathrm{NL}$ & & & & $x$ & & & & & & & & & & & & & & & & & & & \\
\hline Potentilla biennis & POBI7 & FAC & & & $\mathrm{x}$ & & & & & & & & & $\mathrm{x} \mid$ & D & & $\mathrm{x}$ & & 1 & & & & $x^{8}$ & & \\
\hline Pseudognaphalium stramineum & PSST7 & FAC & & & & & & & & & & & & & & & $\mathrm{x}$ & & $L$ & & & & 1 & & \\
\hline Rumex crispus & RUCR & FAC & & $x^{2}$ & & & & & & & & & & & & & & & & & & & & & $x$ \\
\hline Rumex salicifolius & RUSA & FACW* & & $\mathrm{D}$ & $\mathrm{D}$ & & & & & & & & & & & & $\mathrm{D}$ & & $\mathrm{x}$ & & & & $x^{6}$ & & $x$ \\
\hline Sisymbrium altissimum & SIAL2 & FACU- & & & & & & & & & & & & & & & $\mathrm{x}$ & & & & & & & & \\
\hline Suaeda moquinii & SuMo & FACW-* & & & & & & & & & & & & & & & & & & & & & & & $x$ \\
\hline Verbena bracteata & VEBR & FACU & & $\mathrm{X}^{\mathrm{a}}$ & & & & & & & & & & & $\mathrm{x}$ & & & & & & & & & & $x$ \\
\hline Veronica anagallis-aquatica & VEAN2 & $\mathrm{OBL}$ & & $\mid x^{6}$ & $D$ & & & & & & & & & & $\mathrm{D}$ & & D & & & $D$ & & & & & $x$ \\
\hline Total Number of Species & & & 4 & 26 & 11 & 8 & 3 & 3 & 1 & 7 & 9 & 3 & 1 & 4 & $1 \mid 23$ & $3 \mid 0$ & 24 & 2 & \begin{tabular}{|l|l|}
2 & 6 \\
\end{tabular} & 9 & $2 \mid$ & 3 & 22 & 2 & 23 \\
\hline
\end{tabular}

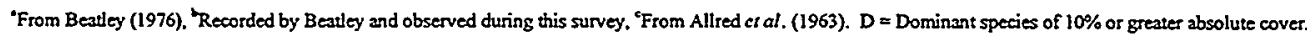


skunkbush sumac, for which the USACE does not have sufficient information about habitat requirements and rubber rabbitbrush, which is not included in the Region 8 species list (Reed, 1996).

Sixteen of the 25 sites characterized on the NTS show field indicators for hydrophytic vegetation.

There are no known plant species on the NTS that are listed as threatened or endangered under the Endangered Species Act. There is, however, one endangered and three threatened plant species that occur in either riparian areas, meadows, seeps, springs, or sinks of Ash Meadows. None of these plants were observed in the wetland habitats of the NTS.

\subsubsection{Algae at Wetland Sites}

Algae were not studied during 1996, although extensive mats of filamentous algae were noted at Captain Jack, Tippipah, and Cane springs. Filamentous algae at Cane Spring was identified as an important substrate for the hydrobiid snail that exists there. Taylor and Giles (1979) reported that Vaucheria sp., Oedogonium sp., and Microthamnion kuetzingianum formed an extensive algal mat substrate covered with several species of diatoms in the Cane Spring tunnel entrance. The snail was sampled and found only on algal mats at the tunnel entrance.

The primary data available on algae at springs are from Taylor and Giles (1979) and Shields and Drouet (1962). Sixty-four species of algae were identified at eight springs (Appendix B). Most of the species identified were diatoms (Chrysophyta - 33 species). Also represented were green algae (Chlorophyta - 20 species) and blue-green algae (Cyanobacteria - 11 species). Cane Spring had the most species with 27. Only three species of algae were identified from Tippipah Spring cave. Algae from springs on the NTS are little studied to date and the species list developed is certainly underrepresented.

\subsubsection{Wildlife Use}

Wetlands are important habitats for many species of animals. . A total of 138 species of animals have been documented at NTS wetland sites (Appendix D). These species include various classes of animals including mammals, birds, reptiles, and terrestrial insects. The largest group of vertebrates using wetlands are birds (Table 5-4). Throughout the arid west, an extraordinary diversity of bird species depend on wetland habitats (Carothers et al., 1974; Knopf et al., 1988a,b; Dobkin, 1994). Among the 134 species of migratory landbirds that breed regularly in the Great Basin, more than.half are associated primarily with riparian habitats (Dobkin, 1996). Destruction or degradation of wetland habitats is widely viewed as the most important factor in the decline of landbird populations in western North America (Bock et al., 1993; Desante and George, 1994; Ohmart, 1994). For this reason, land management agencies are aware of the importance of protecting and restoring riparian habitats for birds and other wildlife (Warner and Hendrix, 1984). 


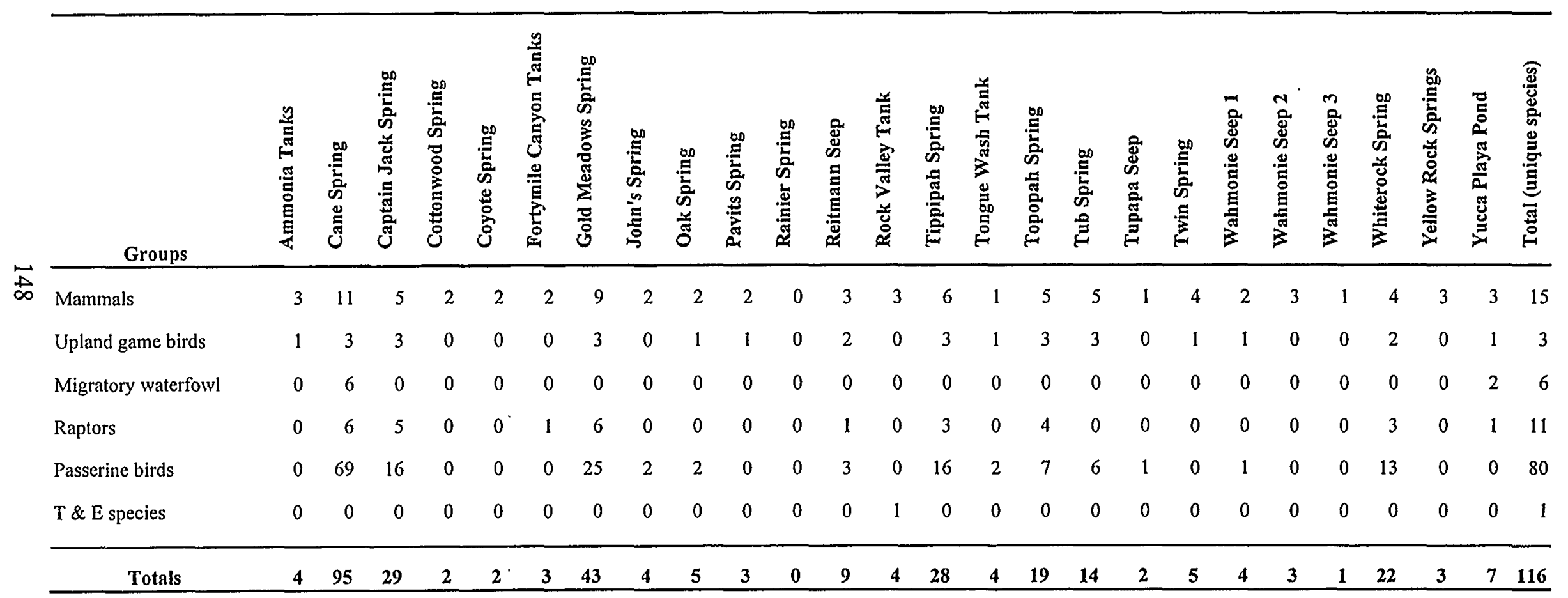


One hundred species of birds have been documented at NTS springs (Table 5-4). Passerine birds comprise the majority of birds recorded (80 species). With the exception of Cane Spring, raptor use appears somewhat higher at higher elevation sites (e.g., Gold Meadows Spring, Captain Jack Spring), although raptor use of wetland habitats has been poorly documented on the NTS. Upland game birds, while few in species number (three: chukar, Gambel's quail, mourning dove), benefit greatly because large numbers of these species depend on food, cover, and water at wetlands for reproduction and survival. Waterfowl use of NTS springs is negligible probably due to the small surface areas of open water. Only Cane Spring and Yucca Playa Pond are natural NTS wetland sites that are known to attract migratory waterfowl.

Mammal use is second in importance in terms of numbers of species, although data deficiencies exist for numerous sites that have been little studied. Fifteen mammal species have been recorded at NTS wetland sites (Table 5-4). It appears from these limited data that not all natural water sources are of equal importance to large mammals. For example, coyotes and mule deer use most of the NTS springs and seeps, while feral horses and. pronghorn antelope use a very limited number of these natural water sources

(Appendix D). This likely reflects the distribution and movement patterns of these species on the NTS. The use and importance of NTS wetlands to small mammals and bats cannot be assessed without further studies.

Documented use of wetland habitats on the NTS by federally listed endangered or threatened species appears to be negligible. There are only three such wildlife species known to occur on the NTS: the endangered peregrine falcon, and the threatened desert tortoise and bald eagle. Desert tortoise scat has been observed at the Rock Valley Tank (Table 5-4). Peregrine falcons have been sighted at two man-made well reservoirs on the NTS, but not at any natural wetlands (Greger, 1994; Greger, unpublished data). Bald eagles were sighted several times near Rock Valley during February 1977 (Castetter and Hill, 1979).

Cane Spring has the heaviest recorded species use (95 species) of all wetland sites (Table 5-4), due in part to the fact that the area has been more intensively studied and that a pond, which existed at the site when discharge rates were higher, probably attracted more bird species, particularly migratory waterfowl and passerine birds. Gold Meadows Spring, Captain Jack Spring, and Tippipah Spring also support fair numbers of species $(44,29,26$, respectively). There are several study sites that show very low numbers of species (Cottonwood Spring, Coyote Spring, Fortymile Canyon Tanks, Rainier Spring, Tupapa Seep, and Wahmonie Seep 3). All of these sites (except Cottonwood Spring) have only ephemeral water that is unavailable for wildlife use much of the year. These low numbers of species recorded may be a result of very limited study (particularly for Cottonwood Spring) and may underestimate their importance to wildlife.

Many aquatic invertebrate organisms occur in NTS springs despite their small surface area. Observed groups of aquatic organisms in springs include oligochaetes (segmented worms), nematodes (roundworms), copepods, ostracods (seed shrimps), cladocerans (water fleas), chironomids (midge larvae), and hydrobiid gastropods (springsnails); and Yucca Playa Pond is known to support three species of shrimp (fairy, tadpole, and clam shrimp) (Starkweather, 1995). The one species of hydrobiid snail (Pyrgulopsis sp.) is now 
restricted to a small area of the spring cave pool at Cane Spring. This organism also occurs in four springs located in the northern region of the Spring Mountains some $64 \mathrm{~km}$ $(40 \mathrm{mi})$ south of Cane Spring. Relatively little is known about aquatic invertebrates from riparian habitats in the Great Basin (Hersher and Pratt, 1990). They are also poorly known on the NTS. 


\subsection{MANAGEMENT OF NTS WETLANDS}

The management goals and practices described in this section may be incorporated into the NTS resource management plan. During development of this plan, new wetlands-related goals (in addition to those below) may also be established. They will be integrated with those for other NTS resources such as surface and groundwater, biota, geology, and existing infrastructure. The interests of regional land and wildlife managers and stakeholders will be considered and may be incorporated into new goals. For example, DOE/NV's goal for wetlands preservation may be linked with the Nevada Division of Wildlife's goal to maintain viable populations of chukar that are known to use selected NTS springs. The management goals and practices described below are currently implemented on the NTS and ensure compliance with wetlands legislation and DOE policy to manage the NTS under the guiding principles of ecosystem management.

\subsection{Protection as Important Biological Resources}

Many natural water sources on the NTS provide islands of unique habitat within the Mojave and Great Basin Desert communities of south-central Nevada. Wetlands, by definition, support plants that do not normally grow in unsaturated desert soils, and therefore increase the biodiversity of plant communities on the NTS. Similarly, some NTS wetlands provide rare environments within the region for isolated populations of aquatic organisms. They also attract migratory waterfowl, passerine birds, and game species of wildlife, as documented in this report. For these reasons, and apart from their jurisdictional statis under the CWA, the NT.S wetlands are regarded as rare habitats which are important biological resources. The management goals for all important biological resources on the NTS include (1) avoiding impacts to the resource whenever possible, and (2) minimizing all unavoidable impacts. Additional goals germane to NTS wetlands specifically include restoring the biological integrity of wetlands if degradation occurs and preserving and enhancing the natural and beneficial values of NTS wetlands. These goals combined meet the intent of CWA, NEPA, Executive Order 11990, and the DOE Landand Facility-Use Management Policy.

\subsection{Continued Monitoring}

DOE/NV has conducted periodic surveys of nine NTS natural water sources (Cane, Captain Jack, Gold Meadows, Oak, Tippipah, Topopah, Tub, and Whiterock springs, and Reitmann Seep) since 1989. These surveys have focused on wildlife observations and have served to identify wetland function and values, such as seasonal habitat for migrating water fowl. They are integrated with other ecological monitoring tasks such as surveys to census wild horses and chukar. These surveys will continue, and opportunities will be taken to sample for aquatic organisms and to collect basic water quality data at these sites. Results of continued monitoring of these selected water sources may prove valuable in better understanding the function and value of the NTS wetlands. 


\subsection{Identification and Evaluation of Other NTS Wetlands}

Surveys will continue to be conducted on the NTS to locate other springs, seeps, and playa wetlands. These surveys will be conducted primarily in concert with other ecological monitoring field tasks. The three seeps called Wahmonie Seeps 1, 2, and 3 were discovered in the summer of 1996 during field surveys to map tortoise habitat in the southern one-third of the NTS. Habitat mapping of the northern two-thirds of the NTS is planned for Fiscal Years 1997 and 1998, and it is likely that more wetlands will be found during that effort. To identify all important biological resources on the NTS, biologists will take advantage of all opportunities in the field to visit, describe, sample, and photograph new wetland sites according to the methods described in Section 3.0 of this report. Each new wetland discovered will also be evaluated for its jurisdictional status under the CWA.

\subsection{Maintenance of Wetlands Geospatial Database}

DOE has developed several tools to manage important biological resources, including wetlands, on the NTS. These tools include the EGIS which contains a wetlands geospatial database containing the point locations of all known NTS wetlands linked to field data on vegetation, hydrology, soils, and wildlife usage. Selected digitized photographs of each wetland site are also linked to the database. This database will be updated annually to incorporate all new data collected at known sites or to add data on newly discovered wetland sites. The wetlands geospatial database will eventually be linked with information about other natural and man-made resources for use during implementation of the NTS comprehensive land- and facility-use management plan. These databases will also be used for the preparation of future project-specific EAs and EISs.

\subsection{Inclusion in Project Siting and Permitting Procedures}

Siting procedures for proposed NTS projects include an evaluation of impacts on important biological resources, including wetlands. Projects are redesigned or relocated whenever possible to avoid adverse impacts. It is possible that a proposed NTS project may unavoidably impact a jurisdictional wetland and require a permit under Section 404 of the CWA. The types of activities that require a permit would be those that destroy wetland habitat or alter the discharge, flow, or movement of water through a wetland, which may include

- clearing wetlands if it involves excavating, leveling, filling, or using heavy equipment in the wetlands;

- constructing or improving ditches or berms in wetlands, especially if the ditches or berms alter the flow of water through the wetlands;

- destroying vegetation either physically, mechanically, or chemically (e.g., burning, mowing, or herbicides); and

- dewatering seeps or springs by intercepting ground water.

A limited number of activities are exempted from regulation under Section 404.

Examples of these activities include 
- maintenance of currently serviceable structures such as dikes, dams, bridge abutments, and transportation structures; and

- construction of temporary sediment basins where fill material is not placed into navigable waters.

Much of the site-specific information provided in this report is sufficient to initiate a preapplication consultation with the USACE if an NTS project required a Section 404 permit. 
This Page Intentionally Left Blank 


\subsection{LITERATURE CITED}

Allred, M. D., D E. Beck, and C. D. Jorgensen, 1963. Biotic communities of the Nevada Test Site. Brigham Young University Science Bulletin, Biological Series (2):1-52.

Ball, S. H., 1907. A geological reconnaissance in southwestern Nevada and eastern California. U.S. Geological Survey Bulletin 308, p. 218.

Beatley, J. C., 1976. Vascular plants of the Nevada Test Site and south-central Nevada: ecologic and geographic distributions. TID-26881, p. 308. Available from U.S. National Technical Information Services, Springfield, Virginia.

Bechtel Nevada, 1996. Basic Environmental Compliance and Monitoring Program Fiscal Year 1996 Progress Report, September 27, 1996.

Bock, C. E., V. A. Saab, T. D. Rich, and D. S. Dobkin, 1993. Effects of livestock grazing on neotropical migratory landbirds in western North America. In: D. M. Finch and P. W. Stangel (eds.), Status and management of neotropical migratory birds. USDA Forest Service General Technical Report RM-229, pp. 296-309.

Boyles, B., 1995. Desert wildlife water developments: Questioning use in the Southwest. Wildlife Society Bulletin, Vol 23, No. 4, pp. 663-675.

Carothers, S. W., R. R. Johnson, and S. W. Aitchison, 1974. Population structure and social organization of southwestern riparian birds. American Zoologist 14:97-108.

Castetter, R. C., and H. O. Hill, 1979. Additions to the birds of the Nevada Test Site. Western Birds 10:221-223.

Clebsch, A., Jr., 1960. Ground water in the Oak Spring formation and hydrologic effects of underground nuclear explosions at the Nevada Test Site. U.S. Geological Survey open-file report TEI-759, p. 29.

Cowardin, L., V. Carter, F. Golet, and E. LaRoe, 1979. Classification of wetlands and deep water habitats of the United States. U.S. Fish and Wildlife Service, Report No. F'S/OBS-79/31, p. 103. U.S. Department of Interior, Washington, DC.

Davis, M., B. Dicey, C. Fontana, K.Giles, R. Grossman, P. Huff, B. Hooda, A. Mullen, M. Sells, and C. Wills, 1996. Nevada Test Site Annual Site Environmental Report - Calender Year 1995. DOE/NV/11718. S. C. Black, and Y. E. Townsend (eds.) U.S. Department of Energy/Nevada Operations Office, Las Vegas, Nevada.

Desante, D. F., and T. L. George, 1994. Population trends in the landbirds of western North America. In: J. R. Jehl, Jr., and N. K. Johnson (eds.), A century of avifaunal change in western North America. Studies in Avian Biology, Volume 15, pp. 173-190. 
Dobkin, D. S., 1996. Conservation and management of neotropical migrants landbirds in the Great Basin. University Idaho Press, Moscow, Idaho (in press).

, 1994. Conservation and management of neotropical migrant landbirds in the northern Rockies and Great Plains. p. 220. University of Idaho Press, Moscow, Idaho.

Drouet, F., 1960. Algal flora of the Nevada Test Site. The Colorado Wyoming Academy of Science. 4:3.

Environmental Laboratory, 1987. U.S: Army Corps of Engineers wetlands delineation manual. U.S. Army Eng. Waterway Exp. Sta. Tech. Rep. Y-87-1, p. 100.

Federal Register, 1996. Record of Decision: Environmental Impact Statement for the Nevada Test Site and Off-Site Locations in the State of Nevada. Vol 61, No. 241, p. 65551. U.S. Government Printing Office, Washington, DC.

- 1982. Title 33: Navigation and Navigable Waters; Chapter II, Regulatory Programs of the Corps of Engineers. Vol 47, No. 138, p. 31810. U.S. Government Printing Office, Washington, DC.

- 1980. 40CFR Part 230: Section 404(b)(1), Guidelines for Specification of Disposal Sites for Dredged or Fill Material. Vol 45, No. 249, p. 85352-85353. U.S. Government Printing Office, Washington, DC.

Fernald, A. T., G. S. Corchary, and W. P. Williams, 1968. Surficial Geologic Map of Yucca Flat, Nye and Lincoln Counties, Nevada. U.S. Department of the Interior, U.S. Geological Survey. Miscellaneous Geologic Investigations Map 1-550.

Frizzell, V. A. Jr., and J. Shulters, 1990. A geologic map of the Nevada Test Site, Southern Nevada. U.S. Geological Survey, U.S. Department of the Interior.

Giles, K. R., 1976. Springs on the Nevada Test Site and their use by wildlife. NERCLV-539-26, p. 14. U.S. Environmental Protection Agency, Las Vegas, Nevada, April, 1976.

Greger, P. D., 1995. Status of horses, deer, and birds on the Nevada Test Site. In: Status of the flora and fauna of Nevada Test Site 1994. DOE/NV/11432-195. Compiled by R. B. Hunter.

Greger, P. D., 1994. Status of large mammals and birds on the Nevada Test Site in 1993. In: Status of the flora and fauna on the Nevada Test Site, 1993. DOE/NV/11432162, pp. 124-149. Compiled by R. B. Hunter.

Greger, P. D., and E. M. Romney, 1994a. Trends in wildlife utilization of water sources and adjacent habitats at the Nevada Test Site from 1989-1991. In: Status of the flora and fauna on the Nevada Test Site, 1989- 1991. DOE/NV/11432-57, pp. 170-235. Compiled by R. B. Hunter. 
Greger, P. D., and E. M. Romney, 1994b. Status of large mammals and birds on the Nevada Test Site, 1992. In: Status of flora and fauna on the Nevada Test Site, 1992. DOE/NV/11432-58, pp. 144-175. Compiled by R. B. Hunter.

Hayward, C. L., M. L. Killpack, and G. L. Richards, 1963. Birds of the Nevada Test Site. Brigham Young University Science Bulletin, Biological Series, Vol 3. No.1, p. 27.

Henton G. H., and L. C. Pippin, 1988. Prehistoric and historic archaeology of Fortymile Canyon, Yucca Wash, and Midway Valley, near Yucca Mountain, Nye County, Southern Nevada. Technical Report 60, p. 163. Desert Research Institute, University of Nevada System.

Hersher, R., and W. L. Pratt, 1990. A new Pyrgulopsis (Gastropoda: Hydrobiidae) from southwestern California, with a model for historical development of the Death Valley hydrographic system. Proceedings of the Biological Society of Washington. 103(2):279-299.

Ingraham, N. L., B. F. Lyes, R. L. Jacobson, and J. W. Hess, 1991. Stable Isotopic Study of Precipitation and Spring Discharge in Southern Nevada. Journal of Hydrology 125: $243-258$.

Jorgensen, C. D., and C. L. Hayward, 1965. Mammals of the Nevada Test Site. Brigham Young University Science.Bulletin, Biological Series 6(3):1-81.

Knopf, F. L., R. R. Johnson, T. Rich, F. B. Samson, and R. C. Szaro, 1988a. Conservation of riparian ecosystems in the United States. Wilson Bulletin 100:272-284.

Knopf, F. L., J. A. Sedgewick, and R. W. Cannon, 1988b. Guild Structure of a riparian avifauna relative to seasonal cattle grazing. Journal of Wildlife Management $52: 280-290$.

Lewis G. B., M. A. Glora, and I. Aoki, 1965. Environmental Radioactivity at the Nevada Test Site. NVO-162-18. Radiological Services Department, U.S. Department of Energy/Nevada Operations Office, Las Vegas, Nevada.

Lyles, B. F., J. Edkins, R. L. Jacobson, and J. W. Hess, 1990. Time-series analysis of ion and isotope geochemistry of selected springs of the Nevada Test Site, Nye County, Nevada. DOE/NV/10384-27, p. 121. Water Resources Institute, Desert Research Institute, University of Nevada System.

McKeown, F. A., D. L. Healey, and C. H. Miller, 1976. Geologic Map of the Yucca Lake Quadrangle, Nye County, Nevada. Map GQ-1327, 1:24,000. U.S. Geological Survey, U.S. Department of the Interior.

Moore, J. E., 1961. Records of wells, test holes, and springs in the Nevada Test Site and surrounding area. U.S. Geological Survey open-file report TEI-781, p. 22. 
Munsell, 1992. Munsell soil color charts. Macbeth Division of Kollmorgen Instruments Corp., Newburgh, New York.

Murie, O. J., 1974. A field guide to animal tracks. p. 375. Second Edition. Houghton Mifflin Company, Boston, Massachusetts.

Nature Conservancy and U.S. Fish \& Wildlife Service, 1996. A checklist of the vascular plants of Ash Meadows National Wildlife Refuge, Nye county, Nevada. The Nature Conservancy, Nevada Field Office, Las Vegas, Nevada; and U.S. Fish and Wildlife Service, Ash Meadows National Refuge, Pahrump, Nevada.

NRCS (Natural Resources Conservation Service), 1996a. Nevada plant species list. USDA National Plant Data Center, Internet (http://trident.ftc.nrcs.usa.gov/pdc/31wht-nw.html), downloaded on September 10, 1996.

- 1996b. Field indicators of hydric soils in the United States. Version 3.0, May 1996. U.S. Department of Agriculture, Natural Resources Conservation Service in cooperation with National Technical Committee for Hydric Soils, Washington, DC.

NRC (National Research Council), 1995. Wetlands: Characteristics and Boundaries, Committee on Characterization of Wetlands. National Academy Press, Washington, DC.

O'Farrell, T. P,. and L. A. Emery, 1976. Ecology of the Nevada Test Site: A Narrative Summary and Annotated Bibliography. Report NVO-167, U.S. Energy Research and Development Administration (ERDA).

Ohmart, R. D., 1994. The effects of human induced changes on the avifauna of western riparian habitats. In: J. R. Jehl Jr., and N. K. Johnson (eds.), A century of avifaunal change in western North America. Studies in Avian Biology. Vol. 15, pp. 273-285.

Raytheon Services Nevada, 1994. Flood Assessment at the Proposed Area 6 Liquid Waste Treatment System. DOE/Nevada Test Site, Nye County, Nevada. Draft, October 1994.

Reed, P. B., Jr., 1996. National list of plant species that occur in wetlands: Intermountain (Region 8) revised draft. National Ecology Research Center, U.S. Fish and Wildlife Service, St. Petersburg, Florida.

Rhoads, W. A., and M. P. Williams, 1977. Status of endangered and threatened plant species on the Nevada Test Site - A survey. EG\&G Report 1183-2356. Santa Barbara, California. 
Romney, E. M., and P. D. Greger, 1992. Wildlife utilization of natural springs and manmade water sources at the Nevada Test Site. In: Status of the flora and fauna on the Nevada Test Site, 1988. DOE/NV/10630-29, pp. 161-181. Compiled by R. B. Hunter.

Saethre, M. B., 1994. Trends in small mammal populations on the Nevada Test Site in 1993. In: Status of the flora and fauna on the Nevada Test Site, 1993. DOE/NV/11432-162, pp. 36-103. Compiled by R. B. Hunter.

Shields, L. M., and F. Drouet, 1962. Distribution of terrestrial algae within the Nevada Test Site. American Journal of Botany 49 (6): 547-554.

Schoff, S. L., and J. E. Moore, 1964. Chemistry and movement of ground water, Nevada Test Site. TEI-838. U.S. Geological Survey.

Smith, D. D., A. B. Crockett, D. E. Bernhardt, K. R. Giles, and R. R. Kinnison, 1979. Animal investigation program 1979 annual report: Nevada Test Site and vicinity. Report No. EMSL-LV-0539-26, p. 90. U.S. Environmental Protection Agency, Las Vegas, Nevada.

Smith, D. D., K. R. Giles, D. E. Bernhardt, and K. W. Brown, 1978. Animal investigation program 1975 annual report: Nevada Test Site and vicinity. Report No. EMSL-LV-0539-14, p. 45. U.S. Environmental Protection Agency, Las Vegas, Nevada.

Starkweather, P., 1995. Modern and paleolimnology of the endorheic playas of the Nevada Test Site. University of Nevada, Las Vegas. Final report to DOE/NV DE-FC08-93NV11399, p.19 plus figures. Supported under the cooperative agreement with the U.S. Department of Energy.

Stetzenbach, K. J., 1995. Fingerprinting of ground water by ICP-MS. Unpublished progress report DOE/NV/10872-T203. Harry Reid Center for Environmental Studies, University of Nevada, Las Vegas, Nevada.

Stoffle, R.W., J. E. Olmsted, and M. J. Evans, 1990a. Literature review and ethnohistory of Native American occupancy and use of the Yucca Mountain area. DOE/NV10576-21, p. 197. Institute for Social Research, University of Michigan, Ann Arbor, Michigan. Report to Science Applications International Corporation, LasVegas, Nevada.

Stoffle, R.W., D. B. Halmo, J. E. Olmsted, and M. J. Evans, 1990b. Native American cultural resource studies at Yucca Mountain Nevada. p. 232. Institute for Social Research. The University of Michigan, Ann Arbor, Michigan. Report to Science Applications International Corporation, Las Vegas, Nevada. 
Stoffle, R.W., M. J. Evans, D. B. Halmo, W. E. Niles, and J. T. O'Farrell, 1989. Native American plant resources in the Yucca Mountain area, Nevada. DOE/NV-1057619, p. 142. Institute for Social Research, University of Michigan, Ann Arbor, Michigan. Report to Science Applications International Corporation, Las Vegas, Nevada.

Taylor, W. D., and K. R. Giles. 1979. Freshwater algae of the Nevada Test Site. Report EMS6-LV-0539-25, p. 19. U.S. Environmental Protection Agency. Las Vegas, Nevada.

Thordarson, W., and B. P. Robinson, 1971. Wells and springs in California and Nevada within 100 miles of the point $37^{\circ} 15^{\prime}$ N., $116^{\circ} 25^{\prime}$ W., on Nevada Test Site. U.S. Geological Survey Report 474-85, p. 178. Denver, Colorado.

Thordarson, W., 1965. Perched ground water in the zeolitized-bedded tuff, Rainier Mesa and vicinity, Nevada Test Site. U.S. Geological Survey open-file report TEI-862, p. 90.

U.S. Army Corps of Engineers, 1985. Regulatory Program, Applicant Information. United States Army Corps of Engineers, EP 1145-2-1, May 1985.

U.S. Department of Energy, 1996a. Final Environmental Impact Statement for the Nevada Test Site and Off-Site Locations in the State of Nevada. DOE/EIS 0243. Volume 1, Chapters 1-9. August 1996.

— , 1996b. Framework for the Resource Management Plan, Final Environmental Impact Statement for the Nevada Test Site and Off-Site Locations in the State of Nevada. DOE/EIS 0234. Volume 2. U.S. Department of Energy/Nevada Operations Office, Las Vegas, Nevada.

— 1988. Site Characterization Plan, Yucca Mountain Site, Nevada Research and Development Area, Nevada. DOE/R.W.-0199, Volume 11, Part A.

U.S. Department of Interior. 1994. An Ecosystem Approach to Fish and Wildlife Conservation, U.S. Fish and Wildlife Service, Washington, DC.

U.S. Salinity Laboratory, 1954. Diagnosis and improvement of saline and alkali soils. Agriculture Handbook 60, USDA.

Warner, R. E., and K. M. Hendrix, 1984. California riparian systems: ecology, conservation and productive management. p. 1035. University of California Press, Berkeley, California.

Williams, A. E., 1992. Clarification and Interpretation of the 1987 Manual, USACE Memorandum from Arthur E. Williams, Major General, USA, Directorate of Civil Works, Correspondence CECW-OR. 
Winograd, I. J., and W. Thordarson, 1975. Hydrogeologic and Hydrochemical Framework, South-Central Great Basin, Nevada-California, with special reference to the Nevada Test Site. Hydrology of Nuclear test Sites. U.S. Geological Survey Professional Paper 712-C, p. 126. U.S. Department of Interior.

Worman, F. C. V., 1969. Archeological investigations at the U.S. Atomic Energy Commission's Nevada Test Site and Nuclear Rocket Development Station. LA-4125, p. 201. Los Alamos Scientific Laboratory of the University of California, Los Alamos, New Mexico. 
This Page Intentionally Left Blank 
APPENDIX A

LIST OF SCIENTIFIC AND

COMMON PLANT. NAMES 


\begin{tabular}{|c|c|c|c|}
\hline SCIENTIFIC NAME & COMMON NAME & SCIENTIFIC NAME & COMMON NAME \\
\hline Trees/Shrubs & & Grasses/Rushes/Sedges (Cont.) & \\
\hline Ambrosia dumosa & white burrobush & Bromus rubens & foxtail brome \\
\hline Amelanchier utahensis & Utah serviceberry & Bromus tectorum & cheatgrass \\
\hline Artemisia tridentata & big sagebrush & Carex sp. & sedge \\
\hline Atriplex canescens & fourwing saltbush & Carex alma & sturdy sedge \\
\hline Atriplex confertifolia & shadscale saltbush & Carex praegracilis & clustered field sedge \\
\hline Baccharis emoryi & Emory's baccharis & Carex alma & sturdy sedge \\
\hline Cercocarpus intricatus & littleleaf mountain mahogany & Carex praegracilis & clustered field sedge \\
\hline Chrysothamnus sp. & rabbitbrush & Dactylis glomerata & orchardgrass \\
\hline Chrysothamnus viscidiflorus & green rabbitbrush & Deschampsia danthonioides & annual hairgrass \\
\hline Coleogyne ramossisima & blackbrush & Distichlis spicata & inland saltgrass \\
\hline Encelia virginensis & Virgin River brittlebush & Eleocharis palustris & common spikerush \\
\hline Ephedra nevadensis & Nevada jointfir & Eleocharis parishii & Parish's spikerush \\
\hline Ephedra viridis & mormon tea & Elymus elymoides & bottlebrush squirreltail \\
\hline Ericameria cooperi & Cooper's heathgoldenrod & Elymus sp. & wildrye \\
\hline Ericameria nauseosa & rubber rabbitbrush & Hordeum jubatum & foxtail barley \\
\hline Ericameria teretifolia & needle leaf rabbitbrush & Hordeum murinum ssp. glaucum & smooth barley \\
\hline Eriogonum fasciculatum & eastern Mojave buckwheat & Juncus balticus & baltic rush \\
\hline Grayia spinosa & spiny hopsage & Juncus longistylis & longstyle rush \\
\hline Juniperus osteosperma & Utah juniper & Juncus saximontanus & Rocky Mountain rush \\
\hline Larrea tridentata & creosote $+\mathrm{B} 3$ bush & Leymus cinereus & basin wildrye \\
\hline Pinus monophyla & singleleaf pinyon & Leymus triticoides & beardless wildrye \\
\hline Populus fremontii & Fremont's cottonwood & Phragmites australis & common reed \\
\hline Prosopis glandulosa var. torreyana & western honey mesquite & Poa secunda & Sandberg bluegrass \\
\hline Prunus fasciculata & desert almond & Poa sp. & bluegrass \\
\hline Purshia glandulosa & desert bitterbrush & Polypogon interruptus & ditch polypogon \\
\hline Purshia stansburiana & Stansbury cliffrose & Polypogon monspeliensis & annual rabbitsfoot grass \\
\hline Purshia tridentata & antelope bitterbrush & Polypogon viridis & beardless rabbitsfoot grass \\
\hline Quercus gambelii & Gambel's oak & Potamogeton pectinatus & sago pondweed \\
\hline Rhus trilobata & skunkbush sumac & Sporobolus airoides & alkali sacaton \\
\hline Salazaria mexicana & Mexican bladdersage & Typha domingensis & southern cattail \\
\hline Salix exigua & sandbar willow & Typha latifolia & broadleaf cattail \\
\hline Salix gooddingii & Goodding's willow & & \\
\hline Symphoricarpos longiflorus & desert snowberry & Forbs & \\
\hline Tamarix chinensis & fivestamen tamarisk & & \\
\hline Tamarix ramosissima & saltcedar & Amaranthus albus & prostrate pigweed \\
\hline Yucca brevifolia & Joshua tree & Artemisia dracunculus & wormwood \\
\hline Yucca schidigera & Mojave yucca & $\begin{array}{l}\text { Artemisia ludoviciana } \\
\text { Berula erecta }\end{array}$ & $\begin{array}{l}\text { Louisiana sagewort } \\
\text { cutleaf waterparsnip }\end{array}$ \\
\hline Grasses/Rushes/Sedges & & $\begin{array}{l}\text { Camissonia megalantha } \\
\text { Camissonia sp. }\end{array}$ & $\begin{array}{l}\text { largeflower suncup } \\
\text { suncup }\end{array}$ \\
\hline $\begin{array}{l}\text { Agrostis exarata var. monolepis } \\
\text { Bromus diandrus }\end{array}$ & $\begin{array}{l}\text { monolepis bentgrass } \\
\text { ripgut brome }\end{array}$ & Castilleja applegatei ssp. martinii & $\begin{array}{l}\text { Martin's wavyleaf Indian } \\
\text { paintbrush }\end{array}$ \\
\hline
\end{tabular}

* Species nomenclature is according to NRCS, 1996a 
Appendix A. List of scientific and common plant names*

\begin{tabular}{|c|c|}
\hline SCIENTIFIC NAME & COMMON NAME \\
\hline Forbs (Cont.) & \\
\hline Cirsium neomexicanum & New Mexico thistle \\
\hline Cleome lutea & yellow spiderflower \\
\hline Conyza canadensis & Canadian horseweed \\
\hline Encelia sp. & brittlebush \\
\hline Epilobium ciliatum & hairy willowherb \\
\hline Epilobium glaberrimum & smooth willowweed \\
\hline Erigeron divergens & spreading fleabane \\
\hline Erodium cicutarium & redstem stork's bill \\
\hline Galium aparine & stickywilly \\
\hline Halogeton glomerata & halogeton \\
\hline Heliomeris multiflora var. nevadensis & Nevada goldeneye \\
\hline Kochia scoparia & common kochia \\
\hline Lactuca serriola & prickly lettuce \\
\hline Linum lewisiï & prairie flax \\
\hline Linum sp. & flax \\
\hline Lotus sp. & trefoil \\
\hline Melilotus indicus & annual yellow sweetclover \\
\hline Mimulus guttatus & seep monkeyflower \\
\hline Oenothera cespitosa ssp. marginata & tufted eveningprimrose \\
\hline Penstemon rostriflorus & Bridge penstemon \\
\hline Penstemon sp. & penstemon \\
\hline Pentagrama triangularis & western goldfern \\
\hline Potentilla biennis & biennial cinquefoil \\
\hline Pseudognaphalium stramineum & straw falsecudweed \\
\hline Rumex crispus & curly dock \\
\hline Rumex salicifolius & willow dock \\
\hline Salsola paulsensii & prickly Russian thistle \\
\hline Sisymbrium altissimum & tall tumblemustard \\
\hline Suaeda moquinii & Mojave seablite \\
\hline Verbena bracteata & bigbract verbena \\
\hline Veronica anagallis-aquatica & water speedwell \\
\hline
\end{tabular}

*Species nomenclature is according to NRCS, 1996a 


\section{APPENDIX B \\ DATA SHEETS FOR ROUTINE \\ JURISDICTIONAL WETLAND DETERMINATION}




\section{Routine Jurisdictional Wetland Determination}

Name: PDG. DJH

Location: Ammonia Tanks

Date: $1-7-97$

\section{Hydrology}

Type: Seep Spring ___ Pond Detention basin Wetland Unit: Wash pool UTM Coordinates Easting: 5-62-850 Northing: 41-10-240 Natural Tanks $\mathrm{X}$

Source: Natural $\mathrm{X}$ Man-enhanced Man-made Ephemeral $\mathrm{X}$ Permanent

Date of construction/Period of flow: On 1-7-97 there was no water flow out of the tanks.

Disturbance type (if any) and date: None: A nearby rock shelter indicates human historical use

Inundated:Yes $X$ No _ Depth of standing water $>50 \mathrm{~cm}$; Saturated: Yes_ $X$ Other field indicators:

Atypical situation: Yes_ No $\mathrm{X}$;

Basis: Surface water exists at the observation point.

\section{Wetland hydrology: Yes $\mathrm{X}$ No}

Vegetation List 3 dominant species, percent cover in bold, in each vegetation layer ( 5 if only 1 or 2 layers are present)

Trees Species Indicator Status ${ }^{a}$

$\%$ Cover

1. none

2.

3.

4.

5.

\section{Shrubs}

1. none

2.

3.

4.

5.

\section{Herbs}

1. Artemisia ludoviciana

2. Encelia sp.

3. Juncus balticus

4. Leymus cinereus

5.

6.

7.

8.

9.

10.
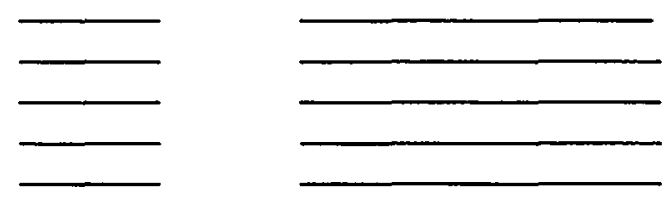

Other field indicators:

Percentage of species that are OBL, FACW, and/or FAC: $\quad 0 \quad \%$; Hydrophytic vegetation: Yes
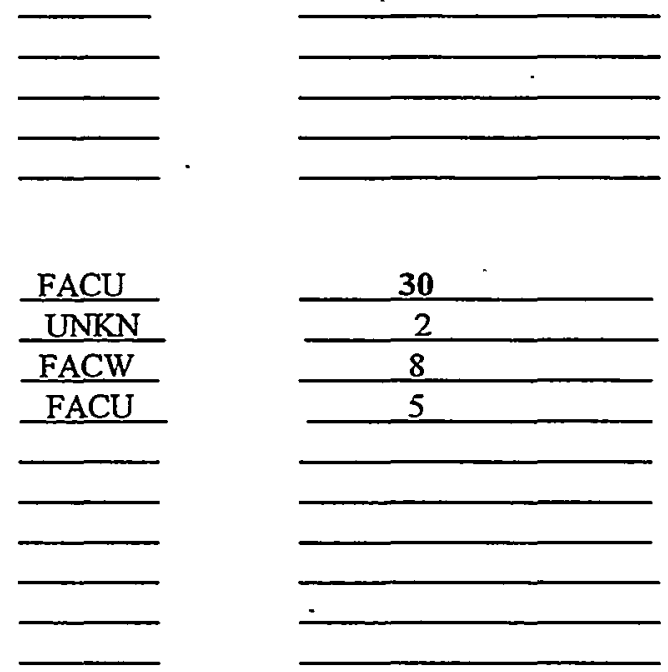

Basis: Lack of dominance of hydrophytic species at the observation point.

\section{Hydric Soils}

Field indicators: Hydric soils exist at the observation point due to presence of saturated soils for longer than 7 days duration.

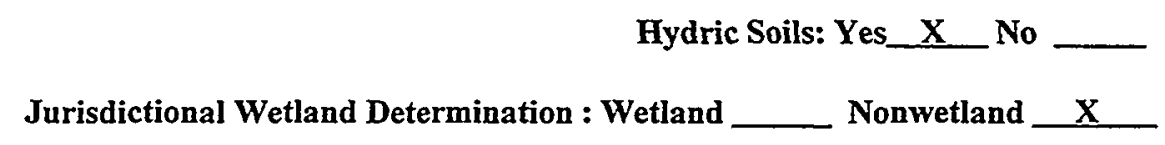

Notes:

${ }^{2}$ Wetland indicator status for plants in region $8 . \mathrm{FACW}=$ facultative wetland species. FACU $=$ Facultative upland species. UNKN $=$ Unknown wetland status of this species. 


\section{Routine Jurisdictional Wetland Determination}

Name: PDG, DJH, JAA

Wetland Unit:Drainage channel below cave pool

Location: Cane Spring

Date: 6-19-96

UTM Coordinates Easting: 5-80-775 Northing: 40-72-730

\section{Hydrology}

Type: Seep __ Spring $\mathrm{X}$ Pond

Detention basin

Stream Mechanically contained

Source: Natural $X$ Man-enhanced $X$ Man-made __ Ephemeral __ Permanent $X$ Temporary Date of construction/Period of flow:Unknown date of construction. PVC pipe directs water from cave to a flow guage box. Disturbance type (if any) and date:Channels dug out leading to a dry pond. An old road forms a berm-Cave adit pool dug out. Inundated:Yes _ No X Depth of standing water 0 ; Saturated: Yes $\mathrm{X}$ No _ Depth to saturation 12"-18" Other field indicators: Hydrobiid snails, Pyrgulopsis sp restricted to cave pool living on filamentous algae present near opening of the cave pool

Atypical situation: Yes _ No $\mathrm{X}$ _ Wetland hydrology: Yes _ No_ X Basis: At the observation point, the outflow channel is dry at the surface, but is saturated at $1 \mathrm{ft}$ depth. No surface outflow from the cave pool occurs on this date. Flow rate measured at the cave pool in November 22,1996 was about 3 liters $/ \mathrm{min}$.

Vegetation List 3 dominant species,\% cover in bold, in each vegetation layer (5 if only 1 or 2 layers are present)

Trees nocies
1. none
2.
3.
4.

Indicator Status ${ }^{a}$

\% Cover

\section{Shrubs}

1. Atriplex canescens

2.

3.

4.

5.
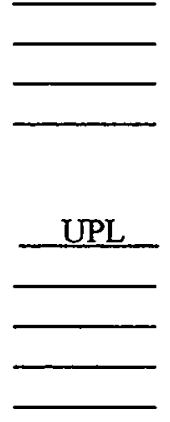

15

Herbs

1. Levmus cinereus

2. Rumex salicifolius
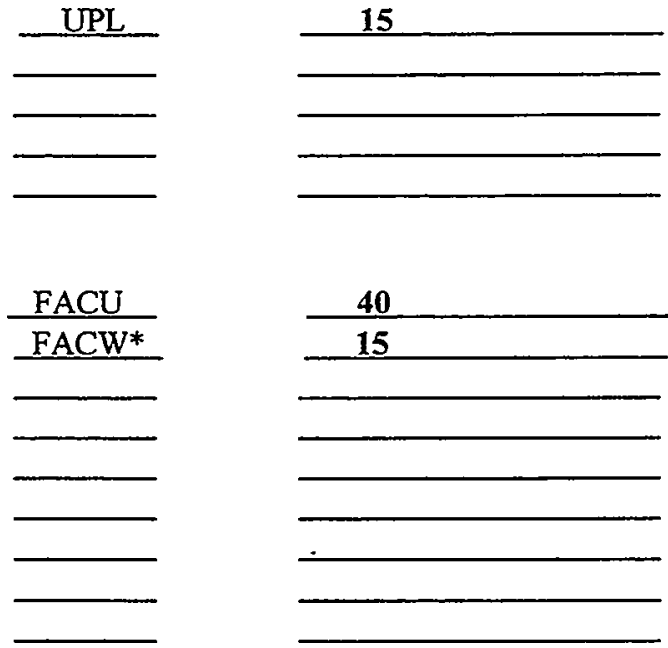

3.

4.

5.

6.

7.

8.

9.

Percentage of species that are OBL, FACW, and/or FAC: $33 \%$; Hydrophytic vegetation: Yes

Basis: Observation point was dry during the survey - other areas nearby have hydrophytic vegetation

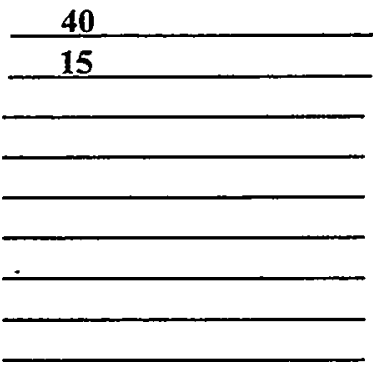

Hydric Soils

Field indicators: Hydric soils-undisturbed: Soils have mottling at depths of about 5-6ft. under the surface, shown on a cut away bank. Overall depths of soils approximately $6-8 \mathrm{ft}$.

Notes:

Jurisdictional Wetland Determination: Wetland

Hydric Soils: Yes__

Meadow above cave pool has Juncus balticus and leymus cinereus $\left(7 \mathrm{~m} \times 10 \mathrm{~m}=70 \mathrm{~m}^{2}\right.$ area); Typha domingensis, Tamarix ramossisima. Salix goodingii. Polvpogon monospeliensis are other species in the area. Cattails occur under large willows. Tamarix $s p$ occurs on the old pond berm (i.e. dirt road). ${ }^{2}$ Wetland indicator status for plants in region 8 . UPL = Upland plant species. $\mathrm{FACW}^{*}=$ tentative assignment as a facultative wetland plant species based on limited information available. FACU $=$ Facultative upland plant species. 


\section{Routine Jurisdictional Wetland Determination}

Name:

PDG

Wetland Unit:Seep under the willow trees

Location: Cane Spring

UTM Coordinates Easting: 5-80-775 Northing: $40-72-730$

Date: 9.9-96

\section{Hydrology}

Type: Seep __ Spring $X$ Pond Detention basin

Source: Natural $X$ Man-enhanced $X$ Man-made

Date of construction/Period of flow:Unknown period of flow

Disturbance type (if any) and date:Channel dug out by man leeds to a dry pond

Inundated:Yes $\mathrm{X}$ No__ Depth of standing water $2-3 \mathrm{~cm}$; Saturated: $Y e s \quad X$ No__ Depth to saturation 0

Other field indicators: Water flow is present under willow $\backslash$ fenced area

Atypical situation: Yes__ No $\mathrm{X}$ _ $\quad$ Wetland hydrology: Yes _ $\mathbf{X}$ No

Basis: Surface water exists at the observation point.

Vegetation List 3 dominant species, $\%$ cover in bold, in each vegetation layer ( 5 if only 1 or 2 layers are present)

\section{Species}

Trees

1. Salix goodingii

2.

3.

4.

5.

\section{Shrubs}

1.

2.

3.

4.

5.

\section{Herbs}

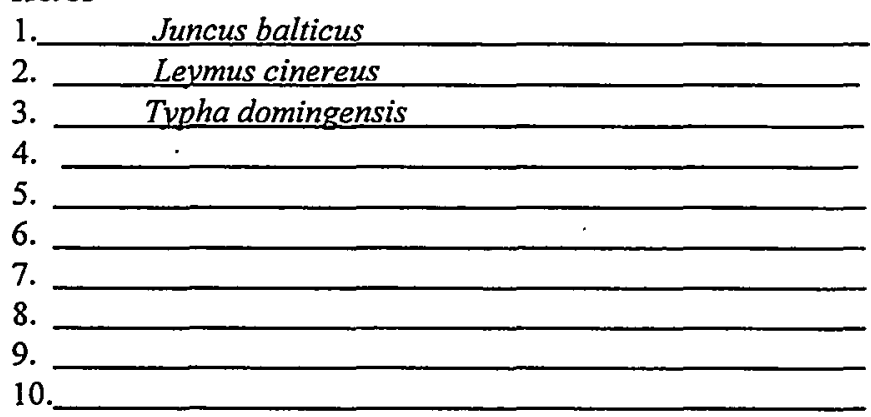

Indicator Status ${ }^{\alpha}$

$\%$ Cover
Mechanically contained Permanent $\underline{X}$ Temporary

Percentage of species that are OBL, FACW, and/or FAC: $75 \%$; Hydrophytic vegetation: Yes $\quad \mathbf{X}$ No Basis: The observation point has a dominance of hydrophytic vegetation. Total wetland area estimated to be about $230 \mathrm{~m}^{2}$.

\section{Hydric Soils}

Field indicators Soil mottling, dark organic soils (low chroma), and soil saturation for greater than 7 days duration are present indicating hydric soils exist at the observation points.

$$
\text { Hydric Soils: Yes } \mathrm{X} \text { No }
$$

\section{Notes :}

Jurisdictional Wetland Determination : Wetland $\mathbf{X}$ Nonwetland

Drainage area appears excavated by man. i.e. man made channel. Polvpogon monospeliensis occurs in the spring area. Hydrobid snails are absent from east channnel (where they occurred in 1988) but are now present only in the cave pool. Wetland indicator status for plants in region 8 . FACU $=$ Facultative upland species. FACW $=$ Facultative wetland species $\underline{\mathrm{OBL}}=$ Obligate wetland species. 


\section{Routine Jurisdictional Wetland Determination}

Name: PDG, DJH, JAA

Location: Captain Jack Spring

Wetland Unit:Drainage channel below pool

Date: 6-19-96

\section{Hydrology}

Type: Seep Spring $\mathrm{X}$ Pond

Detention basin

Stream Mechanically contained

Source: Natural $X$ Man-enhanced

Man-made

Ephemeral Permanent $\mathrm{X}$ Temporary

Date of construction/Period of flow: In 1977 , pipes were installed which lead to watering tanks. Pipes no longer exist. A metal tank (now dry) was bolted to rocks adjacent to the wash channel. A flood damaged tank exists in the wash. Disturbance type and date: Heavy feral horse use has apparently impacted upland vegetation near the spring entrance. Inundated:Yes $\mathrm{X}$ No__ Depth of standing water $20 \mathrm{~cm}$; Saturated: Yes $\underline{X}$ No__ Depth to saturation 0 Other field indicators: The spring consists of a small pool ( $24^{\prime \prime} \times 30^{\prime \prime}$ ) and about 8 " deep below some rock ledges with a surface ouflow varies from $20-50 \mathrm{~cm}$ wide by $2 \mathrm{~cm}$ deep. Surface flow out of the pool is $<1 \mathrm{~L} / \mathrm{min}$ on $6-19-96$.

Atypical situation: Yes $\frac{\mathrm{X}}{\text {; }}$;

Wetland hydrology: Yes $\underline{X}$ No

Vegetation List 3 dominant species, \% Cover in bold, in each vegetation layer (5 if only 1 or 2 layers are present) Species

Indicator Status

$\%$ Cover

Trees

1. none

2.

3.

4.

5.

\section{Shrubs}

1. none

2.

3.

4.

5.

\section{Herbs}

1. Mimulus guttatus

2. Potentilla biennis

3. Rumex salicifolius

4. Veronica anagallis-aquatica

5.

6.

7.

8.

9.

Other field indicators:

Percentage of species that are OBL, FACW, and/or FAC: $100 \quad \%$; Hydrophytic vegetation: Yes $\mathrm{X}$ No Basis: The observation point has a dominance of hydrophytic vegetation. Total wetland area is about $30 \mathrm{~m}^{2}$.

\begin{tabular}{ll}
$\frac{\mathrm{OBL}}{\mathrm{FAC}}$ & $\frac{10}{5}$ \\
\hline $\mathrm{FACW}$ & $\mathbf{5 0}$ \\
\hline $\mathrm{OBL}$ & \\
\hline & \\
\hline & \\
\hline
\end{tabular}

Hydric Soils

Field indicators: Hydric soils exist based on the presence of saturated soils for 7 or more days duration.

Hydric Soils: Yes $\mathrm{X}$ No

Notes:

Jurisdictional Wetland Determination : Wetland $\mathrm{X}$ Nonwetland

Drainage from the spring pool continues for $\approx(30 \mathrm{~m}$ length by $1 \mathrm{~m}$ width $)=30 \mathrm{~m}^{2}$ surface area of saturated soils. Soils are very rocky, but with moderate accumulation of fines in the lower end of drainage. ${ }^{2}$ Wetland indicator status for plants in region 8. * Indicates a tentative assignment to the facultative wetland category based on limited information for this species in region 8. FACW $=$ Facultative wetland species. $F A C=$ Facultative wetland species. $\mathrm{OBL}=$ Obligate wetland species . 


\section{Routine Jurisdictional Wetland Determination}

Name: PDG, WKO

Wetland Unit:Drainage channel

Location: Cottonwood Spring (west of Fortymile Canyon) UTM Coordinates Easting 5-54-045 Northing: 40-83-726

Date: $\quad 12-19-96$

\section{Hydrology}

Type: Seep Spring $\mathrm{X}$ Pond

Detention basin Stream Mechanically contained

Source: Natural $X$ Man-enhanced Man-made Ephemeral Permanent $\mathrm{X}$ Temporary

Date of construction/Period of flow: Period of flow unknown

Disturbance type (if any) and date: Old metal pipes exist in wash about $200 \mathrm{~m}$ from the spring site.

Inundated:Yes $\mathrm{X}$ No__ Depth of standing water $1-25 \mathrm{~cm}$; Saturated: Yes $\mathrm{X}$ No__ Depth to saturation 0 Other field indicators: Driftwood occurs in wash adjacent to Cottonwood trees. Water occurs in three areas: the spring pool and seep area below it and two surface channels in a rocky wash. Flow rate of $1 / \mathrm{Lpm}$ was measured in the stream channel 70m below the spring pool on December 19,1996.
Atypical situation:
Yes
No $\mathrm{X}$;
Wetland hydrology: Yes $\mathrm{X}$ No

Basis: Surface water exists at the observation point. Water flows for about $200 \mathrm{~m}$ down the wash

Vegetation List 3 dominant species,\% cover in bold, in each vegetation layer (5 if only 1 or 2 layers are present)

Species

Trees

1.

2.

3.

4.

5.

\section{Shrubs}

1. Rhus trilobata

2.

3.

4.

5.

\section{Herbs}

1. Bromus rubens

2. Mimulus guttatus

3. Pentagramma triangularis (fern)

4.

5.

6.

7.

8.

9.

Percentage of species that are OBL, FACW, and/or FAC: $66 \%$; Hydrophytic vegetation: Yes $\mathbf{X}$ No Basis: Observation point has a dominance of hydrophytic vegetation. Wetland area was estimated at about $130 \mathrm{~m}^{2}$.

\section{Hydric Soils}

Field indicators: Hydric soils exist based on the presence of hydrophytic plants and saturated soils for greater than 7 davs duration. No soil pits were dug at this site.

\section{Jurisdictional Wetland Determination : Wetland $\underline{\mathrm{X}}$ Nonwetland}

Notes:

a Wetland indicator status for plants in region $8 . \mathrm{OBL}=$ Obligate wetland species. NI = Insufficient information to determine wetland status in region 8 . FACW $*=$ Tentative assignment to the facultative wetland category based on limited information for this species in region 8 . NL $=$ Not listed in the National List of Plants that occur in Wetlands for Region 8. $\underline{\text { UPL }}=$ Upland plant species 


\title{
Routine Jurisdictional Wetland Determination
}

Name: PDG, WKO

Wetland Unit: Wash slope

Location: Coyote Spring

UTM Coordinates Easting: 5-83-561 Northing: 40-66-755

Date: 9-4-96

\section{Hydrology}

Type: Seep $\mathrm{X}$ Spring ___ Pond

Source: Natural $\mathrm{X}$ Man-enhanced

Date of construction/Period of flow:N/A

Detention basin

Stream Mechanically contained

Disturbance type (if any) and date: None

Inundated:Yes $X$ No

Depth of standing Man-made Ephemeral $\mathrm{X}$ Permanent Temporary

Other field indicators: Dark colored, wet surface soil found at two locations in the wash.

Atypical situation: Yes__ No $\mathrm{X}$; Wetland hydrology:

Basis: Surface water occurs at two locations at the spring area.

Vegetation List 3 dominant species, \% cover in bold, in each vegetation layer ( 5 if only 1 or 2 layers are present)

Trees nocies
1. none
2.
3.
4.
5.

Indicator Status ${ }^{a} \quad$ \% Cover

\section{Shrubs}

1. none

2.

3.

4.

5.

\section{Herbs}

1. Distichlis spicata

2.

3.

4.

5.

6.

7.

8.

9.

10.
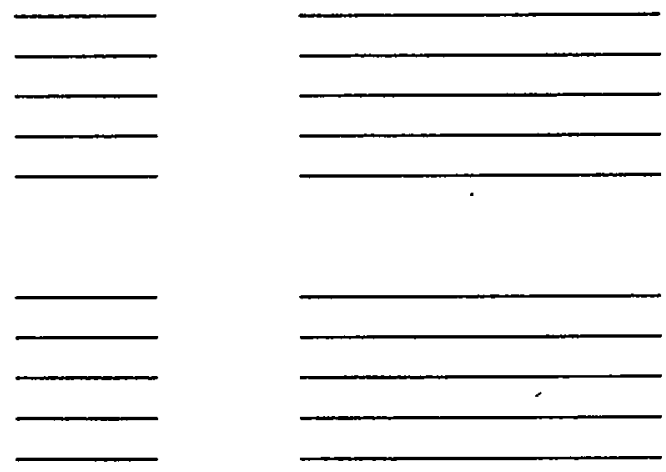

Other field indicators: Dark soil

Percentage of species that are OBL, FACW, and/or FAC: $100 \quad \%$; Hydrophytic vegetation: Yes $\mathbf{X}$ No Basis: The observation point has hydrophytic vegetation. Area of wetland was estimated to be about $200 \mathrm{~m}^{2}$.

Hydric Soils:

Field indicators: Hydric soils exist based on the presence of saturated soils for a period of 7 days or greater duration.

\author{
Hydric Soils: Yes \\ Jurisdictional Wetland Determination : Wetland $\quad \mathrm{X}$ Nonwetland
}

\section{Notes:}

Kochia scoparius (FACU), a facultative upland species occurs nearby. Leymus cinereus (FACU) occurs in a rocky wash $100 \mathrm{~m}$ upstream from the observation point. ${ }^{2}$ Wetland indicator status for plants in region 8 . OBL $=$ Obligate wetland species. FAC+* $=$ Tentative assignment to the facultative wetland category based on limited information available for this species in region 8. 


\section{Routine Jurisdictional Wetland Determination}

Name: PDG

Location: Gold Meadows Spring

Date: $\quad 7-22-96$

\section{Hydrology}

Type: Seep $\mathrm{X}$ Spring _ Pond Detention basin Source: Natural $X$ Man-enhanced $X$ Man-made __ Ephemeral $X$ Permanent _ Temporary Date of construction/Period of flow: There is no surface outflow from the pond.

Disturbance type (if any) and date: Southwest side of the pond has a man-made berm. This was possibly constructed by man to deepen the pond for livestock use. Date of excavation is unknown.

Inundated:Yes _ No $\mathrm{X}$ Depth of standing water $\quad 0$; Saturated: Yes $\mathrm{X}$ No__ Depth to saturation 0 Other field indicators: Dark organic matter, damp mud present - water mark on rocks

Atypical situation: Yes_ No $\mathrm{X}$; Wetland hydrology: Basis: Water marks exist on large rocks at the observation point. Water was present earlier in the year. Survey was conducted during a very dry year.

Vegetation List 3 dominant species, \% cover in bold, in each vegetation layer (5 if only 1 or 2 layers are present)

\section{Trees}

Species

1. none

2.

3.

4.

5.

\section{Slirubs}

1. none

2.

3.

4.

5.

\section{Herbs}

1. Juncus balticus

2.

3.

4.

5.

6.

7.

8.

9.

Oher field indicators:

Percentage of species that are OBL, FACW, and/or FAC 100

, Hydrophytic vegetation: Yes $\underline{X}$ No

Basis: A dominance of hydrophytic plants occurs at the observation point. Wetland area estimated at about $45 \mathrm{~m}^{2}$.

\section{Hydric Soils:}

Field indicators Hydric soils exist based on presence of saturated soils for a period of 7 or greater davs in duration.

\section{Indicator Status ${ }^{a} \quad$ \% Cover}




\section{Routine Jurisdictional Wetland Determination}

Name: $\quad$ WKO

Location: Fortymile Canyon Tanks

Date: $2-12-97$
Wetland Unit: Third Tank downslope from seep UTM Coordinates Easting: 5-57-500 Northing: $\underline{40-85-000}$

\section{Hydrology}

Type: Seep $\mathrm{X}$ Spring ___ Pond ___ Detention basin Source: Natural $x$ Man-enhanced Man-made

Date of construction/Period of flow: Unknown / Winter

Disturbance type (if any) and date: None Inundated:Yes _ No X Depth of standing water___; Saturated: Yes $\mathrm{X}$ No__ Depth to saturation $5 \mathrm{~cm}$ Other field indicators: Water is confined to bedrock pools. Few soil fines in the area. Atypical situation: Yes__ No $\mathrm{X}$; Wetland hydrology Basis: Saturated soils are present at the observation point. Natural water flow exists.

Stream Natural tanks $\mathrm{X}$ Ephemeral $\mathrm{X}$ Permanent Temporary

Vegetation List 3 dominant
Species

Trees

1. none

2.

3.

4.

5.

\section{Shrubs}

1. none

2.

3.

4.

5.

\section{Herbs}

1. Artemisia ludoviciana

2. Bromus rubens

3. Mimulus guttatus

4.

5.

6.

7.

8.

9.

Other field indicators:

Percentage of species that are OBL, FACW, and/or FAC: $33 \%$; Hydrophytic vegetation: Yes

Basis: Hydrophytic plants are absent from the observation point.

\section{Hydric Soils}

Field indicators: Hydric soils exist at the observation point. Saturated soils exist for over 7 days duration.

$$
\text { Hydric Soils: Yes__ X No }
$$
Nonwetland $\mathrm{X}$

Notes:

Several Tanks at the site: 2 pools $3 \mathrm{~m}$ by $1 \mathrm{~m} \times .25 \mathrm{~m}, 2$ pools $1 \mathrm{~m} \times 1 \mathrm{~m} \times .1 \mathrm{~m}, 3$ others smaller occur in a narrow rocky wash bottom. Flow rate was 6 ounces $/ \mathrm{min}$ or $0.18 \mathrm{l} / \mathrm{min}$. Pools contained good growth of algae. Deer and coyote scat were observed in the surrounding wash. 3 golden eagles were observed overhead in flight. Upland species: PUSA, EPVI, ERTE, RHTR, CHVI. EPNE, ARTR. ${ }^{2}$ Wetland indicator status for plants in region 8 . FACU = Facultative upland species. UPL $=$ Upland species. $\mathrm{OBL}=$ Obligate wetland species. 


\section{Routine Jurisdictional Wetland Determination}

Name: PDG, DJH,

Location: John's Spring

Wetland Unit: Ledge pool

Date: $\quad 12-18-96$

UTM Coordinates Easting: 5-82-100 Northing: 41-22-490

\section{Hydrology}

Type: Seep ___ Spring $\mathrm{X}$ Pond

Source: Natural $X$ Man-enhanced

Detention basin

Stream Mechanically contained

Date of construction/Period of flow: None

Disturbance type (if any) and date: None Man-made __ Ephemeral __ Permanent $\underline{X}$ Temporary

Inundated:Yes $X$ No

Other field indicators:

Atypical situation:

Yes

Depth of standing water $2-5 \mathrm{~cm} ;$ Saturated: Yes $\_$N No

Depth to saturation

Basis: Surface water exists at the observation point.

Vegetation List 3 dominant species,\% cover in bold, in each vegetation layer (5 if only 1 or 2 layers are present)

Species

Trees

1. none

2.

3.

4.

5.

\section{Shrubs}

1. Rhus trilobata

2.

3.

4.

5.

\section{Herbs}

1. Carex praegracilis

2. Gallium aparine

3. _L__Lmus cinereus

4. Mimulus guttatus

5. Penstemon sp.

6. Oenothera cespitosa ssp. marginata

7.

8.

9.

Percentage of species that are OBL, FACW, and/or FAC: $100 \%$; Hydrophytic vegetation: Yes __ $\mathbf{X}$ No

Basis: The observation point has a dominance of hydrophytic vegetation. Size of wetland area estimated at about $50 \mathrm{~m}^{2}$.

\section{Hydric Soils}

Field indicators: Hydric soils exist based on the presence of saturated soils for 7 days or greater duration.

\author{
Hydric Soils: Yes $\mathbf{x}$ No \\ Jurisdictional Wetland Determination : Wetland $\mathrm{x}$ Nonwetland
}

Notes:

${ }^{2}$ Wetland indicator status for region $8 . * R$. trilobata and $L$. cinereus occur in the transition zone between the jurisdictional wetland and the upland habitat. OBL $=$ Obligate wetland species. FACW- $=$ Facultative wetland species. FACU $=$

Facultative upland plant species. $\mathrm{NI}=$ Insufficient information to determine wetland status for this species in region 8 .

$\mathrm{NL}=$ not listed in National List of Plants that occur in Wetlands for Region 8. UNKN = Unknown wetland status. 


\section{Routine Jurisdictional Wetland Determination}

Name: PDG

Location: Oak Spring

Date: $\quad 11-4-96$
Wetland Unit: Spring outflow

UTM Coordinates Easting: 5-82-300 Northing: 41-22-400

\section{Hydrology}

Type: Seep $X$ Spring ___ Pond ___ Detention basin ___ Stream __ Mechanically contained Source: Natural $X$ Man-enhanced $X$ Man-made __ Ephemeral __ Permanent $X$ Temporary Date of construction/Period of flow: Unknown period of flow, however flow was reported at 1500-3000 gallons in 1907 by S.H.Ball during a geological survey of southwestern Nevada. Disturbance type (if any) and date: During 1975, a new galvanized tank was installed with a plastic pipe. This renovation replaced the old pipe and tank. No water was present in the metal tanks on 11-4-96. Flow rate measured on December 18, 1996 was about $0.4 \mathrm{l} / \mathrm{min}$. Inundated:Yes $\mathrm{X}$ No__ Depth of standing water $2-3 \mathrm{~cm}$; Saturated: Yes_X No Depth to saturation 0

Other field indicators: Rocky soil - some local excavation of soil (leveling of an area) by man. Atypical situation: Yes__ No $\mathrm{X}$; Wetland hydrology: Yes $\mathrm{X}$ No Basis: Surface water exists at the observation point. Size of the wetland area was estimated at about $40 \mathrm{~m}^{2}$.

Vegetation List 3 dominant species, percent cover in bold, in each vegetation layer ( 5 if only 1 or 2 layers are present) Trees

1.

2.

3.

4.

5 . Species Indicator Status ${ }^{a}$ $\%$ Cover

\section{Shrubs}

1. Rhus trilobata

2. Salix exigua

3.

4.

5.

\section{Herbs}

1. Leymus cinereus
2.
3.
4.
5.
6.
7.
8.
9.
10.
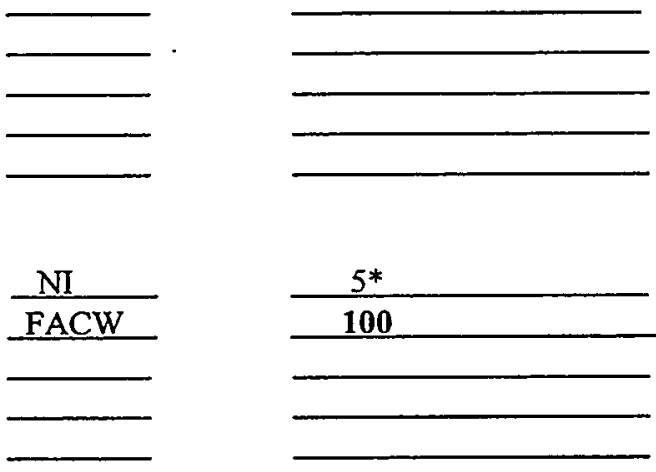

Other field indicators:

Percentage of species that are OBL, FACW, and/or FAC: $100 \%$; Hydrophytic vegetation: Yes $\mathrm{X}$ No Basis: A dominance of hydrophytic vegetation occurs at the observation point.

Hydric Soils

Field indicators: Hydric soils exist based on the presence saturated soils for 7 or greater days duration

Hydric Soils: Yes_ $\mathrm{X}$ No

Notes:

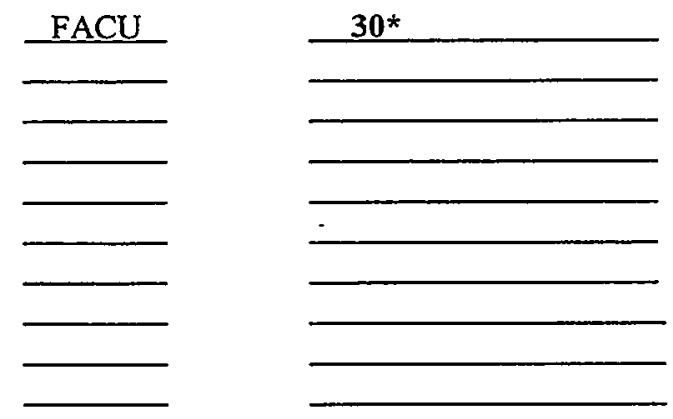

* Leymus cinereus and Rhus trilobata are present on the edge of the delineated wetland and comprised about $30 \%$ cover of this area: ${ }^{2}$ Wetland indicator status for plants in region 8 . FACW $=$ Facultative wetland species. NI = Insufficient information to determine wetlands status of this species in region 8 . FACU $=$ Facultative upland species. 


\section{Routine Jurisdictional Wetland Determination}

Name: $\quad$ PDG,WKO

Location: Pavits Spring

Date: $\quad 9-4-96$

\section{Hydrology}

Type: Seep___ Spring $X$ Source: Natural X Man-enhanced Detention basin Stream Mechanically contained

Date of construction/Period of flow: Winter -spring and fall during wet years

Disturbance type (if any) and date: None

Inundated:Yes _ No $X$ Depth of standing water $\underline{0}$; Saturated: Yes _ No X Depth to saturation not determined Other field indicators: Old water marks and remnants of spring pool with mesic grasses.

Atypical situation: $\quad$ Yes__ No $\mathrm{X}$ _ $;$ Wetland hydrology: Yes X No

Basis: Field indicators (old pool) for hydrology were present at the observation site.

\section{Vegetation List 3 dominant species (\% cover in bold) in each vegetation layer (5 if only 1 or 2 layers are present) Species \\ Indicator Status ${ }^{\circ}$ \\ $\%$ Cover}

Trees

1. none

2.

3.

4.

5.

\section{Shrubs}

1. ___ Ericameria nauseosa

2.

3.

4.

5.

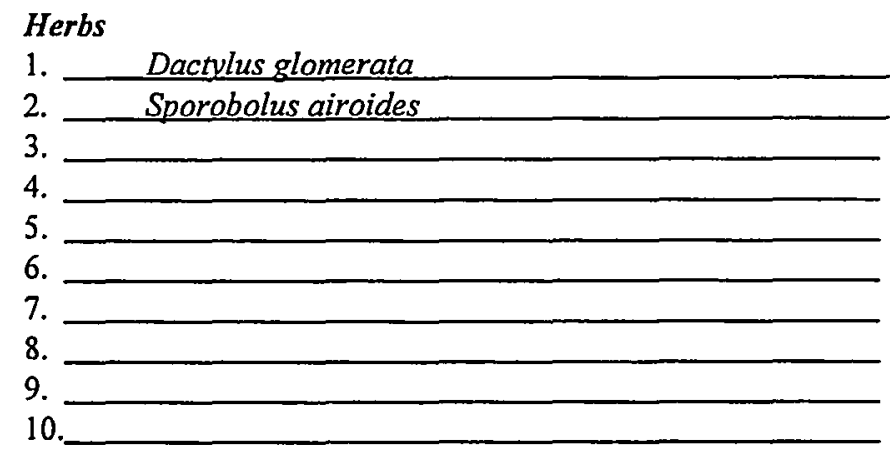

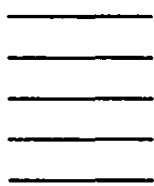
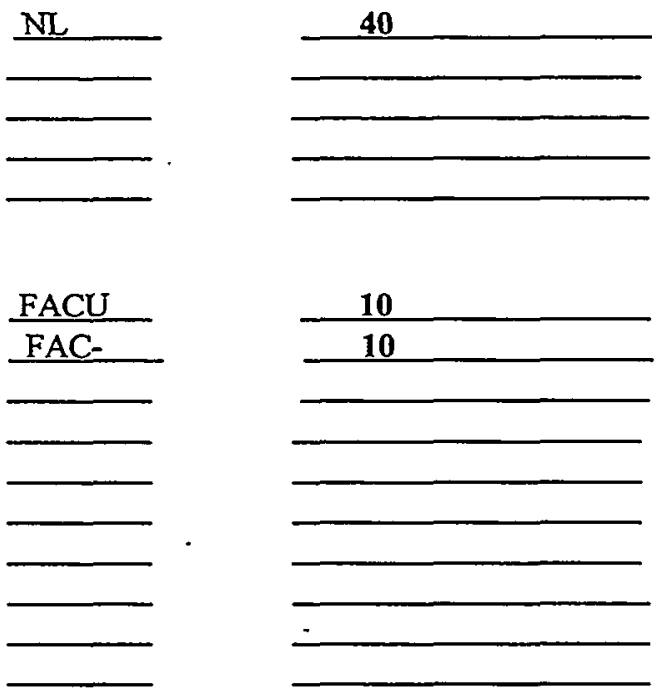

Other field indicators: $\quad$ Mesic grasses including Poa $s p$, and Camissonia sp. Percentage of species that are OBL, FACW, and/or FAC: $33 \%$ _ Hydrophytic vegetation: Yes ___ No_X Basis: A dominance of hydrophytic vegetation is not present at the observation site.

Hydic soils:

Field indicators: None - no inundation (saturated soils) during surveys in September 1996.

Hydric soils: Yes No

Jurisdictional Wetland Determination : Wetland Nonwetland $\mathrm{X}$

Notes:

Wetlands survey was performed during a very dry year. ${ }^{2}$ Wetland indicator status for plants in region 8 . FAC- $=$ Facultative wetland species. FACU = Facultative upland species. NL = Not listed on the National List of Plants that occur in Wetlands for Region 8. 


\section{Routine Jurisdictional Wetland Determination}

Name:

PDG DJH

Location:_Rainier Spring Site

Date: $\quad 12-18-96$
Wetland Unit: Wash bottom

UTM Coordinates Easting: 5-71-463 Northing: $41-16-050$

\section{Hydrology}

Type: Seep _ Spring $\mathrm{X}$ Pond Detention basin

Stream Mechanically contained

Source: Natural $\mathrm{X}$ Man-enhanced $\mathrm{X}$ Man-made__ Ephemeral $\mathrm{X}$ Permanent Temporary

Date of construction/Period of flow: Dry on 12-18-96. Flow was known from records in 1957.

Disturbance type (if any) and date: Some old metal pipes found in wash. A pipe was inserted between some rocks in the wash bottom to diect flow to several water tanks (2-55 gallon drums, formed into guzzlers) and a larger tank ( $8 \mathrm{ft}$ by $2 \mathrm{ft}$ by $2 \mathrm{ft}$ ) was overturned below in the wash.

Inundated:Yes_ No $\mathrm{X}$ Depth of standing water_0; Saturated: Yes_ No_ $\mathrm{X}$ _ Depth to saturation Unknown Other field indicators:

Atypical situation: Yes__ No $\mathrm{X}$; $\quad$ Wetland hydrology: Yes__ No__ Basis: Water is absent from the observation point. A dirt road leading to $B$ Tunnel occurs about 10-20 meters from the spring site and may have been a factor in affecting surface runoff and infiltration of the area before the spring dryed up.

Vegetation List 3 dominant species, percent cover in bold, in each vegetation layer (5 if only 1 or 2 layers are present)

\begin{tabular}{l} 
Species \\
1. none \\
2.. \\
3. \\
5. \\
\hline
\end{tabular}

Indicator Status ${ }^{a}$

$\%$ Cover

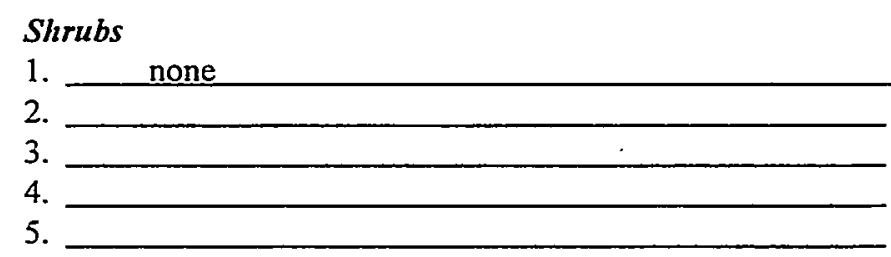

\section{Herbs}

1. Levmus cinereus

2.

3.

4.

5.

6.

7.

8.

9.

Other field indicators:

Percentage of species that are $\mathrm{OBL}, \mathrm{FACW}$, and/or FAC: $\quad 0 \%$; Hydrophytic vegetation: Yes

Basis: Lack of dominance of hydrophvtic vegetation at the observation point.

Hydric Soils

Field indicators: Hydric soils are absent because saturated soils are not present for 7 days or greater duration.

$$
\text { Hydric Soils: Yes }
$$
No

Jurisdictional Wetland Determination : Wetland Nonwetland $\mathrm{X}$

Notes: Records from Moore (1961). (USGS report TEI-781) indicated water (flow) was present on several dates in the fall of 1957 , but the spring was dry in October 1960. ${ }^{\circ}$ Wetland indicator status for plants in region 8 . FACU = Facultative upland species. 


\section{Routine Jurisdictional Wetland Determination}

Name: PDG, JAA, DJH

Wetland Unit: Spring pool

Location: Reitmann Seep

UTM Coordinates Easting: $\underline{5-91-318}$ Northing: $11-05-577$

Date: $\quad 6-19-96$

\section{Hydrology}

Type: Seep $\mathrm{X}$ Spring ___ Pond __ Detention basin Stream Mechanically contained Source: Natural $X$ Man-enhanced $X$ Man-made __ Ephemeral _ Permanent $X$ Temporary Date of construction/Period of flow:Unknown date for water tank emplacement. A 50 gallon drum cut in half was installed in the ground and is normally full of water. Sediment from runoff periodically fills the drum.

Disturbance type (if any) and date: Spring pool often fills with sediment from runoff and was dug out on 6-19-96.

Inundated:Yes $X$ No__Depth of standing water $6-15 \mathrm{~cm}$; Saturated: Yes $X$ No__ Depth to saturation 0 Other field indicators: Water flows into a metal drum from a pipe installed in the ground below the spring pool. Atypical situation: Yes No $\mathrm{X}$; Basis: Surface water is present at the observation point.

Wetland hydrology: Yes $\mathrm{X}$ No

Vegetation List 3 dominant species, percent cover in bold, in each vegetation layer ( 5 if only 1 or 2 layers are present)

\section{Trees} Species Indicator Status ${ }^{a}$

$\%$ Cover

1. none

2.

3.

4.

5.

\section{Shrubs}

1. none

2.

3.

4.

5.

\section{Herbs}

1. Bromus rubens

2. Eleocharis parishii

3. Polypogon monspeliensis

4.

5.

6.

7.

8.

9.

10

Other field indicators:

Percentage of species that are OBL, FACW, and/or FAC: $66 \%$; Hydrophytic vegetation: Yes $\frac{\mathrm{X}}{\text { No }}$

Basis: A dominance of hydrophytic vegetation was present at the observation point. Wetland area $=1 \mathrm{~m}^{2}$.

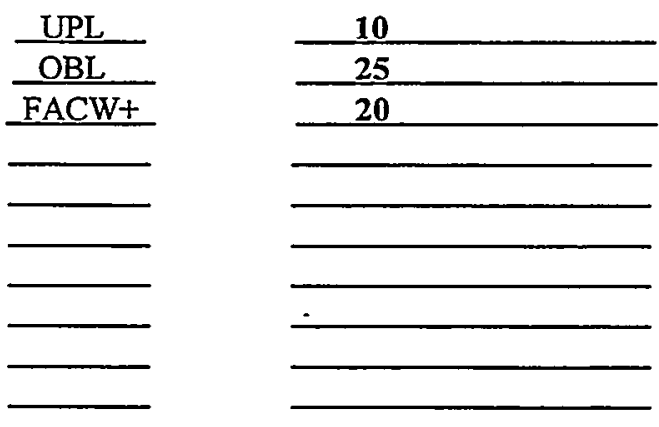

Hydric Soils

Field indicators: Black soils with moderate amounts of organic matter are present: Hydric soils exist based on the presence of saturated soils for greater than 7 days duration. Soil pits were not dug at this site.

$$
\text { Hydric Soils: Yes __ No No }
$$

Jurisdictional Wetland Determination : Wetland $\mathrm{X}$ Nonwetland

\section{Notes:}

Black mucky soil occurs around the spring area. A channel appears dug out for about $10 \mathrm{~m}$ long by $2 \mathrm{~m}$ wide below the spring pool. Berms formed from this apparent disturbance have salt crust and some organic matter. The surface area of spring pool is about $1 \mathrm{~m}^{2}{ }^{2}$ Wetland indicator status for plants in region $8 . \mathrm{OBL}=$ Obligate wetland species. FACW+ is a Facultative wetland species. UPL $=$ Upland plant species. 


\section{Routine Jurisdictional Wetland Determination}

Name: PDG, DJH

Wetland Unit: Solution crevice in limestone outcrop

Location: Rock Valley Tank

UTM Coordinates Easting: 5-68-070 Northing: 40-61-000

Date: 1-7-97

\section{Hydrology}

Type: Seep Spring Pond Detention basin

Source:Natural X Man-enhanced Man-made Ephemeral Stream Natural Tank Permanent $\mathrm{X}$ Temporary Date of construction/Period of flow: Unknown

Disturbance type (if any) and date: None

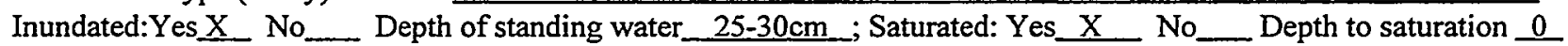
Other field indicators:

Atypical situation: Yes_ No $\mathrm{X}$; $\quad$ Wetland hydrology: Yes $\mathbf{X}$ No Basis: Surface water exists at the observation point but is confined to an opening ( 20 by $40 \mathrm{~cm}$ ) in rock. Water exists in a solution cavern of unknown dimensions.

Vegetation List 3 dominant species, percent cover in bold, in each vegetation layer ( 5 if only 1 or 2 layers are present) Trees Species Indicator Status ${ }^{a} \quad \%$ Cover

1. none

2.

3.

4.

5.

\section{Shrubs}

1. none

2.

3.

4.

5.

\section{Herbs}

1. Bromus rubens
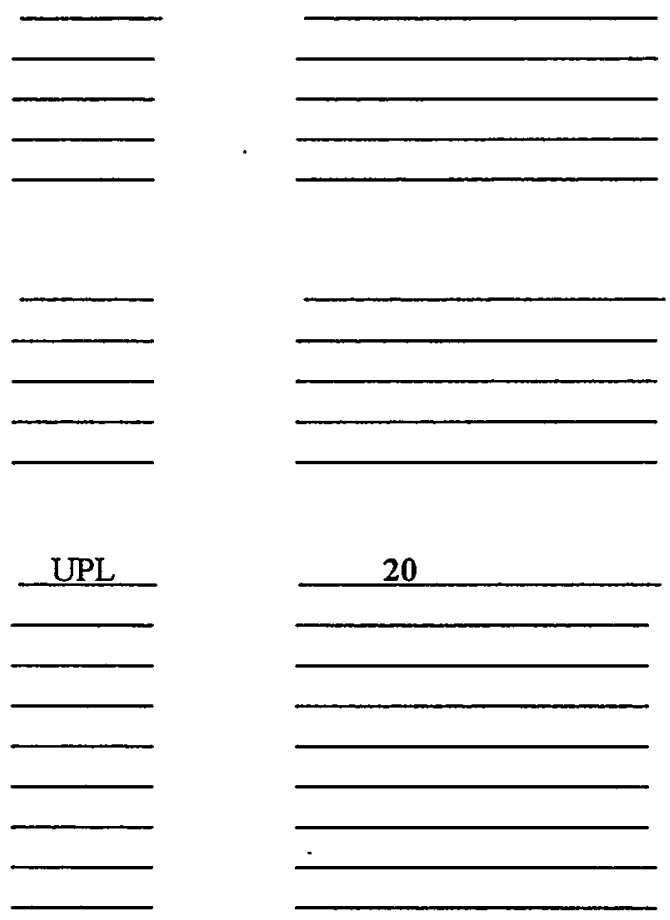

2.

3.

4.

5.

6.

7.

8.

9.
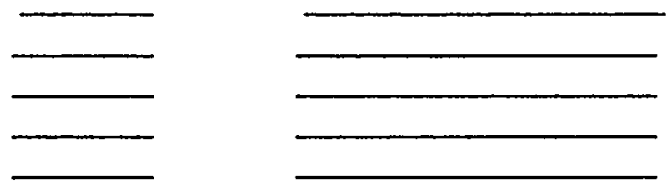

Other field indicators:

Percentage of species that are OBL, FACW, and/or FAC: $\quad 0 \quad \%$; Hydrophytic vegetation: Yes 20

Basis: Hvdrophvtic vegetation is absent from the observation site.

\section{Hydric Soils}

Field indicators: Hydric soils appear to be absent because surface water is confined to a limestone rock opening. An area of dark mesic soil accumulation $(5 \mathrm{~m}$ by $10 \mathrm{~m})$ occurs below the limestone outcrop. Soil depths in this area appear shallow although soil pits were not dug in this area.

\section{Hydric Soils: Yes__ No _ \\ Jurisdictional Wetland Determination : Wetland Nonwetland $\mathrm{X}$}

Notes:

Heavy covote use of the water source is indicated by numerous scats in the area. ${ }^{a}$ Wetland indicator status for plants in region 8. UPL $=$ Upland plant species. 


\title{
Routine Jurisdictional Wetland Determination
}

Name: PDG, JAA

Wetland Unit: Wash channel

Location: Wahmonie Seep 1

UTM Coordinates Easting: $\underline{5-77-631}$ Northing: 40-74-133

Date: 6-20-96

\section{Hydrology}

Type: Seep $X$ Spring ___ Pond Detention basin

Stream Mechanically contained

Source: Natural $X$ Man-enhanced Man-made Ephemeral $\underline{X}$ Permanent Temporary

Date of construction/Period of flow:None/Unknown period of flow

Disturbance type (if any) and date: None

Inundated:Yes $X$ No Depth of standing

Other field indicators:

Surface flow

$X$ wewn the wash but was not measured.

Atypical situation: Yes_ No $\mathrm{X}$;

Basis: Surface water exists at the observation point.

Wetland hydrology: Depth to saturation_ 0

Vegetation List 3 dominant species, percent cover in bold, in each vegetation layer ( 5 if only 1 or 2 layers are present)

\section{Species}

Trees

1. none

2.

3.

4.

5 .

\section{Shrubs}

1. Baccharis emoryi

2. Ericameria nauseosa

3.

4.

5.

\section{Herbs}

1. Artemisia Ludoviciana

2. Juncus balticus

3. Leymus cinereus

4. Mimulus guttatus

5. Polypogon monspeliensis

6. Veronica anagallis-aquatica

7. Moss

8.

9.

10.

Other field indicators:

Percentage of species that are OBL, FACW, and/or FAC: $60 \%$; Hydrophytic vegetation: Yes $\quad \mathbf{X}$ No

Basis: A dominance of hydrophytic vegetation occurs at the observation point. Area of wetland estimated at about $250 \mathrm{~m}^{2}$.

Hydric Soils:

Field indicators: Hydric soils exist at the observation point based on the presence of saturated soils for 7 days or greater duration.

Notes:

\author{
Hydric soils: Yes $\mathbf{X}$ No
}

Jurisdictional Wetland Determination : Wetland _

Tamarix ramosissima exists lower down in the wash from the wetland area. Later in the year Mimulus sp. will be $5 \%$ cover. Veronica sp. and Mimulus sp. are immature at this time (primarily basal leaves are present). Length of wetland area $=15 \mathrm{ft}$ $(5 \mathrm{~m}) \times 120 \mathrm{ft}(40 \mathrm{~m})=200 \mathrm{~m}^{2}$. Surface water occurs in the upper $15 \mathrm{ft}(5 \mathrm{~m})$ of wash. One surface pool was very small $(\approx 1 \mathrm{ft}$. wide $\times 2-3 \mathrm{ft}$. long). ${ }^{2}$ Wetland indicator status for plants in region $8 . \mathrm{NL}=$ not listed in the National List of Plants that occur in Wetlands for Region 8. OBL = Obligate wetland species. FACW, FACW+ are both facultative wetland species. FACU EFacultative upland species. 


\section{Routine Jurisdictional Wetland Determination}

Name: PDG, JAA

Location: Wahmonie Seep 2

Wetland Unit: Wash channel

Date: 6-20-96

\section{Hydrology}

Type: Seep X Spring ___ Pond

Source: Natural $X$ Man-enhanced

Detention basin

Stream

Mechanically contained

Date of construction/Period of flow: None/Unknown availability of water

Disturbance type (if any) and date: None

Inundated:Yes _ No X Depth of standing water 0 ; Saturated: Yes $\_$X No_ Depth to saturation 12 inches

Other field indicators: Surface water was present at this seep on June 6,1996 but not on June 20,1996.

Atypical situation: Yes _ No $\mathrm{X}$; Wetland hydrology: Yes $\mathrm{X}$ No

Basis: Surface water was present at the site during 1996.

Vegetation List 3 dominant species, percent cover in bold, in each vegetation layer (5 if only 1 or 2 layers are present)

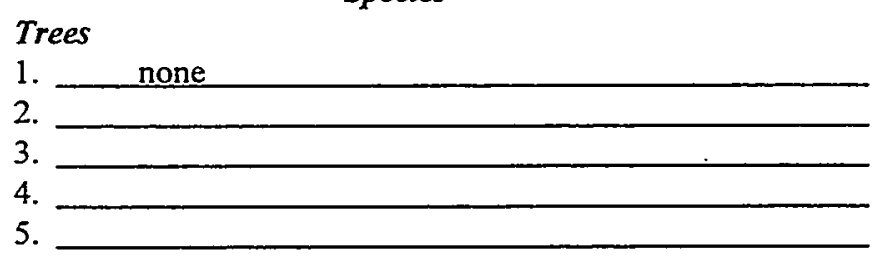

\section{Shrubs}

1. Baccharis emorvi

2.

3.

4.

5 .

\section{Herbs}

1. Artemisia ludoviciana

2. Moss

3.

4.

5.

6.

7.

8.

9.

10.

Other field indicators:

Percentage of species that are OBL, FACW, and/or FAC: $100 \%$;ydrophytic vegetation: Yes $\quad \mathrm{X}$ No Basis: A dominance of hydrophytic plants occurs at the observation point. Wetland area was estimated to be about $150 \mathrm{~m}^{2}$.

Hydric soils

Field indicators: Hydric soils exist based on the presence of saturated soils for a period of 7 days or greater duration.

$$
\begin{aligned}
& \text { Hydric Soils: Yes _ X No } \\
& \text { Jurisdictional Wetland Determination : Wetland } \quad \mathrm{X} \text { Nonwetland }
\end{aligned}
$$

\section{Notes:}

Soils are very rocky. Wetland dimensions are approximately $30 \mathrm{~m} \times 5 \mathrm{~m}$. Damp soil exists under plants in wash. ${ }^{2}$ Wetland indicator status for plants in region $8 . \mathrm{FACW}=$ Facultative wetland species. FACU $=$ Facultative upland species. 


\section{Routine Jurisdictional Wetland Determination}

Name: JAA, PDG

Wetland Unit: Seep channel

Location: Wahmonie Seep 3

UTM Coordinates Easting: 5-77-044 Northing: 40-73-438

Date: 6-20-96

\section{Hydrology}

Type: Seep $\mathrm{X}$ Spring ___ Pond Detention basin

Stream Mechanically contained

Source: Natural $X$ Man-enhanced __ Man-made __ Ephemeral $\bar{X}$ Permanent _ Temporary

Date of construction/Period of flow: None/Unknown seasonal availability of water

Disturbance type (if any) and date: None

Inundated:Yes - No $X$ Depth of standing water 0 ; Saturated: Yes $X$ No _ Depth to saturation undetermined Other field indicators: Water marks on rocks in wash. Surface water was present on June 6, 1996 but not on June 20,1996

Atypical situation: Yes_ No $\mathrm{X}$.

Wetland hydrology: Yes $\mathrm{X}$ No

Basis: Field indicators for surface water were recorded at the observation point.

Vegetation List 3 dominant species, percent cover in bold, in each vegetation layer (5 if only 1 or 2 layers are present)

\section{Trees}

Indicator Status ${ }^{a} \quad \%$ Cover

1. none

2.

3.

4.

5.

\section{Shrubs}

1. Baccharis emorvi

2.

3.

4.

5.

\section{Herbs}

1. Artemisia ludoviciana

2. Bromus rubens

3.

4.

5.

6.

7.

8.

9.

10.

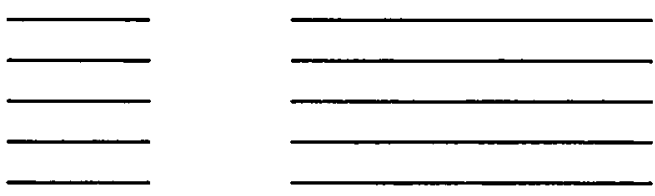

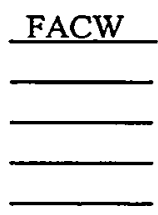

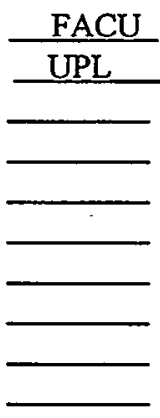

60
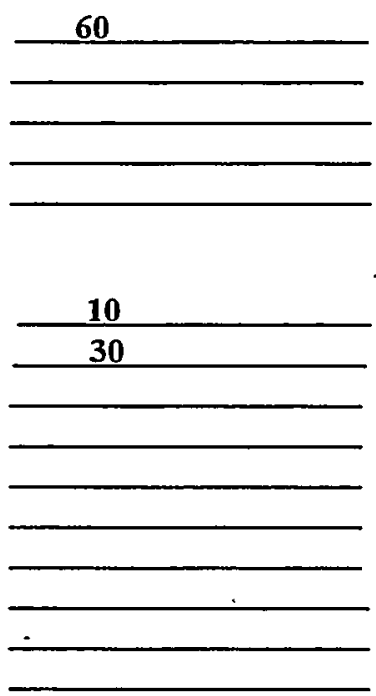

Other field indicators:

Percentage of species that are OBL, FACW, and/or FAC: $33 \% ;$ Hydrophytic vegetation: Yes X No

Basis: A dominance of hydrophytic vegetation occurs at the observation site. Area of wetland estimated to be about $180 \mathrm{~m}^{2}$.

Hydric Soils:

Field indicators: Hydric soils exist based on the presence of saturated soils for 7 days or greater duration during 1996.

$$
\text { Hydric Soils: Yes } \mathrm{X} \text { No }
$$

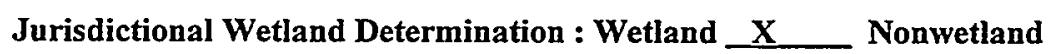

\section{Notes:}

Soils are very thin next to bedrock in the wash bottom. Salt encrusted water marks along the wash occur for 50-60m distance. (Water marks show a 3 meter width). Artemesia ludoviciana $10 \%$ cover, and Bromus rubens $30 \%$ cover, occur on the edges of the wash. ${ }^{a}=$ Wetland indicator status for plants in region 8 . FACW $=$ Facultative wetland species. FACU $=$ Facultative upland species. UPL $=$ Upland plant species. 


\section{Routine Jurisdictional Wetland Determination}

Name: $\quad$ DJH, JAA, PDG

Location: Tippipah Spring

Date:
Wetland Unit: 1 - Upper stretch of the spring channel

UTM Coordinates Easting: $[$ 5-70-810 Northing: 40-99-723

\section{Hydrology}

Type: Seep ___ Spring $\mathrm{X}$ Pond Detention basin

Stream Mechanically contained

Source: Natural $X$ Man-enhanced $X$ Man-made __ Ephemeral _ Permanent $X$ Temporary Date of construction/Period of flow: During wet years, flow extends further down the wash, at least $300-500 \mathrm{~m}$ in length. Disturbance type (if any) and date: Possible man-enhanced deepening of spring channel - Tunnel excavated by man forms an underground pool that collects water before it flows out into a surface channel. The surface channel is narrow and also appears excavated through rocks with side berms of soil placed adjacent to the channel.

Inundated:Yes $\mathrm{X}$ No__ Depth of standing water $15-20 \mathrm{~cm}$; Saturated: Yes $X$ No___ Depth to saturation _ Other field indicators: Spring is associated with old homestead and ranch - old corral - livestock used the area.

Atypical situation: Yes _ No $\mathrm{X} ;$ Wetland hydrology: Yes $\mathbf{X}$ No Basis: Surface water exists at the observation point.

Vegetation List 3 dominant species, percent cover in bold, in each vegetation layer (5 if only 1 or 2 layers are present)

Species

Trees

1. none

2.

3.

4.

5 .

\section{Shrubs}

1. none

2.

3.

4.

5.

\section{Herbs}

1. Carex praegracilis

2. Eleocharis palustrus

3. Heliomeris multiflora var. nevadensis

4. Juncus balticus

5. Polypogon monspeliensis

6. Veronica anagallis-aquatica

7.

8.

Other field indicators:

\section{Indicator Status ${ }^{a}$}
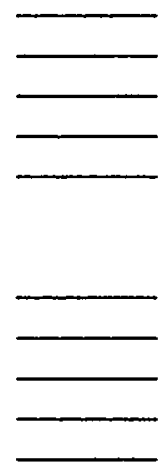

$\%$ Cover

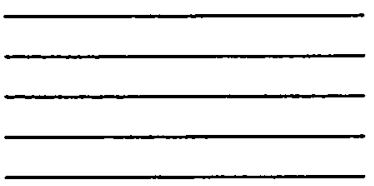

Percentage of species that are OBL, FACW, and/or FAC: $100 \%$; Hydrophytic vegetation: Yes $\mathrm{X}$ No Basis: A dominance of hydrophytic vegetation occurs at the observation point.

\section{Hydric Soils}

Field indicators: Hydric soils are present based on presence of saturated soils for 7 days or greater duration.

$$
\text { Hydric Soils: Yes_ } \mathrm{X} \text { No }
$$

Jurisdictional Wetland Determination : Wetland _

\section{Notes:}

Adjacent to the wetland area is some Ericameria nauseos $a$ and the blackbrush community ${ }_{2}$ Coleogyne ramosissima, with sagebrush Artemisia tridentata further out into the uplands. Typha domingensis also occurs in the area ${ }^{2}=$ Wetland indicator status for plants in region 8. OBL = Obligate wetland species. FACW, FACW + , and FACW-are all facultative wetland species. $N L=$ Not listed on the National List of Plants that occur in Wetlands for Region 8 . Tr. $=$ Trace amounts $(<1 \%$ absolute cover). 


\section{Routine Jurisdictional Wetland Determination}

Name: $\quad$ DJH, PDG, JAA

Wetland Unit:2-Middle stretch of the spring channel

Location: Tippipảh Spring

UTM Coordinates Easting: $\underline{5-70-810}$ Northing: $40-99-723$

Date: 6-18-96

\section{Hydrology}

Type: Seep __ Spring $\mathrm{X}$ Pond Detention basin Stream Mechanically contained Source: Natural $X$ Man-enhanced __ Man-made __ Ephemeral __ Permanent $X$ Temporary Date of construction/Period of flow: None/ unknown

Disturbance type (if any) and date: None

Inundated:Yes $\mathrm{X}$ No Depth of standing water $10-15 \mathrm{~cm}$; Saturated: Yes $\mathrm{X}$ No__ Depth to saturation 0 Other field indicators:

Atypical situation: Yes__ No $\mathrm{X}$ _ Wetland hydrology: Yes $\mathrm{X}$ No Basis: Surface water occurs at the observation point. Flow rate measured about $80 \mathrm{~m}$ downstream from the spring source on November 15,1996 was about $2.7 \mathrm{~L} /$ per min.

Vegetation List 3 dominant species, percent cover in bold, in each vegetation layer (5 if only 1 or 2 layers are present)

Trees necies
1. none
2.
3.
4.
5.
Indicator Status $\%$ Cover

\section{Shrubs}

1. none

2.

3.

4.

\section{Herbs}

1. Bromus rubens

2. Bromus tectorum

3. Castilleja sp.

4. Deschampsia danthonioides

5. Eleocharis parishii

6. Epilobium glaberrimum

7 Heliomeris multiflora var nevadensis

8. Juncus balticus

9. Juncus longistolis

10. Lactuca serriola

11. Polypogon monspeliensis

12. Verbena bracteata

13. Veronica anagallis-aquatica
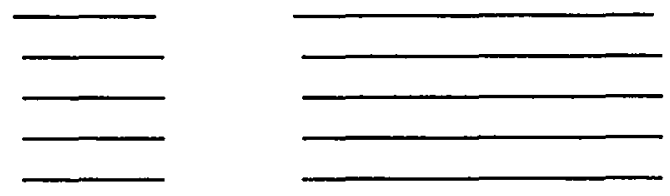

Other field indicators:
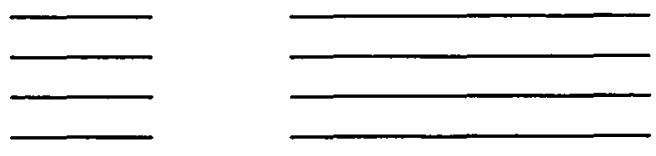

Percentage of species that are OBL, FACW, and/or FAC: $100 \%$; Hydrophytic vegetation: Yes $\mathrm{X}$ No

Basis: A dominance of hydrophytic vegetation exists at the observation point.

Hydric Soils

Field indicators: Hydric soils exist based on the presence of saturated soils for 7 days or greater duration.

Notes:

Hydric Soils: Yes $\mathrm{X}$ No

Jurisdictional Wetland Determination : Wetland $\mathrm{X}$ Nonwetland

Obsidian flakes found at the spring suggest Native American use. $\operatorname{Tr}=\operatorname{Trace}$ amounts $(<1 \%$ cover $) .^{2}=$ Wetland indicator status for plants in region $8 . \mathrm{OBL}=\mathrm{Obligate}$ wetland species. FACW, FACW+ are both facultative wetland species. FACU $=$ Facultative upland species. NL = not listed in National List of Plants that occur in Wetlands for Region 8. UPL = Upland species. UNKN $=$ Unknown status in region 8. 


\title{
Routine Jurisdictional Wetland Determination
}

Name: DJH, PDG JAA

Location: Tippipah Spring

Date: $\quad 6-18-96$
Wetland Unit: 3 - Lower stretch of the spring channel UTM Coordinates Easting: $\underline{5-70-810}$ Northing: $40-99-723$

\section{Hydrology}

Type: Seep __ Spring $X$ Pond

Detention basin

Stream Mechanically contained

Source: Natural X Man-enhanced __ Man-made __ Ephemeral X Permanent __ Temporary

Date of construction/Period of flow: None / Period of flow is dependent on amount of annual rainfall.

Disturbance type (if any) and date: Old livestock corral exits within $100 \mathrm{~m}$ of the sream channel.

Inundated:Yes $\mathrm{X}$ No__ Depth of standing water $5-10 \mathrm{~cm}$; Saturated: Yes $\mathrm{X}$ No__ Depth to saturation_ 0

Other field indicators:

Atypical situation: Yes No N

Wetland hydrology: Yes _ $X$

Basis: Surface water exists at the observation point.

Vegetation List 3 dominant species, percent cover in bold, in each vegetation layer ( 5 if only 1 or 2 layers are present)

Trees Species
1. none
2.
3.
4.
5.

Indicator Statusa

$\%$ Cover

\section{Shrubs}
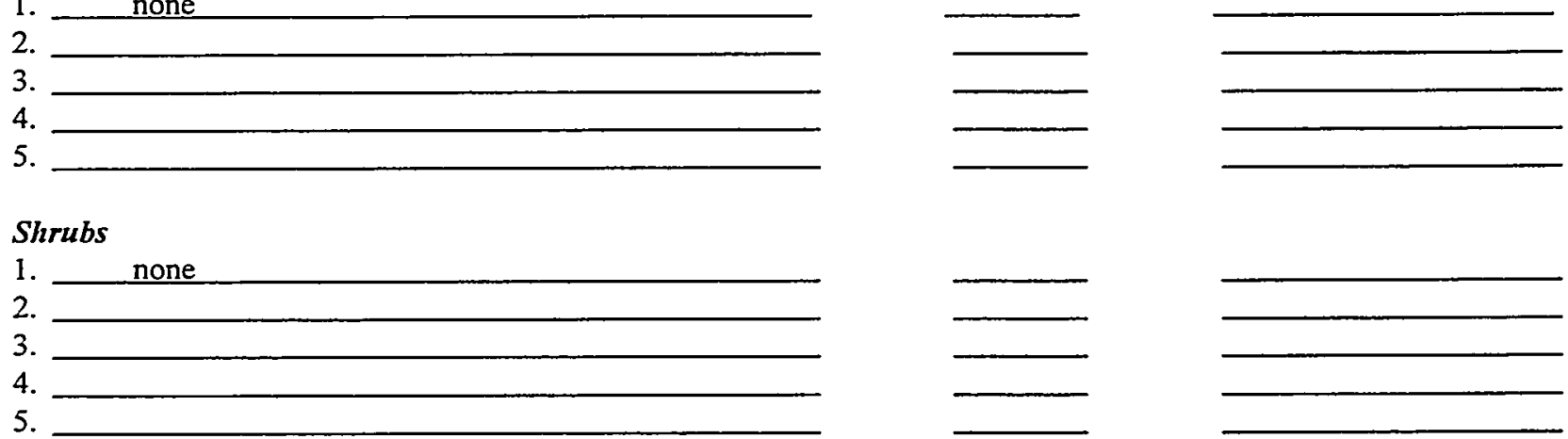

\section{Herbs}

1. Bromus tectorum

2. Erodium cicutarium

3. Heliomeris multiflora var nevadensis

4. Juncus balticus

5. Lactuca serriola

6. Polvpogon monspeliensis

7. Potentilla biennis

8. Verbena bracteata

9. Veronica anagallis-aguatica

10.
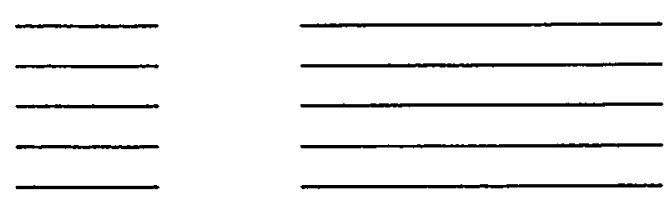

Other field indicators:

Percentage of species that are OBL, FACW, and/or FAC: $100 \%$; Hydrophytic vegetation: Yes $X$

Basis: A dominance of hydrophytic plants occurs at the observation point. Size of wetland was estimated at about $500 \mathrm{~m}^{2}$.

\section{Hydric Soils}

Field indicators: Hydric soils exist based on the presence of saturated soils for a period of 7 days or greater duration.

\author{
Hydric Soils: Yes \\ Jurisdictional Wetland Determination : Wetland
}

\section{Notes:}

Artemisia tridentata, Ericameria nauseosa encroaching on edge of wetland. A large water tank exists near lower end of the spring channel. On 6-18-96, water flowed $170 \mathrm{~m}$ down the wash to the old water tank. ${ }^{2}=$ Wetlands indicator status for plants in region 8 . $\mathrm{Tr}=$ Trace amounts $(<1 \%$ cover). OBL $=$ Obligate wetland species. FAC, FACW FACW + are all types of facultative wetland species. FACU = Facultative upland species. NL = not listed in National List of Plants that occur in Wetlands for Region 8. 


\section{Routine Jurisdictional Wetland Determination}

Name:

PDG, AA

Location: Tongue Wash Tank

Date:
Wetland Unit:_ Rock water tank in cave

UTM Coordinates Easting: 5-71-360 Northing: 41-13-050

\section{Hydrology}

Type: Seep Spring ___ Pond Detention basin Stream Natural tank $\mathrm{X}$ Source: Natural $X$ Man-enhanced __ Man-made __ Ephemeral __ Permanent $X$ Temporary Date of construction/Period of flow: It is unknown if water flows out of the tank during any time.

Disturbance type (if any) and date: None Depth of standing water_20-25cm ; Saturated: Yes_ $\mathrm{X}$ No__ Depth to saturation $\quad 0$

Other field indicators: A dark water mark on the rocks indicate a previous water level that is higher than the present water level.

Atypical situation: Yes $\quad$ No $\mathrm{X}$; $\quad$ Wetland hydrology: Yes $\mathrm{X}$ No_

Basis: Surface water exists at the observation point.

Vegetation List 3 dominant species, percent cover in bold, in each vegetation layer (5 if only 1 or 2 layers are present)

Trees Species

Indicator Status ${ }^{a}$

$\%$ Cover

1. none

2.

3.

4.

5.
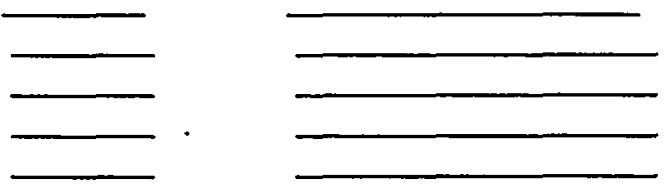

Shrubs

1. none

2.

3.

4.

5.

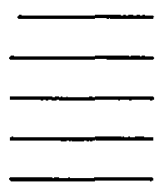

\section{Herbs}

1. none

2.

3.

4.

5.

6.

7.

8.

9.

10.

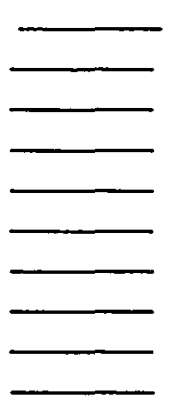

Other field indicators: Some grasses and annuals exist in a small unsaturated area $\left(2-3 \mathrm{~m}^{2}\right)$ below the cave opening where water may seep out or overflow the tank during very wet years.

Percentage of species that are OBL, FACW, and/or FAC:

\%; Hydrophytic vegetation: Yes No $\quad \mathrm{x}$

Basis: Hydrophytic vegetation is absent at the observation point

\section{Hydric Soils}

Field indicators: Hydric soils appear to be absent at the observation point because water is confined to a bedrock pool. No soil pits were dug at this site.

Hydric Soils: Yes No Nonwetland $\mathrm{X}$

Notes:

Jurisdictional Wetland Determination: Wetland

The water tank measures about $1-2 \mathrm{~m}$ wide by $3-4 \mathrm{~m}$ long and occurs in a small natural cave in tuff rock formation. Numerous petroglyphs at the site indicate use by Native Americans. Large numbers of birds were observed entering the cave drinking on 9-10-96. $=$ Wetlands indicator status for plants in region 8 . 


\section{Routine Jurisdictional Wetland Determination}

Name: PDG. JAA

Location: Topopah Spring

Wetland Unit:Cave Pool

Date: $\quad$ 6-20-96

UTM Coordinates Easting: $\underline{5-65-024}$ Northing: $\underline{40-88-369}$

\section{Hydrology}

Type: Seep _ Spring $\mathrm{X}$ Pond __ Detention basin Stream ___ Mechanically contained
Source: Natural $X$ Man-enhanced $X$ Man-made
Ephemeral Permanent $\mathrm{X}$ Temporary

Date of construction/Period of flow:Unknown

Disturbance type (if any) and date:Pipe was installed in the ground below the cave pool and has flow. Fire burned the area around the spring - date unknown: Cave pool was dug out to increase access to water. Dates of disturbance unknown. Inundated:Yes $X$ No__ Depth of standing water $15-20 \mathrm{~cm}$; Saturated: Yes $X$ No__ Depth to saturation 0 Other field indicators:

Atypical situation: Yes_ No $\mathrm{X}_{2}$ _ Wetland hydrology: Yes $\mathrm{X}$ No Basis: Surface water exists at the observation point. Total area of wetland (all habitats combined) estimated at about $200 \mathrm{~m}^{2}$. Flow rate measured from an existing pipe was estimated at $0.140 \mathrm{~L} / \mathrm{min}$ on September 91996.

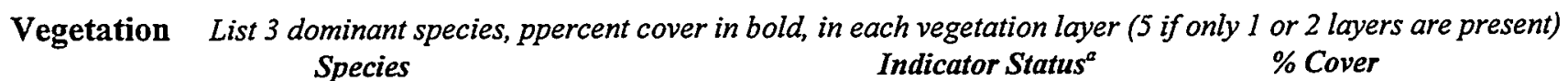

Trees nocies
1. none
2.
3.
4.
5.

Indicator Status ${ }^{a}$
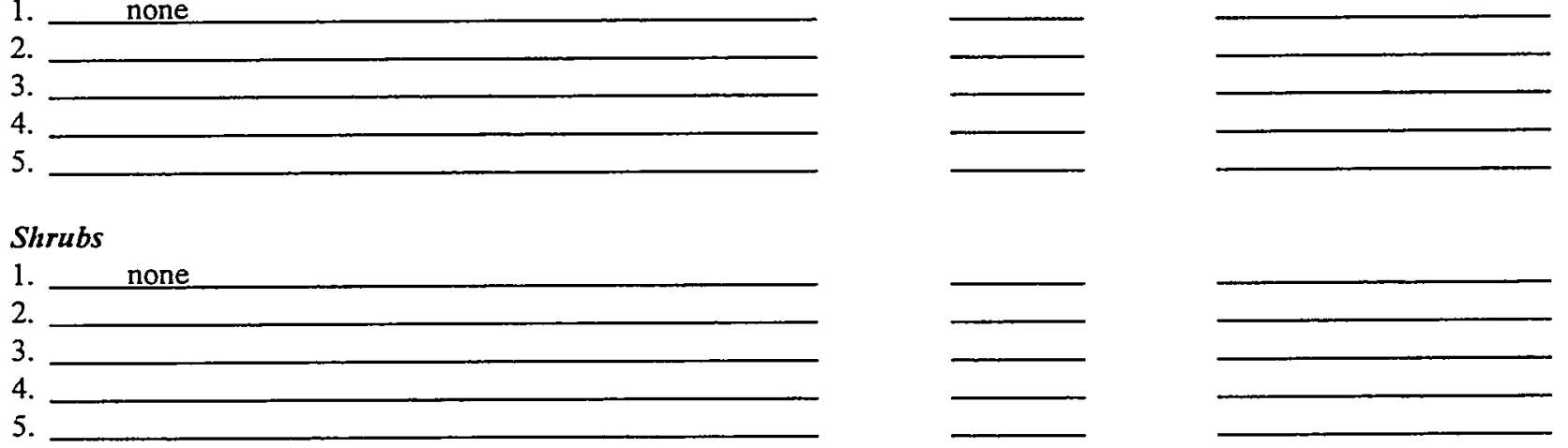

\section{Herbs}

2. Bromus diandrus

3. Epilobium glaberrimum

4. Mimulus guttatus

5. Polypogon monspeliensis

6. Potentilla biennis

7. Rumex salicifolius

8. Sisvmbrium altissimum

9. Veronica anagallis-aquatica

10. Pseudognaphalium stramineum
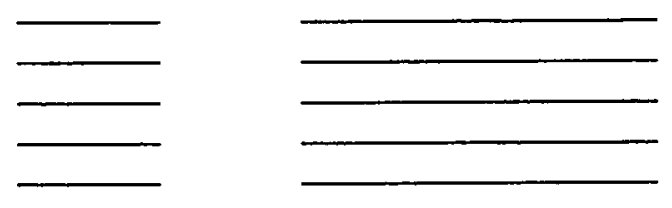

Other field indicators:

Percentage of species that are OBL, FACW, and/or FAC: $100 \%$; Hydrophytic vegetation: Yes $\mathrm{X}$ No

Basis: Hydrophytic vegetation is present at the observation point.

\section{Hydric Soils}

Field indicators: Hydric soils exist based on the presence of saturated soils for a period of 7 days or greater duration.

\begin{tabular}{l}
$\frac{\text { FACU }}{\text { NL }}$ \\
\hline FACW \\
\hline OBL \\
\hline FACW+ \\
\hline FAC \\
\hline FACW* \\
\hline FACU- \\
\hline OBL \\
\hline FAC
\end{tabular}

\begin{tabular}{l}
$\frac{5}{1}$ \\
\hline 5 \\
\hline 10 \\
\hline$\frac{1}{2}$ \\
$\frac{15}{1}$ \\
\hline$\frac{20}{5}$ \\
\hline
\end{tabular}

Hydric Soils: Yes

Jurisdictional Wetland Determination : Wetland $\mathrm{X}$ Nonwetland

\section{Notes:}

A pipe was installed into the ground which forms a second shallow pool with vegetation 10 meters downslope from the cave pool. ${ }^{\mathrm{a}}=$ Wetland indicator status for plants in region $8 . \mathrm{OBL}=$ Obligate wetland species. FAC, FACW, FACW + are all types of facultative wetland species. FACU. FACU- are both Facultative upland species. $*=a$ tentative assignment to this category based on limited information for this species. NL = not listed in the National List of Plants that occur in Wetlands for Region 8. 


\section{Routine Jurisdictional Wetland Determination}

Name: PDG, JAA

Location: Topopah Spring

Date: 6-20-96

\section{Hydrology}

Type: Seep __ Spring $\mathrm{X}$ Pond __ Detention basin Source: Natural $X$ Man-enhanced $X$ Man-made

Wetland Unit: 2 - Meadow/hillside wetland

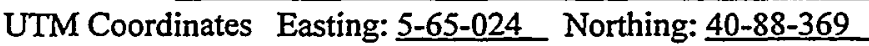

Date of construction/Period of flow: Unknown

Disturbance type (if any) and date: $6 \times 6 \mathrm{ft}$ pit dug on hillside-pipe installed by man to direct flow to tanks, presently not functional Inundated:Yes $X$ No__ Depth of standing water $2-5 \mathrm{~cm}$; Saturated: Yes $\underline{X}$ No_ Depth to saturation 0 Other field indicators: Pit dug out at the top of the hillside meadow (Dimensons of pit $=6 \times 6 \mathrm{ft}$.)
Atypical situation:
Yes
No $\mathrm{X} ;$;
Wetland hydrology:
Yes $\mathrm{X}$ No

Basis: Surface water is present at the observation point. Water was flowing (not measured) down the slope of the meadow.

Vegetation 3 dominant species, percent cover in bold, in each vegetation layer ( 5 if only 1 or 2 layers are present)

Indicator Status

$\%$ Cover

Trees

1.

2.

3.

none

\section{Shrubs}

1. none

2.

3.

\section{Herbs}

1. Agrostis exarata var monolepis

2. Artemisia ludoviciana

3. Bromus diandrus

4. Carex praegracilis

5. Castillejasp.

6. Conyza canadensis

7. Eleocharis parishii

8. Epilobium glaberrimum

9. Erigeron divergens

10. Juncus balticus

11. Juncus saximontanus

12. Lactuca serriola

13. Mimulus guttatus

14. Poa secunda

15. Polvpogon monspeliensis

16. Potentilla biennis

17. Pseudognaphalium stramineum

Other field indicators:

Percentage of species that are OBL, FACW, and/or FAC: $>50 \quad \%$; Hydrophytic vegetation: Yes_X No

Basis: Frequency method was employed at this site: Total percent cover of wetland species summed (63\%) exceeds total cover by non-wetland plant species (41\%). A dominance of hydrophytic species exists at the observation point.

Hydric Soils:

Field indicators: Hydric soils exist based on the presence of surface hydrology and hydrophytic vegetation.

Hydric Soils: Yes $\mathrm{X}$

\section{Notes:.}

Jurisdictional Wetland Determination : Wetland _ $\mathrm{X}$ Nonwetland

An area of surface inundation near the bottom of the slope was about $6 \mathrm{ft}$. long by $3 \mathrm{ft}$. wide. Another inundated spot near top of the slope was $8 \mathrm{ft}$. wide $\times 3 \mathrm{ft}$. long. Saturated soils are about $20 \mathrm{~m}$ long by $3-4 \mathrm{~m}$ wide. Soils were dark grey, with little organic matter and no mottling was detected. Wetland vegetation on the sloped meadow is about $20 \times 6 \mathrm{~m}$ in dimensions. $a=$ Wetlands plant indicator status for region 8 . OBL $=$ Obligate wetland species, FAC, FACW, FACW + - are all types of facultative wetland species. FACU = Facultative upland plants. $\mathrm{NL}=$ not listed in the National List of Plants that occur in Wetlands for Region 8. 


\section{Routine Jurisdictional Wetland Determination}

Name: WKO

Wetland Unit: Wash

Location:Tupapa Seep

UTM Coordinates Easting: 5-82-242 Northing: 40-66-431

Date: $\quad 11-7-96$

\section{Hydrology}

Type: Seep $\mathrm{X}$ Spring ___ Pond Detention basin Stream Mechanically contained

Source: Natural $X$ Man-enhanced Man-made Ephemeral $\bar{X}$ Permanent Temporary

Date of construction/Period of flow: Unknown period of flow.

Disturbance type (if any) and date: None

Inundated:Yes - No $X$ Depth of standing water 0 ; Saturated: Yes No $\underline{X}$ Depth to saturationUnknown

Other field indicators:

Atypical situation: Yes__ No $\mathrm{X}$ _ $; \quad$ Wetland hydrology: Yes__ No__ X

Basis: No field indicators of surface hydrology were detected but the survey was performed in a very dry year.

Vegetation List 3 dominant species, percent cover in bold, in each vegetation layer (5 if only 1 or 2 layers are present)

Trees nocies
1. none
2.
3.
4.
5.

Indicator Status ${ }^{a} \quad \%$ Cover

\section{Shrubs}

1. Atriplex confertefolia

2. Salazaria mexicana

3. Ericameria nauseosa

4.

5.

\section{Herbs}

1. Hordeum jubatum

2. Bromus tectorum

3.

4.

5.

6.

7.

8.

9.

10.
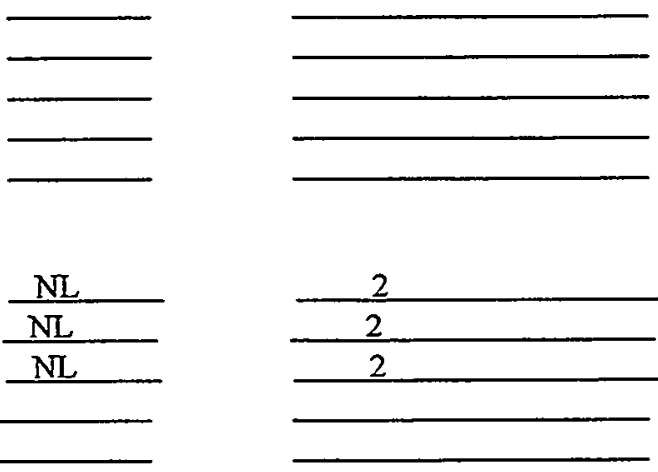

Other field indicators:

Percentage of species that are $\mathrm{OBL}, \mathrm{FACW}$, and/or $\mathrm{FAC}: 50 \%$; Hydrophytic vegetation: Yes
Basis: Only a weak indication of dominance of hydrophytic vegetation was shown at the observation point
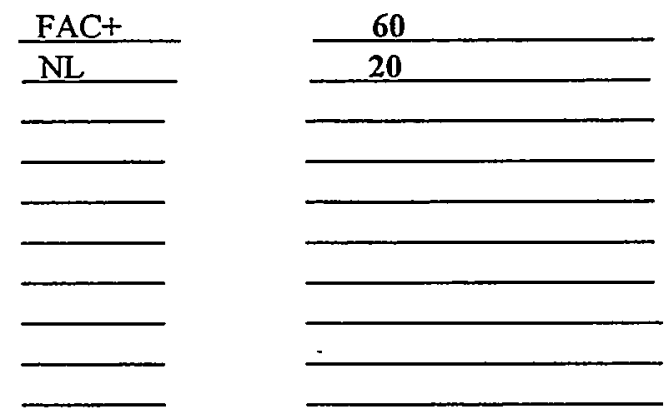

Hydric Soils

Field indicators: No indicators of hydric soils were detected at the observation point.

Hydric Soils: Yes No

Jurisdictional Wetland Determination : Wetland Nonwetland $\mathrm{X}$

\section{Notes:}

Large unidentified composite - toothed leaves 4-5 ft. high. Animal use - coyote scats - raven flew over on survey date. ${ }^{2}$ Wetland indicator status for plants in region 8 . FAC $+=$ Facultative wetland species. NL $=$ not listed in National List of Plants that occur in Wetlands for Region 8. 


\section{Routine Jurisdictional Wetland Determination}

Name: PDG

Location:Tub Spring

Date: 6-24-96

\section{Hydrology}

Type: Seep__ Spring $\mathrm{X}$ Pond Detention basin Stream Mechanically contained Source: Natural _ Man-enhanced $\mathrm{X}$ Man-made $\mathrm{X}$ Ephemeral _ Permanent $\mathrm{X}$ Temporary Date of construction/Period of flow: A tunnel was dug into hillside to increase access to water. Date of excavation unknown. Metal pipes were installed to direct water to a metal tank $60 \mathrm{~m}$ downslope in the wash. Maintenance of a clogged pipe was performed in 1975 to increase flow. The metal pipe was observed disconnected in 1988 and the tank was dry at this time. Disturbance type (if any) and date: Water drips from a broken pipe that comes from the tunnel pool to a gallon tin can which was emplaced into the ground after 1992. Water overflows the can and wets a small area on the ground. A flow rate of 0.06 $\mathrm{L} / \mathrm{min}$ was measured from an existing pipe on September 10,1996. Inundated:Yes $\mathrm{X}$ No _. Depth of standing water $8^{\prime \prime}$ in can; Saturated: Yes $\mathrm{X}$ No _ Depth to saturationUnknown Other field indicators: Depth of water on soil was approximately 1 inch $(2-3 \mathrm{~cm})$ covering about $1 \mathrm{~m}^{2}$ surface area. Atypical situation: Yes__ No _ Basis: Tunnel that was excavated by man has water about $1 \mathrm{ft}$ deep, and a pipe carries water about $60 \mathrm{~m}$ down a dry wash to a shallow surface pool.

Vegetation List 3 dominant species, percent cover in bold, in each vegetation layer ( 5 if only 1 or 2 layers are present) Species

Indicator Status $\%$ Cover

\section{Trees}

1. none

2.

3.

4.

5.

\section{Shrubs}

1. Rhus trilobata

2.

3.

4.

5.

\section{Herbs}

1. unidentified grass

2.

3.

4.

5.

6.

7.

8.

9.

10.

Other field indicators: Tunnel excavation may have altered water availability at the original spring site impacting any hydrophytic vegetation present. A rockslide occurred in 1975 that may have impacted original spring site. Percentage of species that are OBL, FACW, and/or FAC: 0 _ \%; Hydrophytic vegetation: Yes__ No__ Basis: No hydrophytic vegetation was present at the observation point.

Hydric Soils:

Field indicators: Hydric soils are present in the cave based on presence of saturated soils for greater than 7 days duration. 


\section{Routine Jurisdictional Wetland Determination}

Name: WKO

Wetland Unit: Wash

Location:Tupapa Seep

UTM Coordinates Easting: 5-82-242 Northing: 40-66-431

Date: $\quad 11-7-96$

\section{Hydrology}

Type: Seep $X$ Spring ___ Pond Detention basin Stream Mechanically contained

Source: Natural $X_{\text {_ }}$ Man-enhanced Man-made __ Ephemeral $\mathrm{X}$ Permanent Temporary

Date of construction/Period of flow: Unknown period of flow.

Disturbance type (if any) and date: None

Inundated:Yes _ No_X Depth of standing water _ 0 ; Saturated: Yes__ No $\underline{X}$ Depth to saturation Unknown Other field indicators:

Atypical situation: $\quad$ Yes__ No $\mathrm{X}$ _ $;$ Wetland hydrology: Yes__ No_ X

Basis: No field indicators of surface hydrology were detected but the survev was performed in a very dry year.

Vegetation List 3 dominant species, percent cover in bold, in each vegetation layer ( 5 if only 1 or 2 layers are present)

Trees nocies
1.
2.
3.
4.
5.

Indicator Status ${ }^{a} \quad \%$ Cover

\section{Shrubs}

1. Atriplex confertefolia

2. Salazaria mexicana

3. Ericameria nauseosa

4.

5.

\section{Herbs}

1. Hordeum jubatum

2. Bromus tectorum

3.

4.

5.

6.

7.

8.

9.

10.

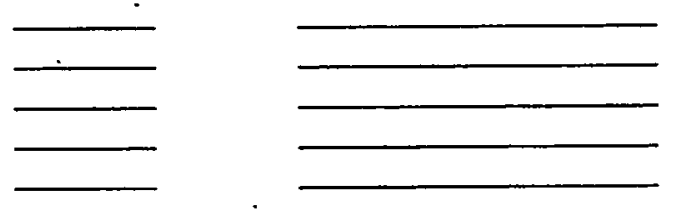

\begin{tabular}{l}
$\frac{2}{2}$ \\
\hline 2 \\
\hline
\end{tabular}
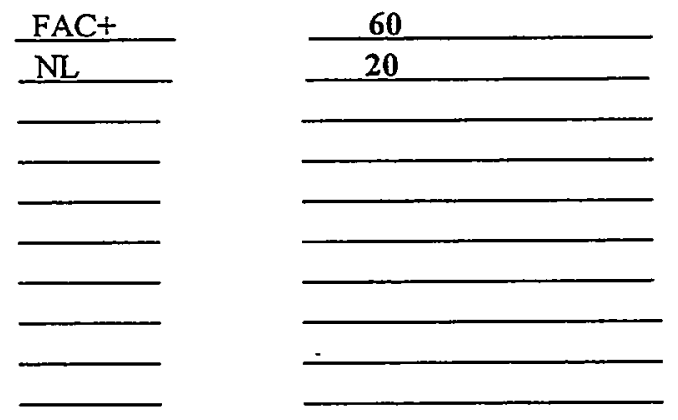

Other field indicators:

Percentage of species that are OBL, FACW, and/or FAC: $50 \%$; Hydrophytic vegetation: Yes __ No _ X

Basis: Only a weak indication of dominance of hydrophytic vegetation was shown at the observation point.

Hydric Soils

Field indicators: No indicators of hydric soils were detected at the observation point.

$$
\text { Hydric Soils: Yes }
$$
No

Jurisdictional Wetland Determination : Wetland Nonwetland

\section{Notes:}

Large unidentified composite - toothed leaves $4-5 \mathrm{ft}$. high. Animal use - coyote scats - raven flew over on survev date. ${ }^{a}$ Wetland indicator status for plants in region 8 . FAC $+=$ Facultative wetland species. NL $=$ not listed in national list of plants that occur in wetlands for region 8 . 


\section{Routine Jurisdictional Wetland Determination}

Name: PDG, WKO

Location:Twin Springs

Date: $\quad 12-19-96$

\section{Hydrology}

Type: Seep Spring $\mathrm{X}$ Pond Detention basin Stream Mechanically contained Source: Natural $X$ Man-enhanced Man-made Ephemeral Permanent $\mathrm{X}$ Temporary

Date of construction/Period of flow: Unknown

Disturbance type (if any) and date: Tunnel was dug into hillside $15-18 \mathrm{~m}$ by man. A cave-in has occurred. No water visible in cave, but soils are saturated. Tailings excavated from cave form a terrace on hillsidewith stone structure/foundation on it. Inundated:Yes $X$ No _ Depth of standing water $10 \mathrm{~cm}$; Saturated: Yes $X$ No__ Depth to saturation 0 Other field indicators: Outside pool of water exists below a rock ledge.

Atypical situation: Yes_ No $\mathrm{X}$; Basis:__ Surface water occurs at the observation point.

Wetland hydrology: Yes $\underline{X}$ No

Vegetation List 3 dominant species, \% cover in bold, in each vegetation layer ( 5 if only 1 or 2 layers are present)

Trees

Species

Indicator Status ${ }^{a}$

\% Cover

1.

2.

3.

4.

5.

\section{Shrubs}

1.

2.

3.

4.

5.

\section{Herbs}

1. Polypogon monspeliensis

2. Rumex salicifolius

3. Tvpha domingensis

4.

5.

6.

7.

8.

9.

none

Percentage of species that are OBL, FACW, and/or FAC: $100 \%$; Hydrophytic vegetation: Yes $\mathbf{X}$ No Basis: The observation point has a dominance of hydrophytic vegetation. Size of the wetland estimated at about $27 \mathrm{~m}^{2}$

Hydric Soils

Field indicators: Hydric soils exist based on the presence of saturated soils for a period of 7 or more days duration.

Hydric Soils: Yes_ $\mathrm{X}$ No

Jurisdictional Wetland Determination: Wetland $\underline{\mathrm{X}}$ Nonwetland

Notes:

Artemesia dracunculus (NL). A ludoviciana (Facu), and Rhus trilobata (ND) occur on the edges of the wetland habitat. $R$. trilobata occupied about $50 \%$ of the wetland edge area. ${ }^{2}$ Wetland indicator status for plants in region 8. OBL = Obligate wetland species. FACW $+=$ a facultative wetland species. FACW* refers to a tentative assignment of this species to a facultative wetland category based on limited information in region $8 . \mathrm{Tr}=$ trace amounts $(<1 \%$ cover $)$. 


\section{Routine Jurisdictional Wetland Determination}

Name: PDG, DJH, JAA

Wetland Unit: 1 - Upper stretch of spring channel

Location: Whiterock Spring UTM Coordinates Easting: 5-77-015 Northing: $41-17-396$

Date: $\quad$ 6-18-96

\section{Hydrology}

Type: Seep _ Spring $X$ Pond Detention basin

Stream Mechanically contained Source: Natural $X$ Man-enhanced $X$ Man-made __ Ephemeral _ Permanent X Temporary Date of construction/Period of flow: Flow gauge box has water directed to it through PVC pipes from two tunnels (adits) excavated by man. Unknown date of tunnel excavations.

Disturbance type (if any) and date: A cement retaining wall (3-4 "high) was constructed at the entrance to the east cave with a pipe for drainage to the outside. Date of construction unknown. Inundated:Yes $X$ No Depth of standing water $8-10 \mathrm{~cm}$ in Caves; Saturated: Yes $\underline{X}$ No__ Depth to saturation 18 inches Other field indicators: A broken pipe from the east cave allows water to form a small shallow (1" deep) pool outside the cave entrance. Flow rate from both caves combined was estimated to be about $1.9 \mathrm{~L} / \mathrm{min}$ on September 3, 1996.

Atypical situation: Yes $\quad$ No $\quad \mathrm{X}$; Wetland hydrology: Yes $\mathrm{X}$ No Basis: Surface water occurs at the observation point. Gravelly soils allow quick drainage of spring flow to subsurface levels of the soil stratum.

Vegetation List 3 dominant species, percent cover in bold, in each vegetation layer (5 if only 1 or 2 layers are present)

Trees Species
1.
2.
3.
4.
Indicator Status ${ }^{a}$ $\%$ Cover

\section{Shrubs}

1. Salix exigua

2.

3.

4.
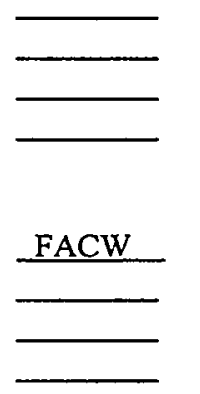

80
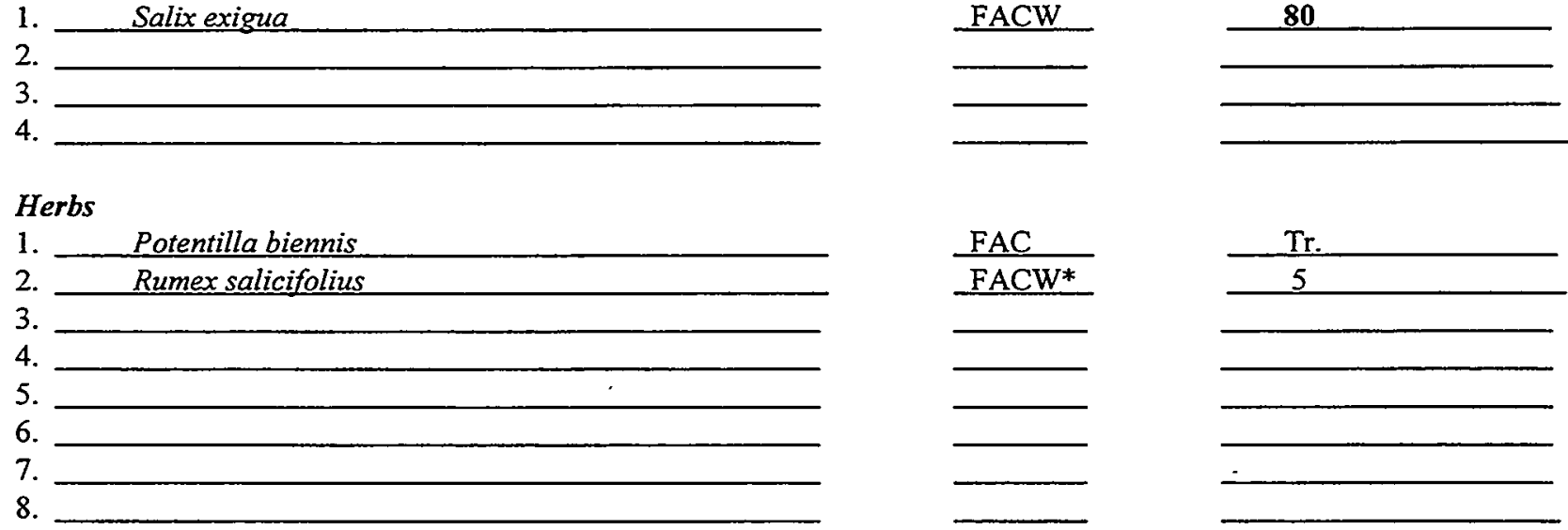

Other field indicators:

Percentage of species that are OBL, FACW, and/or FAC: $100 \quad \%$; Hydrophytic vegetation: Yes $\mathrm{X}$ No Basis: A dominance of hydrophytic vegetation occurs at the observation point.

Hydric Soils

Field indicators: Hydric soils exist based on the presence of saturated soils for 7 days or longer duration at the observation point.

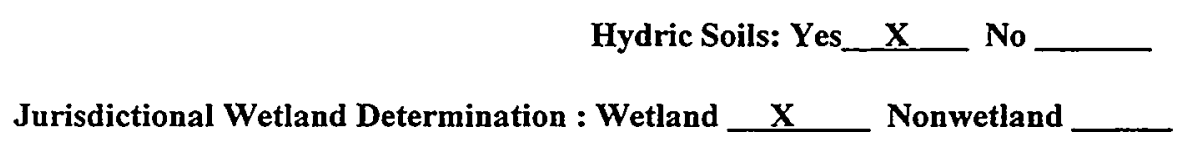

Notes:

Salix exigua stand measures about $70 \mathrm{~m}$ by $20-30 \mathrm{~m}$ across. Artemisia ludoviciana and Ericameria nauseosa are encroaching on the edge of the delineated area. Limited surface water; Salix shrubs $\approx 10 \mathrm{ft}$. high $(3 \mathrm{~m})-$ Rhus trilobata is possibly spread by birds. Willow trees provide considerable cover for birds and wildlife. ${ }^{2}$ Wetland indicator status for plants in region 8. FACW $=$ Facultative wetland species. FAC $=$ Facultative wetland species. ${ }^{*}$ refers to a tentative assignment to a category based on limited information in region $8 . \mathrm{Tr}=\mathrm{Trace}$ amgunts $(<1 \%$ cover $)$ 


\section{Routine Jurisdictional Wetland Determination}

Name: PDG, DJH, JAA

Location: Whiterock Spring

Date: 6-18-96
Wetland Unit: 2 - Lower stretch of spring channel

UTM Coordinates Easting: 5-77-015 Northing: 41-17-396

\section{Hydrology}

Type: Seep ___ Spring $\underline{X}$ Pond

Source: Natural $X$ Man-enhanced

Detention basin

Stream Mechanically contained

Date of construction/Period of flow:Unknown

Disturbance type (if any) and date: Old remnants of livestock corral present in lower section of the wash - Broken down Inundated:Yes - NoX Depth of standing water 0 ; Saturated: Yes _ No X Depth to saturation unknown Other field indicators: Dried algae in stream channel/pools - rocky soil - very few fines.
Atypical situation:
Yes
No $\mathrm{X}$;
Wetland hydrology: Yes $\mathrm{X}$ No

Basis: Evidence of surface hydrology exists at the observation point.

Vegetation List 3 dominant species, percent cover in bold, in each vegetation layer ( 5 if only 1 or 2 layers are present)

Trees Species
1. none
2.
3.
4.
5.

Indicator Status

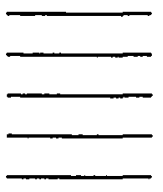

Shrubs

1. none

2.

3.

4.

5.

\section{Herbs}

1. Artemisia ludoviciana

2. Juncus balticus

3. Linum lewisii

4. Potentilla biennis

5. Rumex salicifolius

6. Sporobolus airoides.

7.

8.

9.

10.

Other field indicators:

Percentage of species that are OBL, FACW, and/or FAC: $100 \%$ Hydrophytic vegetation: Yes $\mathrm{X}$ No

Basis: A dominance of hydrophytic vegetation occurs at the observation point. Total area of wetland (upper and lower stretches of the habitat combined) was estimated to be about $1800 \mathrm{~m}^{2}$

Hydric Soils:

Field Indicators: Hydric soils exist based on the presence of saturated soils for greater than 7 days at the observation point.

\author{
Hydric Soils: Yes \\ $\mathrm{X}$ No \\ Jurisdictional Wetland Determination : Wetland \\ Nonwetland
}

FACU

FACW

NL

FAC

FACW*

FAC-
$\%$ Cover
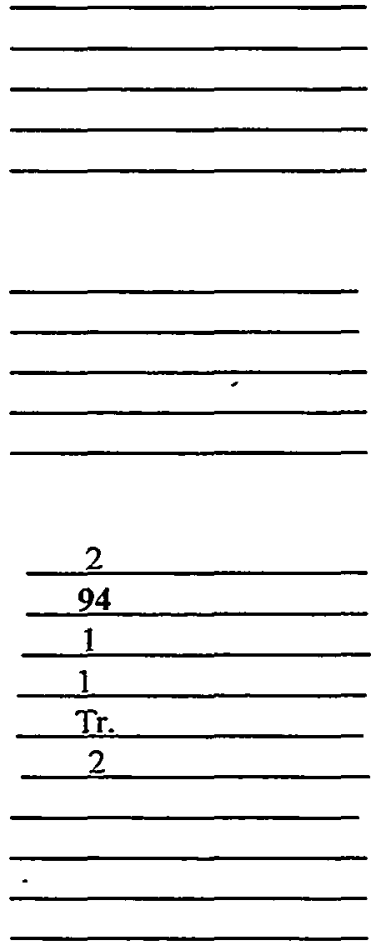

Notes:

Ericameria nauseosa is encroaching on the edge of the wash. Surface area of Juncus balticus measures about $70 \mathrm{~m}$ by $3 \mathrm{~m}$. Pools in lower section of the wash have dried algae on rocks. This site was wet, inundated in the lower reaches earlier this year. 2 Wetland indicator status for plants in region 8. FAC. FACW, are both facultative wetland species. FACU = Facultative upland species. ${ }^{*}$ refers to a tentative assignment of a species to a category based on limited information in region 8 . $\operatorname{Tr}=$ Trace amounts ( $<1 \%$ cover). NL= not listed in National List of Plants that occur in Wetlands for Region 8. 


\section{Routine Jurisdictional Wetland Determination}

Name: Yellow Rock Springs

Location: PDG, WKO

Date: 12-19-96

\section{Hydrology}

Type: Seep _ Spring $X$ Pond Source: Natural $X$ Man-enhanced Detention basin Stream Mechanically contained Date of construction/Period of flow: None/ Unknown season of flow Disturbance type (if any) and date: None Depth of standing water $2-30 \mathrm{~cm}$; Saturated: Yes $\mathrm{X}$
Other field indicators: Wetland Unit:_ Rocky Wash UTM Coordinates Easting: 555-979 Northing:4-091-944

Other field indicators: Water seeps out of the tuff in several locations. Three separate channels have water flow.

Atypical situation: Yes_ No $\mathrm{X}$; Wetland hydrology: Yes X $\mathrm{X}$ No Basis: ___ Pools of water were frozen over at time of survey. Flow was present, but was not measured.

Vegetation List 3 dominant species, percent cover in bold, in each vegetation layer (5 if only 1 or 2 layers are present)

\section{Trees} Species Indicator Status ${ }^{a}$ $\%$ Cover

1.

2.

3.

4.

5.

\section{Shrubs}

1. Rhus trilobata

2.

3.

4.

5.

\section{Herbs}

1.

2.

3.

4.

5.

6.

7.

8.

9.

10.
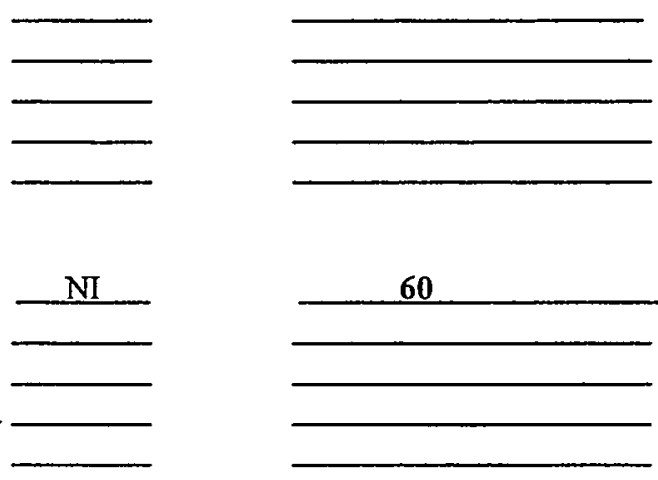

60
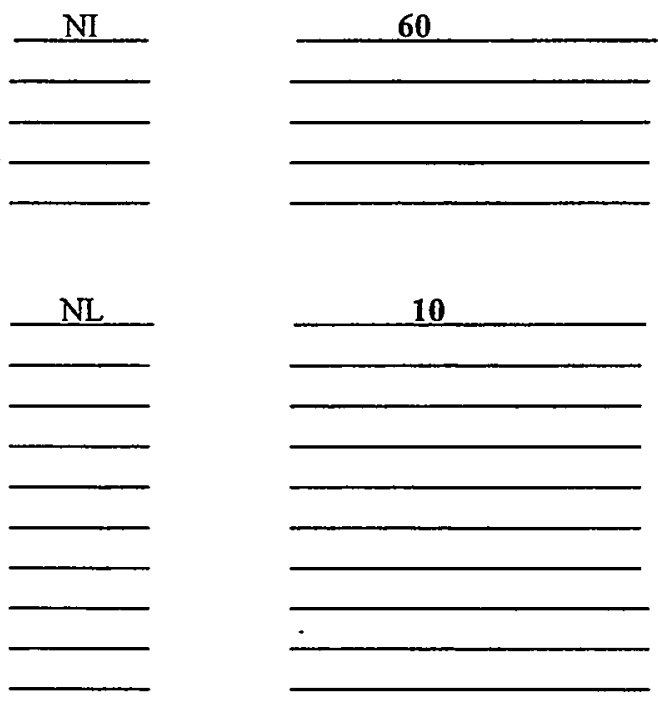

Other field indicators:

Percentage of species that are OBL, FACW, and/or FAC: $\quad 0 \quad \%$; Hydrophytic vegetation: Yes Basis: Hydrophytic vegetation was absent from the observation point.

\section{Hydric Soils}

Field indicators: Hydric soils appear to exist based on the presence of saturated soils for a period of 7 days or greater duration.

Hydric Soils: Yes_ $X$ No

Jurisdictional Wetland Determination : Wetland Nonwetland $\mathrm{X}$

Notes:

Water flows in three washes for about $40-60 \mathrm{~m}$ length. Inundated pools exist with some shallow gravelly soils. ${ }^{2}$ Wetlands indicator status for plants in region 8. NL $=$ not listed in the National List of Plants that occur in Wetlands for Region 8 . NI $=$ insufficient information to classify plants acording to wetlands status. 


\section{Routine Jurisdictional Wetland Determination}

Name: $\quad$ PDG, DJH

Wetland Unit: Plava Pond

Location: Yucca Playa Pond

UTM Coordinates Easting: 584-805 Northing:40-90-584

Date: $\quad 1-7-97$

\section{Hydrology}

Type: Seep _ Spring __ Pond $X$ Detention basin

Source: Natural $X$ Man-enhanced

Stream

Mechanically contained

Date of construction/Period of flow: Nonel unknown

Disturbance type (if any) and date: None

Depth of standing water $>100 \mathrm{~cm}$; Saturated: Yes $X$ No Ephemeral $X$ Permanent

Temporary

Other field indicators:

Atypical situation:

Yes

Depth to saturation_ surface

Inundated:Yes $\underline{X}$ No

Basis: Surface water is present at the observation point.

Vegetation List 3 dominant species, percent cover in bold, in each vegetation layer (5 if only 1 or 2 layers are present) Species

\section{Indicator Status ${ }^{a} \quad$ \% Cover}

\section{Trees}

1. Tamarix ramosissima

2.

3.

4.

5.

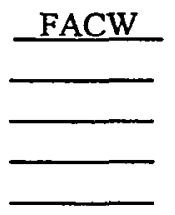

5

\section{Shrubs}

1.

2.

3.

4.

5.

\section{Herbs}

1. Typha domingensis

2.

3.

4.

5.

6.

7.

8.

9.

10.
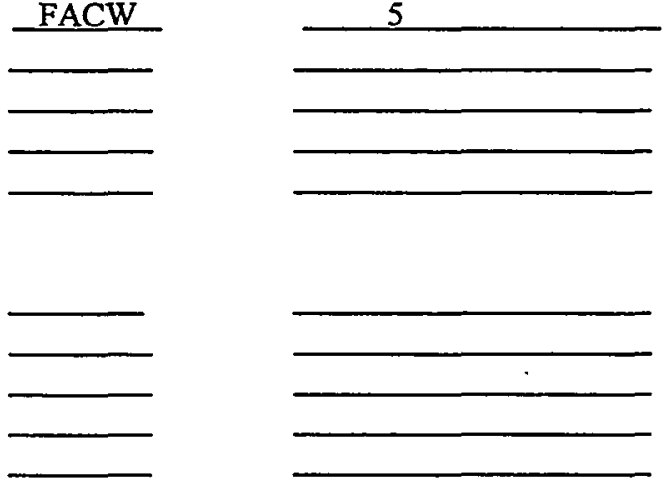

Other field indicators: About 50 Tamarix trees exist at the water source.

Percentage of species that are OBL, FACW, and/or FAC: $100 \%$; Hydrophytic vegetation: Yes $\mathbf{X}$ No

Basis: A dominance of hydrophytic plants occurs at the observation point. The wetland area was estimated to be about $3400 \mathrm{~m}^{2}$. including the area of plants and an equal area of rooting zone.

Hydric Soils

Field indicators:__ Hydric soils exist based on the presence of saturated soils for a period of 7 days or greater duration.

Hydric Soils: Yes_ $\mathrm{X}$ No

Jurisdictional Wetland Determination : Wetland

Notes:

Soils at the observation site have high silt content. The pond was frozen over at the time of the survey. ${ }^{a}$ Wetland indicator status for plants in region $8 . \mathrm{Tr} .=$ trace amounts $(<1 \%$ absolute cover). FACW $=$ Faculative wetland species. OBL $=$ Obligate wetland species. 
This Page Intentionally Left Blank 


\section{APPENDIX C}

LIST OF ALGAE AND ALGAE-LIKE SPECIES

IDENTIFIED FROM SPRINGS ON THE NEVADA TEST SITE 
Appendix C. List of algae and algae-like species identified from springs on the NTS.

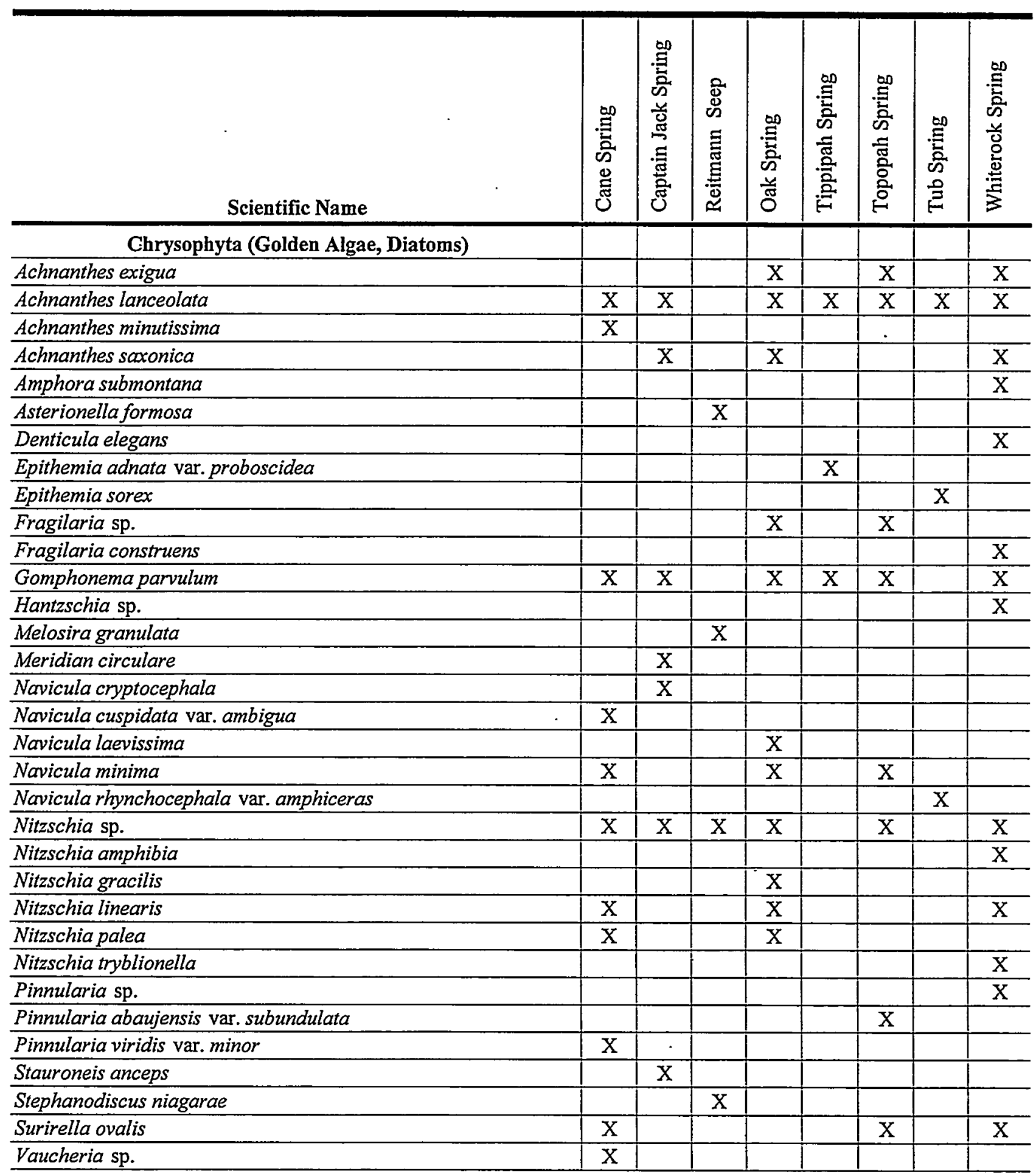

Sources: Shields and Drouet, 1962; Taylor and Giles, 1979 
Appendix C. List of algae and algae-like species identified from springs on the NTS.

\begin{tabular}{|c|c|c|c|c|c|c|c|c|}
\hline Scientific Name & 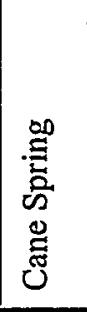 & 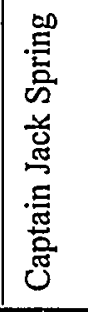 & 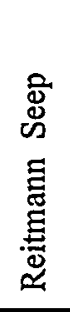 & $\begin{array}{l}\text { 是 } \\
\text { क } \\
\text { है } \\
0\end{array}$ & 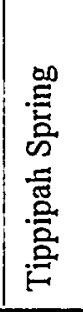 & 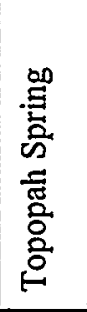 & 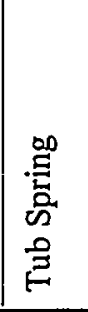 & 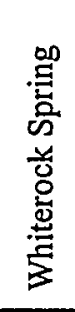 \\
\hline \multicolumn{9}{|l|}{ Chlorophyta (Green Algae) } \\
\hline Ankistrodesmus falcatus & & & $\mathrm{x}$ & & & & & \\
\hline Bulbochaete sp. & $\mathrm{x}$ & & & & & & & \\
\hline Chara sp. & $\mathrm{X}$ & & & & & & & \\
\hline Chlamydomonas sp. & & & & & & & & $\mathrm{X}$ \\
\hline Chlorella vulgaris & & $\mathrm{X}$ & $\mathrm{X}$ & & I & & & \\
\hline Closterium turgidum & & & & & & $\mathrm{X}$ & & \\
\hline Cosmarium sp. & & $\mathrm{X}$ & & & & & $\mathrm{X}$ & \\
\hline Franceia droescheri & $\bar{X}$ & & & & & & & \\
\hline Haematococcus lacustris & & & & $\mathrm{X}$ & & & & \\
\hline Microthamnion kuetzingianum & $\mathrm{X}$ & & & $\mathrm{X}$ & & & & \\
\hline Oedogonium sp. & $\mathrm{X}$ & $\mathrm{X}$ & & & & & & $\mathrm{X}$ \\
\hline Oocystis borgei & & & & $\mathrm{X}$ & & & & \\
\hline Oocystis crassa & $\mathrm{X}$ & & & & & & & \\
\hline Pandorina morum & $\mathrm{X}$ & & & & & & & \\
\hline Protoderma viride & & & & $\mathrm{X}$ & & & & \\
\hline Scenedesmus acutus & & & & $\mathrm{X}$ & & & & \\
\hline Scenedesmus bijuga & $\mathrm{X}$ & & & & & & & \\
\hline Spirogyra juergensii & & $\mathrm{X}$ & & & 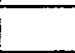 & & & \\
\hline Stigeoclonium sp. & $\mathrm{X}$ & $\mathrm{X}$ & & $\mathrm{X}$ & & & $\mathrm{X}$ & \\
\hline Ulothrix sp. & & & & $\mathrm{X}$ & & & & \\
\hline \multicolumn{9}{|c|}{ Cyanobacteria (formerly known as blue-green algae) } \\
\hline Amphithrix janthina & $\bar{X}$ & & & & & & & \\
\hline Calothix sp. & & $\mathrm{X}$ & & $\mathrm{X}$ & & & & \\
\hline Lyngbya sp. & & & & & & & & $\mathrm{X}$ \\
\hline Nodularia sphaerocarps & $\mathrm{X}$ & & & & & & & \\
\hline Nostoc enthophytum & $\mathrm{X}$ & & & & & & & \\
\hline Oscillatoria brevis & $\mathrm{X}$ & & & & & & & \\
\hline Oscillatoria sp. & & $\bar{X}$ & $\mathrm{X}$ & & & $\mathrm{x}$ & & \\
\hline Phormidium autumnale & $\mathrm{X}$ & & & & & & & \\
\hline Phormidium sp. & & & & & & & & $\mathrm{X}$ \\
\hline Phormidium tenue & $\mathrm{X}$ & & & & & & $\mathrm{X}$ & \\
\hline Plectonema boryanum & $\mathrm{X}$ & & & & & & & \\
\hline Total Number of Species & 27 & 14 & 7 & 19 & 3 & 10 & 6 & 19 \\
\hline
\end{tabular}

Sources: Shields and Drouet, 1962; Taylor and Giles, 1979 


\section{APPENDIX D}

\section{LIST OF ANIMALS DOCUMENTED TO OCCUR AT}

NTS WETLANDS AND THEIR SEASON OF USE 


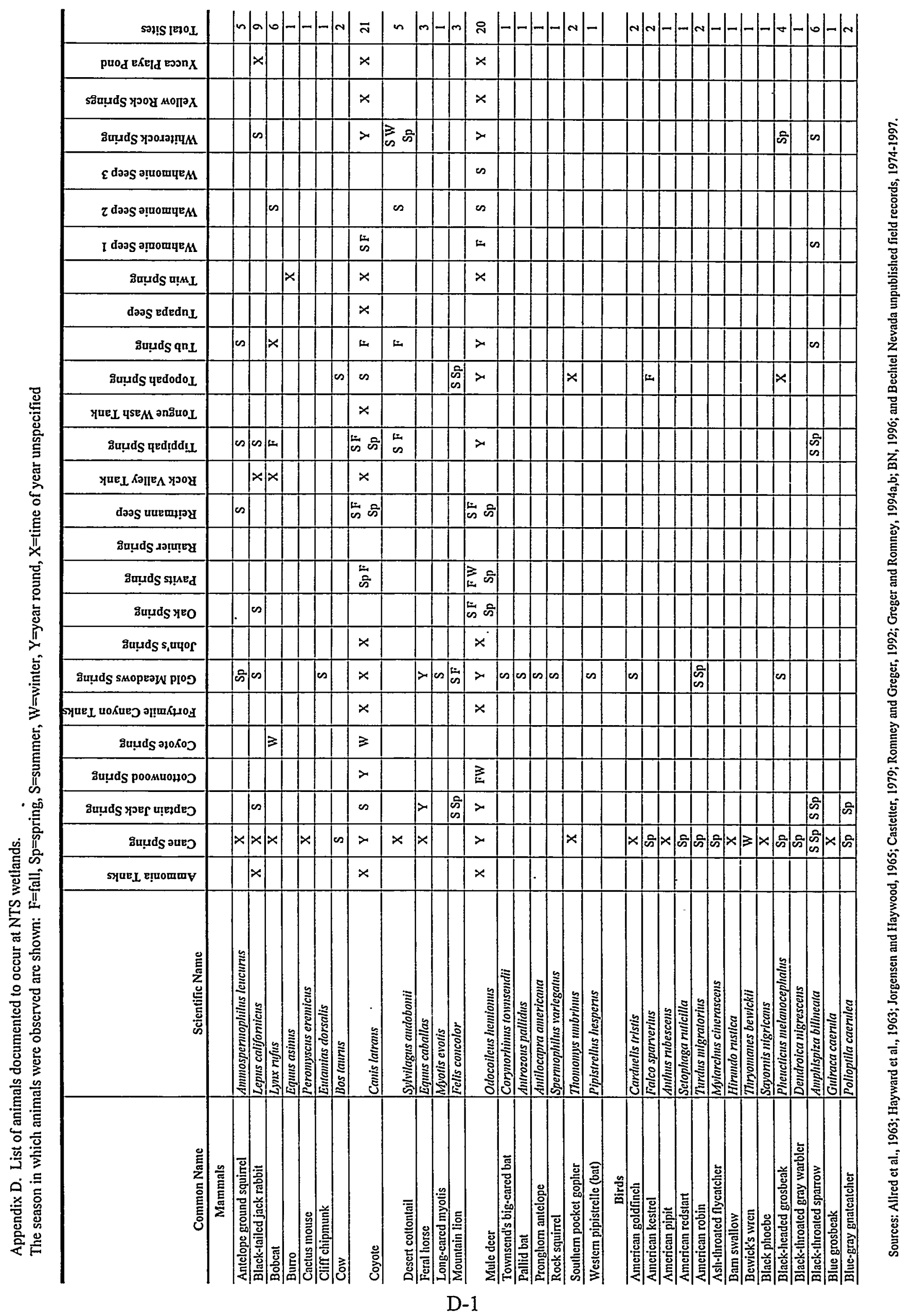




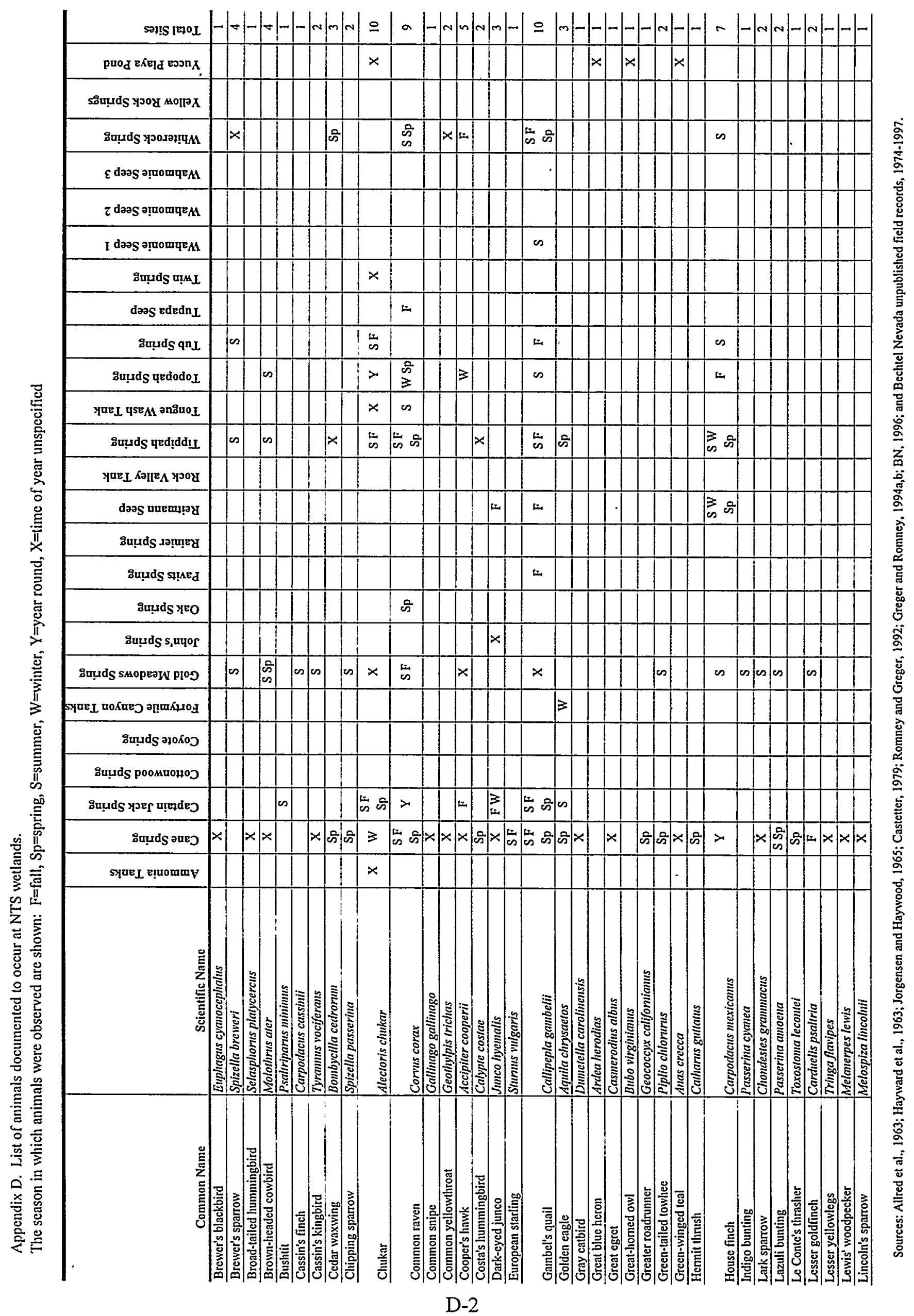




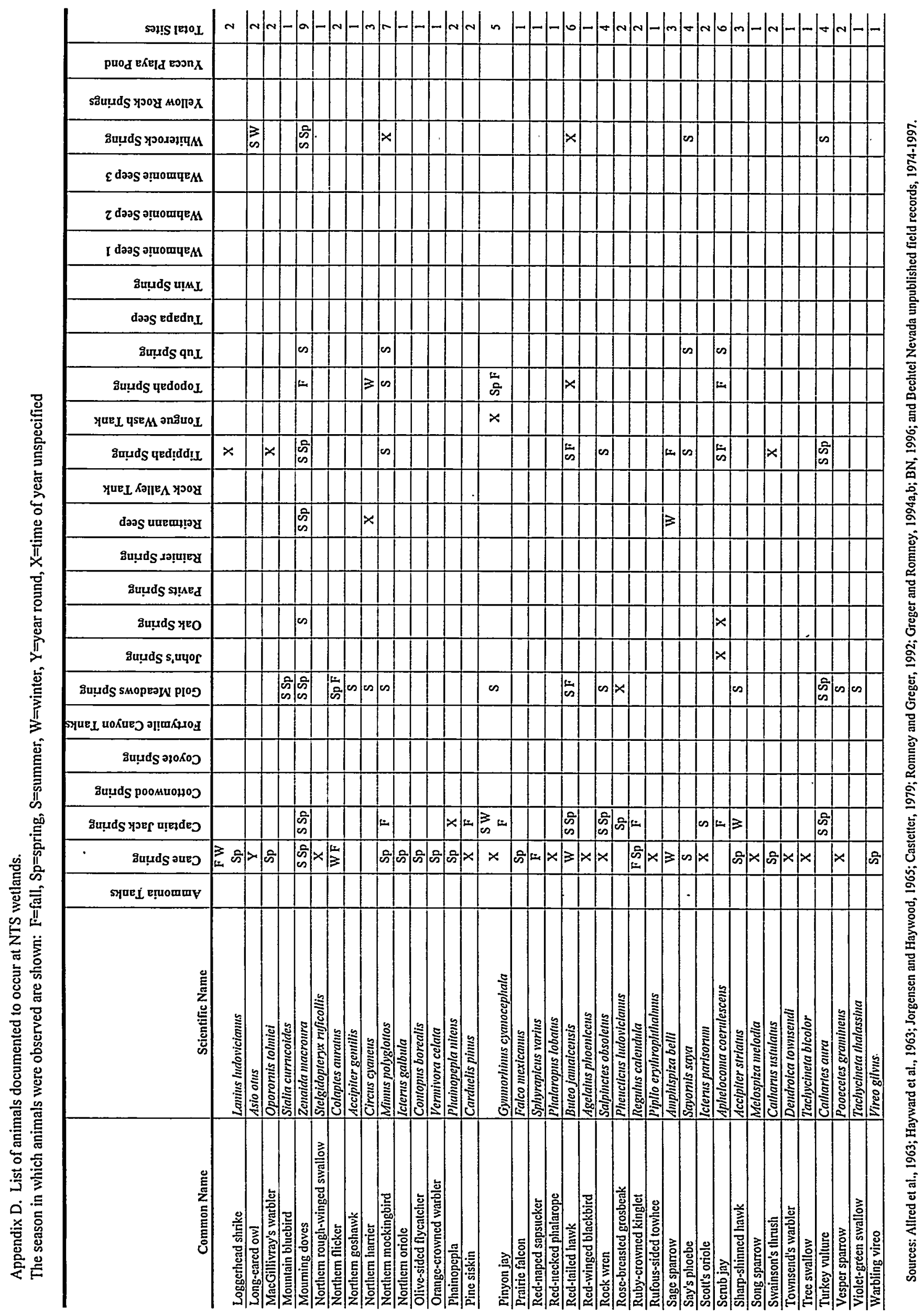

D-3 
Appendix D. List of animals documented to occur at NTS wetlands.

The season in which animals were observed are shown: $F=$ fall, $S p=$ spring, $S=$ summer, $W=$ winter, $Y=y e a r$ round, $X=$ time of year unspecified

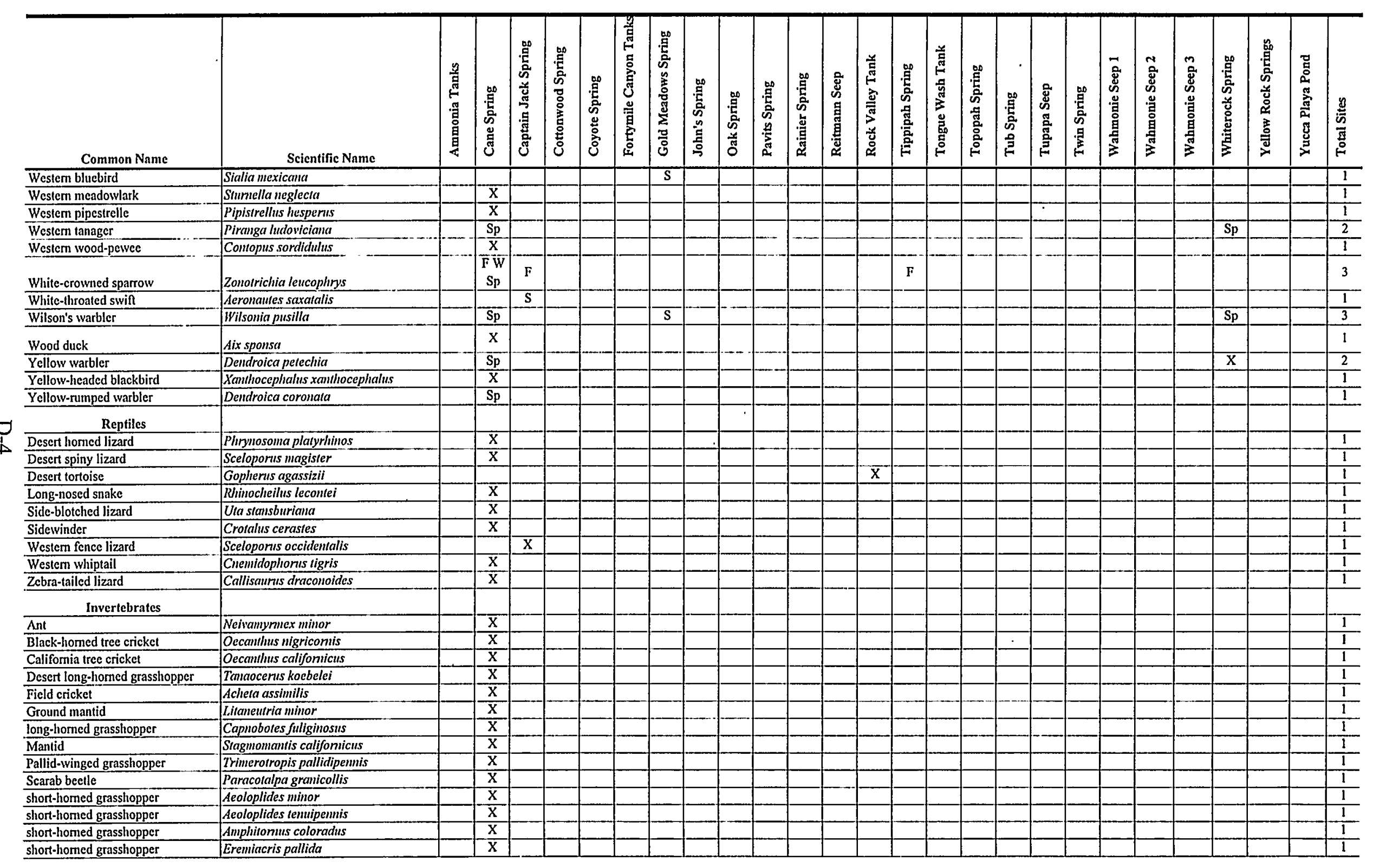

Sources: Allred et al., 1963; Hayward et al., 1963; Jorgensen and Haywood, 1965; Castetter, 1979; Romney and Greger, 1992; Greger and Romney, 1994 a,b; BN, 1996 ; and Bechtel Nevada unpublished field records, 1974 -1997. 


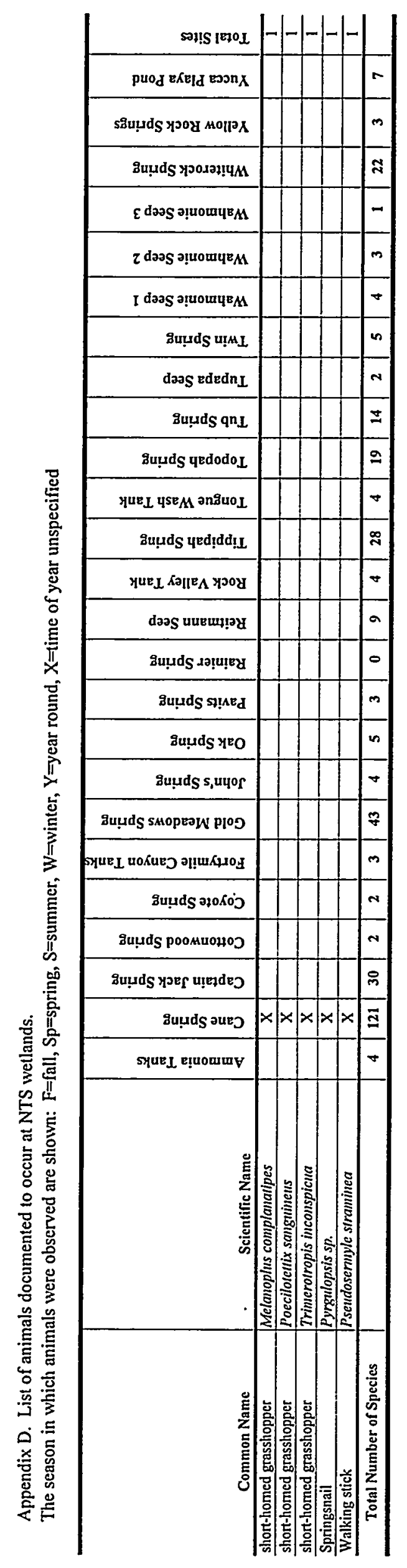

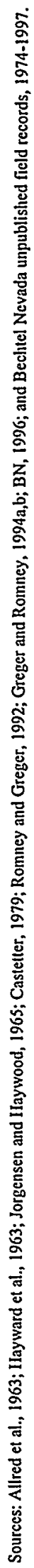


This Page Intentionally Left Blank 


\section{DISTRIBUTION}

U.S. Department of Energy, Nevada Operations Office

Las Vegas. Nevada Leah Dever, AMEM Joe Fiore, AMNS Kennith Hoar, EPD Robert Furlow, EPD Technical Information Resource Center

U.S. Department of Energy, Yucca Mountain Site Characterization Office Las Vegas, Nevada Wendy Dixon (2)

U.S. DOE/HQ

Oak Ridge, Tennessee OSTI

U.S. Army Corps of Engineers

Reno. Nevada

Kevin Rouke

U.S. Bureau of Land Management

Las Vegas, Nevada

Gayle Marrs-Smith

U.S. Fish and Wildlife Service, Suboffice No. 1 Las Vegas Field Office

Las Vegas, Nevada

Dolores Savignano

U.S. Fish and Wildlife Service, Nevada State Office

Reno. Nevada

Carlos Mendoza

Desert National Wildlife Refuge Complex

Las Vegas, Nevada

Kenneth Voget

Death Valley National Park

Death Valley, California

Richard Martin

Nellis Air Force Base

Las Vegas. Nevada Susan Barrow (2)

Nevada Department of Wildlife, Region III Las Vegas, Nevada Mike Wickersham

Ash Meadows National Wildlife Refuge Ash Meadows, Nevada

David Ledig
Bechtel Nevada

Science Projects

North Las Vegas. Nevada Kevin Van Cleave (5)

Defense Special Weapons Agency

Mercury, Nevada .

Laurence Ashbaugh

Desert Research Institute

Las Vegas, Nevada

Roger Jacobson (3)

Harry Reid Center

University of Las Vegas.

Las Vegas, Nevada

Don Baepler

IT Corporation

Las Vegas, Nevada

Mary Lou Brown

Nevada Natural Heritage Program

Carson City. Nevada

James Morefield

Las Vegas Valley Water District

Las Vegas. Nevada

Pat Mulroy

Lawrence Livermore National Laboratory

Las Vegas, Nevada

Willy Cooper

Los Alamos National Laboratory

Las Vegás. Nevada Jim Ogle

Sandia National Laboratory

Las Vegas. Nevada

Larry Posey

The Nature Conservancy

Las Vegas. Nevada

Teri Knight

DOE Office of Scientific and Technical Information

Alexandria, V.irginia (2)

Technical Information Resource Center Las Vegas, Nevada

Bechtel Nevada Public Reading Room

Las Vegas, Nevada 